DOE/EIA-0484(95)

Distribution Category UC-950

\title{
International Energy Outlook
}

1995

\section{May 1995}

Energy Information Administration

Office of Integrated Analysis and Forecasting

U.S. Department of Energy

Washington, DC 20585

This report was prepared by the Energy Information Administration, the independent statistical and analytical agency within the Department of Energy. The information contained herein should not be construed as advocating or reflecting any policy position of the Department of Energy or of any other organization. 


\section{Contacts}

The International Energy Outlook is prepared by the Energy Information Administration (EIA). General questions concerning the contents of the report should be referred to Mary J. Hutzler (202/586-2222), Director, Office of Integrated Analysis and Forecasting; Arthur T. Andersen (202/586-1441), Director, Energy Demand and Integration Division; or Gerald E. Peabody (202/ 586-1458), Chief, International, Economic, and Integrated Forecasting Branch. Specific questions about the report should be referred to Linda E. Doman (202/5861041) or the following analysts:

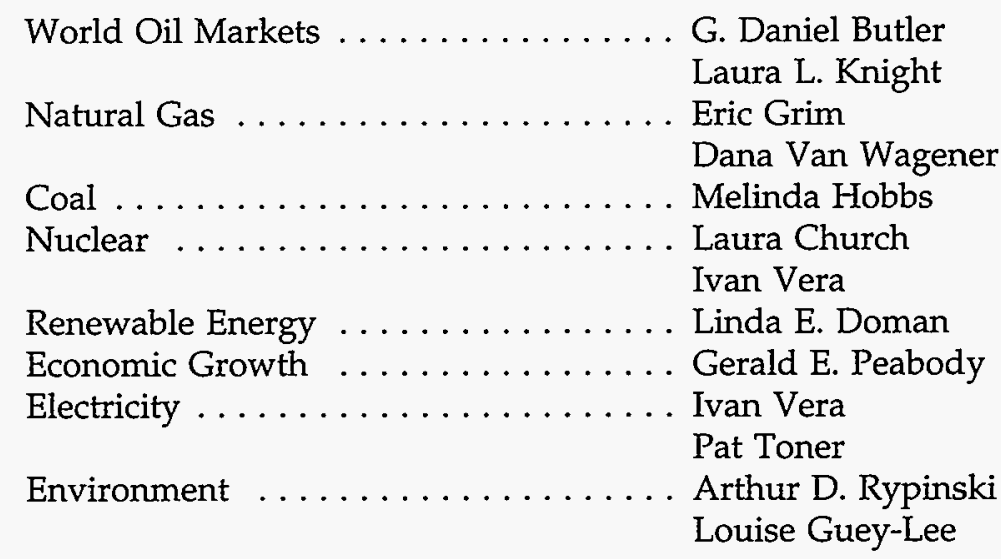

(202/586-9503)

$(202 / 586-4725)$

(202/586-0012)

$(202 / 586-1494)$

(202/586-2276)

(202/586-1041)

(202/586-1458)

(202/586-2276)

(202/586-2048)

(202/586-8425)

(202/586-1156) 


\section{DISCLAIMER}

This report was prepared as an account of work sponsored by an agency of the United States Government. Neither the United States Government nor any agency thereof, nor any of their employees, make any warranty, express or implied, or assumes any legal liability or responsibility for the accuracy, completeness, or usefulness of any information, apparatus, product, or process disclosed, or represents that its use would not infringe privately owned rights. Reference herein to any specific commercial product, process, or service by trade name, trademark, manufacturer, or otherwise does not necessarily constitute or imply its endorsement, recommendation, or favoring by the United States Government or any agency thereof. The views and opinions of authors expressed herein do not necessarily state or reflect those of the United States Government or any agency thereof. 


\section{DISCLAIMER}

Portions of this document may be illegible in electronic image products. Images are produced from the best available original document. 


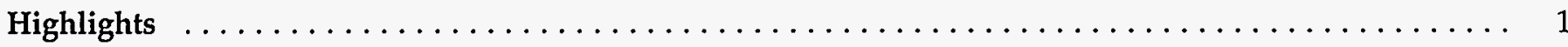

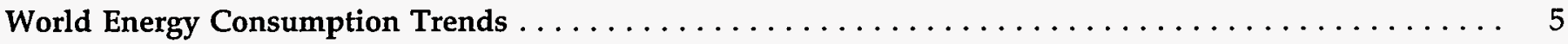

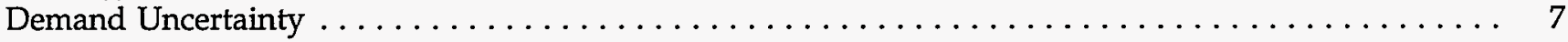

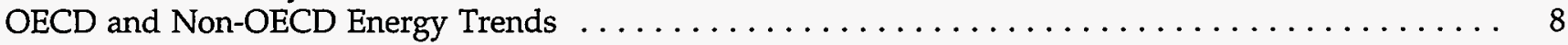

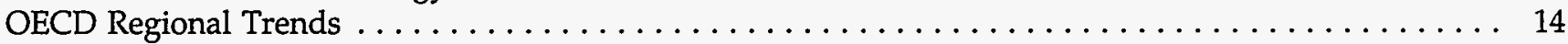

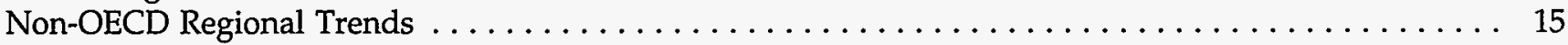

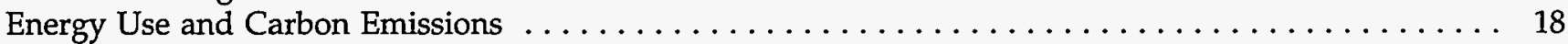

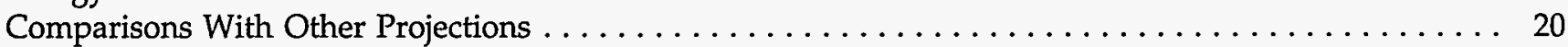

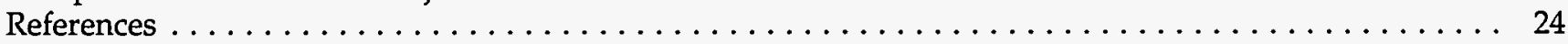

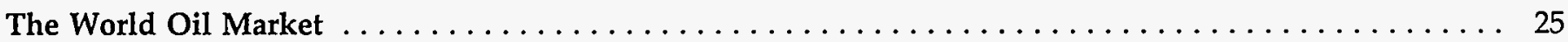

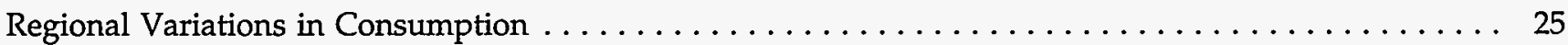

OPEC Reserves and Production Capacity Expansion $\ldots \ldots \ldots \ldots \ldots \ldots \ldots \ldots \ldots \ldots \ldots \ldots \ldots \ldots \ldots \ldots \ldots$

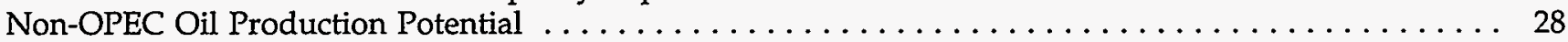

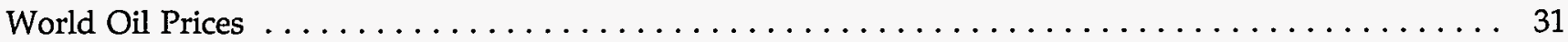

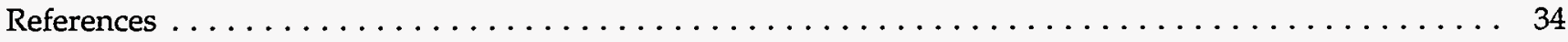

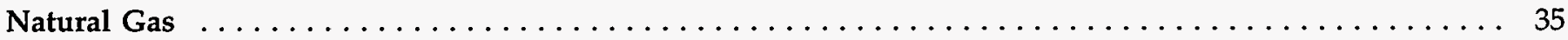

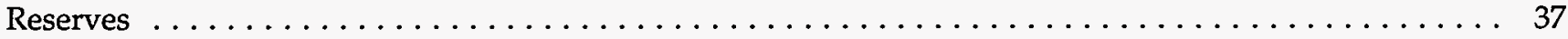

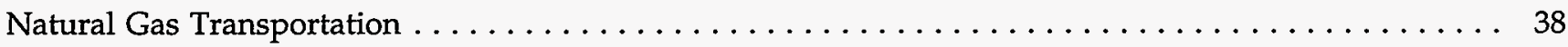

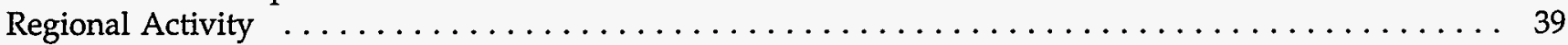

References ..................................... 42

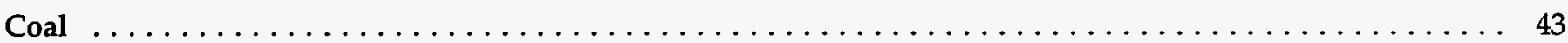

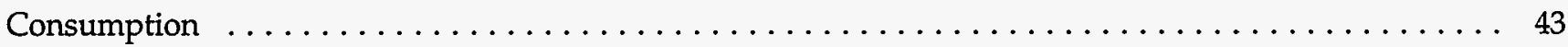

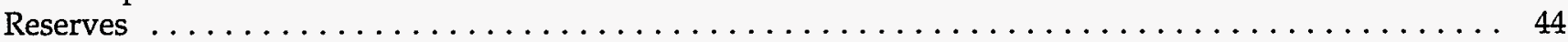

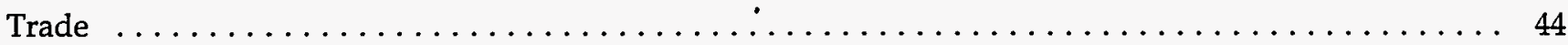

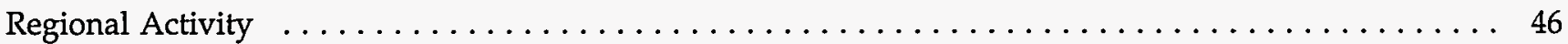

References .................................... 48

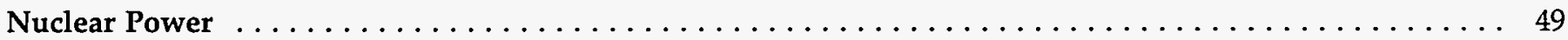

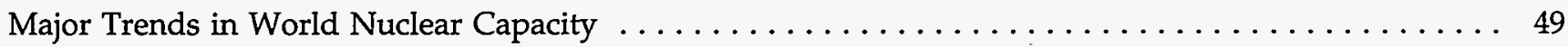

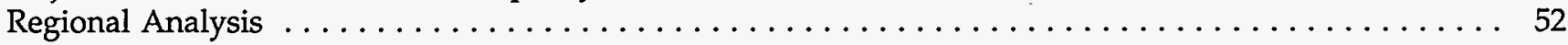

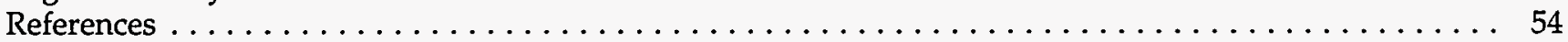

Hydroelectric and Other Renewable Energy $\ldots \ldots \ldots \ldots \ldots \ldots \ldots \ldots \ldots \ldots \ldots \ldots \ldots \ldots \ldots \ldots$

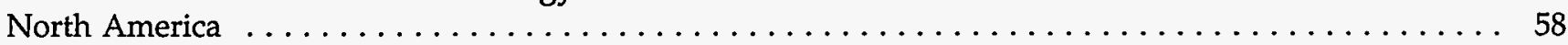

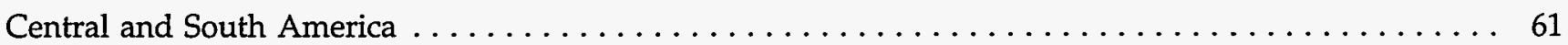

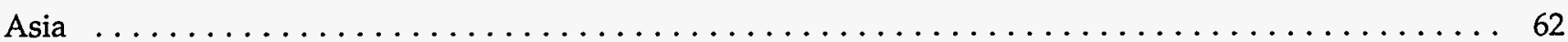

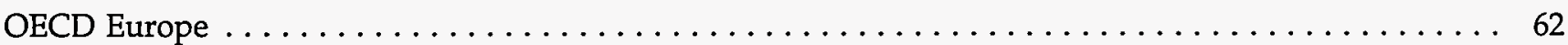

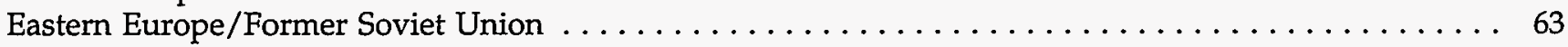

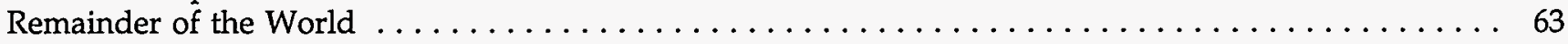

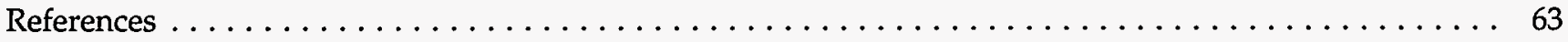




\section{Contents (Continued)}

Page

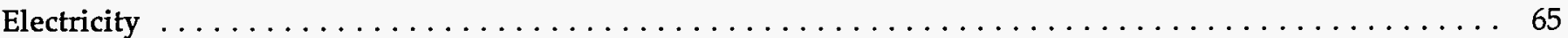

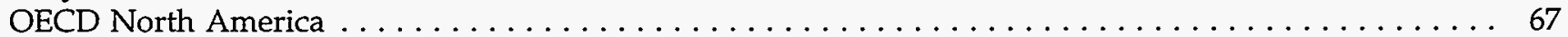

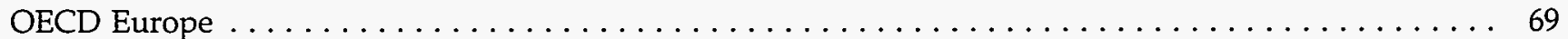

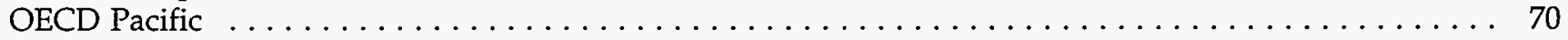

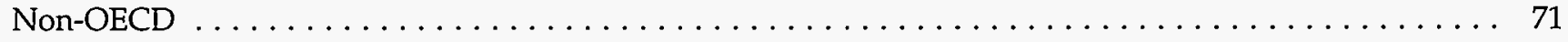

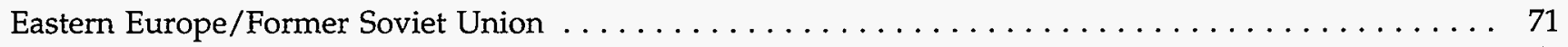

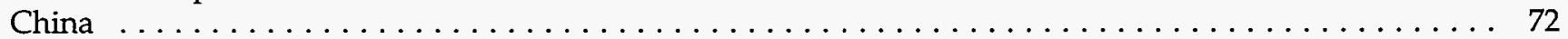

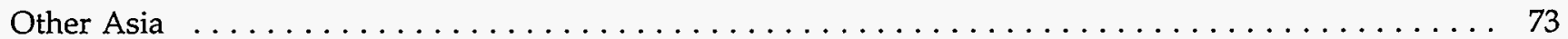

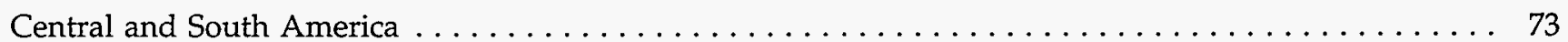

References ........................................... 74

\section{Appendixes}

A. World Energy Consumption and Carbon Emissions Tables $\ldots \ldots \ldots \ldots \ldots \ldots \ldots \ldots \ldots \ldots .79$

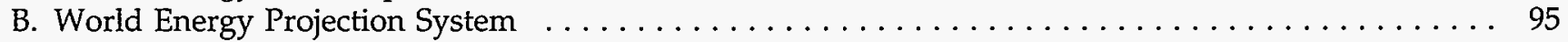




\section{Tables}

Page

1. World Energy Consumption by Fuel, $1970-2010 \ldots \ldots \ldots \ldots \ldots \ldots \ldots \ldots \ldots \ldots \ldots \ldots$

2. Annual Growth Rates in Gross Domestic Product by Region and for Selected Countries, 1970-2010 . . . 7

3. Variation in Energy Consumption in 2010, Given Alternative Assumptions About Energy Intensity .... 8

4. World Energy Consumption by Region and Fuel, $1970-2010 \ldots \ldots \ldots \ldots \ldots \ldots \ldots \ldots \ldots \ldots \ldots$

5. Average Energy Elasticity (Change in Consumption Versus Change in Gross Domestic Product),

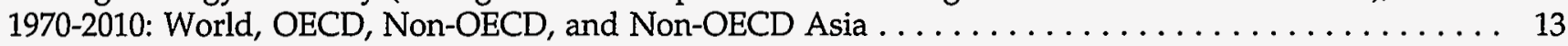

6. OECD Energy Consumption by Region, $1970-2010 \ldots \ldots \ldots \ldots \ldots \ldots \ldots \ldots \ldots \ldots \ldots \ldots \ldots \ldots$

7. Non-OECD Energy Consumption by Region, $1970-2010 \ldots \ldots \ldots \ldots \ldots \ldots \ldots \ldots \ldots \ldots \ldots \ldots$

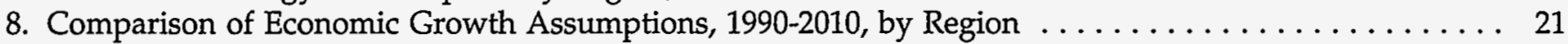

9. Comparison of Energy Consumption Growth Rates, 1990-2010, by Fuel Type . . . . . . . . . . . 22

10. Comparison of World Oil Consumption, Production, and Price Projections, 2000 and 2010, by Region .. 23

11. Reserves and Production Measures for OPEC and Non-OPEC Producers $\ldots \ldots \ldots \ldots \ldots \ldots \ldots \ldots$

12. World Oil Production Capacity Assumptions by Region, $1990-2010$. . . . . . . . . . . . . . . . . . . 29

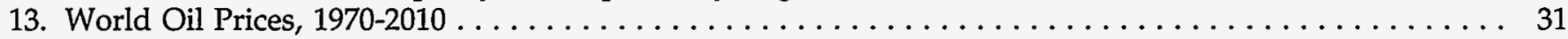

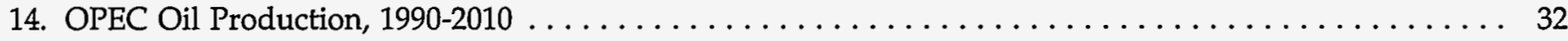

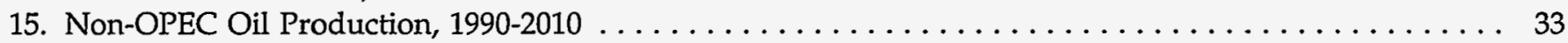

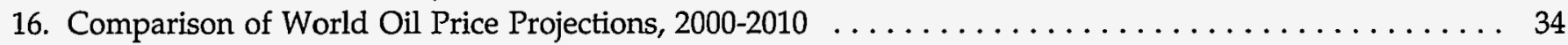

17. Shares of World Natural Gas Consumption by Region, 1990, 2000, and $2010 \ldots \ldots \ldots \ldots \ldots \ldots$

18. World Natural Gas Proven Reserves by Country as of January $1,1995 \ldots \ldots \ldots \ldots \ldots \ldots \ldots \ldots$

19. Historical Estimates of Natural Gas Proven Reserves by Region, $1975-1995 \ldots \ldots \ldots \ldots \ldots \ldots \ldots$

20. World Coal Flows by Importing and Exporting Regions, Reference Case $\ldots \ldots \ldots \ldots \ldots \ldots \ldots \ldots$

21. Historical and Projected Operable Nuclear Capacities $\ldots \ldots \ldots \ldots \ldots \ldots \ldots \ldots \ldots \ldots \ldots \ldots \ldots$

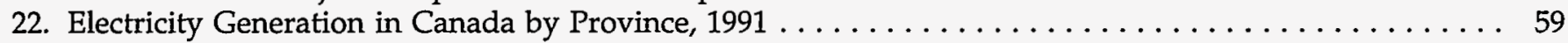

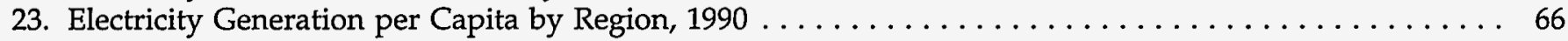

24. World Energy Consumption for Electricity Generation by Region and Fuel, 1990-2010 . . . . . . . 67

A1. World Total Energy Consumption by Region and Fuel, $1990-2010$. . . . . . . . . . . . . . . . 79

A2. World Total Energy Consumption by Region, $1990-2010 \ldots \ldots \ldots \ldots \ldots \ldots \ldots \ldots \ldots \ldots \ldots \ldots$

A3. World Total Oil Consumption by Region, $1990-2010 \ldots \ldots \ldots \ldots \ldots \ldots \ldots \ldots \ldots \ldots \ldots \ldots$

A4. World Total Natural Gas Consumption by Region, $1990-2010 \ldots \ldots \ldots \ldots \ldots \ldots \ldots \ldots \ldots \ldots \ldots$. . . . . 82

A5. World Total Coal Consumption by Region, $1990-2010 \ldots \ldots \ldots \ldots \ldots \ldots \ldots \ldots \ldots \ldots \ldots \ldots$

A6. World Net Nuclear Energy Consumption by Region, $1990-2010$. . . . . . . . . . . . . . . . . 84

A7. World Consumption of Hydroelectricity and Other Renewable Energy by Region, 1990-2010 . . . . . 85

A8. World Total Net Electricity Consumption by Region, $1990-2010$. . . . . . . . . . . . . . . . . 86

A9. World Total Carbon Emissions by Region, $1990-2010 \ldots \ldots \ldots \ldots \ldots \ldots \ldots \ldots \ldots \ldots \ldots \ldots$

A10. World Carbon Emissions From Oil Use by Region, $1990-2010 \ldots \ldots \ldots \ldots \ldots \ldots \ldots \ldots \ldots \ldots \ldots$.

A11. World Carbon Emissions From Natural Gas Use by Region, 1990-2010 . . . . . . . . . . . . . . . . 89

A12. World Carbon Emissions From Coal Use by Region, $1990-2010 \ldots \ldots \ldots \ldots \ldots \ldots \ldots \ldots \ldots \ldots$. . . . 90

A13. World Total Energy Consumption by Region and Fuel, 1990-2010 (Exajoules) . . . . . . . . . . 91

A14. World Total Energy Consumption by Region, 1990-2010 (Exajoules) $\ldots \ldots \ldots \ldots \ldots \ldots \ldots \ldots . . \ldots 2$ 


\section{Figures}

Page

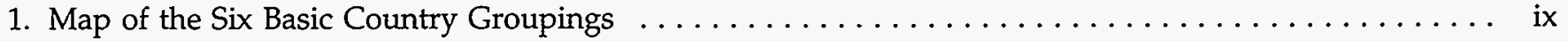

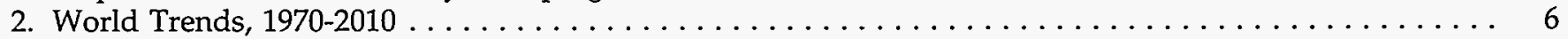

3. World Energy Consumption, 1990 and 2010, Assuming OECD Energy Consumption Rates per Capita .. 6

4. World Oil Price Ranges, $1970-2010 \ldots \ldots \ldots \ldots \ldots \ldots \ldots \ldots \ldots \ldots \ldots \ldots \ldots \ldots \ldots$

5. OECD and Non-OECD Energy Consumption, $1970-2010 \ldots \ldots \ldots \ldots \ldots \ldots \ldots \ldots \ldots \ldots \ldots \ldots$

6. Total World Energy Consumption, $1970-2010 \ldots \ldots \ldots \ldots \ldots \ldots \ldots \ldots \ldots \ldots \ldots \ldots$

7. OECD Energy Consumption by Fuel Type, $1970-2010 \ldots \ldots \ldots \ldots \ldots \ldots \ldots \ldots \ldots \ldots \ldots \ldots$

8. Non-OECD Energy Consumption by Fuel Type, $1970-2010 \ldots \ldots \ldots \ldots \ldots \ldots \ldots \ldots \ldots \ldots \ldots \ldots$

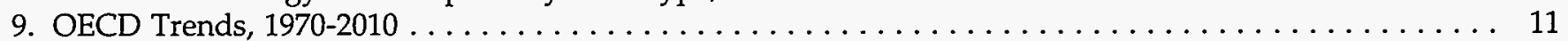

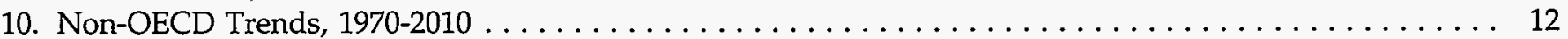

11. World Energy Intensities, OECD and Non-OECD, $1970-2010 \ldots \ldots \ldots \ldots \ldots \ldots \ldots \ldots \ldots \ldots \ldots$

12. Non-OECD Electricity Consumption by Region, $1970-2010 \ldots \ldots \ldots \ldots \ldots \ldots \ldots \ldots \ldots \ldots \ldots \ldots$

13. World Population by Region, $1970-2010 \ldots \ldots \ldots \ldots \ldots \ldots \ldots \ldots \ldots \ldots \ldots \ldots \ldots \ldots$

14. OECD and Non-OECD Energy Consumption per Capita, $1970-2010 \ldots \ldots \ldots \ldots \ldots \ldots \ldots \ldots$.

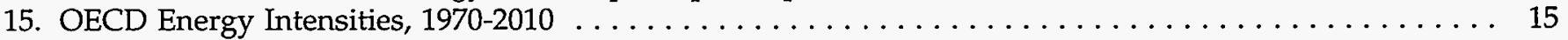

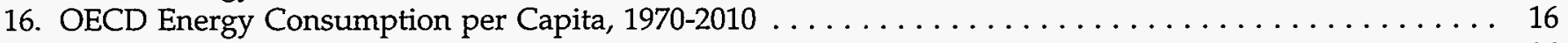

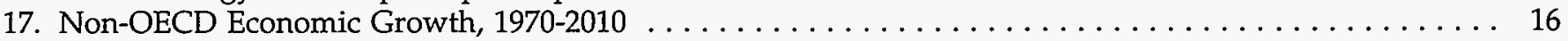

18. Non-OECD Energy Consumption by Region, $1970-2010 \ldots \ldots \ldots \ldots \ldots \ldots \ldots \ldots \ldots \ldots \ldots$

19. Non-OECD Energy Intensities by Region, $1970-2010 \ldots \ldots \ldots \ldots \ldots \ldots \ldots \ldots \ldots \ldots \ldots \ldots \ldots$

20. Non-OECD Energy Consumption per Capita, $1970-2010 \ldots \ldots \ldots \ldots \ldots \ldots \ldots \ldots \ldots \ldots \ldots \ldots$

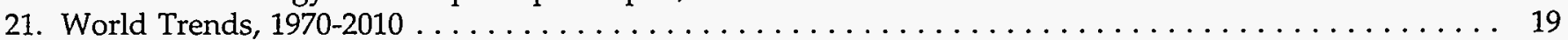

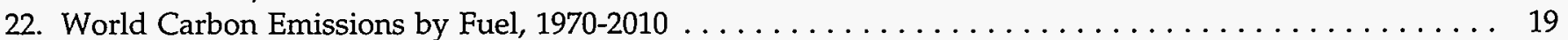

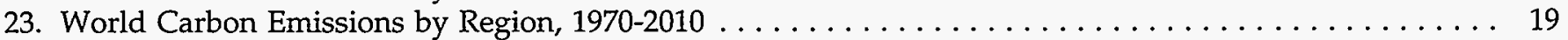

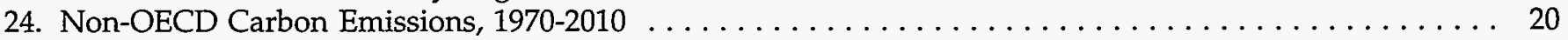

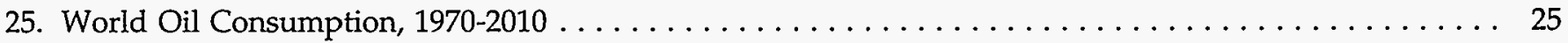

26. World Oil Consumption Relative to All Other Energy Sources, $1970-2010 \ldots \ldots \ldots \ldots \ldots \ldots \ldots \ldots .25$

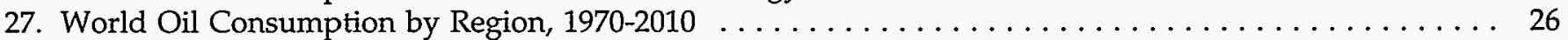

28. Additions of Crude Oil Proven Reserves by Decade, $1960-1990 \ldots \ldots \ldots \ldots \ldots \ldots \ldots \ldots \ldots \ldots \ldots 27$

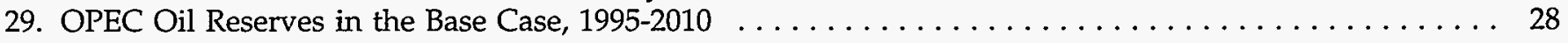

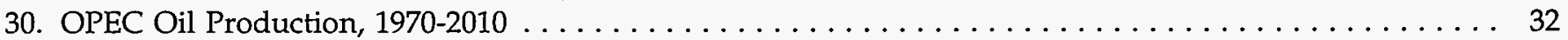

31. World Consumption of Natural Gas, $1970-2010 \ldots \ldots \ldots \ldots \ldots \ldots \ldots \ldots \ldots \ldots \ldots \ldots \ldots \ldots$

32. World Consumption of Natural Gas Relative to All Other Energy Sources, 1970-2010 . . . . . . . . . 36

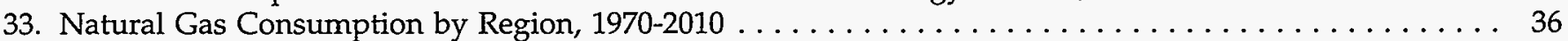

34. World Natural Gas Proven Reserves by Region, as of January $1,1995 \ldots \ldots \ldots \ldots \ldots \ldots \ldots \ldots$

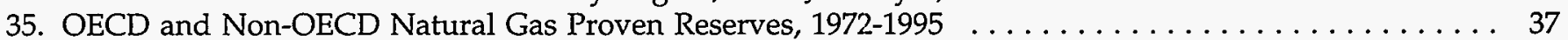

36. World Coal Consumption, $1970-2010 \ldots \ldots \ldots \ldots \ldots \ldots \ldots \ldots \ldots \ldots \ldots \ldots \ldots \ldots$

37. World Consumption of Coal Relative to All Other Energy Sources, $1970-2010 \ldots \ldots \ldots \ldots$. . . . . . 43

38. World Coal Consumption by Region, $1970-2010 \ldots \ldots \ldots \ldots \ldots \ldots \ldots \ldots \ldots \ldots \ldots \ldots \ldots \ldots$

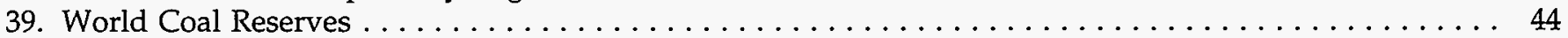

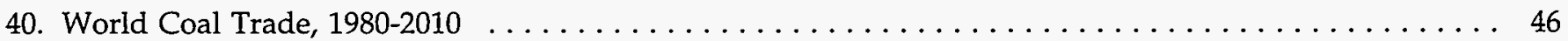

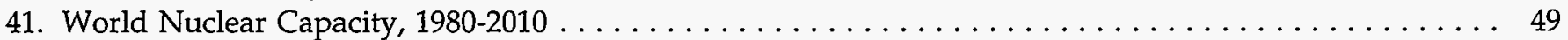

42. World Nuclear Capacity by Region, $1970-2010 \ldots \ldots \ldots \ldots \ldots \ldots \ldots \ldots \ldots \ldots \ldots \ldots \ldots \ldots . \ldots \ldots$

43. World Consumption of Electricity From Nuclear Power Relative to All Other Fuels, 1970-2010 . . . . . 51

44. World Consumption of Hydroelectricity and Other Renewables, 1970-2010 . . . . . . . . . . . 57

45. World Consumption of Hydroelectricity and Other Renewables Relative to All Other Fuels, 1970-2010 . 57

46. World Consumption of Hydroelectricity and Other Renewables by Region, 1970-2010 . . . . . . . 58

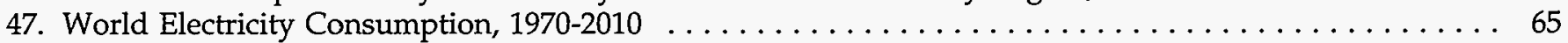

48. World Electricity Consumption by Generating Fuel Type, 1990 and $2010 \ldots \ldots \ldots \ldots \ldots$ 


\section{IEO95 presents historical data from 1970 to 1990, and EIA's projections of energy consumption and carbon emissions through 2010, for six country groups. Prospects for individual fuels are discussed.}

The International Energy Outlook 1995 (IEO95) presents an assessment by the Energy Information Administration (EIA) of the international energy market outlook through 2010. The report is an extension of the EIA's Annual Energy Outlook 1995 (AEO95), which was prepared using the National Energy Modeling System (NEMS). U.S. projections appearing in the IEO95 are consistent with those published in the AEO95. IEO95 is provided as a statistical service to energy managers and analysts, both in government and in the private sector. The projections are used by international agencies, Federal and State governments, trade associations, and other planners and decisionmakers. They are published pursuant to the Department of Energy Organization Act of 1977 (Public Law 95-91), Section 205(c). The IEO95 projections are based on U.S. and foreign government policies in effect on October 1, 1994.

IEO95 displays projections according to six basic country groupings (Figure 1). The regionalization has changed since last year's report. Mexico has been added to the Organization for Economic Cooperation and Development (OECD), and a more detailed regionalization has been incorporated for the remainder of the world, including the following subgroups: non-OECD Asia, Africa, Middle East, and Central and South America. China is included in non-OECD Asia. Eastern Europe and the former Soviet Union are combined in the EE/FSU subgroup.

The report begins with a look at the worldwide trends associated with energy consumption. The historical time frame has been expanded from previous reports to incorporate data from 1970. The longer time span provides readers with a better historical context for the projections. The environment remains an important focus internationally as nations attempt to stabilize carbon emissions at their 1990 levels as agreed upon at the June 1992 United Nations Conference on the Environment and Development, held in Rio de Janeiro, Brazil. World carbon emissions attributable to fossil fuels (oil, natural gas, and coal) were computed as part of EIA's international model, the World Energy Projection System (WEPS), which is described in Appendix $B$ of this report. As is true for energy consumption, the time frame for carbon emissions includes historical data from 1970.
The remainder of the report is organized by energy source. Regional consumption projections for oil, natural gas, coal, nuclear power, hydroelectric and other renewable energy (geothermal, solar, biomass, wind, and other renewable sources), and electricity are discussed. Several chapters feature discussions on North America, important regionally because of Mexico's acceptance into the OECD and because of the potential impact of the recent North American Free Trade Agreement.

Summary tables of the IEO95 world energy consumption projections are provided in Appendix A. The Reference Case projections of total foreign energy consumption and of natural gas, coal, and renewable energy were prepared using WEPS. Reference Case projections of foreign oil production and consumption were prepared using the International Energy Module of NEMS. Nuclear consumption projections were derived from the International Nuclear Model, PC Version (PC-INM). Alternatively, nuclear capacity projections were developed using two methods: the Lower Reference Case projections were based on analysts' knowledge of the nuclear programs in different countries; the Upper Reference Case was generated by the World Integrated Nuclear Evaluation System (WINES)-a demand-driven model. In addition, the NEMS Coal Export Submodule (CES) was used to derive flows in international coal trade.

Projections of world electricity consumption are new to IEO95. Electricity is undergoing fast-paced growth, particularly in Asia, where the economies of such nations as China, South Korea, and Taiwan are rapidly expanding. Reference Case projections of foreign electricity consumption were prepared using the WEPS.

Unlike the AEO95, this report does not present a set of alternative cases. Instead, a range of sensitivities has been constructed for the energy consumption projections, relative to the IEO95 Reference Case estimates. Two cases derived from the International Energy Module represent the oil range, and two cases derived from the PCINM represent the nuclear consumption range. The sensitivity range for total energy is calculated by altering assumptions about economic growth and energy intensity. Sensitivity ranges for 
natural gas, coal, and other energy consumption are calculated from the ranges for total energy consumption and those for oil and nuclear energy. Electricity consumption ranges are constructed according to the ranges for total energy consumption. Sensitivity ranges are also provided for total carbon emissions and for carbon emissions from the combustion of different fossil fuels (oil, natural gas, and coal). The emissions ranges are computed to agree with the consumption ranges for the respective fuels.

Figure 1. Map of the Six Basic Country Groupings

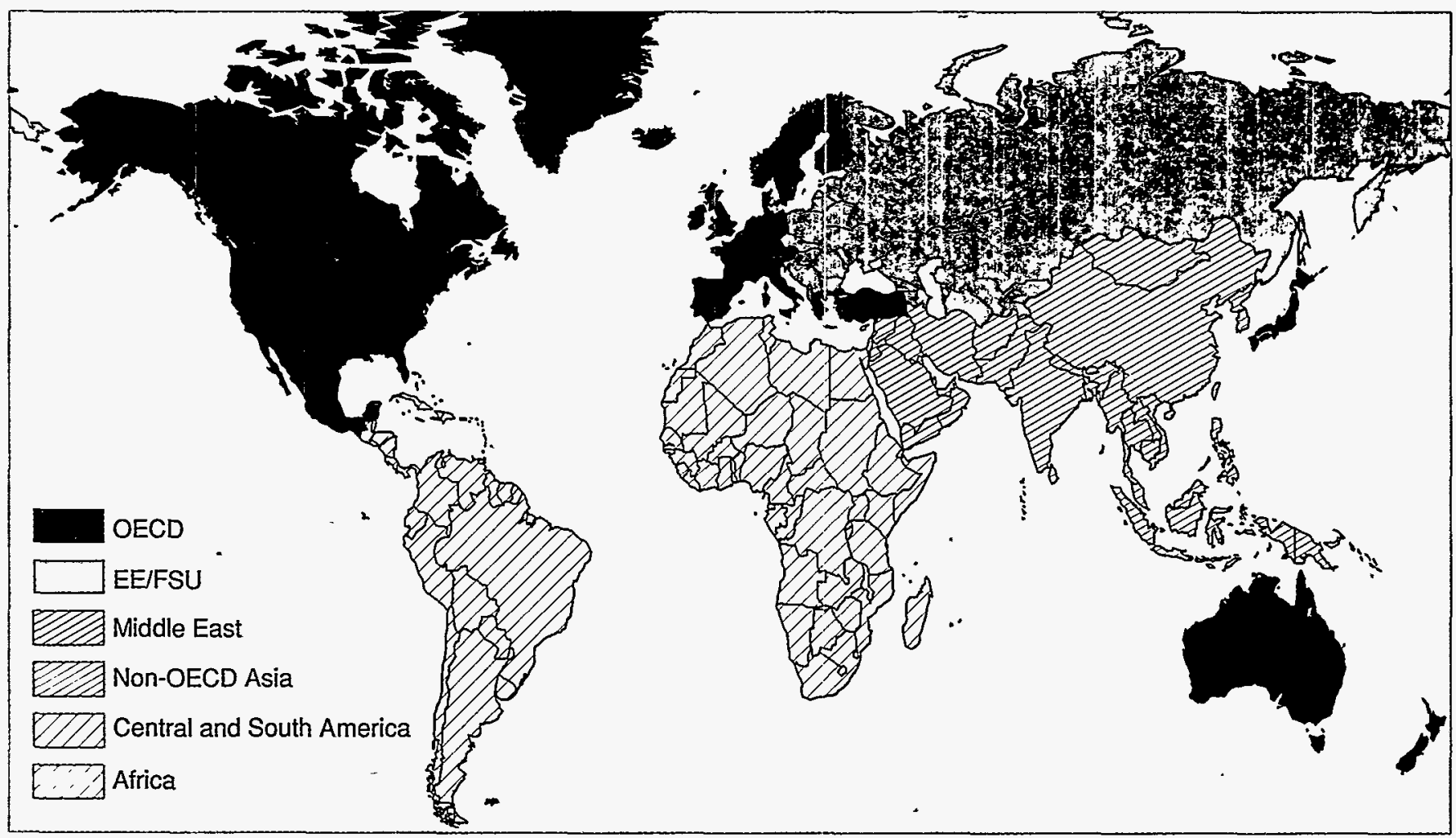

Source: Energy Information Administration, Office of Integrated Analysis and Forecasting.

The six basic country groupings used in this report (Figure 1) are defined as follows:

- Organization for Economic Cooperation and Development (OECD): Australia, Austria, Belgium, Canada, Denmark, Finland, France, Germany, Greece, Iceland, Ireland, Italy, Japan, Luxembourg, Mexico, the Netherlands, New Zealand, Norway, Portugal, Spain, Sweden, Switzerland, Turkey, the United Kingdom, and the United States. The OECD countries contain 17 percent of the 1994 world population.
- Eastern Europe and the former Soviet Union (EE/FSU) (7 percent of the 1994 world population):

- Eastern Europe: Albania, Bulgaria, Czech Republic, Hungary, Poland, Romania, Slovakia, and former Yugoslavia.

- Former Soviet Union (FSU): The Baltic States of Estonia, Latvia, and Lithuania, as well as Armenia, Azerbaijan, Belarus, Georgia, Kazakhstan, Kyrgyzstan, Moldova, Russia, Tajikistan, Turkmenistan, Ukraine, and Uzbekistan. 
- Non-OECD Asia (53 percent of the 1994 world population): Afghanistan, Bangladesh, Bhutan, Brunei, Cambodia (Kampuchea), China, Fiji, French Polynesia, Hong Kong, India, Indonesia, Kiribatia, Laos, Malaysia, Macau, Maldives, Mongolia, Myanmar (Burma), Nauru, Nepal, New Caledonia, Niue, North Korea, Pakistan, Papua New Guinea, Philippines, Singapore, Solomon Islands, South Korea, Sri Lanka, Taiwan, Thailand, Tonga, Vanuatu, Vietnam, and Western Samoa.

- Middle East (2 percent of the 1994 world population): Bahrain, Cyprus, Iran, Iraq, Israel, Jordan, Kuwait, Lebanon, Oman, Qatar, Saudi Arabia, Syria, the United Arab Emirates, and Yemen.

- Africa (13 percent of the 1994 world population): Algeria, Angola, Benin, Botswana, Burkina Faso, Burundi, Cameroon, Cape Verde, Central African Republic, Chad, Comoros, Congo, Djibouti, Egypt, Equatorial Guinea, Ethiopia, Gabon, Gambia, Ghana, Guinea, Guinea-Bissau, Ivory Coast, Kenya, Lesotho, Liberia, Libya, Madagascar, Malawi, Mali, Mauritania, Mauritius, Morocco, Mozambique, Namibia, Niger, Nigeria, Reunion, Rwanda, Sao Tome and Principe, Senegal, Seychelles, Sierra Leone, Somalia, South Africa, St. Helena, Sudan, Swaziland, Tanzania, Togo, Tunisia, Uganda, Western Sahara, Zaire, Zambia, and Zimbabwe.
- Central and South America (7 percent of the 1994 world population): Antarctic Fisheries, Antigua and Barbuda, Argentina, Aruba, Bahama Islands, Barbados, Belize, Bolivia, Brazil, British Virgin Islands, Cayman Islands, Chile, Colombia, Costa Rica, Cuba, Dominica, Dominican Republic, Ecuador, El Salvador, Falkland Islands, French Guiana, Grenada, Guadeloupe, Guatemala, Guyana, Haiti, Honduras, Jamaica, Martinique, Montserrat, Netherlands Antilles, Nicaragua, Panama Republic, Paraguay, Peru, St. Kitts-Nevis, St. Lucia, St. Vincent/Grenadines, Suriname, Trinidad and Tobago, Uruguay, and Venezuela.

In addition, the following commonly used country groupings are referenced in this report:

- Pacific Rim Developing Countries: Hong Kong, Indonesia, Malaysia, Philippines, Singapore, South Korea, Taiwan, and Thailand.

- G-7 Countries: United States, Japan, Canada, United Kingdom, France, Germany, and Italy.

- Organization of Petroleum Exporting Countries (OPEC): Algeria, Gabon, Indonesia, Iran, Iraq, Kuwait, Libya, Nigeria, Qatar, Saudi Arabia, the United Arab Emirates, and Venezuela.

- Persian Gulf: Bahrain, Iran, Iraq, Kuwait, Qatar, Saudi Arabia, and the United Arab Emirates. 


\section{Highlights}

\section{World energy consumption is projected to grow by 1.6 percent per year from 1990 through 2010, with the fastest growth expected for non-OECD Asia. By 2010, OPEC could account for more than half the world's oil supply.}

World energy consumption is projected to increase from 346 quadrillion British thermal units (Btu) to 472 quadrillion Btu between 1990 and 2010, an increase of 1.6 percent annually (Figure H1). The projected growth in total energy consumption is much lower than the 2.6-percent annual growth rate of the previous two decades (1970-1990), reflecting the adoption of more energy-efficient technologies worldwide. More than one-third of the total increase of 125 quadrillion Btu is expected to be provided by oil, mainly because of rapid expansion of the transportation sectors in developing countries. With fossil fuel costs remaining competitive, the growth rate for world oil consumption from 1990 through 2010 is projected to be 1.5 percent per yearonly slightly lower than its 1.6-percent annual growth rate from 1970 through 1990.

\section{Figure H1. Total World Energy Consumption, 1970-2010}

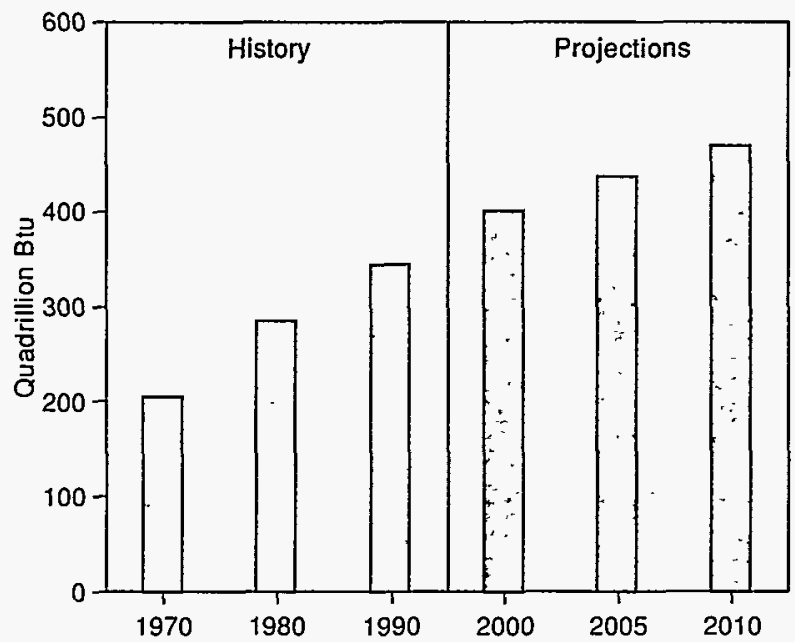

Sources: History: 1970-1979: Energy Information Administration (EIA), Office of Energy Markets and End Use, International Statistics Database. 1980-1992: EIA, International Energy Annual 1992, DOEI EIA-0219(92) (Washington, DC, January 1994). Projections: EIA, World Energy Projection System (1995).

Natural gas and renewable energy sources (hydroelectricity, geothermal, solar, wind, and other renewable resources) are expected to be the fastest growing energy sources over the projection period, at 2.0 and 2.3 percent per year, respectively. The increase in natural gas use reflects efforts to reduce pollution and carbon emissions by switching to cleaner fuels. Growing support for research on renewable energy technologies in the countries of the Organization for Economic Cooperation and Development (OECD) and rising demand for electric power in non-OECD countries are the principal factors underlying the rapid growth of renewable energy use in the forecast.

Energy consumption in the OECD region is expected to grow by 1.3 percent annually from 1990 through 2010 . This growth rate is slightly lower than the rate for the previous two decades, reflecting the implementation of more efficient technologies. Higher economic growth in the rapidly developing non-OECD countries-particularly in Asia-is expected to lead to higher growth in energy demand in those nations. Energy consumption in the non-OECD region as a whole is expected to grow by 1.8 percent annually over the projection period. As a result, non-OECD energy consumption approaches that of the OECD, and by 2010 non-OECD consumers account for almost 50 percent of the total world energy consumption (Figure $\mathrm{H} 2$ ).

Figure H2. OECD and Non-OECD Energy Consumption, 1970-2010

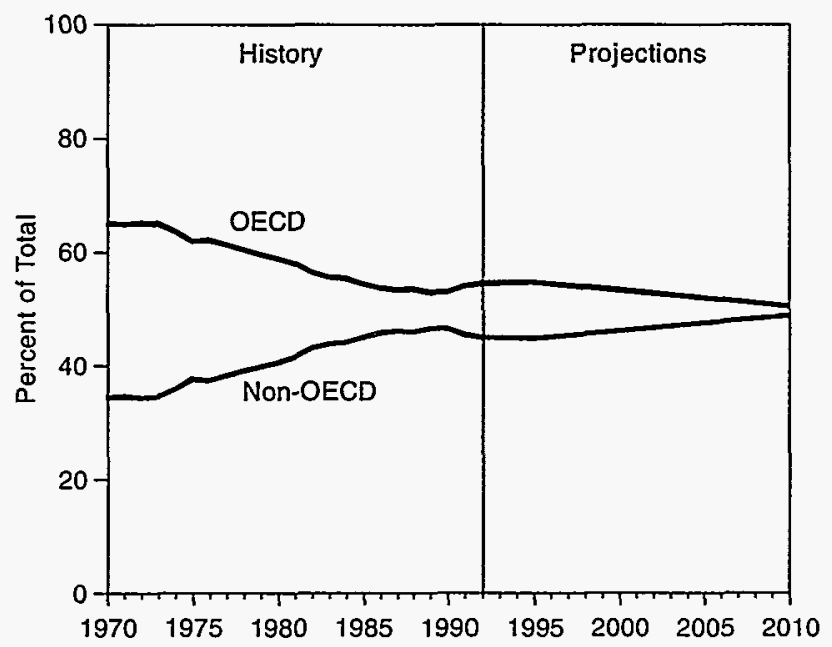

Sources: History: 1970-1979: Energy Information Administration (EIA), Office of Energy Markets and End Use, International Statistics Database. 1980-1992: ElA, International Energy Annual 1992, DOE/ EIA-0219(92) (Washington, DC, January 1994). Projections: EIA, World Energy Projection System (1995). 
The largest gains in energy consumption are expected in the non-OECD Asia region, led by countries with rapid economic growth, such as China and India. China, which has pursued aggressive policies to encourage economic development, could experience the world's fastest growth in energy consumption over the next two decades. In its efforts to modernize, China has continued to shift economic decisionmaking away from central planning and toward the marketplace. The result has been impressive economic growth, which is expected to continue through 2010 , although at a somewhat slower rate than in recent years.

In contrast to the fast-paced growth of energy consumption projected for non-OECD Asia, little or no net growth is expected from 1990 through 2010 in the countries of Eastern Europe (EE) and the former Soviet Union (FSU) (Figure H3), where there have been dramatic economic declines since 1990. Indeed, the EE/ FSU countries are currently consuming less energy than they did in 1990, and they might actually still be consuming less energy in 2005 than they did in 1990. The projections in this report assume that efforts at institutional reforms in the EE/FSU region will be successful in time, and that more normal economic growth and energy consumption will resume by the end of the projection period.

\section{Figure H3. Non-OECD Energy Consumption by Region, 1970-2010}

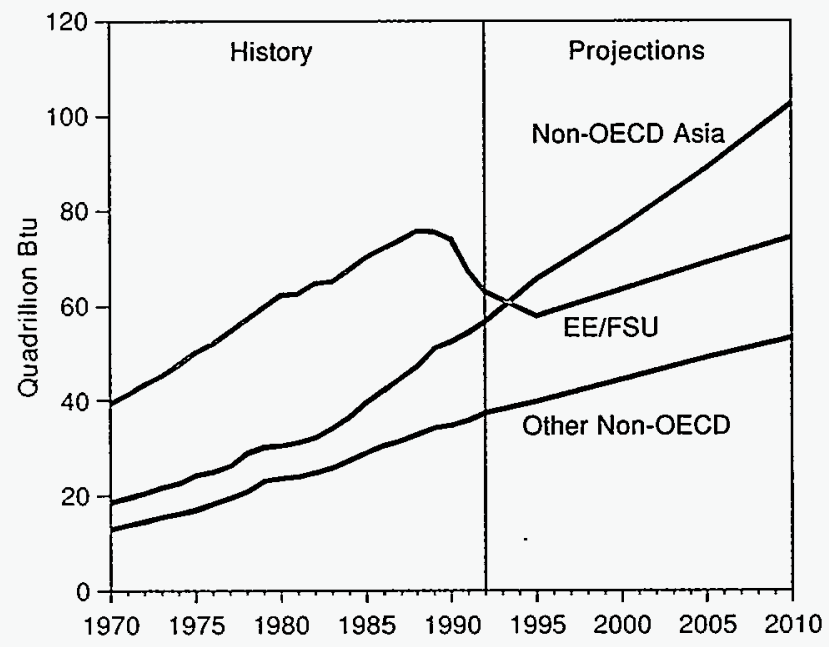

Sources: History: 1970-1979: Energy Information Administration (EIA), Office of Energy Markets and End Use, International Statistics Database. 1980-1992: EIA, International Energy Annual 1992, DOE/ EIA-0219(92) (Washington, DC, January 1994). Projections: EIA, World Energy Projection System (1995).

The world oil price has declined in recent years, and in real terms it is currently near its 1970 level (Figure H4).
The combination of enhanced oil production capacity, end-use technologies that are more fuel-efficient, and shifts from oil to alternative energy sources has resulted in strong downward pressure on prices, even though worldwide demand for oil has continued to increase. Prices are expected-absent any major political event that would affect oil markets-to remain stable for the next few years and then to rise gradually, remaining below $\$ 25$ per barrel (in 1993 U.S. dollars) through the end of the projection period.

\section{Figure H4. World Oil Price Ranges, 1970-2010}

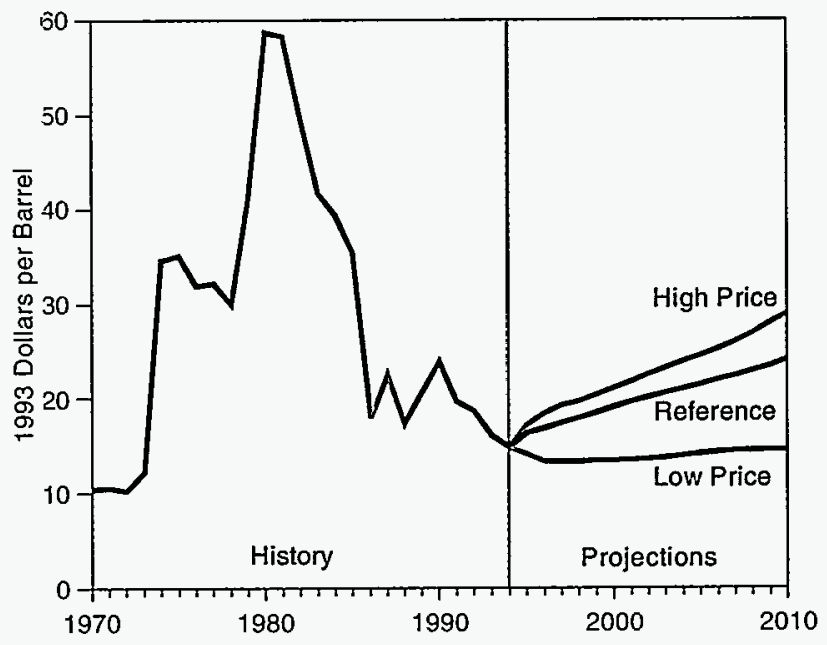

Sources: History: Energy Information Administration (EIA), Annual Energy Review 1993, DOE/EIA-0384(93) (Washington, DC, July 1994). Projections: ElA, Annual Energy Outlook 1995, National Energy Modeling System runs LWOP95.D1103941, AEO95B.D1103942, and HWOP95.D1103942.

The countries of the Organization of Petroleum Exporting Countries (OPEC) are expected to increase oil production by about 21 million barrels per day by 2010 to meet most of the anticipated increase in demand. This substantial production increase contrasts with a much smaller increase (less than 1 million barrels per day) in non-OPEC oil production. By 2010, OPEC could easily account for more than half the world's oil supply, despite efforts by OECD countries to reduce their dependence on OPEC oil. Prospects for oil production in the FSU-a major source of oil outside OPECremain uncertain. In the FSU, crude oil production fell from a high of 12 million barrels per day in 1983 to a low of 7 million barrels per day at the end of 1994.

Oil's share of total world energy consumption is expected to remain fairly stable - at around 39 percent of total primary energy consumption-throughout the projection period, despite falling world oil prices in recent years (Figure H5). After the mid-1970s and early 1980s, 
Figure H5. World Energy Consumption Shares by Source, $1970-2010$

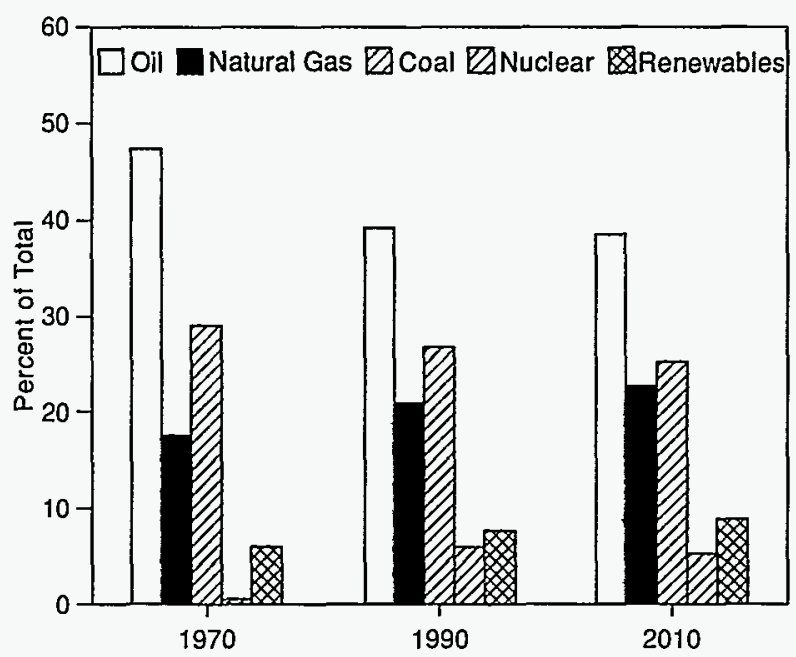

Sources: History: 1970-1979: Energy Information Administration (EIA), Office of Energy Markets and End Use, International Statistics Database. 1980-1992: ElA, International Energy Annual 1992, DOEI EIA-0219(92) (Washington, DC, January 1994). Projections: EIA, World Energy Projection System (1995).

when oil consumption dropped as a result of the 1973 OPEC oil embargo and the 1979 oil price shock, oil use has increased steadily since the mid-1980s. This trend is expected to continue throughout the projection period as oil prices remain competitive.

In contrast to oil, the natural gas share of total world energy consumption is expected to rise from 21 to 23 percent between 1990 and 2010. Abundant reserves and concerns about environmental protection are expected to increase the importance of natural gas as an energy source. Among the fossil fuels (oil, natural gas, and coal), worldwide consumption of natural gas is projected to grow the fastest, at 2 percent per year through 2010 (Figure H6).

Environmental concerns about the air pollutants created by the combustion of coal have contributed to the expectation that coal's share of total energy consumption will decline somewhat, from 27 to 25 percent between 1990 and 2010 (Figure H5). Although coal is expected to remain the second largest energy source worldwide, natural gas is expected to gain, coming within 2 percentage points of coal in its share of total energy consumption in 2010. Coal is expected to remain a major energy source for baseload electric power generation in the future, particularly as oil and natural gas prices rise and as "clean coal technology" advances.
The nuclear power share of total world energy also declines slightly, from 6 to 5 percent, over the projection period. Nuclear power is projected to grow by only 0.2 percent annually from 1990 through 2010 (Figure H5), mainly because of economic concerns, safety issues, and the problems associated with the disposal of nuclear waste. However, countries such as France and Japan, with few indigenous natural resources to exploit, are expected to maintain their strong nuclear programs. Most of the future growth in nuclear power is projected for non-OECD Asia, particularly in South Korea, Taiwan, India, and China.

\section{Figure H6. World Energy Consumption by Primary Energy Source, 1970-2010}

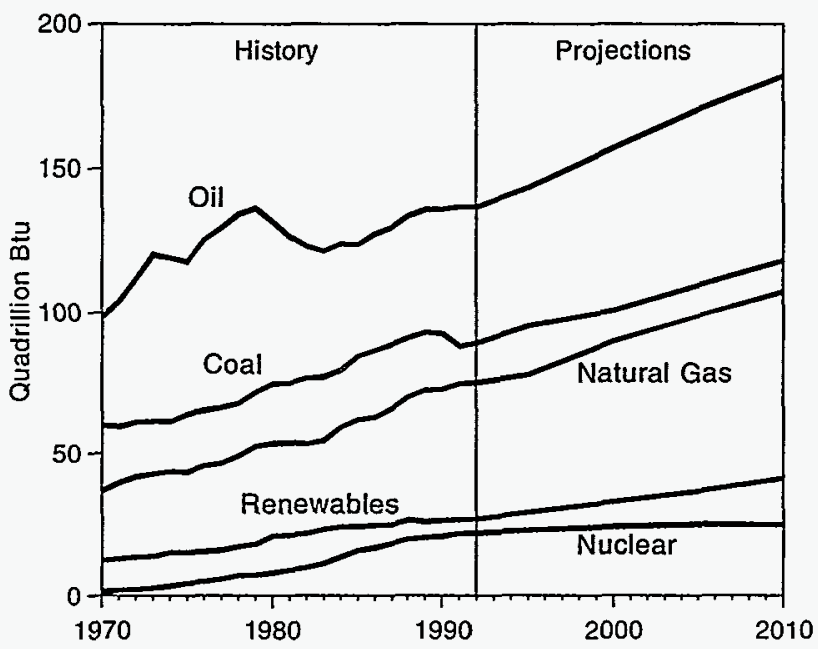

Sources: History: 1970-1979: Energy Information Administration (EIA), Office of Energy Markets and End Use, International Statistics Database. 1980-1992: EIA, International Energy Annual 1992, DOEI EIA-0219(92) (Washington, DC, January 1994). Projections: EIA, World Energy Projection System (1995).

Consumption of hydroelectricity and other renewable sources is expected to grow faster than the consumption of any other primary energy source from 1990 through 2010, by 2.3 percent annually (Figure H6), compared with 1.6-percent annual growth in overall energy consumption. Growing electricity demand among the developing, non-OECD countries is expected to contribute to the growth in the use of renewables. Nevertheless, the abundant supply and competitive cost of fossil fuels are expected to keep renewable energy sources from making substantial gains in terms of the worldwide share of energy consumption.

Electricity is expected to remain the fastest growing form of end-use energy worldwide. Electricity con- 
sumption is projected to grow by 2 percent annually between 1990 and 2010, much of it in the non-OECD countries that are experiencing rapid economic expansion, such as China, South Korea, Indonesia, Singapore, Thailand, Philippines, and Taiwan. Growing world dependence on electricity is expected to result in dramatic changes in the electric power industry around the globe, including regulatory changes leading to the elimination of monopolies and a reduction in government intervention.

Carbon emissions are expected to grow to more than 8 billion metric tons by 2010, representing an annual growth rate of 1.5 percent during the projection period. From the 1970s through the 1980s, the industrialized countries of the OECD accounted for the majority of the world's carbon emissions (Figure H7). The share of emissions attributed to the non-OECD countries began to gain on the OECD share in the mid-1980s, but the collapse of the EE/FSU economies interrupted the trend, as both energy consumption and carbon emissions in the EE/FSU countries dropped sharply. With the recovery of those economies, energy consumption should rise; however, the rate of increase in their carbon emissions may be slowed if their industries are rebuilt with competitive technologies.
Figure H7. OECD and Non-OECD Carbon Emissions, 1970-2010

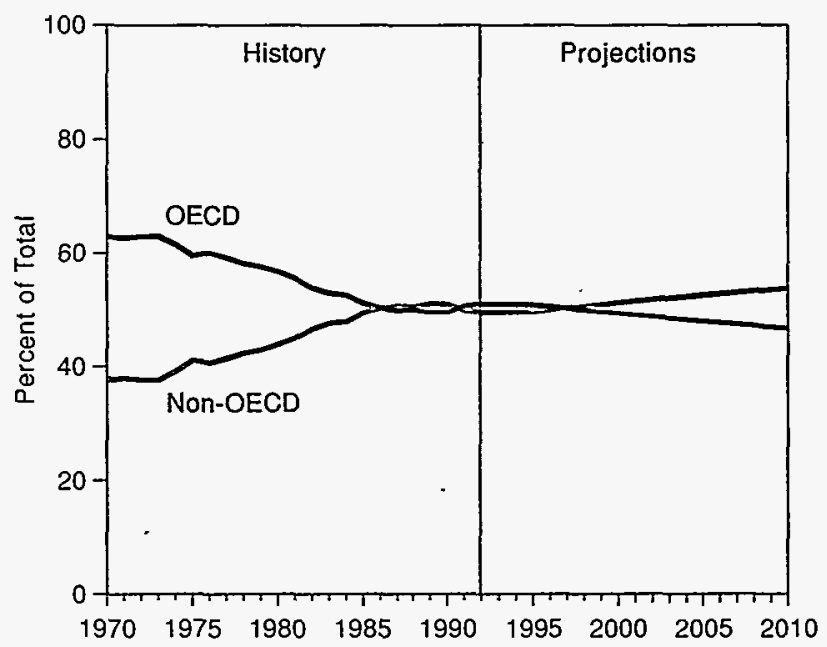

Sources: History: 1970-1979: Derived from data in Energy Information Administration (EIA), Office of Energy Markets and End Use, International Statistics Database. 1980-1992: Derived from data in EIA, International Energy Annual 1992, DOE/EIA-0219(92) (Washington, DC, January 1994). Projections: EIA, World Energy Projection System (1995). 


\title{
World Energy Consumption Trends
}

\author{
As the world's population and economic activity expand, \\ energy consumption grows. Electricity leads the growth \\ in energy demand, while oil continues to be the leading energy fuel.
}

In 1990, world energy consumption totaled more than 345 quadrillion British thermal units (Btu) (Table 1). Between 1970 and 1990 consumption increased by almost 140 quadrillion Btu, reflecting an annual growth rate of 2.6 percent. ${ }^{1}$ Oil provided the largest share of energy supply during this period, but its share of total energy declined. Among fossil fuels, natural gas consumption rose most rapidly. The share of non-fossil fuel consumption rose substantially, from 6 percent to 13 percent, between 1970 and 1990. Nuclear power consumption increased by nearly 20 quadrillion Btu, and hydroelectricity and other renewable energy sources increased by 14 quadrillion Btu.

Growth in energy consumption is expected to slow between 1990 and 2010, averaging 1.6 percent per year, compared with 2.6 percent in the previous two decades. Nonetheless, overall energy use is expected to rise by 125 quadrillion Btu. More than one-third of the incremental supply will be oil, and growth in total demand for oil between 1990 and 2010 is expected to exceed its growth in the previous two decades. Growth in nonfossil fuel use is expected to slow markedly as nuclear growth nearly ceases and growth rates for other nonfossil energy sources fall-from 3.9 percent between 1970 and 1990 to 2.3 percent between 1990 and 2010 . Because fossil fuel costs have remained competitive, their use has remained high. Although the use of renewable energy sources is growing, their market share remains low. In the case of nuclear energy, public concerns about the safety of nuclear power plants and the management of nuclear waste materials have kept the energy source from growing. Thus, while overall energy consumption growth is expected to slow in coming years, no progress is expected in reducing reliance on fossil fuels to meet rising world energy demands.

Global energy demand rises as population and economic activity expand (Figure 2). World gross domestic product (GDP), valued at about $\$ 8$ trillion (1985 U.S. dollars) in 1970, doubled to $\$ 16$ trillion in 1990 . By 2010 , world GDP is expected to increase by an additional $\$ 11$ trillion to $\$ 27$ trillion, more than triple the 1970 level. World population in 2010 is expected to exceed 7 billion, nearly 2 billion higher than in 1990 . Between 1990 and 2010 nearly twice as many people will be added to

Table 1. World Energy Consumption by Fuel, 1970-2010 (Quadrillion Btu)

\begin{tabular}{|c|c|c|c|c|c|}
\hline \multirow[b]{2}{*}{ Energy Source } & \multirow[b]{2}{*}{1970} & \multirow[b]{2}{*}{1990} & \multirow[b]{2}{*}{2010} & \multicolumn{2}{|c|}{ Annual Percent Change } \\
\hline & & & & $1970-1990$ & $1990-2010$ \\
\hline Oil & 97.8 & 135.4 & 181.3 & 1.6 & 1.5 \\
\hline Natural Gas & 36.1 & 72.0 & 106.8 & 3.5 & 2.0 \\
\hline Coal . .......... & 59.7 & 91.9 & 118.0 & 2.2 & 1.3 \\
\hline Nuclear $\ldots \ldots \ldots \ldots$ & 0.9 & 20.3 & 24.4 & 16.9 & 0.9 \\
\hline Renewables. & 12.2 & 26.2 & 41.1 & 3.9 & 2.3 \\
\hline Total $\ldots \ldots \ldots \ldots$ & 206.7 & 345.6 & 471.7 & 2.6 & 1.6 \\
\hline
\end{tabular}

Note: Totals may not equal sum of components due to independent rounding.

Sources: History: Energy Information Administration (EIA), Office of Energy Markets and End Use, International Statistics Database; and International Energy Annual 1992, DOE/EIA-0219(92). Projections: EIA, World Energy Projection System (1995).

\footnotetext{
${ }^{1}$ The data presented in the IEO95 text and tables are rounded numbers derived from detailed model projections and estimates. The percentages shown in the report were calculated from the unrounded values. Therefore, percentages in the text may not agree precisely with percentages calculated from the rounded numbers.
} 
Figure 2. World Trends, 1970-2010

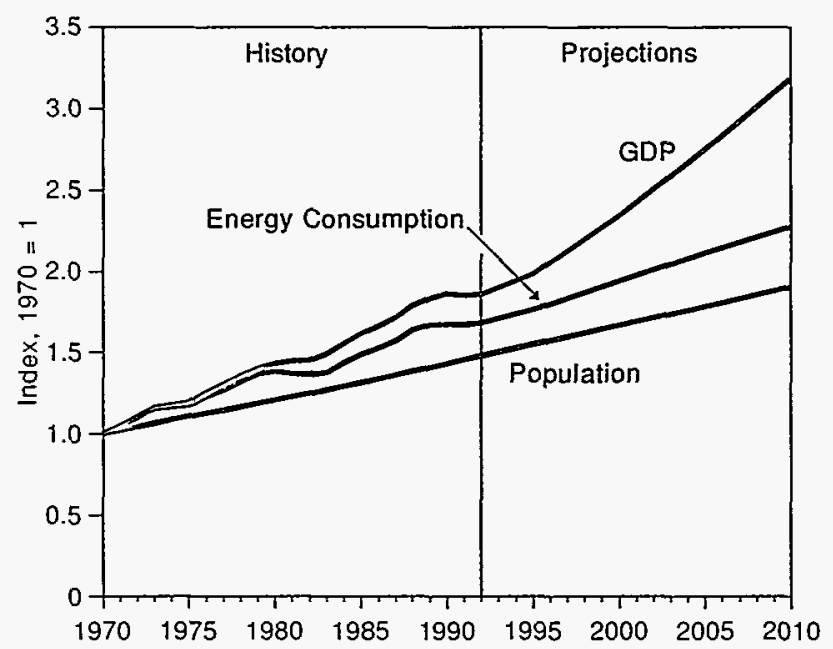

Sources: History: 1970-1979: Energy Information Administration (EIA), Office of Energy Markets and End Use, International Statistics Database. 1980-1992: EIA, International Energy Annual 1992, DOE/ EIA-0219(92) (Washington, DC, January 1994). Projections: EIA, World Energy Projection System (1995). Gross Domestic Product (GDP): The WEFA Group, World Economic Service Historical Data (Bala Cynwyd, PA, July 1993); and World Economic Outlook, Vols. 1 and 3 (Bala Cynwyd, PA, October 1994). Population: United Nations, World Population Prospects: The 1994 Revision Annex Tables (New York, NY, 1994), Tables A.1 and A.2.

the world population as were added between 1970 and 1990, so that the population in 2010 will be nearly double the 1970 population.

The largest shares of world economic growth and population growth are expected in areas where current energy use is small relative to that in the mature industrialized countries of the Organization for Economic Cooperation and Development (OECD). Thus, energy consumption grows at a rate intermediate between those for population and economic growth, more than doubling between 1970 and 2010. If energy consumption levels in the non-OECD countries were to match those in the OECD on a per capita basis, world energy demand would increase more than five times relative to current and projected levels (Figure 3). For example, at OECD per capita consumption rates, the non-OECD countries would have consumed 844 quadrillion Btu of energy in 1990, as opposed to their actual 1990 consumption of 162 quadrillion Btu. Similarly, if the non-OECD countries consumed as much energy per person as the OECD countries are projected to consume in 2010, their level of energy use would be 1,325 quadrillion Btu, almost six times as high as the Reference Case projection of 233 quadrillion Btu.

The International Energy Outlook 1995 (IEO95) does not project such a dramatic rise in energy consumption, because substantial gains in income in both developed and developing areas of the world are expected to be achieved without comparable gains in energy requirements. Energy intensity of economic activity is projected to decline steadily worldwide. Between 1970 and 1990, substantial declines in energy intensity were achieved in industrialized (OECD) countries. Further declines are expected in these areas, reflecting expanded use of energy-efficient technologies. Similar declines are expected in non-OECD countries, particularly in Eastern Europe and the former Soviet Union (EE/FSU), as market-oriented policies and economic recovery take hold and energy-efficient technologies are adopted. Efficient technologies are also expected to be adopted in major developing countries, most notably including China and India, where economic growth is rapid. Worldwide, energy intensity is projected to decline from 22 to 17 thousand Btu per dollar of GDP between 1990 and 2010.

Figure 3. World Energy Consumption, 1990 and 2010, Assuming OECD Energy Consumption Rates per Capita

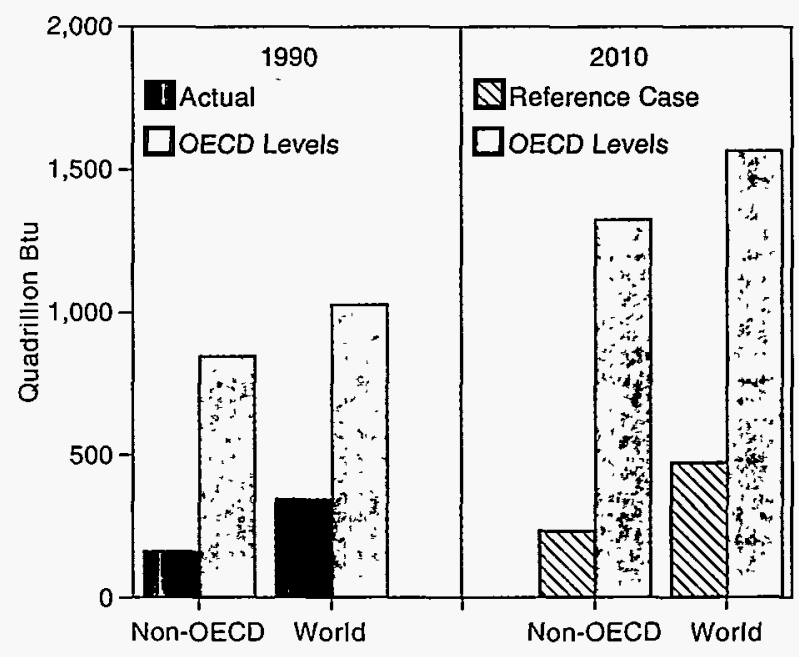

Sources: History: Energy Information Administration (EIA), International Energy Annual 1992, DOE/EIA-0219(92) (Washington, DC, January 1994). Projections: EIA, World Energy Projection System (1995). 


\section{Demand Uncertainty}

Substantial uncertainty attends any long-term projection of energy demand. Sources of uncertainty include economic growth rates, energy prices, and the intensity of energy use in developing economic systems. To prepare a forecast, baseline assumptions for these important variables must be established. The assumptions for economic growth rates underlying the IEO95 projections are presented in Table 2. Over time, substantial variations in growth rates occur within and between regions. For example, in the mid-1980s, few anticipated the economic collapse of the EE/FSU. This report assumes substantial recovery for those areas over the next decade. The explosive growth rate for non-OECD Asia-especially China and India-is expected to lessen somewhat. Within the OECD, the United States is expected to experience the slowest rate of economic growth, largely because of higher interest rates $[1, p .1]$.

Just as growth rates are uncertain, so too are energy prices. This report assumes relatively stable energy prices over the forecast horizon. Historically, oil prices have contributed substantially to energy price volatility (Figure 4). The IEO95 Reference Case oil projection depicts a slow rise in oil prices through 2010, with levels at the end of the forecast horizon well below those for most years prior to the 1970-1990 period (Figure 4).

Changes in energy intensity could also have a significant impact on the projections presented in this report. In industrialized countries, declining trends in energy intensity have persisted over two decades. The patterns in the developing countries are more diverse. In some areas energy use has risen relative to income; often, such developments reflect the emergence of energyintensive industries. Other factors associated with economic development that have significant impacts on energy use include the spread of electricity use as a substitute for noncommercial fuels (plant materials and animal wastes) used for household energy, and the increasing use of motor vehicles for private and commercial transportation. Were energy intensities in developing areas to remain constant at recent levelsinstead of declining as projected in this report-world energy requirements in 2010 could be as much as 92

Table 2. Annual Growth Rates in Gross Domestic Product by Region and for Selected Countries, 1970-2010 (Percent per Year)

\begin{tabular}{|c|c|c|c|c|c|c|}
\hline \multirow[b]{2}{*}{ Region/Country } & \multicolumn{2}{|c|}{ History } & \multicolumn{4}{|c|}{ Projections } \\
\hline & $1970-1980$ & $1980-1990$ & $1990-2000$ & $2000-2010$ & $1970-2010$ & $1990-2010$ \\
\hline OECD $\ldots \ldots \ldots \ldots \ldots \ldots \ldots$ & 3.3 & 2.8 & 2.3 & 2.4 & 2.7 & 2.3 \\
\hline North America & 3.0 & 2.6 & 2.3 & 2.1 & 2.5 & 2.2 \\
\hline United States & 2.8 & 2.6 & 2.3 & 2.0 & 2.4 & 2.1 \\
\hline Canada $\ldots \ldots \ldots \ldots \ldots \ldots$ & 4.6 & 2.9 & 2.2 & 2.3 & 3.0 & 2.3 \\
\hline Mexico $\ldots \ldots \ldots \ldots \ldots$ & 6.7 & 1.7 & 3.3 & 3.7 & 3.8 & 3.5 \\
\hline Europe $\ldots \ldots \ldots \ldots \ldots \ldots$ & 3.2 & 2.4 & 2.0 & 2.5 & 2.5 & 2.3 \\
\hline Pacific $\ldots \ldots \ldots \ldots \ldots \ldots$ & 4.3 & 4.0 & 2.7 & 2.8 & 3.5 & 2.8 \\
\hline Japan $\ldots \ldots \ldots \ldots \ldots \ldots$ & 4.5 & 4.1 & 2.7 & 2.8 & 3.5 & 2.8 \\
\hline EE/FSU $\ldots \ldots \ldots \ldots \ldots \ldots$ & 3.3 & 1.6 & -2.7 & 4.1 & 1.5 & 0.6 \\
\hline Former Soviet Union . . . . . . . & 3.2 & 2.0 & -3.8 & 4.2 & 1.4 & 0.1 \\
\hline Eastern Europe $\ldots \ldots \ldots \ldots$ & 3.5 & 0.3 & 0.8 & 3.6 & 2.1 & 2.2 \\
\hline Non-OECD Asia . . . . . . . . . & 6.0 & 7.2 & 6.8 & 5.5 & 6.4 & 6.1 \\
\hline China...$\ldots \ldots \ldots \ldots \ldots$ & 5.8 & 8.9 & 8.9 & 6.0 & 7.4 & 7.4 \\
\hline Other Asia ....... & 6.0 & 6.5 & 5.7 & 5.2 & 5.8 & 5.4 \\
\hline Middle East $\ldots \ldots \ldots \ldots \ldots$ & 5.2 & 0.9 & 4.0 & 3.7 & 3.5 & 3.9 \\
\hline$\ldots \ldots \ldots \ldots \ldots \ldots$ & 4.2 & 1.4 & 2.6 & 2.9 & 2.8 & 2.8 \\
\hline Central and South America ..... & 5.6 & 1.1 & 3.7 & 3.6 & 3.5 & 3.7 \\
\hline Total World $\ldots \ldots \ldots \ldots \ldots \ldots$ & 3.6 & 2.7 & 2.3 & 3.1 & 2.9 & 2.7 \\
\hline
\end{tabular}

Sources: History: Derived from The WEFA Group, World Economic Service Historical Data (July 1993). Projections: The WEFA Group, World Economic Outlook, Vols. 1 and 3 (Bala Cynwyd, PA, October 1994); U.S. data from Energy Information Administration (EIA), Annual Energy Outlook 1995, DOE/EIA-0383(95) (Washington, DC, January 1995); and EIA, World Energy Projection System (1995). 
Figure 4. World Oil Price Ranges, 1970-2010

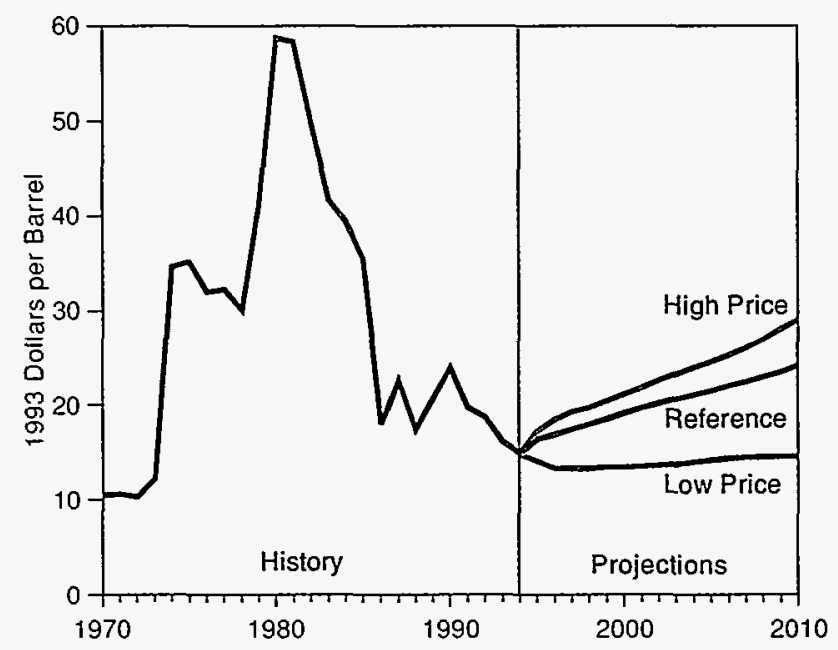

Sources: History: Energy Information Administration (EIA), Annual Energy Review 1993, DOE/EIA-0384(93) (Washington, DC, July 1994). Projections: EIA, Annual Energy Outlook 1995, National Energy Modeling System runs LWOP95.D1103941, AEO95B.D1103942, and HWOP95.D1103942.

quadrillion Btu higher than the Reference Case projection (Table 3).

If substantial improvements in energy intensity are not achieved over the forecast horizon, consumption could be larger than in the Reference Case projections. To the extent that intensity improvements are not achieved, substantially more rapid development of energy supplies - or higher energy prices-will be necessary. Lower demand for energy is also possible, particularly if economic recovery in the EE/FSU is delayed substantially and other economies grow more slowly than assumed.

\section{OECD and Non-OECD Energy Trends}

Since 1970, energy consumption has increased more rapidly in the non-OECD countries than in those of the OECD. That trend is expected to continue throughout the projection period. In fact, while consumption in the non-OECD countries constituted only one-third of the world's total energy consumption in 1970, by 2010 it reaches nearly one-half of total energy consumption in the Reference Case (Figure 5). Between 1970 and 1990,

Figure 5. OECD and Non-OECD Energy Consumption, 1970-2010

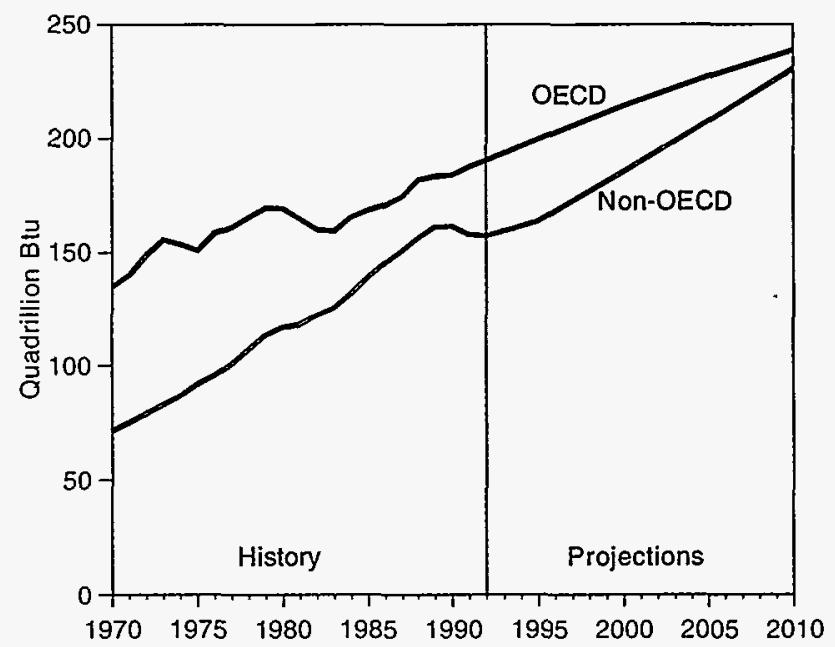

Sources: History: 1970-1979: Energy Information Administration (EIA), Office of Energy Markets and End Use, International Statistics Database. 1980-1992: EIA, International Energy Annual 1992, DOE/ EIA-0219(92) (Washington, DC, January 1994). Projections: EIA, World Energy Projection System (1995).

Table 3. Variation in Energy Consumption in 2010, Given Alternative Assumptions About Energy Intensity (Quadrillion Btu)

\begin{tabular}{|c|c|c|}
\hline \multirow[b]{2}{*}{ Alternative Assumptions } & \multicolumn{2}{|c|}{ Energy Consumption, 2010} \\
\hline & Non-OECD & World Total \\
\hline $\begin{array}{l}\text { IEO95 Reference Case (non-OECD energy intensity } \\
\text { reaches } 22.8 \text { thousand Btu per } 1985 \text { dollar in 2010) }\end{array}$ & 233 & 472 \\
\hline $\begin{array}{l}\text { Non-OECD energy intensity remains at its } 1992 \text { level } \\
\text { ( } 31.8 \text { thousand Btu per } 1985 \text { dollar) through } 2010 \ldots\end{array}$ & 324 & 563 \\
\hline $\begin{array}{l}\text { Non-OECD energy intensity grows at its } 1970-1992 \text { rate through } \\
2010 \text {, reaching } 35.9 \text { thousand Btu per } 1985 \text { dollar in } 2010 \ldots \text {. }\end{array}$ & 366 & 605 \\
\hline $\begin{array}{l}\text { Non-OECD energy intensity falls to the level projected for the OECD } \\
\text { (14.1 thousand Btu per } 1985 \text { dollar) in } 2010 \ldots \ldots \ldots \ldots \ldots \ldots\end{array}$ & 144 & 383 \\
\hline
\end{tabular}

Source: Energy Information Administration, World Energy Projection System (1995). 


\section{Sensitivity Ranges for IEO95 Projections}

Any long-term energy projection is an approximation with a significant band of uncertainty. In IEO95, uncertainty is conveyed by a set of "sensitivity ranges" surrounding the Reference Case projections. For total world energy consumption, the sensitivity range is about 50 quadrillion Btu above and below the Reference Case value for 2010 (Figure 6).

A deterministic method-not a probability approachwas used to compute sensitivity ranges. Using the total consumption projections as an example, the following method was used to compute the high end of the sensitivity range for each year by region and, in some cases, for selected countries.

First, assuming higher rates of economic growth (1.0 percentage point above the Reference Case growth rate), the resulting difference in consumption relative to the Reference Case level was calculated for each year, and the differences were squared. Second, assuming higher energy intensity ( 30 percent higher than the Reference Case ratio of energy consumed per dollar of GDP), the differences from the Reference Case values were again calculated and squared. Third, the squares of the differences from the first two steps were added, and the square roots of the sums were calculated. Finally, the results from the third step were added to the respective Reference Case values.

The result of these calculations is a high range value for total energy consumption that differs from the Reference Case projection by more than either of the two differences derived by changing a single assumption, but by less than the difference that would have resulted if the two changed assumptions had been considered simultaneously. The low range for total energy consumption was determined in the same way, assuming economic growth rates 1 percentage point below the Reference Case rate and energy intensity 30 percent lower than the Reference Case ratio. energy consumption in the OECD grew steadily, averaging 1.6 percent per year (Table 4). After 1990, the growth rate declines to 1.3 percent annually, reflecting the implementation of more efficient technologies.

\section{Figure 6. Total World Energy Consumption, 1970-2010}

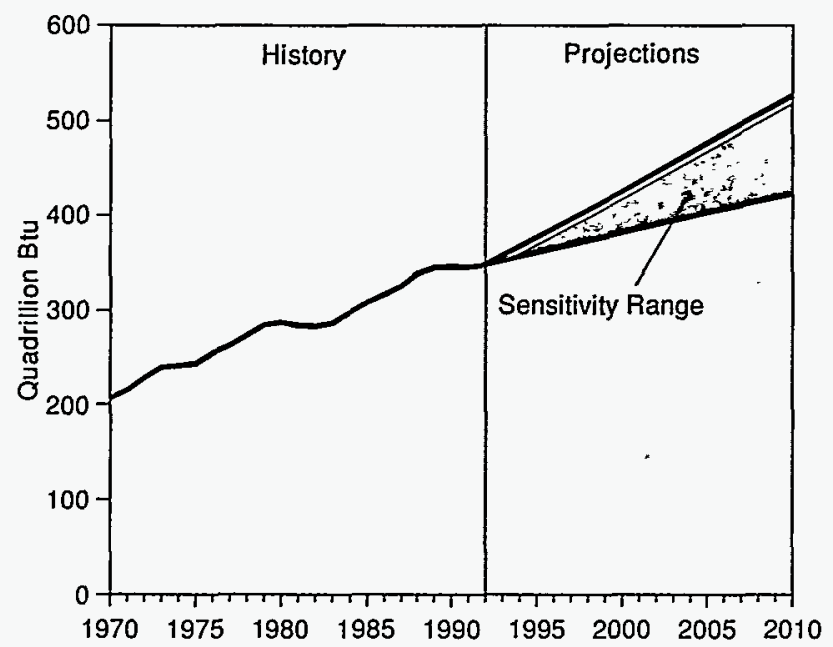

Sources: History: 1970-1979: Energy Information Administration (EIA), Office of Energy Markets and End Use, International Statistics Database. 1980-1992: EIA, International Energy Annual 1992, DOE/EIA-0219(92) (Washington, DC, January 1994). Projections: EIA, World Energy Projection System (1995).
In contrast, non-OECD energy consumption more than doubled between 1970 and 1990, with growth averaging 4.2 percent per year (Table 4). Over the 1990 to 2010 period, non-OECD growth rates are expected to continue to exceed those of the OECD, but the pace of energy demand growth is expected to slow to less than 2 percent per year. The slower growth reflects, in part, the economic collapse and slow recovery of the EE/FSU countries. It also reflects slower growth and improved energy intensities in rapidly developing areas of the world, including, most notably, China, India, and other countries of Asia. Even with slowing growth, nonOECD areas are expected to account for nearly 60 percent of the projected change in energy demand between 1990 and 2010 (Table 4).

The OECD and non-OECD countries differ distinctly in the mix of energy resources they use (Figures 7 and 8). Coal is a much more important energy source in the non-OECD countries than for the OECD, as it has been since the 1970s (Table 4 and Figure 8). In relative terms, reliance on coal is expected to increase the most, with 75 percent of the growth in world demand for coal in 2010 accounted for by non-OECD countries. Coal and oil compete closely in the non-OECD countries until after 1995, when oil overtakes coal as the leading source of energy supply. Natural gas use also rises substantially in the non-OECD countries, from a 13-percent share of total energy consumption in 1970 to 23 percent in 2010 (Figure 8). 
Table 4. World Energy Consumption by Region and Fuel, 1970-2010 (Quadrillion Btu)

\begin{tabular}{|c|c|c|c|c|c|}
\hline \multirow[b]{2}{*}{ Region/Energy Source } & \multirow[b]{2}{*}{1970} & \multirow[b]{2}{*}{1990} & \multirow[b]{2}{*}{2010} & \multicolumn{2}{|c|}{ Annual Percent Change } \\
\hline & & & & $1970-1990$ & $1990-2010$ \\
\hline OECD & 135.1 & 183.8 & 239.0 & 1.6 & 1.3 \\
\hline Oil ....... & 70.6 & 79.7 & 98.2 & 0.6 & 1.0 \\
\hline Natural Gas ........ & 27.1 & 34.9 & 53.9 & 1.3 & 2.2 \\
\hline Coal $\ldots \ldots \ldots \ldots$ & 27.7 & 37.5 & 44.0 & 1.5 & 0.8 \\
\hline Nuclear $\ldots \ldots \ldots \ldots$ & 0.8 & 16.2 & 18.7 & 16.0 & 0.7 \\
\hline Renewables & 8.8 & 15.7 & 24.0 & 2.9 & 2.1 \\
\hline Non-OECD . . . . . . . . & 71.7 & 161.8 & 232.7 & 4.2 & 1.8 \\
\hline Oil ...... & 27.2 & 55.7 & 83.1 & 3.7 & 2.0 \\
\hline Natural Gas & 9.1 & 37.1 & 52.9 & 7.3 & 1.8 \\
\hline Coal ...... & 32.0 & 54.4 & 74.0 & 2.7 & 1.6 \\
\hline Nuclear ... & 0.1 & 4.1 & 5.6 & 23.1 & 1.6 \\
\hline Renewables . . . . . . . & 3.3 & 10.5 & 17.1 & 5.9 & 2.5 \\
\hline
\end{tabular}

Sources: History: Energy Information Administration (EIA), Office of Energy Markets and End Use, International Statistics Database; and International Energy Annual 1992, DOE/EIA-0219(92). Projections: EIA, World Energy Projection System (1995).

In contrast, the OECD countries use twice as much oil as any other single energy source from 1970 through the end of the projection period (Table 4 and Figure 7). Breaks in the oil consumption time series occurred in the mid-1970s and early 1980s because of the OPEC oil embargo in 1973 and the oil price shock in 1979 (Figure 4). Since the mid-1980s, however, oil consumption has

Figure 7. OECD Energy Consumption by Fuel Type, 1970-2010

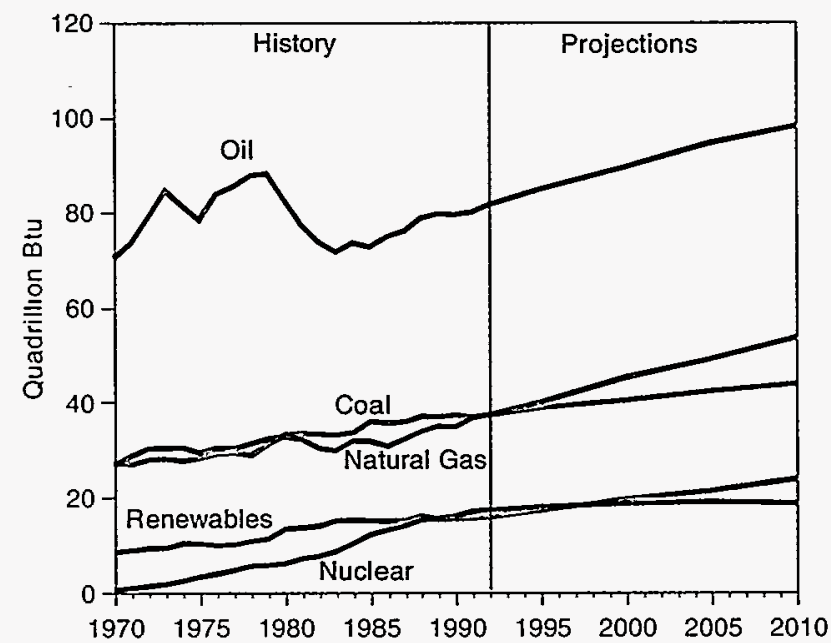

Sources: History: 1970-1979: Energy Information Administration (EIA), Office of Energy Markets and End Use, International Statistics Database. 1980-1992: ElA, International Energy Annual 1992, DOE/ EIA-0219(92) (Washington, DC, January 1994). Projections: EIA, World Energy Projection System (1995). increased steadily. Continued increases in OECD oil use are expected throughout the projection period, although oil loses some of its market share, falling from 43 percent of total OECD energy consumption in 1990 to 41 percent in 2010. By comparison, oil claimed a record 55 percent of the OECD energy market in 1973.

Figure 8. Non-OECD Energy Consumption by Fuel Type, 1970-2010

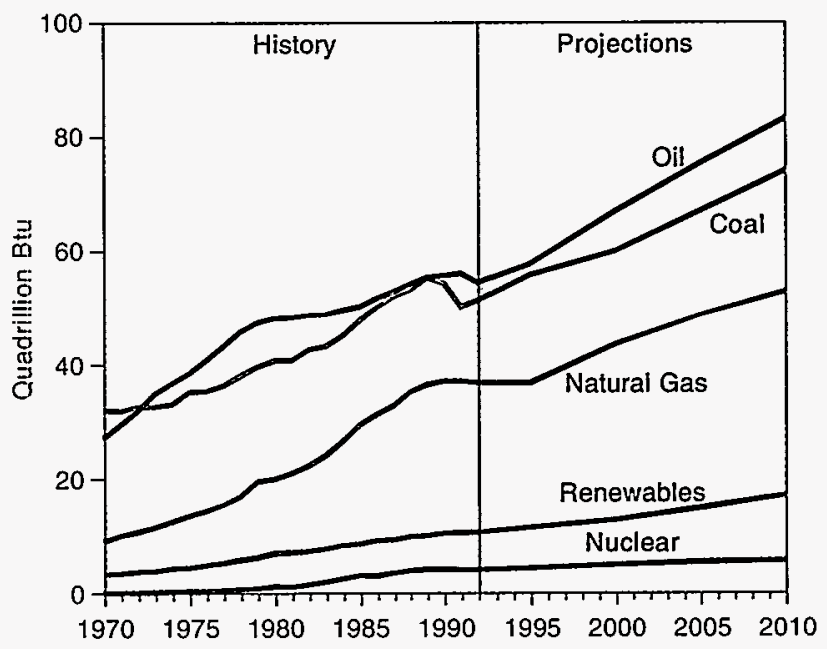

Sources: History: 1970-1979: Energy Information Administration (EIA), Office of Energy Markets and End Use, International Statistics Database. 1980-1992: EIA, International Energy Annual 1992, DOE/ EIA-0219(92) (Washington, DC, January 1994). Projections: EIA, World Energy Projection System (1995). 
Natural gas and coal have competed for second place in the OECD countries since 1970. After 1995, natural gas takes a clear lead (Figure 7), as coal's share of consumption drops from 21 percent in 1970 to 18 percent in 2010. The reduced coal share in OECD countries reflects the efforts of industrialized nations to reduce pollution and carbon emissions by switching to cleaner fuels. Natural gas, a cleaner fuel than coal, has a slightly expanding market share over the 1970 to 2010 time span, growing from 19 percent of total energy consumption in 1970 to 22 percent in 2010.

Nuclear energy gained market share through the 1970s and 1980s. The OECD nuclear share grew from less than 1 percent of total consumption in 1970 to a current peak of 9 percent (Figure 7). In contrast, nuclear energy is expected to lose market share slightly in OECD countries by the end of the projection period, falling to just below 8 percent in 2010. Public concerns about the safety of nuclear energy and about managing nuclear waste materials account for the decline. Nuclear power remains a very small share of total energy consumption in the non-OECD countries throughout the projection period (Figure 8), mainly because of the large amounts of capital required for construction of nuclear plants. In the non-OECD countries, even at the end of the projection period, nuclear power never attains even half the market share of renewable fuels. In OECD countries, nuclear energy consumption overtook renewables in the late 1980s, but it is expected to lose market share to renewables by the end of the projection period (Figure 7).

Consumption of renewable energy sources in the OECD almost doubled between 1970 and 1990, growing from 9 to 16 quadrillion Btu (Figure 7). Renewable energy consumption remains strong in the OECD throughout the projection period, reaching 24 quadrillion Btu in 2010 , with annual growth of 2.1 percent per year between 1990 and 2010. Increased support for renewable technology research is primarily responsible for the gains of these resources in the OECD.

Over the past two decades, consumption of renewable energy sources in non-OECD countries has nearly quadrupled, from only 3 quadrillion Btu in 1970 to 11 quadrillion Btu in 1990. Growing demand for electric power-particularly among the non-OECD countriesis expected to help renewable energy grow faster than any other energy source between 1990 and 2010. Consumption of energy from renewable sources in the nonOECD countries is projected to grow by 3.3 percent annually between 1990 and 2010, reaching 17 quadrillion Btu by the end of the forecast period.

Energy consumption in the OECD has, since the mid1970s, grown more slowly than GDP (Figure 9). The divergence developed subsequent to the oil price crisis of 1973 (a result of the OPEC oil embargo) but has persisted even as oil and other energy prices have fallen to pre-crisis levels in real terms. Whereas by $2010 \mathrm{GDP}$ is almost three times its 1970 level, energy consumption is less than twice its 1970 level. In contrast, energy demand has risen at a more rapid rate than GDP in non-OECD areas (Figure 10). This pattern is expected to persist during the early years of the projection period. Between 2000 and 2010, however, a relationship between energy and economic growth similar to that achieved in OECD countries is expected to emerge.

\section{Figure 9. OECD Trends, 1970-2010}

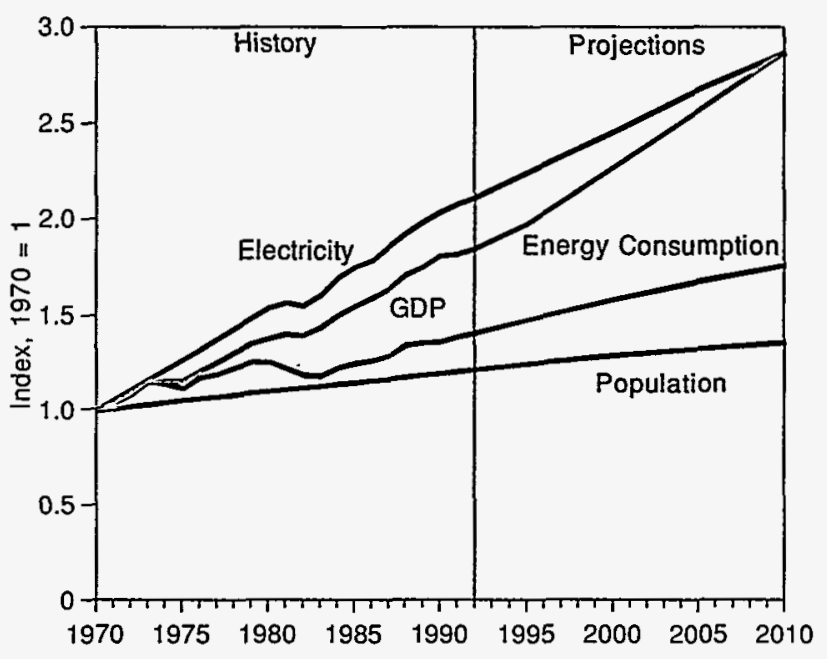

Sources: History: 1970-1979: Energy Information Administration (ElA), Office of Energy Markets and End Use, International Statistics Database. 1980-1992: ElA, International Energy Annual 1992, DOE ElA-0219(92) (Washington, DC, January 1994). Projections: EIA, World Energy Projection System (1995). Gross Domestic Product (GDP): The WEFA Group, World Economic Service Historical Data (Bala Cynwyd, PA, July 1993); and World Economic Outlook, Vol. 1 (Bala Cynwyd, PA, October 1994). Population: United Nations, World Population Prospects: The 1994 Revision Annex Tables (New York, NY, 1994), Tables A.1 and A.2.

The future path of energy intensity for the non-OECD nations is subject to much more uncertainty and is therefore more difficult to project than that for OECD nations. Figure 11 depicts historic and projected energy intensities used in this report. Particularly for the economies that are expanding rapidly, the expansion rates of key sectors, such as electricity generation (associated with expanding electricity consumption), transportation, and energy-intensive manufacturing industries, will be key determinants of trends in energy intensity. Equally important is the type of capital equipment used in these sectors, as energy intensity will vary considerably depending upon the energy-use characteristics of new equipment. 
The dynamics of growth in energy consumption are demonstrated by considering an approximate measure of the elasticity of change in energy consumption relative to change in GDP. To smooth the year-to-year differences, the elasticity is calculated for a 5-year period by dividing the percentage change in energy consumption by the percentage change in GDP. When the elasticity is greater than 1 , each percentage point increase in GDP results in more than 1 percentage point increase in consumption. Consequently, when the average elasticity is greater than 1, energy intensity is increasing; and when it is less than 1, energy intensity is decreasing.

For OECD nations, the energy-to-GDP elasticity has typically been less than 1 , although it comes close to 1 for the 1990 to 1995 period (Table 5). The economic troubles of the EE/FSU countries have distorted the picture for non-OECD nations in the 1990 to 1995 period. Consequently, average elasticities were also computed for the non-OECD nations excluding EE/FSU. ${ }^{2}$ For these nations, the average elasticity hovers around 1 for the 1970 to 1980 period, corresponding to relatively flat energy intensity values

\section{Figure 10. Non-OECD Trends, 1970-2010}

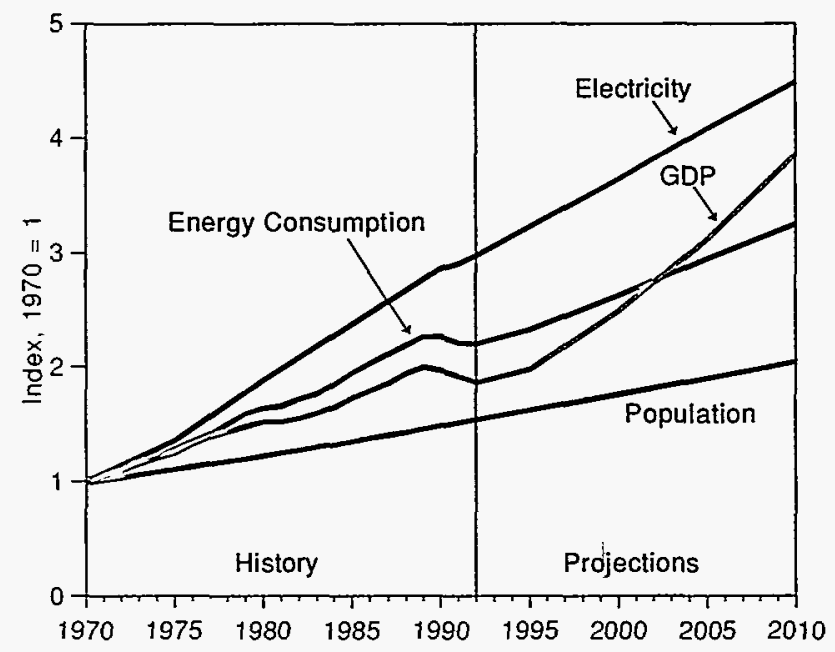

Sources: History: 1970-1979: Energy Information Administration (EIA), Office of Energy Markets and End Use, International Statistics Database. 1980-1992: EIA, International Energy Annual 1992, DOEI EIA-0219(92) (Washington, DC, January 1994). Projections: EIA, World Energy Projection System (1995). Gross Domestic Product (GDP): The WEFA Group, World Economic Senvice Historical Data (Bala Cynwyd, PA, July 1993); and World Economic Outlook, Vol. 3 (Bala Cynwyd, PA, October 1994). Population: United Nations, World Population Prospects: The 1994 Revision Annex Tables (New York, NY, 1994), Tables A.1 and A.2.
Figure 11. World Energy Intensities, OECD and Non-OECD, 1970-2010

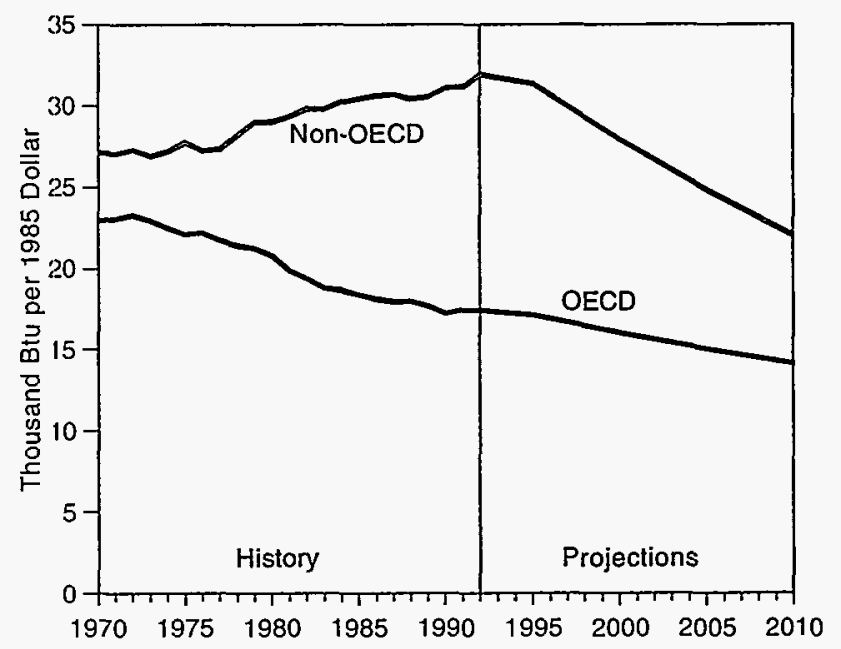

Sources: History: 1970-1979: Energy Information Administration (EIA). Office of Energy Markets and End Use, International Statistics Database. 1980-1992: EIA, International Energy Annual 1992, DOE/ EIA-0219(92) (Washington, DC, January 1994). Projections: EIA, World Energy Projection System (1995).

(Figure 11). For 1980 to 1985, the average elasticity increased to almost 2 , and it has subsequently declined through 1995 (with the 1990 to 1995 figure including some projected values as well as historical values).

The decline in energy intensity for non-OECD nations is projected to continue through 2010 in the IEO95 forecasts. The projected rate of change for energy intensity approaches that for OECD nations, which would be the case if the expansion of GDP in developing nations at the end of the forecast period were associated with the same increase in energy consumption as is an increase in GDP for OECD nations. This assumption presumes, among other factors, that nonOECD nations by 2010 will be adopting technologies with the same energy-use characteristics as those used in OECD nations. This could come about through pressures for economic efficiency as the economies in non-OECD nations become more market driven and more integrated into a world market. Environmental considerations could be another factor contributing to the adoption of similar technologies around the world. One indication that this assumption is feasible is the situation in China, one of the most rapidly developing countries in the world in recent years: the average growth rate for energy intensity in China has not exceeded 1 over the past two decades and has tended to stay closer to 0.5 .

\footnotetext{
${ }^{2}$ In the 1990 to 1995 period, for all non-OECD nations, the average growth in energy intensity is 6.3. The large value results from the combination of declines in GDP and energy consumption in EE/FSU with positive values for most of the rest of the non-OECD countries. The average energy intensity of 0.56 for the EE/FSU indicates that energy consumption did not fall as rapidly as did GDP. The decline in EE/FSU energy consumption and GDP is large enough to distort the non-OECD picture.
} 
Table 5. Average Energy Elasticity (Change in Consumption Versus Change in Gross Domestic Product), 1970-2010: World, OECD, Non-OECD, and Non-OECD Asia

\begin{tabular}{|c|c|c|c|c|c|c|c|c|}
\hline \multirow[b]{2}{*}{ Region/Country } & \multicolumn{4}{|c|}{ History } & \multicolumn{4}{|c|}{ Projections } \\
\hline & 1975 & 1980 & 1985 & 1990 & 1995 & 2000 & 2005 & 2010 \\
\hline Total World & 0.92 & 0.89 & 0.59 & 0.78 & 0.94 & 0.55 & 0.52 & 0.47 \\
\hline OECD & 0.74 & 0.63 & -0.03 & 0.54 & 0.96 & 0.49 & 0.46 & 0.43 \\
\hline Non-OECD . . & 1.10 & 1.26 & 1.41 & 1.17 & 6.33 & 0.51 & 0.48 & 0.43 \\
\hline Non-OECD without EE/FSU & 1.01 & 1.02 & 1.99 & 1.19 & 0.78 & 0.57 & 0.54 & 0.47 \\
\hline Non-OECD Asia $\ldots \ldots \ldots \ldots$ & 1.03 & 0.66 & 0.76 & 0.73 & 0.64 & 0.52 & 0.51 & 0.44 \\
\hline China & 0.86 & 0.53 & 0.44 & 0.58 & 0.40 & 0.46 & 0.46 & 0.44 \\
\hline Other Asia & 1.25 & 0.90 & 1.08 & 0.91 & 0.90 & 0.57 & 0.54 & 0.41 \\
\hline
\end{tabular}

Notes: $\mathrm{OECD}=$ Organization for Economic Cooperation and Development. EE/FSU $=$ Eastern Europe/Former Soviet Union. The elasticity was calculated for each 5 -year period by dividing the percentage change in energy consumption by the percentage change in GDP.

Sources: History: Derived using gross domestic product data from The WEFA Group, World Economic Service Historical Data (July 1993), and energy consumption data from Energy Information Administration (EIA), International Energy Annual 1992, DOE/EIA-0219(92) (Washington, DC, January 1994). Projections: ElA, World Energy Projection System (1995).

Because assumptions about energy intensity have such a strong influence on energy consumption projections, it is useful to consider the effects of alternative assumptions. If energy intensity in the non-OECD nations remained at 31.8, its value in 1992, their total energy consumption in 2010 would be 324 quadrillion Btu (Table 3), an increase of 92 quadrillion Btu over the Reference Case projection. If energy intensity continued to grow to 2010 in non-OECD countries at the same average rate by which it grew over the 1970 to 1992 period, total energy consumption would be 366 quadrillion Btu, an increase of 133 quadrillion Btu from the Reference Case. The latter estimate is an extreme upper bound on possible energy consumption for the nonOECD countries, because in the past two decades, no country of the world-let alone an entire region-has sustained an equivalent level of growth in energy intensity. It does, however, provide an estimate for bracketing the projections of energy consumption growth. Likewise, if energy intensity in non-OECD countries declined to the same level as that projected for the OECD countries, total non-OECD energy consumption in 2010 would be 144 quadrillion Btu, 89 quadrillion Btu less than the Reference Case forecast.

Throughout the world, the most rapidly growing component of energy demand is electricity (Figures 9 and 10). In the OECD, electricity showed strong growth between 1970 and 1990 at 3.7 percent per year, in contrast to 1.6 percent per year for total energy. Between 1990 and 2010 the growth rate of electricity in the OECD is projected to slow to 1.7 percent per year.
Electricity consumption in non-OECD countries grew by 5 percent per year between 1970 and 1990 and is expected to grow by 2.3 percent per year between 1990 and 2010 (Table A8). Electricity growth has been particularly strong in non-OECD Asia, where the 1990 level of electricity consumption was almost five times its 1970 level (Figure 12). In that region, electricity consumption is expected to more than double again by

\section{Figure 12. Non-OECD Electricity Consumption} by Region, $1970-2010$

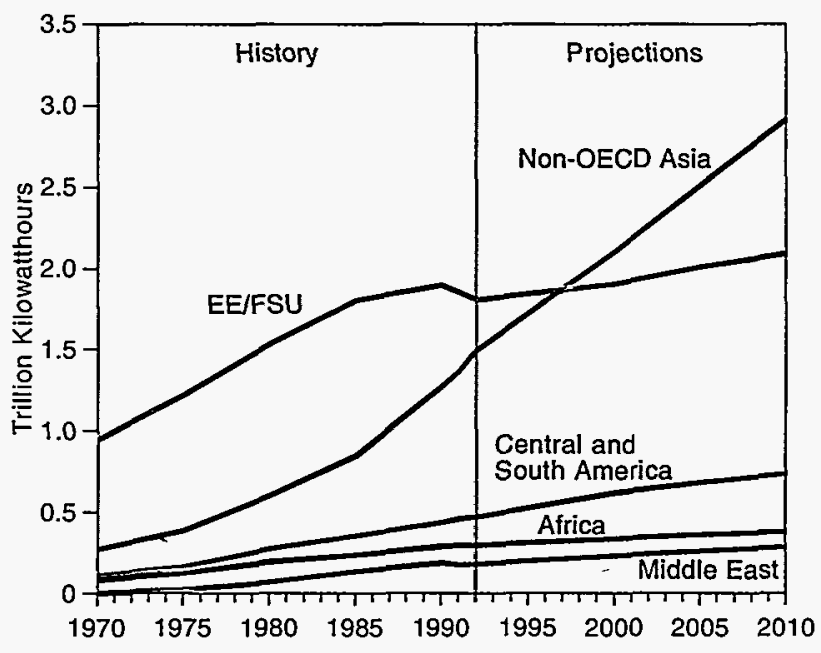

Sources: History: 1970-1979: Energy Information Administration (EIA), Office of Energy Markets and End Use, International Statistics Database. 1980-1992: EIA, International Energy Annual 1992, DOE/ EIA-0219(92) (Washington, DC, January 1994). Projections: EIA, World Energy Projection System (1995). 
the end of the projection period, as aggressive industrialization and urbanization plans correspond to aggressive development of electricity supplies (Figure 12).

Population is expected to increase by more than 2 billion people between 1990 and 2010, after increasing by more than 1 billion between 1970 and 1990 (Figure 13). Increases in the world population throughout the 1970 to 2010 time span are almost exclusively attributable to increases in the non-OECD population. OECD population remains almost flat throughout the time series, with only slight increases between 1970 and the mid1980 s and again toward the end of the projection period. In contrast, the non-OECD population doubles between 1970 and the end of the projection period, growing steadily throughout the 40 -year time periodby 1.8 percent per year between 1970 and 1990 and by 1.7 percent per year between 1990 and 2010 .

Figure 13. World Population by Region, 1970-2010

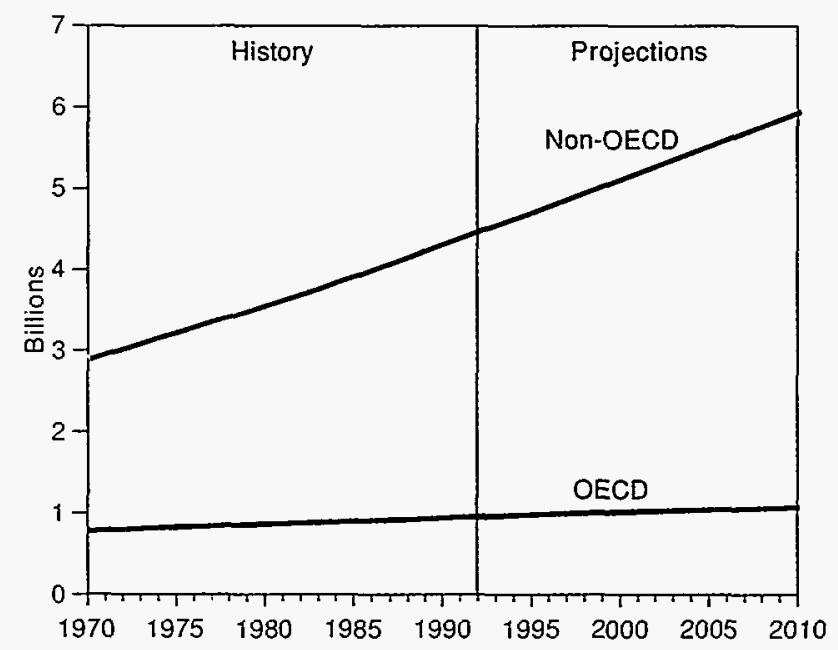

Source: United Nations, World Population Prospects: The 1994 Revision Annex Tables (New York, NY, 1994), Tables A.1 and A.2.

The industrialized OECD countries remain substantially larger energy consumers per capita than the non-OECD countries (Figure 14). Consumption per capita in the OECD is more than five times the non-OECD level throughout the 40-year span, and almost six times higher at the end of the projection period as the population growth rate in the non-OECD countries exceeds the growth rate of energy consumption. In the non-OECD countries, energy consumption per capita grows slightly between 1990 and 2010, from 37.3 million Btu to 38.7 million Btu per person. Energy consumption per capita in the OECD grows slightly faster, from 194.7 to 221.9 million Btu per person between 1990 and 2010.
Figure 14. OECD and Non-OECD Energy Consumption per Capita, 1970-2010

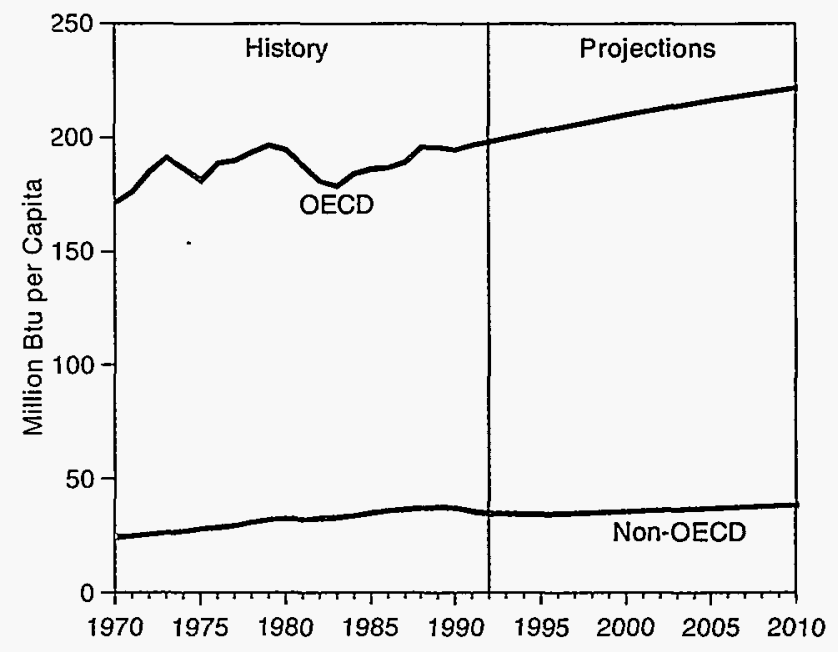

Sources: History: 1970-1979: Energy Information Administration (EIA), Office of Energy Markets and End Use, International Statistics Database. 1980-1992: ElA, International Energy Annual 1992, DOE/ ElA-0219(92) (Washington, DC, January 1994). Projections: ElA, World Energy Projection System (1995). Population: United Nations, World Population Prospects: The 1994 Revision Annex Tables (New York, NY, 1994), Tables A.1 and A.2.

\section{OECD Regional Trends}

Energy consumption in the OECD countries rose by 49 quadrillion Btu between 1970 and 1990 (Table 6). In the following two decades an additional growth of 55 quadrillion Btu is anticipated. Within the OECD, North America-led by the United States-accounts for more than half of total energy consumption. The North American share of energy consumption has trended downward since 1970. That trend is expected to continue through 2010, primarily because of expected slow growth in energy demand in the United States. The OECD Europe region ranks just behind the United States in terms of total energy consumed and should hold second place through 2010 , by that time consuming about three-quarters as much energy as is projected for the United States.

Energy consumption in the OECD Pacific region (which includes Japan, Australia, and New Zealand, along with the U.S. Territories) shows the fastest growth among the three OECD regions, both historically and in the projection period (Table 6). Consumption in the OECD Pacific region is expected to increase by 42 percent between 1990 and 2010, compared with a 27-percent increase in energy consumption for the OECD North America region over the same period. More rapid 
Table 6. OECD Energy Consumption by Region, 1970-2010

(Quadrillion Btu)

\begin{tabular}{|c|c|c|c|c|c|}
\hline \multirow[b]{2}{*}{ Region/Country } & \multirow[b]{2}{*}{1970} & \multirow[b]{2}{*}{1990} & \multirow[b]{2}{*}{2010} & \multicolumn{2}{|c|}{ Annual Percent Change } \\
\hline & & & & $1970-1990$ & $1990-2010$ \\
\hline Total OECD & 135.1 & 183.8 & 239.0 & 1.6 & 1.3 \\
\hline North America & 76.0 & 99.9 & 126.5 & 1.4 & 1.2 \\
\hline United States .. & 67.6 & 84.3 & 103.9 & 1.1 & 1.0 \\
\hline Europe $\ldots \ldots \ldots$. . & 44.7 & 60.9 & 79.8 & 1.6 & 1.4 \\
\hline Pacific $\ldots .$. & 14.3 & 23.0 & 32.6 & 2.4 & 1.8 \\
\hline Japan & 11.0 & 18.2 & 26.4 & 2.6 & 1.9 \\
\hline
\end{tabular}

Sources: History: Energy Information Administration (EIA), Office of Energy Markets and End Use, International Statistics Database; and International Energy Annual 1992, DOE/EIA-0219(92). Projections: ElA, World Energy Projection System (1995).

growth in OECD Pacific energy consumption is a result of higher economic growth in the region relative to the other OECD regions. GDP is projected to grow by 2.8 percent annually in the Pacific region, to $\$ 3,268$ billion (1985 U.S. dollars) between 1990 and 2010, while GDP in both North America and Europe grows more slowly, at 2.2 and 2.3 percent per year, respectively (Table 2 ).

In all the OECD regions, energy intensity declined steadily between 1970 and 1990 (Figure 15), although the decline in energy intensities has slowed in recent years. It is projected that the rate of improvement (decrease) in energy intensities will resume in coming years. The projected decline is the result of anticipated further technological advances that will improve energy

Figure 15. OECD Energy Intensities, 1970-2010

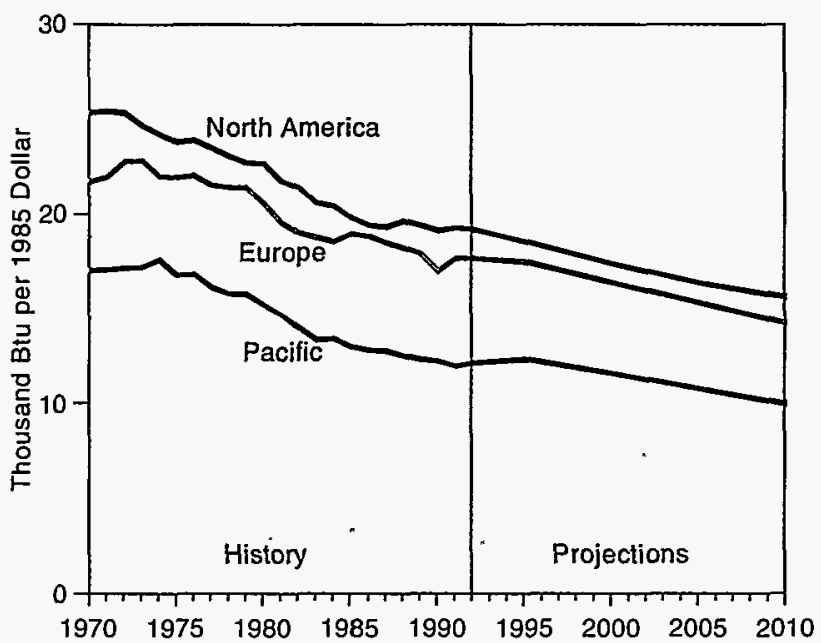

Sources: History: 1970-1979: Energy Information Administration (EIA), Office of Energy Markets and End Use, International Statistics Database. 1980-1992: EIA, International Energy Annual 1992, DOEI EIA-0219(92) (Washington, DC, January 1994). Projections: EIA, World Energy Projection System (1995). efficiency, as well as further structural change toward less energy-intensive sectors. However, lower energy costs and rising incomes could act to decelerate improvements in energy efficiency [2, p. 34]. OECD North America and OECD Europe, for the most part, have had historically similar energy intensity paths. The similarity is projected to persist through 2010, while energy intensity for the OECD Pacific region will remain below that of the other two OECD regions. Toward the end of the projection period, the differences narrow somewhat.

The narrowing difference in energy intensity within the OECD regions reflects, in part, changes in per capita energy consumption. While per capita consumption has been stable in North America, it has tended to rise elsewhere. The largest increases are in the OECD Pacific region (Figure 16). In part, they reflect a changing economic structure that favors energy-intensive industries, particularly in Australia. The increases also reflect rising standards of living, which lead to increased demand for personal transportation services and larger, more energy-intensive dwellings. In Japan, especially, it is expected that energy requirements per capita will grow through the projection period, as consumers buy more automobiles and better heated homes.

\section{Non-OECD Regional Trends}

Since 1970, energy growth in non-OECD countries has far exceeded that of the OECD. By 2010, non-OECD energy requirements are expected to nearly equal those of the OECD, whereas OECD consumption in 1970 was nearly twice that of the non-OECD regions (Table 4).

Highly diverse energy, income, and energy intensity trends are evident within the non-OECD regions. The EE/FSU countries have been in a state of economic 
Figure 16. OECD Energy Consumption per Capita, 1970-2010

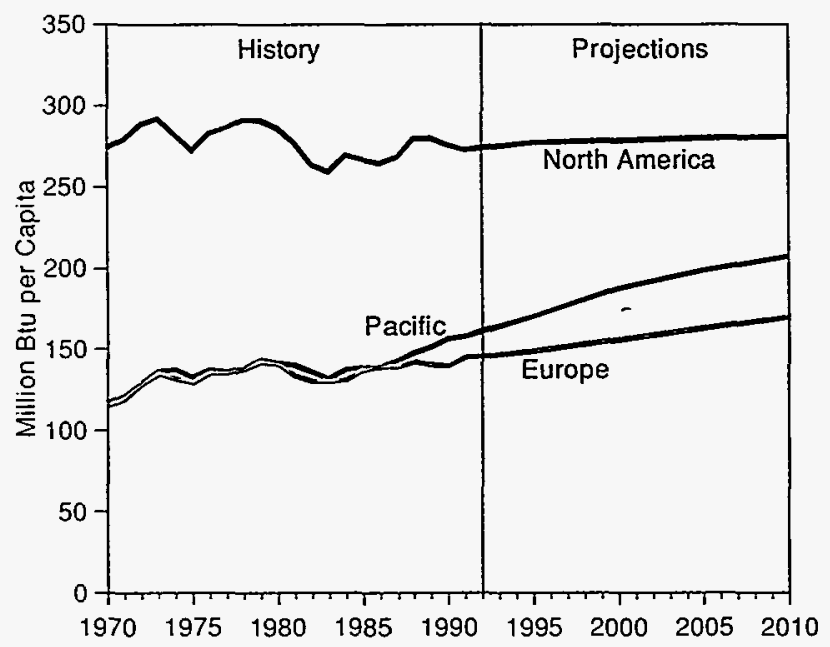

Sources: History: 1970-1979: Energy Information Administration (EIA), Office of Energy Markets and End Use, International Statistics Database. 1980-1992: ElA, International Energy Annual 1992, DOE/ EIA-0219(92) (Washington, DC, January 1994). Projections: EIA, World Energy Projection System (1995). Population: United Nations, World Population Prospects: The 1994 Revision Annex Tables (New York, NY, 1994), Tables A.1 and A.2.

collapse for several years. Between 1989 and 1992, average income fell by 31 percent and energy consumption by 17 percent (Figures 17 and 18). At the other extreme, non-OECD Asia (including China and India) experienced explosive growth, with income rising by more than 7 percent per year between 1980 and 1990 and energy growth at least matching that pace (Table 2). By 2010, non-OECD Asia is projected to account for almost one-half of all non-OECD energy consumption (Table 7). China alone is expected to account for almost 12 percent of world consumption in 2010, whereas its share was 6 percent in 1970 and 8 percent in 1990 (Tables $I$ and 7 ). The projections anticipate an increase of more than threefold in non-OECD energy consumption between 1970 and 2010 .

EE/FSU is expected to experience economic recovery by 2010, with energy consumption totaling about 75 quadrillion Btu-a level approximately equal to that attained in 1990. Consumption in China is expected to exceed 55 quadrillion Btu in 2010, nearly equal to the FSU's consumption level of 58 quadrillion Btu (Table 7). In 1970, China's consumption was only 40 percent that of the FSU. The assumptions about the path of energy intensity in China, which has one of the most rapidly growing economies in the world, critically affect the projections of that country's future energy consumption. If China's energy intensity is assumed to remain constant at its 1992 value through 2010, the resulting
Figure 17. Non-OECD Economic Growth, 1970-2010

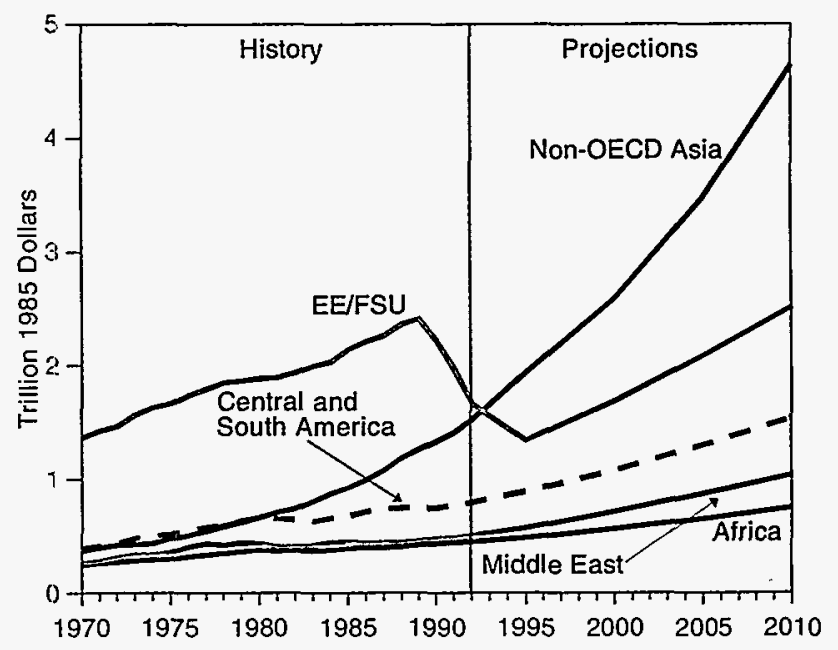

Sources: History: The WEFA Group, World Economic Service Historical Data (Bala Cynwyd, PA, July 1993), pp. 8.10-8.12. Projections: The WEFA Group, World Economic Outlook, Vol. 3 (Bala Cynwyd, PA, October 1994); and Energy Information Administration, World Energy Projection System (1995).

energy consumption in 2010 would be 100 quadrillion Btu--almost double the 55 quadrillion Btu projected in the Reference Case.

Energy consumption in the other non-OECD regionsthe Middle East, Africa, and Central and South America-appears comparatively flat relative to Asia and EE/FSU (Figure 18). However, the consumption

Figure 18. Non-OECD Energy Consumption by Region, 1970-2010

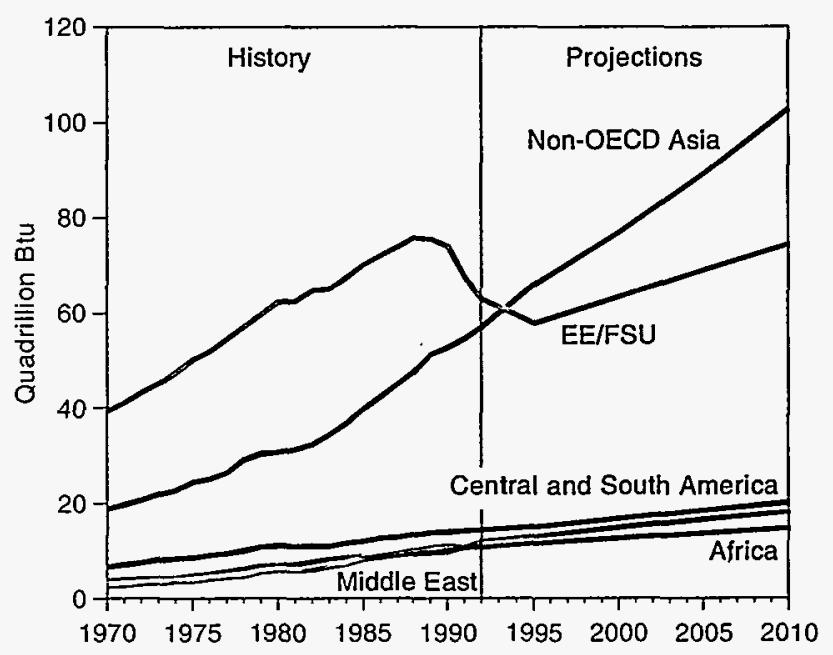

Sources: History: 1970-1979: Energy Information Administration (EIA), Office of Energy Markets and End Use, International Statistics Database. 1980-1992: EIA, International Energy Annual 1992, DOE/ EIA-0219(92) (Washington, DC, January 1994). Projections: EIA, World Energy Projection System (1995). 
Table 7. Non-OECD Energy Consumption by Region, 1970-2010

(Quadrillion Btu)

\begin{tabular}{|c|c|c|c|c|c|}
\hline \multirow[b]{2}{*}{ Region/Country } & \multirow[b]{2}{*}{1970} & \multirow[b]{2}{*}{1990} & \multirow[b]{2}{*}{2010} & \multicolumn{2}{|c|}{ Annual Percent Change } \\
\hline & & & & $1970-1990$ & $1990-2010$ \\
\hline Total Non-OECD $\ldots . . .$. & 71.7 & 161.8 & 232.7 & 4.2 & 1.8 \\
\hline EE/FSU $\ldots \ldots \ldots$ & 39.7 & 74.3 & 74.7 & 3.2 & 0.0 \\
\hline Former Soviet Union . & 29.0 & 58.0 & 58.4 & 3.5 & 0.0 \\
\hline Eastern Europe $\ldots$ & 10.7 & 16.3 & 16.2 & 2.1 & 0.0 \\
\hline Non-OECD Asia ... & 18.9 & 52.5 & 104.2 & 5.3 & 3.5 \\
\hline China ....... & 11.6 & 27.9 & 55.6 & 4.5 & 3.5 \\
\hline Middle East . & 2.9 & 11.3 & 18.4 & 7.0 & 2.5 \\
\hline Africa $\ldots \ldots \ldots \ldots \ldots$ & 3.6 & 9.8 & 14.6 & 5.1 & 2.0 \\
\hline Central and South America & 6.6 & 13.9 & 20.8 & 3.8 & 2.0 \\
\hline
\end{tabular}

Sources: History: Energy Information Administration (EIA), Office of Energy Markets and End Use, International Statistics Database; and International Energy Annual 1992, DOE/EIA-0219(92). Projections: ElA, World Energy Projection System (1995).

levels in these regions are, in fact, growing substantially over the 1970-2010 period. Consumption in the Middle East rose from 3 quadrillion Btu in 1970 to 13 quadrillion Btu in 1990; Africa's energy consumption rose from 4 to 10 quadrillion Btu; and consumption in Central and South America rose from 7 to 10 quadrillion Btu. By 2010, energy consumption in the Middle East is expected to grow to more than 18 quadrillion Btu, representing an average annual increase of about 3 percent over the projection period. Growth rates for Africa and for Central and South America are slightly lower, averaging 2 percent per year for both regions over the 1990-2010 period.

Key uncertainties regarding future energy demand growth rest on economic developments in the EE/FSU region and on trends in energy intensities in areas of the world with rapidly expanding economies. Energy prospects for the FSU are highly uncertain. The FSU is among the richest regions of the world in terms of energy resources, but the ability of FSU countries to develop their resources is uncertain, particularly during this time of economic and political transformation. It is assumed that FSU energy consumption will decline through 1995 and will not return to 1990 levels until 2010.

The rise in the EE/FSU energy intensity index is primarily the result of the political and economic changes occurring in the FSU, which have resulted in declining energy consumption in the FSU every year since 1989 [3, p. 118], with GDP declining even faster. Economic activity and energy consumption in the FSU are projected to resume positive growth beyond 1995, but the FSU (and Eastern Europe) will likely continue to be the world's most inefficient users of energy. Inefficiency in the EE/FSU region is the result of a past in which domestic energy prices were kept below world market prices. Artificially low energy prices encouraged development of an industrial base that uses energy very inefficiently. As a result, there is considerable room for improvement in the energy efficiency of economic activity in this part of the world.

Energy intensity trends are quite diverse in other non$O E C D$ regions (Figure 19). In Africa and the Middle East, energy intensity increased between 1970 and 1990,

Figure 19. Non-OECD Energy Intensities by Region, 1970-2010

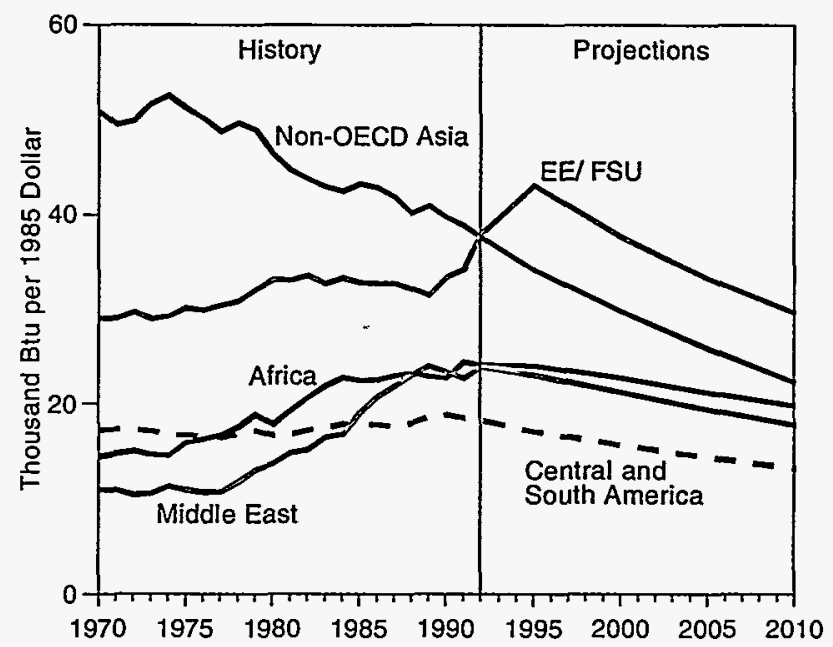

Sources: History: 1970-1979: Energy Information Administration (EIA), Office of Energy Markets and End Use, International Statistics Database. 1980-1992: EIA, International Energy Annual 1992, DOE/ EIA-0219(92) (Washington, DC, January 1994). Projections: EIA, World Energy Projection System (1995). 
primarily as a consequence of strong growth in industrial activity associated with the emergence of energyintensive industries. The IEO95 projections assume that the growth of energy-intensive industries in Africa and the Middle East will not outstrip overall economic development in future years, and that the experience in non-OECD Asia of declining energy intensities in the 1980s will persist through 2010.

Even with large expected increases in overall energy requirements in non-OECD regions, per capita energy consumption is not projected to rise substantially. While large increases in income and energy demand are projected, so too are large increases in population. Population trends in the non-OECD countries are dominated by Asia, which holds 53 percent of the world population [1, p. 5.9]. In non-OECD Asia, the population is projected to grow by 1.4 percent per year between 1990 and 2010 [4, pp. 24-31]. Africa also is projected to grow substantially-by 83 percent-over the projection period, from its current population of 633 million to 1.2 billion by 2010 . The lowest population growth rate among the non-OECD regions is projected for the EE/FSU, at 0.2 percent per year through the end of the projection period. Therefore, in this region, economic recovery and resulting increases in energy use will be reflected in increasing per capita energy consumption (Figure 20).

\section{Energy Use and Carbon Emissions}

In recent years, there has been growing concern over the increase in anthropogenic (human-induced) emissions of carbon and the impact such emissions may have on global warming. Approximately 75 percent of the world's carbon emissions are the result of combustion of fossil fuels for energy production [5, p. 98]. Since no emissions abatement technology is commercially available for carbon, emissions from combustion are directly related to fossil fuel consumption. Among the fossil fuels, coal has the most carbon per unit of energy, natural gas has the least, and petroleum is in the middle.

Countries faced with commitments to stabilize carbon emissions by 2000 at 1990 levels have few choices. ${ }^{3}$ Economic growth requires increases in energy consumption, although historically there is considerable variation in energy intensity among countries. "Carbon intensity" also varies among countries, depending on
Figure 20. Non-OECD Energy Consumption per Capita, 1970-2010

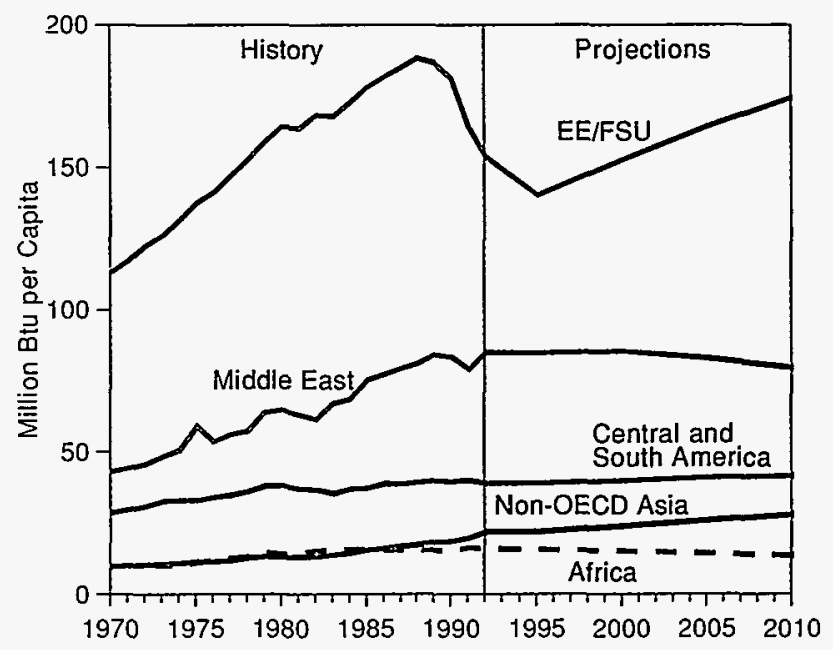

Sources: History: 1970-1979: Energy Information Administration (EIA), Office of Energy Markets and End Use, International Statistics Database. 1980-1992: EIA, International Energy Annual 1992, DOE/ EIA-0219(92) (Washington, DC, January 1994). Projections: EIA, World Energy Projection System (1995). Population: United Nations, World Population Prospects: The 1994 Revision Annex Tables (New York, NY, 1994), Tables A.1 and A.2.

the demand for different fuels and the type and availability of economical indigenous fuel supplies. Countries with low-cost indigenous supplies of coal or oil tend to be more "carbon intense" than countries that have the resources for economical hydroelectric power or access to nuclear power.

Over the past two decades, total carbon emissions from energy consumption rose by about 50 percent, trailing energy use, which rose by 64 percent (Figure 21). An important reason for the slower rise in carbon emissions was the development of nuclear power generation, primarily in the industrialized countries. Carbon emissions increase more slowly than energy use where there is movement from more carbon-intensive fuels (primarily coal) to less intensive ones (natural gas and renewables). Energy projections in this report imply continued growth in carbon emissions through 2010, and the rate of growth in emissions will continue to trail growth in energy, as the role of natural gas and renewable fuels expands. Total carbon emissions are projected to reach 8,092 million metric tons by 2010 (Table A9). The final outcome could be higher if, for example, the energy requirements of countries that are currently industrializing are underestimated. Converse-

\footnotetext{
${ }^{3}$ The United Nations Framework Convention on Climate Change (UNFCCC) went into force on March 21, 1994. The objective of the UNFCCC is to stabilize concentrations of greenhouse gases at a safe level. A number of industrialized countries are committed to returning greenhouse gas emissions to 1990 levels by 2000 .
} 
Figure 21. World Trends, 1970-2010

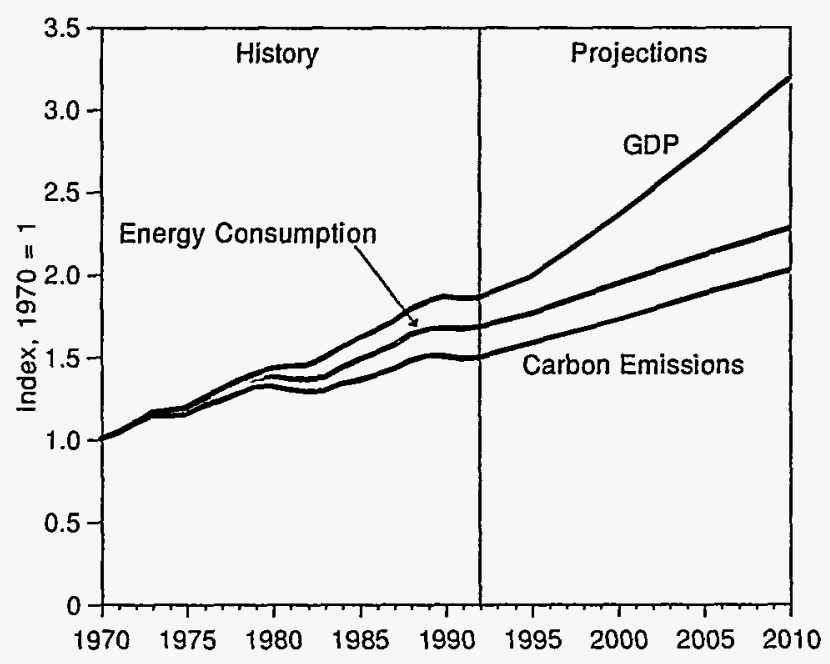

Sources: History: 1970-1979: Energy Information Administration (EIA), Office of Energy Markets and End Use, International Statistics Database. 1980-1992: EIA, International Energy Annual 1992, DOE/ ElA-0219(92) (Washington, DC, January 1994). Projections: World GDP: The WEFA Group, World Economic Outlook, Vol. 3 (Bala Cynwyd, PA, October 1994). Energy Consumption and Carbon Emissions: EIA, World Energy Projection System (1995).

ly, emissions could be lower if technological breakthroughs in the efficiency of energy-using equipment or the economical production of biofuels are achieved.

Since fossil fuels vary in carbon intensity per unit of energy provided, fuel mix is an important determinant of carbon emissions (Figure 22). Emissions from petroleum are expected to retain their dominant role over the next decades (Tables A10, A11, and A12). As countries progress toward positions of greater wealth, consumer demand for transportation fuels and electricity will expand. The alternatives to petroleum for transportation are limited by issues of cost and infrastructure. There is greater opportunity for switching from coal to natural gas in manufacturing and in electricity generation. Carbon emissions from gas are roughly half those from coal. During the period following the world oil crises of 1973 and 1979, switching from oil to coal in electric power generation and industry contributed to an increase in carbon emissions over what they would otherwise have been. In the future, however, natural gas is expected to play a more important role in the world's energy supply, because it is economical and clean-burning with respect to carbon emissions and other pollutants as well, including sulfur dioxide, nitrous oxide, and particulates.

From the 1970s through the 1980s, industrialized countries accounted for the majority of the world's carbon emissions (Figure 23). In the years after 1982, develop-
Figure 22. World Carbon Emissions by Fuel, 1970-2010

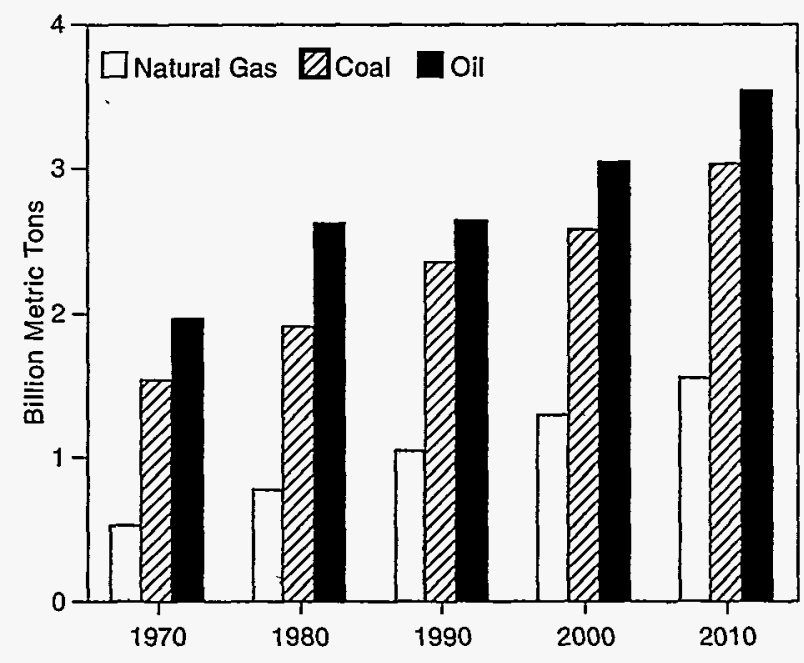

Sources: History: 1970-1979: Energy Information Administration (EIA), Office of Energy Markets and End Use, International Statistics Database. 1980-1992: ElA, International Energy Annual 1992, DOE/ EIA-0219(92) (Washington, DC, January 1994). Projections: EIA, World Energy Projection System (1995).

ing non-OECD countries accounted for a growing share of the emissions. That growth was interrupted by the collapse of the economies of the EE/FSU. As a result, energy consumption and carbon emissions dropped sharply (Figure 24). As these economies recover, energy consumption should rise, although the rise in carbon

\section{Figure 23. World Carbon Emissions by Region, 1970-2010}

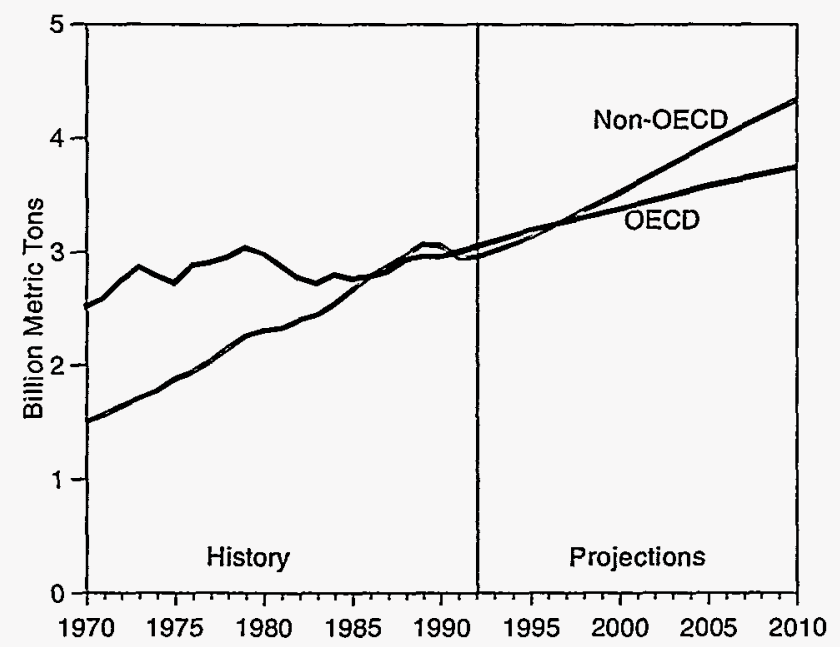

Sources: History: 1970-1979: Energy Information Administration (EIA), Office of Energy Markets and End Use, International Statistics Database. 1980-1992: EIA, International Energy Annual 1992, DOE/ EIA-0219(92) (Washington, DC, January 1994). Projections: ElA, World Energy Projection System (1995). 
Figure 24. Non-OECD Carbon Emissions, 1970-2010

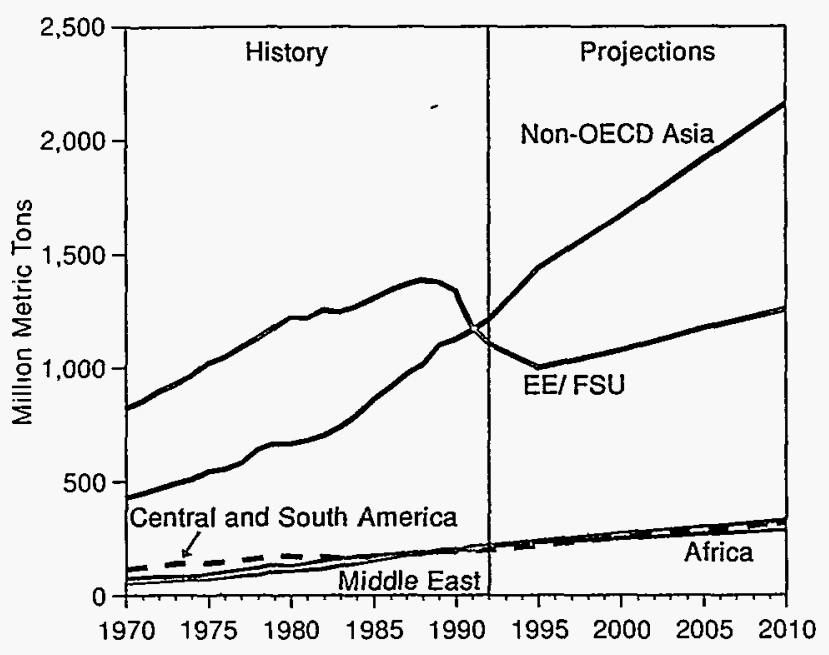

Sources: History: 1970-1979: Energy Information Administration (EIA), Office of Energy Markets and End Use, International Statistics Database. 1980-1992: EIA, International Energy Annual 1992, DOE/ EIA-0219(92) (Washington, DC, January 1994). Projections: EIA, World Energy Projection System (1995)

emissions may be slowed as industries are rebuilt with competitive technologies. On the other hand, as these countries attain greater wealth, consumer demand for products and services will also increase. Electrification and the rapid expansion of automobile ownership will lead to increased emissions. Moreover, as the world's least economically developed countries (in which largely unrecorded amounts of renewable biofuels such as wood and agricultural waste are commonly used) begin industrializing, net emissions of carbon are likely to increase; unless new renewable sources of energy supply can be tapped.

\section{Comparisons With Other Projections}

Many economic, technological, and political events and decisions will influence the future course of world energy markets. Unforeseen developments in, and reactions to, these and other influences make any projections of world energy markets highly uncertain. Possibly the greatest uncertainties concerning the world's economic and energy future concern developments in the EE/FSU and China. World energy prospects could vary considerably, depending on decisions by those countries about the nature and pace of political and economic reforms. Events in the Middle East and, to a lesser degree, decisions by the Organization of Petroleum Exporting Countries (OPEC) have caused unexpected changes in world oil markets in the past. The political situation in the Middle East continues to remain volatile.
Economic prospects and policy decisions by the industrial countries of the OECD and other newly industrialized countries, such as those in the Pacific Rim, add an additional element of uncertainty to world energy prospects. There is uncertainty as to the pace of future economic growth in the industrial world, the ability and willingness of industrialized nations to provide financial and technical assistance to the developing world, and decisions by the OECD and others concerning energy conservation, energy security, and the environment.

The manner in which analysts resolve these various uncertainties for purposes of forecast development can vary across organizations. To give further perspective to the projections presented here, this section includes a brief set of comparisons with other forecasts. The principal forecast comparisons involve those developed by the International Energy Agency (IEA), Petroleum Economics Limited (PEL), and Petroleum Industry Research Associates (PIRA). Compared with the IEO95 projections, two forecasts (IEA and PIRA) indicate higher levels of growth in energy demand over the next two decades (see Table 9). The PEL forecast projects the same level of growth as IEO95.

\section{Economic Growth Assumptions}

The differences in projected world energy consumption among the studies compared here result primarily from differences in expectations about the prospects for economic development in the non-OECD regions of the world (Table 8). Expectations regarding average annual growth rates for the OECD between 1990 and 2010 lie in a narrow range of 2.3 percent (PEL and IEO95) to 2.5 percent (IEA). Projections for global economic growth reflect a wider range-from 2.7 percent per year (PEL and IEO95) to 3.7 percent (for PIRA, whose projections extend only to 2005).

Although all the forecasts agree that non-OECD growth is likely to exceed OECD growth, they do not agree on the extent of that difference. The IEO95 projection assumes the slowest rate of growth for non-OECD areas: 3.4 percent per year. The IEA projects non-OECD growth at 4.8 percent per year, and PIRA assumes a rate of 4.9 percent (through 2005). Differences are even greater regarding expectations of development within non-OECD areas. All but IEA are pessimistic regarding the rate of recovery in FSU or FSU and Eastern Europe combined. The rates of growth in other regions are expected to be strong, with the IEA and PIRA most bullish on growth prospects in Asia. 
Table 8. Comparison of Economic Growth Assumptions, 1990-2010, by Region (Average Annual Percent Growth)

\begin{tabular}{|c|c|c|c|c|}
\hline Region/Country & JEO95 & IEA $^{\mathrm{a}}$ & PEL & PIRA $^{\mathrm{b}}$ \\
\hline OECD & 2.3 & 2.5 & 2.3 & 2.4 \\
\hline North America $\ldots \ldots \ldots \ldots \ldots \ldots$ & 2.2 & 2.5 & $2.3^{\mathrm{C}}$ & $2.5^{\mathrm{C}}$ \\
\hline Europe $\ldots \ldots \ldots \ldots \ldots \ldots \ldots \ldots$ & 2.3 & 2.3 & 2.1 & 2.2 \\
\hline Pacific $\ldots \ldots \ldots \ldots \ldots \ldots \ldots$ & 2.8 & 2.7 & $2.8^{\mathrm{d}}$ & $2.6^{\mathrm{d}}$ \\
\hline Non-OECD $\ldots \ldots \ldots \ldots \ldots \ldots \ldots$ & 3.4 & 4.8 & 4.2 & 4.9 \\
\hline EEIFSU $\ldots \ldots \ldots \ldots \ldots \ldots \ldots$ & 0.6 & 2.1 & 0.5 & 0.6 \\
\hline Former Soviet Union $\ldots \ldots \ldots \ldots \ldots$ & 0.1 & 1.3 & -0.3 & - \\
\hline Eastern Europe $\ldots \ldots \ldots \ldots \ldots \ldots$ & 2.2 & 3.6 & 1.6 & - \\
\hline Non-OECD Asia . & 6.1 & 6.6 & - & 6.8 \\
\hline China..... & 7.4 & 7.9 & 7.4 & 8.0 \\
\hline Other Asia & 5.4 & 6.0 & - & 5.0 \\
\hline Middle East & 3.9 & 3.4 & - & - \\
\hline Africa $\ldots \ldots \ldots \ldots \ldots \ldots \ldots$ & 2.8 & 3.7 & - & - \\
\hline Central and South America $\ldots \ldots \ldots \ldots$ & 3.7 & 3.7 & - & - \\
\hline Total World & 2.7 & 3.1 & 2.7 & 3.7 \\
\hline
\end{tabular}

${ }^{a}$ IEA growth rates are for the period $1992-2010$.

BPIRA growth rates are for the period 1990-2005.

CPEL and PIRA growth rates for North America include only the United States. IEO95 includes Mexico in North America.

${ }^{\mathrm{P} E L}$ and PIRA growth rates for Pacific include only Japan.

Notes: OECD = Organization for Economic Cooperation and Development. EE/FSU = Eastern Europe/Former Soviet Union.

Sources: IEO95: Energy Information Administration, World Energy Projection System (1995). IEA: International Energy Agency, World Energy Outlook 1995 (Paris, France, 1995). PEL: Petroleum Economics, Ltd., World Long-Term Oil and Energy Outlook to 2010 (London, United Kingdom, November 1994). PIRA: Petroleum Industry Research Associates, Inc., Annual Retainer Client Seminar--World and U.S. Oil (New York, NY, October 1994).

\section{Energy Consumption Growth}

All projections reviewed here assume that energy consumption will grow at a slower rate than economic growth over the forecast horizon. Thus, each forecast assumes that energy intensity will decline. The IEA forecast assumes that the energy intensity of economic activity will decline (improve) at a rate of 1.0 percent per year between 1992 and 2010. The IEO95 and PEL forecasts assume that the rate of decline in energy intensity for the world as a whole will be about 1.1 percent per year between 1990 and 2010. The PIRA study assumes an even greater improvement in energy intensity, about 1.6 percent per year between 1990 and 2005; however, the PIRA study couples this rate of improvement with the highest rate of world economic growth3.7 percent per year-compared with 2.7 percent per year in IEO95.

The IEO95 and PEL projections of overall energy growth are similar (Table 9), although the underlying components of the forecasts vary. PIRA and IEA project stronger overall growth in energy demand. The difference-in the range of 0.4 percent per year-implies a gain in energy consumption of about 42 quadrillion Btu beyond the level of 472 quadrillion Btu projected in the IEO95 Reference Case.

Projections regarding the components of energy supply vary more widely than projected total demand. The largest variations relate to the roles of natural gas and coal. IEO95 projects the lowest growth rate for natural gas over the entire period from 1990 to 2010, although IEA and PIRA project lower growth for gas between 1990 and 2000. IEA and PIRA project stronger growth for coal use than does IEO95. The smallest variation among projections involves future growth expectations for oil demand.

\section{World Oil Demand, Supply, and Prices}

The projections by DRI/McGraw-Hill (DRI) and NatWest Securities Limited (NWS), available for oil but not for total energy, are added to the oil market comparison presented in Table 10. The projections uniformly indicate rising demand for oil between now and 2010. By 2000, an increase of 9 to 12 million barrels per day in world demand is anticipated. For the following 
Table 9. Comparison of Energy Consumption Growth Rates, 1990-2010, by Fuel Type (Average Annual Percent Growth)

\begin{tabular}{|c|c|c|c|c|}
\hline Fuel Type & IEO95 & IEA $^{a}$ & PEL & PIRA $^{\mathrm{b}}$ \\
\hline \multicolumn{5}{|l|}{ Oil } \\
\hline $1990-2000$ & 1.5 & 1.7 & 1.5 & 1.7 \\
\hline $2000-2010$ & 1.5 & 2.1 & 1.5 & 2.0 \\
\hline $1990-2005$ & 1.5 & - & 1.5 & 1.8 \\
\hline$\ldots \ldots \ldots \ldots \ldots \ldots \ldots$ & 1.5 & 1.9 & 1.5 & - \\
\hline \multicolumn{5}{|l|}{ Natural Gas } \\
\hline $1990-2000$ & 2.1 & 1.6 & 2.3 & 1.4 \\
\hline $2000-2010$ & 1.8 & 3.2 & 2.1 & 3.8 \\
\hline $1990-2005$ & 2.1 & - & 2.3 & 2.2 \\
\hline $1990-2010$ & 2.0 & 2.5 & 2.2 & - \\
\hline \multicolumn{5}{|l|}{ Coal } \\
\hline $1990-2000$ & 0.9 & 1.6 & 1.0 & 1.6 \\
\hline $2000-2010$ & 1.6 & 2.3 & 1.3 & 3.3 \\
\hline $1990-2005$ & 1.2 & - & 1.2 & 2.2 \\
\hline$\ldots \ldots \ldots \ldots$ & 1.3 & 2.0 & 1.2 & - \\
\hline \multicolumn{5}{|l|}{ Nuclear } \\
\hline$\ldots \ldots \ldots \ldots \ldots \ldots$ & 1.6 & 2.2 & 2.2 & 1.6 \\
\hline$\ldots \ldots \ldots \ldots \ldots \ldots \ldots$ & 0.3 & 0.7 & 0.6 & 0.5 \\
\hline $1990-2005$ & 1.3 & 一 & 1.8 & 1.2 \\
\hline $1990-2010$ & 0.9 & 1.3 & 1.4 & 一 \\
\hline \multicolumn{5}{|l|}{ Other Energy } \\
\hline $1990-2000 \ldots \ldots \ldots \ldots \ldots \ldots \ldots$ & 2.2 & 3.7 & 2.7 & 2.8 \\
\hline $2000-2010 \ldots \ldots \ldots \ldots \ldots \ldots \ldots$ & 2.3 & 2.9 & 2.2 & 2.4 \\
\hline $1990-2005 \ldots \ldots \ldots \ldots \ldots \ldots \ldots \ldots$ & 2.2 & - & 2.6 & 2.7 \\
\hline $1990-2010 \ldots \ldots$ & 2.3 & 3.3 & 2.4 & - \\
\hline \multicolumn{5}{|l|}{ Total Energy } \\
\hline $1990-2000 \ldots \ldots \ldots \ldots \ldots \ldots \ldots$ & 1.5 & 1.7 & 1.6 & 1.7 \\
\hline $2000-2010 \ldots \ldots \ldots \ldots \ldots \ldots \ldots$ & 1.6 & 2.3 & 1.6 & 2.7 \\
\hline $1990-2005 \ldots \ldots \ldots \ldots \ldots \ldots \ldots$ & 1.6 & - & 1.7 & 2.0 \\
\hline $1990-2010 \ldots \ldots \ldots \ldots \ldots \ldots \ldots$ & 1.6 & 2.1 & 1.6 & - \\
\hline
\end{tabular}

aIEA growth rates are for the periods 1992-2000, 2000-2010, and 1992-2010.

bPIRA growth rates are for the periods 1990-2000, 2000-2005, and 1990-2005.

Sources: IEO95: Energy Information Administration, World Energy Projection System (1995). IEA: International Energy Agency, World Energy Outlook 1995 (Paris, France, 1995), Capacity Constraints Case. PEL: Petroleum Economics, Ltd., World Long-Term Oil and Energy Outlook to 2010 (London, United Kingdom, November 1994). PIRA: Petroleum Industry Research Associates, Inc., Annual Retainer Client Seminar-World and U.S. Oil (New York, NY, October 1994).

decade, a further increment of 10 million barrels per day is foreseen, with the total world demand for oil ranging between 87 and 95 million barrels per day, compared with current levels of about 67 million barrels per day.

Among the projections, the largest differences in outlook relate to the role of OPEC production as a component of total world supply. IEO95 foresees that most expansion in oil demand will be met by increases in OPEC production, with only modest increases in oil prices. Two forecasts see modest growth in OPEC production by 2000 but with very different price implications. PEL projects the increase in OPEC production to be only 3 million barrels per day by 2000 (less than 10 percent higher than current levels), while prices remain low. IEA projects OPEC output at 34 million barrels per day by 2000 (the IEO95 projection is 35 million barrels per day) but expects the highest price levels among the forecasts reported here. In 2010, DRI projects the lowest OPEC production and the highest oil prices in the context of a world oil market of 87 million barrels per day. 
Table 10. Comparison of World Oil Consumption, Production, and Price Projections, 2000 and 2010, by Region

\begin{tabular}{|c|c|c|c|c|c|c|}
\hline Projection & IEO95 ${ }^{\mathrm{a}}$ & IEA & PEL & PIRA $^{\mathrm{b}}$ & $\mathrm{DRI}^{\mathrm{b}}$ & NWS \\
\hline \multicolumn{7}{|l|}{ History: 1992} \\
\hline \multicolumn{7}{|l|}{ Oil Consumption (Million Barrels per Day) } \\
\hline Total World $\ldots \ldots \ldots \ldots \ldots$ & 66.7 & - & - & - & - & - \\
\hline OECD $\ldots \ldots \ldots \ldots \ldots \ldots$ & 40.6 & - & - & - & - & - \\
\hline EE/FSU $\ldots \ldots \ldots \ldots \ldots \ldots$ & 7.8 & - & - & - & - & - \\
\hline Rest of World $\ldots \ldots \ldots \ldots \ldots$ & 18.3 & - & - & - & - & - \\
\hline \multicolumn{7}{|l|}{ Oil Production (Million Barrels per Day) } \\
\hline Total World $\ldots \ldots \ldots \ldots \ldots \ldots$ & 66.7 & - & - & - & - & - \\
\hline OPEC $\ldots .$. & 29.1 & - & - & - & - & - \\
\hline EE/FSU $\ldots .$. & 9.2 & - & - & - & - & - \\
\hline Rest of World $\ldots \ldots \ldots \ldots \ldots \ldots$ & 28.4 & - & - & - & - & - \\
\hline World Oil Price (1993 Dollars per Barrel) ${ }^{c} \ldots$ & 18.70 & - & - & - & - & - \\
\hline \multicolumn{7}{|l|}{ Projections: 2000} \\
\hline \multicolumn{7}{|l|}{ Oil Consumption (Million Barrels per Day) } \\
\hline 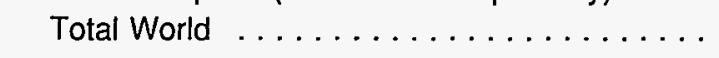 & 76.6 & 77.1 & 76.4 & 78.8 & 75.7 & 79.3 \\
\hline OECD $\ldots \ldots \ldots \ldots \ldots \ldots \ldots$ & 44.7 & 44.9 & 42.2 & 42.7 & 42.9 & 43.5 \\
\hline EE/FSU $\ldots \ldots \ldots \ldots \ldots \ldots \ldots$ & 6.1 & 7.3 & 6.4 & 7.1 & 4.5 & 6.6 \\
\hline Rest of World $\ldots \ldots \ldots \ldots \ldots \ldots$ & 25.8 & 24.9 & 27.8 & 29.0 & 28.3 & 29.2 \\
\hline \multicolumn{7}{|l|}{ Oil Production (Million Barrels per Day) } \\
\hline Total World $\ldots \ldots \ldots \ldots \ldots$ & 76.3 & 77.1 & 72.0 & 79.0 & 74.3 & 79.3 \\
\hline OPEC $\ldots \ldots \ldots \ldots \ldots \ldots$ & 34.8 & 34.0 & 31.6 & 30.6 & 34.4 & 37.1 \\
\hline EE/FSU $\ldots \ldots \ldots \ldots \ldots \ldots$ & 8.9 & 7.7 & 7.7 & 8.5 & 8.1 & 7.7 \\
\hline Rest of World $\ldots \ldots \ldots \ldots \ldots \ldots$ & 32.6 & 33.7 & 32.7 & 39.9 & 31.8 & 34.5 \\
\hline World Oil Price (1993 Dollars per Barrel) ${ }^{c}$ & 19.13 & 23.00 & 14.99 & 18.09 & 19.98 & 20.01 \\
\hline \multicolumn{7}{|l|}{ Projections: 2010} \\
\hline \multicolumn{7}{|l|}{ Oil Consumption (Million Barrels per Day) } \\
\hline 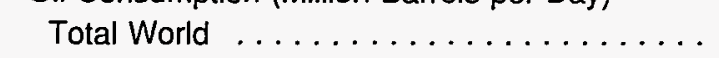 & 88.7 & 95.2 & 88.8 & - & 87.0 & - \\
\hline OECD $\ldots$. & 48.9 & 48.3 & 43.9 & - & 46.4 & - \\
\hline EE/FSU . . . . . & 9.2 & 10.1 & 7.4 & - & 5.0 & - \\
\hline Rest of World . . . . . . . . & 30.6 & 36.8 & 37.5 & - & 35.7 & - \\
\hline \multicolumn{7}{|l|}{ Oil Production (Million Barrels per Day) } \\
\hline Total World $\ldots \ldots \ldots \ldots \ldots \ldots$ & 88.4 & 95.2 & 83.0 & - & 85.1 & - \\
\hline OPEC $\ldots$ & 46.2 & 46.7 & 42.6 & - & 41.0 & - \\
\hline EE/FSU $\ldots .$. & 11.4 & 10.7 & 9.4 & - & 10.0 & - \\
\hline Rest of World $\ldots \ldots \ldots \ldots \ldots \ldots \ldots$ & 30.8 & 35.9 & 31.0 & - & 34.1 & - \\
\hline World Oil Price (1993 Dollars per Barrel) ${ }^{c} \ldots$ & 24.12 & 28.00 & 14.97 & - & 28.07 & - \\
\hline
\end{tabular}

a/EO95 includes Mexico in OECD. All other projections include Mexico in "Other."

bPIRA and DRI projections for EE/FSU production include only production from the former Soviet Union; production from Eastern Europe is included in "Other."

${ }^{\mathrm{C}} \mathrm{PEL}$ and NWS price projections are for Brent crude oil. PIRA price projections are for West Texas Intermediate crude oil. All other price projections are for average landed imports to the United States.

Notes: OECD = Organization for Economic Cooperation and Development. OPEC = Organization of Petroleum Exporting Countries.

Sources: IEO95: Energy Information Administration (EIA), World Energy Projection System (1995). IEA: International Energy Agency, World Energy Outlook 1995 (Paris, France, 1995), Capacity Constraints Case. PEL: Petroleum Economics, Ltd., World Long-Term Oil and Energy Outlook to 2010 (London, United Kingdom, November 1994). PIRA: Petroleum Industry Research Associates, Inc., Annual Retainer Client Seminar-World and U.S. Oil (New York, NY, October 1994). DRI: DRI/McGraw Hill, Oil Market Outlook (Lexington, MA, October 1994). NWS: NatWest Securities, Ltd., Oil Market Outlook (London, United Kingdom, November 1994). 
In contrast, IEA projects an increase of 13 million barrels per day in OPEC production, with an oil price of $\$ 28$ per barrel. Among all the forecasts, IEA's is the most bullish on total oil demand and the outlook for rising oil prices.

\section{References}

1. The WEFA Group. World Economic Outlook, Vols. 1 and 3. Bala Cynwyd, PA, October 1994.
2. International Energy Agency. World Energy Outlook 1994. Paris, France, 1994.

3. Energy Information Administration. International Energy Annual 1992. DOE/EIA-0219(94). Washington, DC, January 1994.

4. United Nations. World Population Prospects: The 1994 Revision Annex Tables. New York, NY, 1994.

5. International Energy Agency. Energy in Non-OECD Countries: Selected Topics 1991. Paris, France, 1992. 


\title{
The World Oil Market
}

\author{
World oil consumption grows steadily in the IEO95 forecast. \\ OPEC and non-OPEC oil reserves are sufficient to meet the rising demand \\ with moderate price increases.
}

Oil has been the dominant fuel used around the world to provide energy for many decades. In the recent past, concerns have been raised about the possibility that the world's oil resources were rapidly being depleted; however, those concerns have largely abated. OPEC nations have discovered sufficient additional reserves to readily meet the anticipated increases in demand over the next 15 years, and non-OPEC producers have expanded their resource base sufficiently to maintain a fairly steady level of production, which is expected to continue throughout the forecast period.

World oil consumption is projected to grow by 1.5 percent per year on average between 1990 and 2010, reaching a total of 89 million barrels per day at the end of the period (Table A3). Under alternative assumptions about world oil prices, total world consumption could be as low as 87 or as high as 95 million barrels per day (Figure 25). Despite falling oil prices in recent years, other fuels have remained competitive in the world's energy supply market. Thus, oil's share of total world energy consumption is expected to remain stable for the entire projection period, at about 40 percent of total primary fuel consumption (Figure 26 and Table A1).

Figure 25. World Oil Consumption, 1970-2010

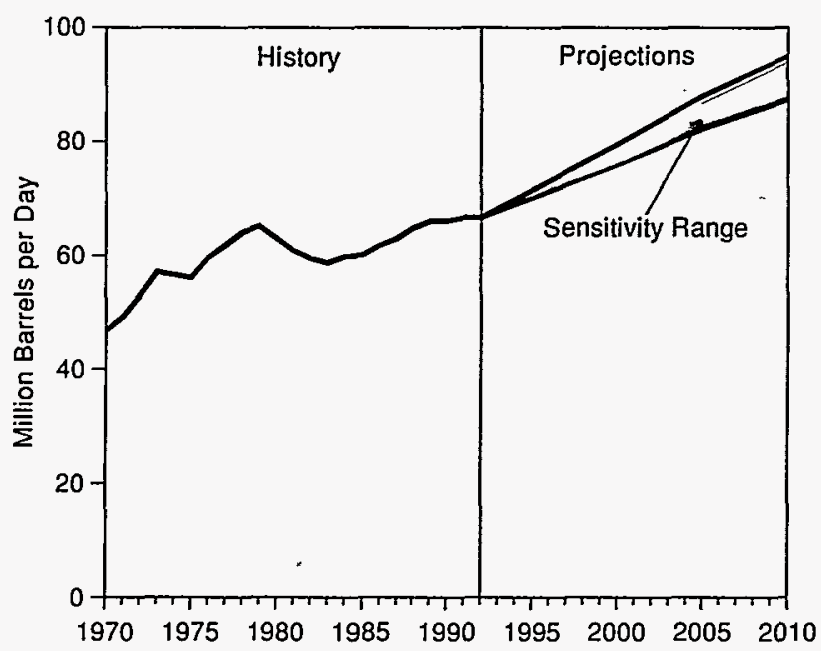

Sources: History: 1970-1979: Energy Information Administration (EIA), Office of Energy Markets and End Use, International Statistics Database. 1980-1992: EIA, International Energy Annual 1992, DOEI EIA-0219(92) (Washington, DC, January 1994). Projections: EIA, World Energy Projection System (1995).
Figure 26. World Oil Consumption Relative to All Other Energy Sources, 1970-2010

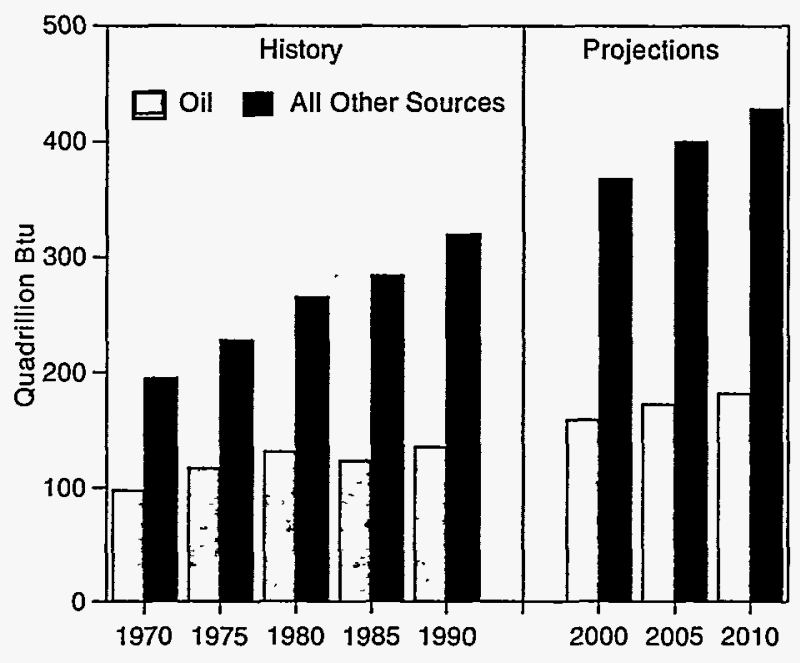

Sources: History: 1970-1979: Energy Information Administration (EIA), Office of Energy Markets and End Use, International Statistics Database. 1980-1992: ElA, International Energy Annual 1992, DOEJ EIA-0219(92) (Washington, DC, January 1994). Projections: EIA, World Energy Projection System (1995).

\section{Regional Variations in Consumption}

Oil remains the most important energy source in the majority of OECD countries, although the rate of growth in oil consumption in the OECD is lower than in developing countries, as is the case for total energy consumption (Figure 27). Oil consumption by OECD countries is expected to grow at about 1 percent per year, rising from 40 million barrels per day in 1990 to about 50 million barrels per day in 2010. Growth in non-OECD countries is about twice as rapid, with oil consumption rising from 27 to 40 million barrels per day in the 1990 to 2010 time period. In the rapidly developing non-OECD Asia region, which includes Pacific Rim countries and China, oil consumption grows by more than 4 percent per year. Consequently, OECD oil consumption-accounting for about 57 percent of world oil consumption in 1990-drops to a projected 55 percent of the world total in 2010 (Table A3).

Among OECD nations, the projected increase in oil consumption generally is in the neighborhood of 1 
Figure 27. World Oil Consumption by Region, 1970-2010

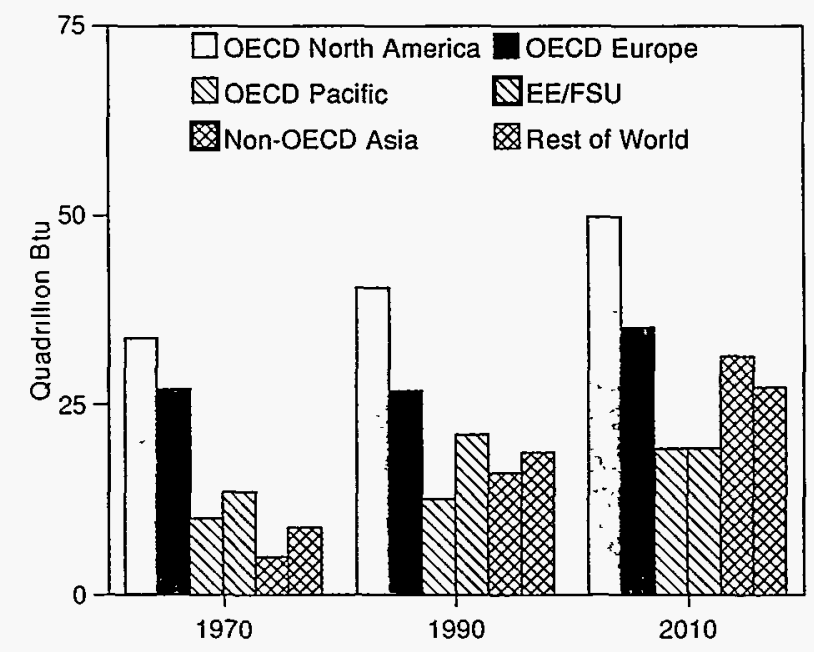

Sources: History: 1970-1979: Energy Information Administration $(E \mid A)$, Office of Energy Markets and End Use, International Statistics Database. 1980-1992: EIA, International Energy Annual 1992, DOE/ EIA-0219(92) (Washington, DC, January 1994). Projections: EIA, World Energy Projection System (1995).

percent per year. One exception is Mexico, where oil consumption is projected to grow by 2.3 percent per year between 1990 and 2010, as the nation's economy grows. In addition, oil's share of Mexico's total energy consumption is expected to increase from 73 percent in 1990 to 77 percent in 2010 . Throughout the forecast, oil accounts for more than one-half of all energy consumed in Italy and Japan, two nations that must import the major portion of their energy supplies.

Non-OECD nations present a more varied picture with respect to oil consumption. In regions of the world where economic growth is robust, principally in nonOECD Asia, growth in oil consumption ranges from 3 percent to over 4 percent per year between 1990 and 2010. In the regions with less dramatic projected economic growth (Middle East, Africa, and Central and South America), the growth rate for oil consumption is closer to 2 percent per year. The EE/FSU nations have suffered severe economic dislocations and, consequently, have experienced reductions in oil consumption in recent years, which may continue for a few more years. Growth in oil consumption for the EE/FSU countries is expected to resume by 2000 , with consumption levels in 2010 returning to those recorded in 1990.

The economic turmoil in the nations comprising the FSU has led to a dramatic drop in oil consumption in recent years, from 8.4 million barrels per day in 1990 to less than 5 million barrels per day in 1994 [1, p. 25]. The IEO95 forecast assumes that oil consumption in the FSU will decline a bit more over the next few years, approaching 4.3 million barrels per day in 1996-1997 and then gradually recovering to about 7.5 million barrels per day in 2010-still below its consumption in 1990. Oil's share of FSU energy consumption is expected to decrease from 30 percent in 1990 to 27 percent in 2010. There is no firm analytical basis for projecting a rate of economic recovery-and hence future oil consumption levels-in an economy that has suffered the trauma of a severe downturn with uncertain prospects for recovery. Therefore, as part of the assumptions underlying the different world oil price paths for IEO95, different assumptions have been made about the path of oil consumption in the FSU, with consumption assumed to be as high as 8.0 or as low as 7.1 million barsels per day in 2010 .

Since oil use is a key ingredient of economic growthparticularly in the crucial transportation sector where there currently is no significant competition for petroleum fuels - oil consumption is expected to increase most rapidly in countries with the fastest growing economies. The GDP growth rate for non-OECD Asia is assumed to average 6.1 percent per year between 1990 and 2010 , with the projected growth in oil consumption averaging 3.9 percent per year for the region over the same period (Table 2 and Table A3). Significant growth in petroleum use is expected both in the transportation sector-which is relatively underdeveloped at presentand in the residential and commercial sectors-where noncommercial fuels such as plants and animal wastes will be displaced by propane and other fuels as more advanced heating and cooking equipment is adopted.

The most rapid oil consumption growth is projected for the Other Asia country group of non-OECD Asia, the average annual increase is 4.3 percent from 1990 to 2010, as consumption rises from 5.3 million barrels per day in 1990 to 12.4 in 2010. In addition, oil's share of total energy consumption in the Other Asia country group increases from 45 percent in 1990 to 54 percent in 2010 (Table A1). China is also expected to continue to have rapid growth in economic activity, accompanied by rapid growth in energy consumption. China's GDP growth rate averages 7.4 percent per year between 1990 and 2010 (Table 2), and its oil consumption is expected to grow by 2.8 percent per year, from 2.3 to 4.0 million barrels per day (Table A3). 


\section{OPEC Reserves and Production Capacity Expansion}

The decade of the 1960s saw considerable oil exploration activity, which resulted in the addition of almost 310 billion barrels of crude oil reserves worldwide. (The reserves referred to in this section are proven reserves, that is, crude oil that is recoverable using present technology at current market prices.) The OPEC nations accounted for more than 60 percent of the additions, of which almost 82 percent were concentrated in the Persian Gulf. During the high oil price environment of the 1970s and early 1980s, most of the oil investment was in the downstream sector, with negligible additions to reserves. However, in the latter part of the 1980s, more than 350 billion barrels of crude oil reserves, an unprecedented amount, were added worldwide. Unlike the 1960s, however, when substantial additions were realized by both OPEC and non-OPEC nations, the additions during the late 1980 s were predominantly by the OPEC nations (almost 94 percent of the total). Over the 30-year period from 1960 through 1990, more than 78 percent of the additions to worldwide crude oil reserves were by the member nations of OPEC, and more than 85 percent of the OPEC additions were in the Persian Gulf region (Figure 28).

Figure 28. Additions of Crude Oil Proven Reserves by Decade, 1960-1990

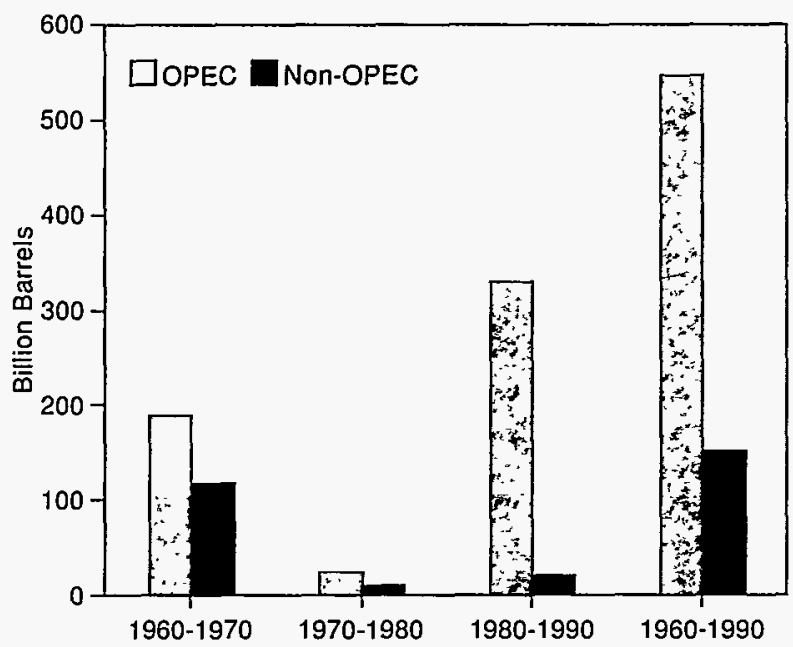

Source: International Petroleum Encyclopedia 1994, Vol. 27 (Tulsa, OK: PennWell Publishing, 1994).

Considering the substantive additions to OPEC crude oil reserves, it might be natural to assume that there were also dramatic increases in OPEC crude oil production. Such has not been the case. Although OPEC crude oil production has been increasing steadily in recent years, it still falls below its 1980 level even today. On the other hand, crude oil production from non-OPEC suppliers has seen a two-decade increase of more than two-thirds. The growth of non-OPEC supply between 1973 and 1980 was largely attributable to three areas: the Alaska North Slope, Mexico, and the North Sea. Since 1980, the trend in non-OPEC supply has been increasingly toward geographic dispersion, with particular supply potential exhibited in the developing countries. This two-decade growth in non-OPEC supply no doubt played a significant role in the erosion of OPEC's market share between 1973 and the mid-1980s. In addition to the unanticipated resilience of non-OPEC supply, OPEC's diminished market share during this period was also the result of the price-induced drop in world oil consumption, as well as the conscious decision by Persian Gulf producers to reduce output in an effort to maintain higher prices.

By the mid-1980s, OPEC market share had dropped below 30 percent. In the past several years, however, OPEC's share has grown to more than 40 percent. To understand the increase in the OPEC market share, it is instructive to compare OPEC and non-OPEC supply potential in terms of their reserves-to-production $(R / P)$ ratios. The $R / P$ ratio is one of the variables looked at by oil industry analysts to evaluate field development plans. It is also used as a measurement for assigning value to reserves. The difference between OPEC and non-OPEC $R / P$ ratios is substantial. Based on 1990 crude oil production levels, OPEC as a group has an $R / P$ ratio of 90 years, with the highest ratios concentrated in the Persian Gulf region. On the other hand, the $R / P$ ratio for non-OPEC producers is only 17 years (Table 11).

Table 11. Reserves and Production Measures for OPEC and Non-OPEC Producers

\begin{tabular}{|c|c|c|c|c|}
\hline Measure and Region & 1960 & 1970 & 1980 & 1990 \\
\hline \multicolumn{5}{|c|}{ Proven Reserves (Billion Barrels) } \\
\hline OPEC $\ldots \ldots \ldots$ & 217.7 & 408.1 & 433.8 & 765.0 \\
\hline Non-OPEC . . . . . . & 84.3 & 203.3 & 214.7 & 236.6 \\
\hline \multicolumn{5}{|c|}{ Production (Million Barrels per Day) } \\
\hline OPEC & 8.7 & 22.8 & 26.8 & 32.2 \\
\hline Non-OPEC . & 12.4 & 22.2 & 32.8 & 37.1 \\
\hline \multicolumn{5}{|c|}{ Reserves-to-Production Ratio (Years) } \\
\hline OPEC $\ldots \ldots$ & 68 & 49 & 44 & 90 \\
\hline Non-OPEC . . . . . . & 19 & 25 & 18 & 17 \\
\hline
\end{tabular}

Source: International Petroleum Encyclopedia 1994, Vol. 27 (Tulsa, OK: PennWell Publishing Co., 1994). 
With the wide disparity between OPEC and non-OPEC $R / P$ ratios, it is logical to assume that most production capacity expansion in the mid- to long term will be in the OPEC member nations, especially those in the Persian Gulf region. In fact, a compilation of official plans and announcements by OPEC member nations has expected additions to OPEC crude oil production capacity of at least 10 million barrels per day by the turn of the century [2, p. 23]. Such plans are consistent with the anticipated vigorous growth in oil demand (especially in the newly industrialized countries of the Pacific Rim region) and with the expectation that nonOPEC production will peak before the end of the decade.

The IEO95 price projections assume that the OPEC countries with large reserves that can be exploited at relatively low cost will have the greatest influence on future oil market conditions. It is assumed that OPEC nations will achieve sufficient revenue to expand production capacity as necessary to meet growing demand. Table 12 shows the additions to OPEC production capacity required to balance the world oil market over the forecast period.

Given the increasing levels of OPEC production expected over the forecast period, it is interesting to show the effect of such production on the OPEC reserve picture. The question is often asked, "When is OPEC going to run out of oil?" Figure 29 shows what happens to OPEC reserves under the Reference Case production profile assuming (1) no additions to OPEC reserves over the forecast period, (2) minimal additions to OPEC

\section{Figure 29. OPEC Oil Reserves in the Base Case, 1995-2010}

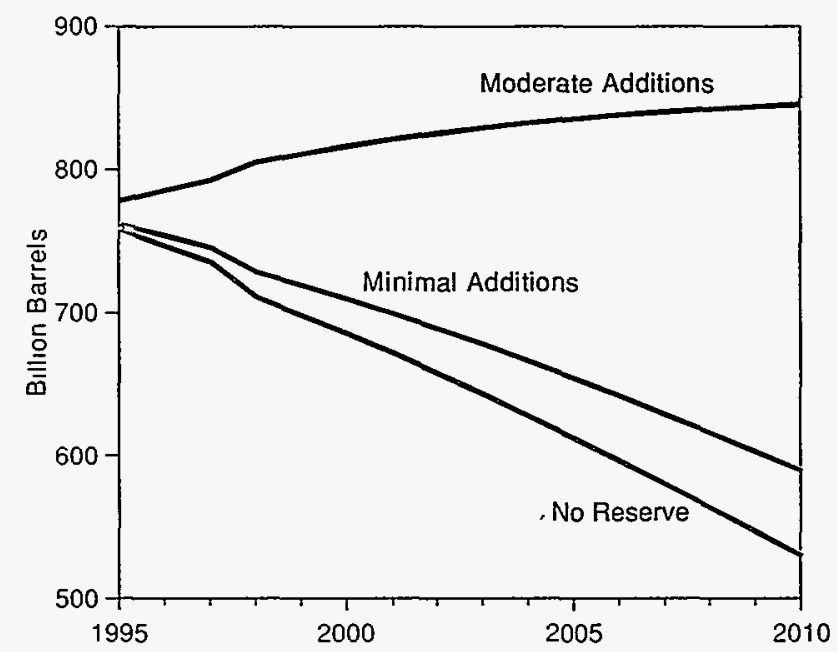

Sources: Energy Information Administration (EIA), National Energy Modeling System, International Energy Module (1995). reserves over the forecast period (as occurred during the 1970s), and (3) moderate building of reserves over the forecast period (as occurred during the 1960s). Even if OPEC members did not add a single barrel to their reserves, only about one-third of their current reserves would be used up by the year 2010. If OPEC were able to add to their reserves annually at a moderate rate (similar to that of the 1960s), total reserves would grow, despite the outlook for a significant increase in demand for (and production of) OPEC oil.

\section{Non-OPEC Oil Production Potential}

Throughout the projection period, oil production in non-OPEC countries increases gradually. The supply potential of this group is quite diverse, ranging from countries whose mature fields are in decline to those that are just beginning to produce significant volumes of oil [3].

When the IEO95 production profiles are compared with the projections in the International Energy Outlook 1994 (IEO94), several noteworthy differences emerge:

- U.S. production does not decline as severely in the IEO95 projections, and the production recovery near the end of the forecast period is more robust, both because of a more optimistic drilling outlook and because technological progress has expanded the economically recoverable oil base.

- North Sea production peaks earlier in IEO95, and the ensuing production decline is more severe, as large, older fields mature and low oil prices make the development of the expensive North Sea area less attractive.

- The former Soviet Union does not rebound as quickly in IEO95 from its current, precipitous production decline, because the anticipated influx of Western capital and technology has been impeded by the Russian bureaucracy, and because of concerns about resource ownership issues.

- The production outlook for the developing countries of Central and South America is more optimistic in IEO95, due to a more optimistic outlook for exploration in Argentina and Brazil and greater confidence in the prospects for political stability in the region.

The net effect of these differences is that IEO95 nonOPEC production estimates are 800,000 barrels per day below comparable IEO94 Reference Case estimates for the year 2000,600,000 barrels per day above for the year 2005, and 100,000 barrels per day below for the year 2010 . 
Table 12. World Oil Production Capacity Assumptions by Region, 1990-2010 (Million Barrels per Day)

\begin{tabular}{|c|c|c|c|c|c|c|c|c|c|c|c|}
\hline \multirow[b]{3}{*}{ Region/Country } & \multirow{2}{*}{\multicolumn{2}{|c|}{ History }} & \multicolumn{9}{|c|}{ Projections } \\
\hline & & & \multicolumn{3}{|c|}{2000} & \multicolumn{3}{|c|}{2005} & \multicolumn{3}{|c|}{2010} \\
\hline & \multirow{2}{*}{$\frac{1990}{27.8}$} & \multirow{2}{*}{\begin{tabular}{|l|}
1992 \\
27.2
\end{tabular}} & \multirow{2}{*}{\begin{tabular}{|c|}
$\begin{array}{c}\text { Reference } \\
\text { Case }\end{array}$ \\
37.5
\end{tabular}} & $\begin{array}{r}\text { Sensi } \\
\text { Rar }\end{array}$ & $\begin{array}{l}\text { tivity } \\
\text { gge }\end{array}$ & $\begin{array}{c}\text { Reference } \\
\text { Case }\end{array}$ & $\begin{array}{r}\text { Sensi } \\
\text { Ran }\end{array}$ & tivity & $\begin{array}{c}\text { Reference } \\
\text { Case }\end{array}$ & $\begin{array}{r}\text { Sensi } \\
\text { Ran }\end{array}$ & $\begin{array}{l}\text { tivity } \\
\text { ige }\end{array}$ \\
\hline$\ldots \ldots \ldots \ldots \ldots \ldots \ldots$ & & & & 35.0 & 41.8 & 42.1 & 36.8 & 45.5 & 46.5 & 39.2 & 49.1 \\
\hline Persian Gulf & 18.6 & 17.7 & 26.8 & 25.2 & 29.5 & 30.9 & 27.2 & 33.2 & 35.0 & 30.0 & 36.6 \\
\hline $\operatorname{Iran} \ldots \ldots \ldots \ldots \ldots$ & 3.2 & 3.6 & 4.3 & 4.2 & 4.7 & 5.0 & 4.5 & 5.4 & 5.4 & 4.9 & 5.7 \\
\hline$\ldots \ldots \ldots \ldots \ldots$ & 2.2 & 0.4 & 4.4 & 4.0 & 5.1 & 5.4 & 4.6 & 6.0 & 6.4 & 5.5 & 6.6 \\
\hline$\ldots \ldots \ldots \ldots \ldots$ & 1.7 & 1.1 & 2.9 & 2.8 & 3.2 & 3.6 & 3.1 & 3.9 & 4.2 & 3.5 & 4.6 \\
\hline Qatar .............. & 0.5 & 0.4 & 0.6 & 0.5 & 0.7 & 0.6 & 0.5 & 0.7 & 0.6 & 0.5 & 0.6 \\
\hline Saudi Arabia $\ldots \ldots \ldots \ldots$ & 8.5 & 9.6 & 11.5 & 10.8 & 12.5 & 12.8 & 11.5 & 13.5 & 14.1 & 12.3 & 14.6 \\
\hline United Arab Emirates ...... & 2.5 & 2.6 & 3.1 & 2.9 & 3.3 & 3.5 & 3.0 & 3.7 & 4.3 & 3.3 & 4.5 \\
\hline Other OPEC $\ldots \ldots \ldots \ldots$ & 9.2 & 9.5 & 10.7 & 9.8 & 12.3 & 11.2 & 9.6 & 12.3 & 11.5 & 9.2 & 12.5 \\
\hline Algeria $\ldots \ldots \ldots \ldots \ldots$ & 1.4 & 1.3 & 1.5 & 1.4 & 1.8 & 1.3 & 1.0 & 1.5 & 1.1 & 0.7 & 1.3 \\
\hline Gabon $\ldots \ldots \ldots \ldots \ldots$ & 0.3 & 0.3 & 0.3 & 0.3 & 0.4 & 0.3 & 0.2 & 0.3 & 0.3 & 0.2 & 0.3 \\
\hline Indonesia $\ldots \ldots \ldots \ldots \ldots$ & 1.5 & 1.7 & 1.4 & 1.2 & 1.5 & 1.1 & 0.9 & 1.3 & 1.0 & 0.7 & 1.2 \\
\hline Libya $\ldots \ldots \ldots \ldots \ldots \ldots$ & 1.6 & 1.6 & 1.8 & 1.6 & 2.2 & 2.1 & 1.8 & 2.3 & 2.0 & 1.6 & 2.2 \\
\hline Nigeria $\ldots \ldots \ldots \ldots \ldots \ldots$ & 1.8 & 2.0 & 2.4 & 2.3 & 2.7 & 2.6 & 2.3 & 2.8 & 2.8 & 2.4 & 3.0 \\
\hline Venezuela & 2.6 & 2.6 & 3.3 & 3.0 & 3.7 & 3.8 & 3.4 & 4.1 & 4.3 & 3.6 & 4.5 \\
\hline Non-OPEC $\ldots \ldots \ldots \ldots \ldots$ & 41.8 & 40.2 & 41.1 & 37.5 & 44.8 & 42.1 & 35.8 & 45.9 & 42.3 & 34.5 & 45.6 \\
\hline OECD & 20.1 & 20.6 & 20.3 & 18.4 & 21.5 & 19.7 & 16.6 & 21.1 & 19.4 & 15.5 & 21.1 \\
\hline United States & 9.7 & 9.7 & 8.2 & 7.3 & 8.6 & 8.2 & 6.6 & 8.9 & 8.6 & 6.4 & 9.5 \\
\hline Canada .... & 2.0 & 2.1 & 2.4 & 2.2 & 2.5 & 2.6 & 2.1 & 2.7 & 2.5 & 2.0 & 2.7 \\
\hline Mexico . . & 3.0 & 3.1 & 3.2 & 3.0 & 3.4 & 3.3 & 2.9 & 3.5 & 3.3 & 2.8 & 3.5 \\
\hline Australia . & 0.7 & 0.6 & 0.7 & 0.5 & 0.8 & 0.6 & 0.4 & 0.7 & 0.5 & 0.3 & 0.6 \\
\hline North Sea ... & 4.2 & 4.6 & 5.3 & 4.9 & 5.6 & 4.6 & 4.2 & 4.8 & 4.2 & 3.7 & 4.4 \\
\hline Other OECD & 0.5 & 0.5 & 0.5 & 0.5 & 0.6 & 0.4 & 0.4 & 0.5 & 0.3 & 0.3 & 0.4 \\
\hline EE/FSU $\ldots \ldots \ldots \ldots \ldots \ldots$ & 11.8 & 9.3 & 8.0 & 7.5 & 8.8 & 9.6 & 8.4 & 10.9 & 11.1 & 9.3 & 11.7 \\
\hline Former Soviet Union . & 11.5 & 9.1 & 7.8 & 7.3 & 8.5 & 9.4 & 8.3 & 10.7 & 10.9 & 9.2 & 11.5 \\
\hline Eastern Europe ... & 0.3 & 0.2 & 0.2 & 0.2 & 0.3 & 0.2 & 0.1 & 0.2 & 0.2 & 0.1 & 0.2 \\
\hline Non-OECD Asia $\ldots \ldots \ldots \ldots$ & 4.5 & 4.5 & 5.2 & 4.8 & 5.8 & 5.5 & 4.7 & 5.9 & 5.0 & 4.1 & 5.4 \\
\hline China $\ldots \ldots \ldots \ldots \ldots$ & 2.8 & 2.8 & 3.1 & 2.9 & 3.4 & 3.4 & 3.0 & 3.6 & 3.2 & 2.7 & 3.4 \\
\hline Other Asia $\ldots \ldots \ldots \ldots$ & 1.7 & 1.7 & 2.1 & 1.9 & 2.4 & 2.1 & 1.7 & 2.3 & 1.8 & 1.4 & 2.0 \\
\hline Middle East $\ldots \ldots \ldots \ldots \ldots$ & 1.4 & 1.5 & 2.0 & 1.8 & 2.3 & 2.0 & 1.7 & 2.3 & 1.8 & 1.5 & 2.0 \\
\hline Africa $\ldots \ldots \ldots \ldots \ldots \ldots$ & 1.8 & 1.9 & 2.1 & 1.8 & 2.5 & 2.0 & 1.5 & 2.2 & 1.9 & 1.4 & 2.1 \\
\hline Central and South America... & 2.2 & 2.4 & 3.5 & 3.2 & 3.9 & 3.3 & 2.9 & 3.5 & 3.1 & 2.7 & 3.3 \\
\hline Total World . & 69.6 & 67.4 & 78.6 & 72.5 & 86.6 & 84.2 & 72.6 & 91.4 & 88.8 & 73.7 & 94.7 \\
\hline
\end{tabular}

Notes: OPEC $=$ Organization of Petroleum Exporting Countries. OECD = Organization for Economic Cooperation and Development. EE/FSU = Eastern Europe/Former Soviet Union. Capacity is defined as maximum sustainable production capacity adjusted to reflect current operable capacity in selected countries. Production includes crude oil, natural gas liquids, refinery gains, hydrogen, and other hydrocarbons. Totals may not equal sum of components due to independent rounding.

Sources: History: Energy Information Administration (EIA), Energy Markets and Contingency Information Division. Projections: EIA, Office of Integrated Analysis and Forecasting, "DESTINY" International Energy Forecast Software (1995). 
In the IEO95 forecast, North Sea production peaks in 1996 at more than 6 million barrels per day. Over the past decade, Norway has emerged as the major oil producer in Western Europe. At the 1996 peak, Norwegian production should exceed 3 million barrels per day. Although there is still extensive production potential in Norway's North Sea fields, annual declines of about 100,000 barrels per day are expected as some of the larger and older fields mature. The production potential in the United Kingdom sector of the North Sea is not as great, and the annual declines from the 1996 peak of 2.8 million barrels per day could exceed 200,000 barrels per day. With so much untapped potential still available in the North Sea, new field developments could keep pace with declines if the price environment were favorable.

Non-OPEC Persian Gulf countries are expected to increase production over the projection period. In Oman, horizontal drilling is being used to improve production, and the use of enhanced oil recovery techniques is continuing. By the end of the decade, Oman is expected to expand its present output by almost 200,000 barrels per day. A 2-month civil war has somewhat dampened the previously optimistic oil production outlook for Yemen. Expansion of its current output by about 150,000 barrels per day now seems to be a realistic expectation by the late 1990s. Through advanced extraction technologies, Syria is expected to increase production slightly in the near term; but since output from some of the larger fields is declining, the increase is not likely to continue beyond the late 1990s.

In the Far East, oil production is expected to increase in the near term, then remain flat as the decade draws to a close. India is expected to increase its present output by at least 125,000 barrels per day over the next 3 years, but it is not anticipated that India can maintain such production levels for the remainder of the 1990s unless the investment climate for foreign companies improves. The most substantial long-term increases could come from the Philippines and Vietnam. Deep-water fields offshore from the Philippines have shown great promise, and estimates as high as 200,000 barrels per day have been made for production increases by the end of the decade. Similarly, there is considerable optimism about the long-term oil production potential for Vietnam. While the output of most Far Eastern producers is expected to decline after 2000 because of decreased production activity from mature fields, Vietnam is expected to keep on building up its production capacity well into the following decade, and production could approach 500,000 barrels per day by the turn of the century. Later in the projection period, Bangladesh and Mongolia are expected to be new producers. A slight near-term increase in Australia's current oil output of
500,000 to 600,000 barrels per day is expected, but a period of rather steep production declines is anticipated as the decade draws to a close. Offshore exploration in Australian waters over the past few years has yielded important natural gas discoveries but not much oil.

In Central and South America, both Colombia and Peru are expected to double their current production levels by the end of the 1990s, with steadily increasing production from developing fields as well as new production. Both countries are expected to continue encouraging significant multinational investment in their oil sectors. By 2000 , Colombia should join the relatively short list of producers whose output exceeds 1 million barrels per day, while Peru's output should expand to more than 200,000 barrels per day. In the same time frame, Brazilian oil production is also expected to reach 1 million barrels per day. However, before the October 1994 presidential election, the Brazilian government limited foreign investments in the oil sector, which has impeded the development of an area with enormous production potential. Ecuador, no longer a member of OPEC, is expected to increase its output by about 100,000 barrels per day by the end of the decade as its production capacity expands.

Non-OPEC producers in Africa promise only modest increases by the end of the decade-with only Angola, Congo, and Tunisia stepping up their current levels of output as a result of expected development of recent discoveries. Because of the absence of any major new oil finds, combined with normal declines from existing fields, decreases in output are expected in Cameroon, Egypt, and Zaire; but these decreases should not completely offset the increases from other countries on the continent. Beyond 2000, some increases might also be expected from such new African producers as Chad, the Ivory Coast, Equatorial Guinea, Somalia, South Africa, and the Sudan.

North American production is expected to continue to fall. Canada, however, should gradually increase its production over the projection period-primarily because of favorable tax provisions that encourage marginal production; the production of synthetic crude oil from its tar sands, which becomes increasingly economical over the projection period; and additional production of natural gas liquids. However, Canada's modest increases are not likely to be enough to offset the continued decline expected in the United States. Offshore U.S. discoveries in the Gulf of Mexico and incremental Alaskan production from the Cook inlet field are expected to slow the decline but not stop it. The availability of capital remains Mexico's greatest challenge in exploiting its substantial resource base. 
Some progress has been made toward allowing privatization and encouraging foreign investment in Mexican oil projects. Without a major infusion of capital, however, Mexican production is not expected to increase substantially beyond its current 3.1 million barrels per day throughout the projection period.

The Reference Case non-OPEC production estimates presented in this outlook are based on such parameters as the number of exploration wells, finding rates, reserve-to-production ratios, and advances in extraction technology. The ranges are based on the differences in world oil price projections. By the end of the projection period, the range of non-OPEC supply varies between 39.5 and 43.6 million barrels per day. The two primary contributors to the magnitude of this uncertainty range are the projections associated with the United States (a range of 6.4 to 9.5 million barrels per day in 2010) and the former Soviet Union (a range of 9.2 to 11.5 million barrels per day in 2010).

\section{World Oil Prices}

The world oil price has declined in recent years, and it is currently near its 1970 level in real terms. The dramatic price increases of the 1970s and early 1980s have largely been reversed. The combination of enhanced oil production capacity, end-use technologies that are more efficient in their use of oil, and shifts from oil to other energy sources for some purposes has resulted in strong downward pressure on prices, even as the worldwide demand for oil has continued to increase. Absent any major political event that would affect oil prices, they are expected to remain stable over the next few years.

Among oil market analysts, there are currently two major views on the future of oil prices over the next 15 years. One group expects a rise in prices after 2000, as the expansion of production capacity is moderated by limits to capital availability and by other OPEC considerations. This view underlies the Reference Case and High Price Case paths presented in these forecasts (Figure 4 and Table 13). The other significant view is that prices in real terms are likely to remain relatively constant, following the long-term historical trend of price stability when there have not been substantial political or other factors that constrain supply. This view is reflected in the Low Price Case.

Three alternative paths for world oil prices are presented to evaluate the impacts of different world oil prices on the international oil market. The three price paths result from three different sets of assumptions
Table 13. World Oil Prices, 1970-2010 (1993 Dollars per Barrel)

\begin{tabular}{|c|c|c|c|c|}
\hline \multirow{2}{*}{ History } & \multirow{2}{*}{ Year } & \multirow[t]{2}{*}{ Reference Case } & \multicolumn{2}{|c|}{ Sensitivity Range } \\
\hline & & & & \\
\hline 1970 & $\ldots \ldots$ & 10.30 & - & - \\
\hline 1971 & $\ldots \ldots \ldots$ & 10.40 & - & - \\
\hline 1972 & $\ldots \ldots \ldots$ & 10.10 & - & - \\
\hline 1973 & $\ldots \ldots \ldots$ & 12.00 & - & - \\
\hline 1974 & $\ldots \ldots \ldots$ & 33.80 & - & - \\
\hline 1975 & & 34.30 & - & - \\
\hline 1976 & $\ldots \ldots \ldots$ & 31.20 & - & - \\
\hline 1977 & $\ldots \ldots \ldots$ & 31.50 & - & - \\
\hline 1978 & $\ldots \ldots \ldots$ & 29.30 & - & - \\
\hline 1979 & $\ldots \ldots \ldots$ & 41.10 & - & - \\
\hline 1980 & $\ldots \ldots \ldots$ & 58.70 & - & - \\
\hline 1981 & $\ldots \ldots \ldots$ & 58.30 & - & - \\
\hline 1982 & $\ldots \ldots \ldots$ & 49.70 & - & - \\
\hline 1983 & $\ldots \ldots \ldots$ & 41.70 & - & - \\
\hline 1984 & $\ldots \ldots \ldots$ & 39.40 & - & - \\
\hline 1985 & $\ldots \ldots \ldots$ & 35.50 & - & - \\
\hline 1986 & $\ldots \ldots \ldots$ & 19.90 & - & - \\
\hline 1987 & $\ldots \ldots \ldots$ & 22.50 & - & - \\
\hline 1988 & $\ldots \ldots \ldots$ & 17.40 & - & - \\
\hline 1989 & $\ldots \ldots \ldots$ & 20.70 & - & - \\
\hline 1990 & $\ldots \ldots \ldots$ & 23.90 & - & - \\
\hline 1991 & $\ldots \ldots \ldots$ & 19.70 & - & - \\
\hline 1992 & $\ldots \ldots \ldots$ & 18.70 & - & - \\
\hline 1993 & $\ldots \ldots \ldots$ & 16.12 & - & - \\
\hline 1994 & $\ldots \ldots \ldots$ & 14.90 & - & - \\
\hline Projecti & tions & & & \\
\hline 1995 & $\ldots \ldots \ldots$ & 16.41 & 14.19 & 17.27 \\
\hline 1996 & $\ldots \ldots \ldots$ & 16.90 & 13.45 & 18.49 \\
\hline 1997 & $\ldots \ldots \ldots$ & 17.45 & 13.38 & 19.38 \\
\hline 1998 & $\ldots \ldots \ldots$ & 18.00 & 13.39 & 19.81 \\
\hline 1999 & $\ldots \ldots \ldots$ & 18.53 & 13.49 & 20.44 \\
\hline 2000 & $\ldots \ldots \ldots$ & 19.13 & 13.52 & 21.15 \\
\hline 2001 & $\ldots \ldots \ldots$ & 19.65 & 13.61 & 21.85 \\
\hline 2002 & $\ldots \ldots \ldots$ & 20.16 & 13.66 & 22.60 \\
\hline 2003 & $\ldots \ldots \ldots$ & 20.63 & 13.81 & 23.31 \\
\hline 2004 & $\ldots \ldots \ldots$ & 21.08 & 14.00 & 23.95 \\
\hline 2005 & $\ldots \ldots \ldots$ & 21.50 & 14.25 & 24.55 \\
\hline 2006 & $\ldots \ldots \ldots$ & 21.98 & 14.41 & 25.25 \\
\hline 2007 & $\ldots \ldots \ldots$ & 22.44 & 14.53 & 26.01 \\
\hline 2008 & $\ldots \ldots$ & 22.94 & 14.58 & 26.95 \\
\hline 2009 & $\cdots \cdots \cdots$ & 23.50 & 14.60 & 28.02 \\
\hline 2010 & & 24.12 & 14.65 & 28.99 \\
\hline
\end{tabular}

Sources: History: 1970-1972: Energy Information Administration (EIA), Annual Energy Review 1993, DOE/ EIA-0384(93), Table 5.20. 1973-1992: EIA, Monthly Energy Review, DOE/EIA-0035(94/12), Table 9.1. Projections: EIA, Annual Energy Outlook 1995, National Energy Modeling System runs AEO95B.D1103942, LWOP95.D1103941, and HWOP95.D1103942. 
about OPEC production rates (Figure 30 and Table 14) and about net exports (production less consumption) of oil from China and EE/FSU producers. The Low Price Case uses optimistic production rates from OPEC and the FSU, coupled with a pessimistic economic growth outlook for China and EE/FSU. The High Price Case uses pessimistic production rates for OPEC, China, and EE/FSU and an optimistic economic growth outlook for China and EE/FSU. These are the only assumptions made in generating the three price paths. Non-OPEC production and oil consumption vary across the three cases as a result of the different prices, but the changes are a consequence of the different prices and are not part of the assumptions made to generate the three price cases.

Figure 30. OPEC Oil Production, 1970-2010

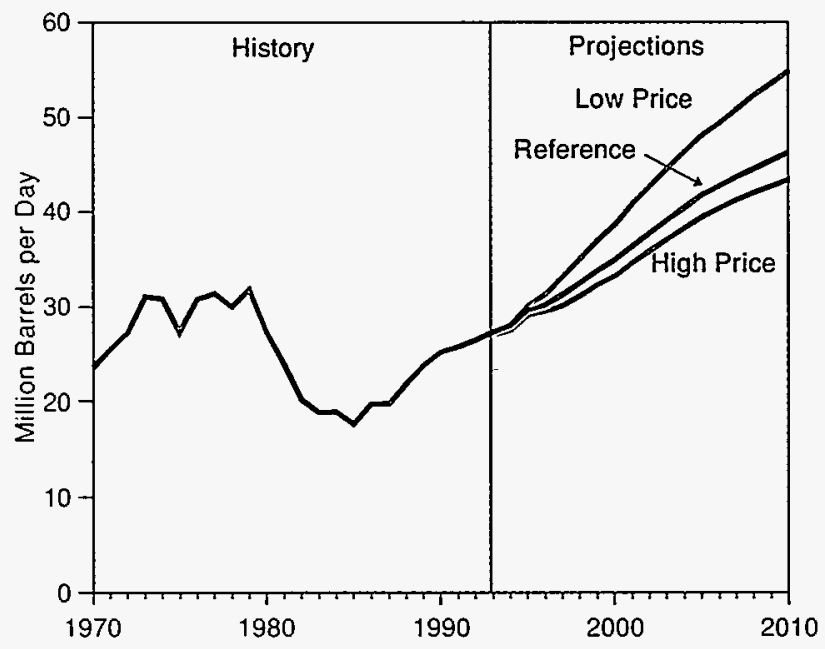

Sources: History: 1970-1979: Energy Information Administration (E|A), Office of Energy Markets and End Use, International Statistics Database. 1980-1992: EIA, International Energy Annual 1992, DOE/ EIA-0219(92) (Washington, DC, January 1994). Projections: EIA, National Energy Modeling System, International Energy Module (1995).

\section{Production Assumptions for World Oil Price Cases}

OPEC oil production is expected to grow significantly in the future, and all three IEO95 price cases assume that Persian Gulf producers will substantially expand their production (Table 14). In the Reference Case, OPEC production in 2010 is assumed to be 46.2 million barrels per day, approaching twice its 1990 level. The assumed OPEC production levels in 2010 are about 3 million barrels per day lower in the High Price Case (43.5 million barrels per day) and about 9 million
Table 14. OPEC Oil Production, 1990-2010 (Million Barrels per Day)

\begin{tabular}{c|c|cc}
\hline \multicolumn{1}{c|}{ Year } & \multicolumn{2}{c}{ Reference Case } & \multicolumn{2}{c}{ Sensitivity Range } \\
\hline History & & & \\
$\quad 1990 \ldots \ldots \ldots$ & 25.1 & - & - \\
Projections & & & \\
$1995 \ldots \ldots \ldots$ & 29.5 & 29.3 & 30.3 \\
$2000 \ldots \ldots \ldots$ & 34.8 & 33.4 & 38.9 \\
$2005 \ldots \ldots \ldots$ & 41.7 & 39.7 & 48.3 \\
$2010 \ldots \ldots \ldots$ & 46.2 & 43.5 & 55.0 \\
\hline
\end{tabular}

Note: Includes the production of crude oil, natural gas plant liquids, refinery gain, and other liquid fuels.

Sources: History: Energy Information Administration (EIA), International Petroleum Statistics Report, DOE/EIA0520(92/08) (Washington, DC, August 1992), Table 1.4. Projections: EIA, National Energy Modeling System, International Energy Module (1995).

barrels per day higher in the Low Price Case (55.0 million barrels per day). The Low Price Case assumes that OPEC production will be near the maximum feasible, as a result of competition among producers for market share and aggressive development to bring additional reserves into production. The High Price Case assumes lower production levels, which could be brought about by a combination of slower development of production capabilities and production further below capacity than is assumed in the Reference Case. The variations in non-OPEC production between the High and Low Price Cases (Table 15) result from the responses of non-OPEC producers to the different price levels, as well as variations in such assumptions as the number of exploration wells, finding rates, reserve-to-production ratios, and advances in extraction technology. ${ }^{4}$

\section{The Case for Rising World Oil Prices}

The Gulf crisis gave an impetus to production capacity expansion plans in most OPEC countries. In the aftermath of the Persian Gulf War, most OPEC observers expected capacity to expand by at least 10 million barrels per day by 2000. However, the persistence of lower prices in the early 1990s has somewhat tempered the optimistic capacity expansion outlook. OPEC argues that low prices result in insufficient capital for investment in production capacity expansion. In addition, the international oil companies whose investment OPEC had hoped to attract are deferring such investment decisions until

\footnotetext{
${ }^{4}$ Production figures and consumption estimates for the Low and High Price Cases presented here, for countries other than the United States, differ slightly from those published in the AEO95, which shares the same oil price paths. The revised production and consumption estimates reflect data and analyses that were not available at the time work on the AEO95 was completed.
} 
Table 15. Non-OPEC Oil Production, 1990-2010

\begin{tabular}{l|c|cc}
\multicolumn{4}{c}{ (Million Barrels per Day) } \\
\hline \multicolumn{1}{c|}{ Year } & Reference Case & Sensitivity Range \\
\hline History & & & \\
$1990 \ldots \ldots \ldots$ & 41.6 & - & - \\
Projections & & & \\
$1995 \ldots \ldots \ldots$ & 40.4 & 40.2 & 40.5 \\
$2000 \ldots \ldots \ldots$ & 41.5 & 40.2 & 42.1 \\
$2005 \ldots \ldots \ldots$ & 41.2 & 39.4 & 42.2 \\
$2010 \ldots \ldots \ldots$ & 42.2 & 39.5 & 43.6 \\
\hline
\end{tabular}

Note: Includes the production of crude oil, natural gas plant liquids, refinery gain, and other liquid fuels.

Sources: History: Energy Information Administration (EIA), International Petroleum Statistics Report, DOE/EIA0520(92/08) (Washington, DC, August 1992), Table 1.4. Projections: EIA, National Energy Modeling System, International Energy Module (1995).

their own revenue situations improve. Historically, in periods of low prices (the 1960s and late 1980s), OPEC countries have tended to make investments in upstream operations to expand their reserves. In periods of higher prices, investments have been made in downstream operations-refining and production capacity expansion-as these investments are more expensive.

Most oil market analysts agree that OPEC will have to continue capacity expansion after 2000 to meet growing world oil demand. However, many estimates have OPEC capacity peaking and stabilizing at a level of about 45 million barrels per day. Two reasons are given for this stabilization. First, part of all capacity additions in the post-2000 time frame will be used to offset the production declines from old fields (some of them "super-giant" complexes in the Middle East). Second, OPEC producers are not inclined to develop fields that contain heavy crude oils (which make up a substantial part of total reserves). Whereas there is considerable potential to expand capacity in such fields (particularly in Saudi Arabia and Venezuela), OPEC argues that worldwide downstream refining capacity is not sophisticated enough at present to upgrade these heavier crude oils into the lighter products.

With current worldwide refining capacity running at about 73 million barrels per day, significant capacity expansion would have to take place over the next 15 years to satisfy the 89 million barrels per day of world oil demand implied by the Reference Case forecast for
2010 (Table A3). Not only would expansion be needed in crude oil distillation capacity, but investment in substantial downstream capacity would also be required in order to upgrade heavier crude oils into the lighter products. It is not clear whether sufficient investment capital would be available, especially for expensive downstream capacity, if it were perceived that oil prices would remain at their current low levels.

Since 1990, worldwide demand for oil has been increasing by between 1.5 and 2.0 million barrels per day per year, with particularly strong growth in the developing countries of the Pacific Rim. The liberalization of economic policies in India, China, and ultimately Russia would also have an upward impact on demand. This demand outlook, coupled with global inventories that are currently at their lowest levels in 5 years and no substantial excess OPEC production capacity, could signal an end to declining or level world oil prices.

\section{The Case for Low World Oil Prices}

The lower prices in the Low Price Case reflect recent experience as well as long-term historic trends in prices prior to the increases of the 1970s and 1980s. Analysts predicting the continuation of relatively constant prices point to continuing advances in exploration and extraction technology that will allow the development of previously uneconomical oil deposits both within and outside OPEC. They also note the growing competitive potential of natural gas use, especially in power generation applications.

There are several factors that could lead to expansion of oil production capacity, resulting in a worldwide production capacity that could readily meet increased demand for oil at stable prices. Oil exports from the FSU could resume as the FSU countries' economies recover, giving rise to higher productivity in energy production and expanded output from known, but not yet developed, reserves. A return of Iraq to the world market could readily result in excess production capacity in OPEC, leading to intense squabbling among OPEC members as they compete to maintain market shares.

Lower world oil prices would also result from reduced growth in energy demand. An example of potential factors that could lead to lower growth in demand would be increased energy conservation efforts, accelerated both by legislation and by the public's strong support of environmental initiatives. 


\section{Comparison With Other Price Forecasts}

Comparisons with other price forecasts are shown in Table 16. The range between the IEO95 Low Price and High Price forecasts spans the range of other published forecasts. Most of the forecasts published to date, with the exception of PEL, are in the "prices will rise" camp. The IEA's 1994 projections indicate a strong price recovery by 2005 , with prices remaining flat thereafter. In their view, a price rise will be needed to encourage rapid growth in production levels. Discussions with other oil market analysts, however, suggest that there is also support among knowledgeable analysts for relatively constant prices. ${ }^{5}$ The major source of differences in perceptions regarding future price trends relates to expectations about the potential for low-cost sources of oil production to be brought to market.

\section{References}

1. Energy Information Administration. Short-Term Energy Outlook, First Quarter 1995. DOE/EIA-0202(95/ 1Q). Washington, DC, February 1995.

2. International Petroleum Encyclopedia 1994, Vol. 27. Tulsa, OK: PennWell Publishing, 1994.

3. "DESTINY" International Energy Forecast Software. Dallas, TX: Petroconsultants, 1995.

Table 16. Comparison of World Oil Price Projections, 2000-2010

(1993 Dollars per Barrel)

\begin{tabular}{|c|c|c|c|c|c|c|c|c|c|c|}
\hline \multirow[b]{2}{*}{ Year } & \multicolumn{3}{|c|}{ IEO95 } & \multirow[b]{2}{*}{ IEA } & \multirow[b]{2}{*}{ PEL } & \multirow[b]{2}{*}{ DRI } & \multirow[b]{2}{*}{ WEFA } & \multirow[b]{2}{*}{ GRI } & \multirow[b]{2}{*}{ NRC } & \multirow[b]{2}{*}{ CEC } \\
\hline & $\begin{array}{c}\text { Reference } \\
\text { Case }\end{array}$ & $\begin{array}{r}\text { Sen: } \\
R=\end{array}$ & $\begin{array}{l}\text { tivity } \\
\text { ge }\end{array}$ & & & & & & & \\
\hline 2000 & 19.13 & 13.52 & 21.15 & 23.00 & 14.99 & 19.98 & 18.75 & 18.58 & 20.00 & 21.06 \\
\hline 2005 & 21.50 & 14.25 & 24.55 & 28.00 & 14.15 & 24.67 & 20.36 & - & 22.00 & 23.21 \\
\hline 2010 & 24.12 & 14.65 & 28.99 & 28.00 & 14.97 & 28.07 & 21.36 & 20.54 & 22.00 & 25.56 \\
\hline
\end{tabular}

Sources: IEO95: Energy Information Administration, Annual Energy Outlook 1995, DOE/EIA-0383(95) (Washington, DC, January 1995), Tables A1 and C1. DRI: DRI/McGraw-Hill, Energy Review (Spring-Summer 1994). WEFA: The WEFA Group, U.S. Long-Term Economic Outlook (Third Quarter 1994). IEA: International Energy Agency, World Energy Outlook 1995 (Paris, France, 1995), Capacity Constraints Case. GRI: Gas Research Institute, Baseline Projection Data Book (1994 Edition). PEL: Petroleum Economics Limited, World-Long Term Oil and Energy Outlook (November 1994). NRC: Natural Resources Canada, Canada's Energy Outlook 1992-2020: Update 1994 (October 1994). CEC: California Energy Commission, "Delphi VII" (1993).

${ }^{5}$ Representatives from Aramco, for example, presented this view at a meeting with EIA in January 1995. 


\section{Concerns about energy security and environmental protection make natural gas an attractive fuel in many regions. Abundant reserves are available to meet growing demand worldwide.}

Two primary factors have made, and continue to make, natural gas an extremely important fuel. First is energy security. The abundance of natural gas reserves throughout the world indicates not only that there will be a plentiful supply of gas for many years, but also that supplies will not rely on a limited number of major producers. Environmental concerns are the second factor. Natural gas is increasingly viewed as an environmentally friendly fuel. Concerns about global warming and local air pollution are causing many countries to encourage increased use of natural gas, which burns more cleanly than either oil or coal. Many of the "ultraclean" renewable fuels have drawbacks. For example, the dams built for hydroelectric power plants displace people, alter ecologies, and impose other environmental costs that are now recognized to be significant in many areas. As a result, the already limited range of opportunity for hydropower capacity expansion is further reduced. Solar, geothermal, and other renewable sources of energy are being developed, but it is improbable that they will have a significant impact on the supply of energy by 2010, given current capital requirements per unit of energy output. Therefore, natural gas is likely to have a competitive advantage in many areas of the world to meet increasing energy requirements or to displace fuels that have environmental disadvantages.

Worldwide consumption of natural gas is projected to increase by 47 percent between 1990 and 2010 (Figure 31 ), while the projected increase in overall energy consumption is only 36 percent for the same time period (Figure 32). On a regional basis, non-OECD Asia shows the largest increase in demand for natural gasabout 140 percent, from 2.9 trillion cubic feet to 7 trillion cubic feet-over the 20 -year period. The rapidly increasing demand in non-OECD Asia is driven primarily by the region's strong economic growth. Still, non-OECD Asia will account for slightly under 7 percent of total world gas consumption in 2010. In contrast, the projected increase for OECD North America, which should account for 29 trillion cubic feet of consumption (27 percent of total world consumption) in 2010, is about 32 percent for the 1990 to 2010 period.
Figure 31. World Consumption of Natural Gas, 1970-2010

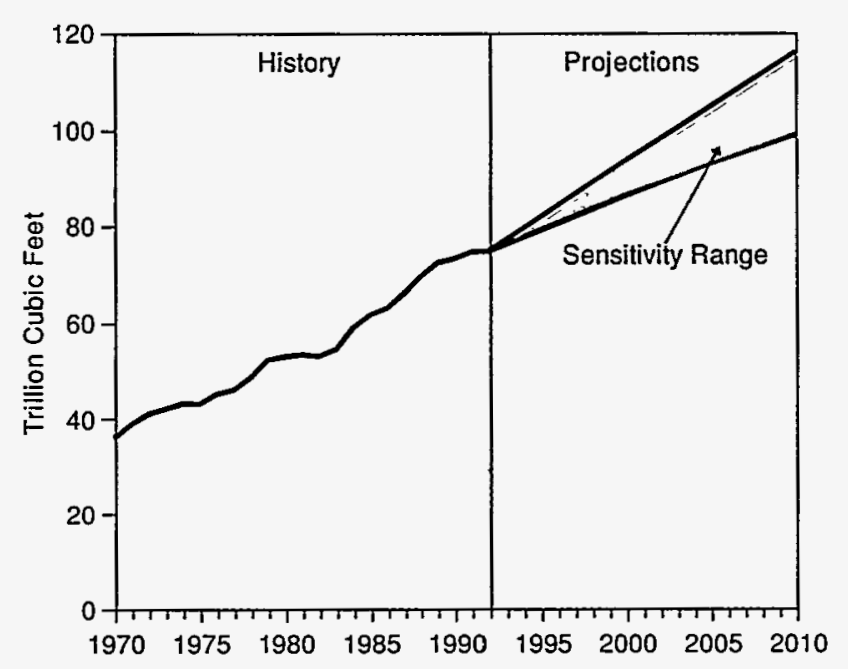

Sources: History: 1970-1979: Energy Information Administration (EIA), Office of Energy Markets and End Use, International Statistics Database. 1980-1992: EIA, International Energy Annual 1992, DOE/ EIA-0219(92) (Washington, DC, January 1994). Projections: EIA, World Energy Projection System (1995).

Both the OECD Europe and OECD Pacific regions are expected to experience substantial growth in gas use during the 20-year period, about 94 percent and 67 percent, respectively, putting total OECD consumption at 53.5 trillion cubic feet in 2010. The growth in demand in these two OECD regions is a result of the relatively low price of natural gas, as well as environmental concerns that favor the use of this clean-burning fuel. In the EE/FSU region, which accounted for the largest consumption of any region at 28.1 trillion cubic feet in 1990 , natural gas use is expected to increase by 24 percent by 2010. Both the Middle East and Central and South America regions should show increases of about 67 percent. Africa's consumption of natural gas is projected to increase to 2.2 trillion cubic feet (an increase of 57 percent) by 2010 (Figure 33). North America and the EE/FSU together accounted for 69 percent (50.1 trillion cubic feet) of world gas consumption in 1990 (Table 17). By 2010 their combined share should fall to 
Figure 32. World Consumption of Natural Gas Relative to All Other Energy Sources, 1970-2010

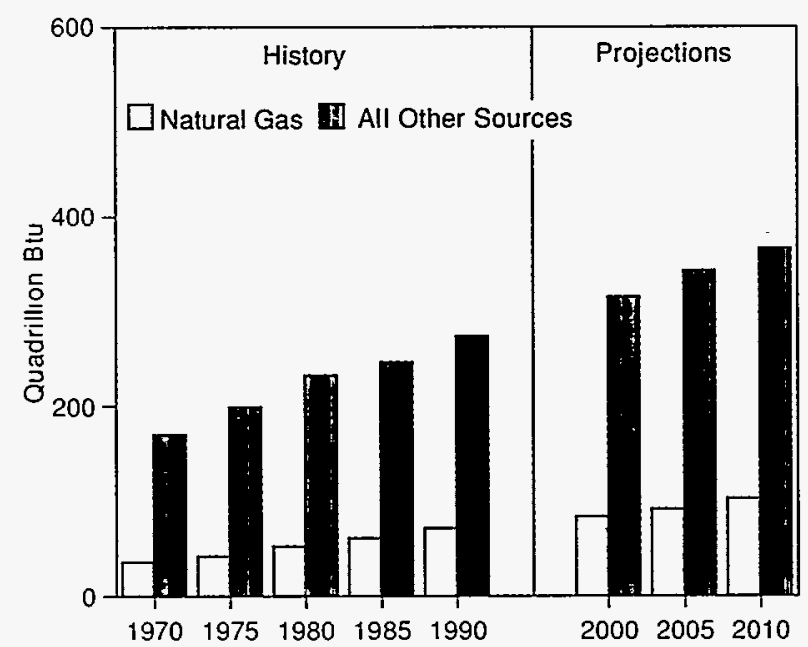

Sources: History: 1970-1979: Energy Information Administration (EIA), Office of Energy Markets and End Use, International Statistics Database. 1980-1992: EIA, International Energy Annual 1992, DOE/EIA-0219(92) (Washington, DC, January 1994). Projections: EIA. World Energy Projection System (1995).

about 60 percent (63.9 trillion cubic feet), as other regions, most notably OECD Europe and non-OECD Asia, increasingly rely on natural gas to satisfy energy needs.

Figure 33. Natural Gas Consumption by Region, $1970-2010$

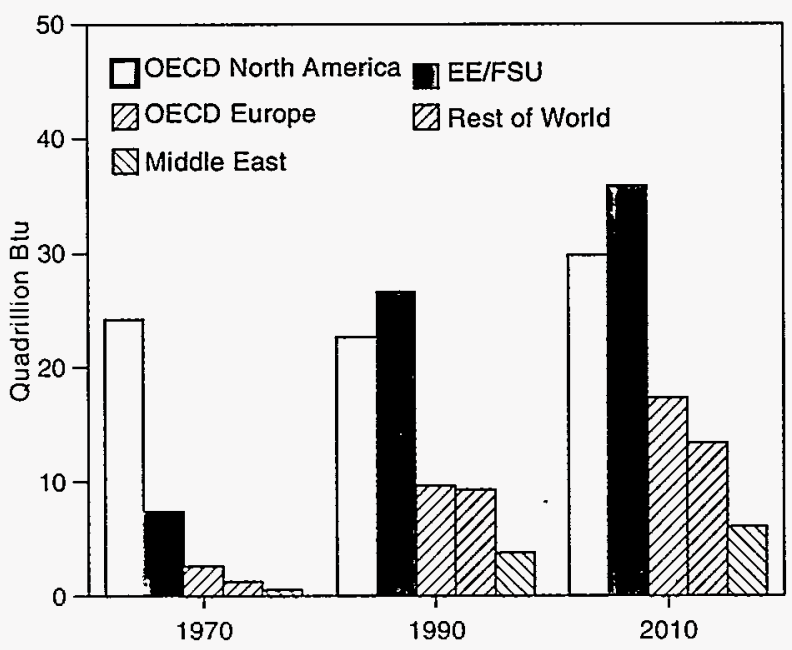

Sources: History: 1970-1979: Energy Information Administration (EIA), Office of Energy Markets and End Use, International Statistics Database. 1980-1992: EIA, International Energy Annual 1992, DOE/EIA-0219(92) (Washington, DC, January 1994). Projections: ElA, World Energy Projection System (1995).
Some recent events in the worldwide natural gas industry are likely to figure prominently in the future of natural gas: numerous (and frequently ambitious) pipeline projects, and a push in many regions to increase the use of natural gas for electricity generation.

Major pipeline projects are popping up throughout the world. The countries of South America are planning many such projects to take advantage of an indigenous resource that has been underutilized in the past. In Africa, Algeria is strengthening its European export markets as other African countries begin to develop their own gas industries. Europe continues to diversify its gas supply base through pipeline projects with various suppliers. Countries in Southeast Asia are considering extremely ambitious plans to link most of the producers to consumers via a massive pipeline system.

Many of the regions that are expanding natural gas consumption are planning to use increasing amounts of gas in the power generation sector. Technological advances in gas-fired generation and the environmental advantages of natural gas make it an attractive fuel for power generation, especially in China and the countries of Eastern Europe, which currently rely heavily on coal.

Table 17. Shares of World Natural Gas Consumption by Region, 1990, 2000, and 2010

(Percent of Total)

\begin{tabular}{|c|c|c|c|}
\hline \multirow[b]{2}{*}{ Region } & \multirow{2}{*}{$\frac{\text { History }}{1990}$} & \multicolumn{2}{|c|}{ Projections } \\
\hline & & 2000 & 2010 \\
\hline OECD North America $\ldots .$. & 30.2 & 28.9 & 27.0 \\
\hline OECD Europe & 14.1 & 17.2 & 18.6 \\
\hline OECD Pacific $\ldots \ldots$ & 3.6 & 4.3 & 4.2 \\
\hline EE/FSU $\ldots \ldots$ & 38.4 & 34.2 & 32.6 \\
\hline Non-OECD Asia & 4.0 & 5.1 & 6.5 \\
\hline Middle East & 4.9 & 5.7 & 5.6 \\
\hline Africa & 1.9 & 2.0 & 2.1 \\
\hline Central and South America .. & 2.9 & 2.6 & 3.3 \\
\hline
\end{tabular}

Notes: OECD = Organization for Economic Cooperation and Development. EE/FSU = Eastern Europe/Former Soviet Union. Sum of shares may not equal 100 percent due to independent rounding.

Sources: History: Derived from Energy Information Administration (EIA), International Energy Annual 1992, DOE/EIA-0219(92) (Washington, DC, January 1994), Table 9. Projections: EIA, World Energy Projection System (1995). 


\section{Reserves}

Proven world gas reserves as of January 1, 1995, are estimated at approximately 4,980 trillion cubic feet, a decrease of 36 trillion cubic feet from a year earlier. ${ }^{6}$ The FSU still accounts for nearly 40 percent of this total (Table 18). On a regional basis, EE/FSU and the Middle East together account for slightly over 70 percent of world reserves. The remainder is fairly evenly distributed among other world regions-OECD North America, Central and South America, OECD Europe, Africa, and non-OECD Asia. The exception is the OECD Pacific region, which has only a small amount of reserves (Figure 34).

Table 18. World Natural Gas Proven Reserves by Country as of January 1, 1995

\begin{tabular}{|c|c|c|}
\hline Country & $\begin{array}{c}\text { Reserves } \\
\text { (Trillion } \\
\text { Cubic Feet) }\end{array}$ & $\begin{array}{c}\text { Percent of } \\
\text { World } \\
\text { Total }\end{array}$ \\
\hline World Total . . . . . . . . . . & $4,980.3$ & 100.0 \\
\hline Top 20 Countries $\ldots . \ldots$ & $4,595.8$ & 92.3 \\
\hline Former Soviet Union . . . . . . & $1,977.0$ & 39.7 \\
\hline $\operatorname{Iran} \ldots \ldots \ldots \ldots \ldots$ & 741.6 & 14.9 \\
\hline 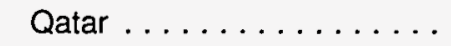 & 250.0 & 5.0 \\
\hline Abu Dhabi $\ldots \ldots \ldots \ldots$ & 188.4 & 3.8 \\
\hline Saudi Arabia $\ldots \ldots \ldots \ldots$ & 185.4 & 3.7 \\
\hline United States $\ldots \ldots \ldots \ldots$ & 162.4 & 3.3 \\
\hline Venezuela ........... & 130.4 & 2.6 \\
\hline Algeria . . . . . . . . . . & 128.0 & 2.6 \\
\hline Nigeria . . . . . . . . . . & 120.0 & 2.4 \\
\hline Iraq $\ldots \ldots \ldots \ldots$ & 109.5 & 2.2 \\
\hline Canada $\ldots \ldots \ldots \ldots$ & 79.2 & 1.6 \\
\hline Norway $\ldots . . \ldots \ldots \ldots$ & 70.9 & 1.4 \\
\hline Mexico . . . . . . . . . . . & 69.7 & 1.4 \\
\hline Malaysia ............ & 68.0 & 1.4 \\
\hline Netherlands $\ldots \ldots \ldots \ldots$ & 66.2 & 1.3 \\
\hline Indonesia ........... & 64.4 & 1.3 \\
\hline China $\ldots \ldots \ldots \ldots \ldots$ & 59.0 & 1.2 \\
\hline Kuwait $\ldots \ldots \ldots \ldots$ & 52.4 & 1.1 \\
\hline Libya . . . . . . . . . . . & 45.8 & 0.9 \\
\hline Pakistan . . . . . . . . . . & 27.5 & 0.6 \\
\hline Rest of World . . . . . . . & 384.5 & 7.7 \\
\hline
\end{tabular}

Note: The sum of the shares for the top 20 countries may not equal their total share due to independent rounding.

Source: "Worldwide Look at Reserves and Production," Oil and Gas Journal, Vol. 92, No. 52 (December 26, 1994), pp. 42-43.
Figure 34. World Natural Gas Proven Reserves by Region, as of January 1, 1995

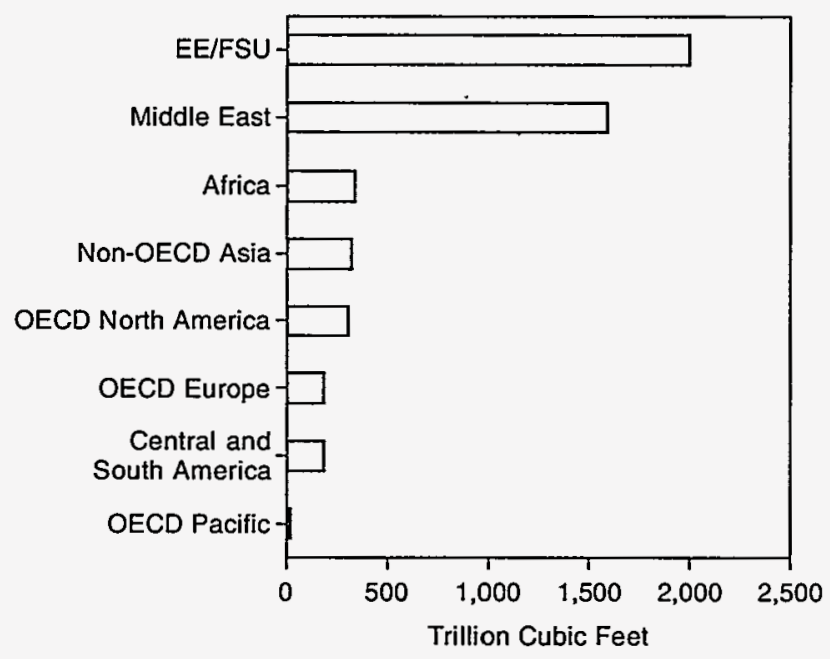

Source: "Worldwide Look at Reserves and Production," Oil and Gas Journal, Vol. 92, No. 52 (December 26, 1994), pp. 42-43.

Over the past 20 years, estimated worldwide reserves of natural gas have increased by 96 percent. Since 1975, estimates of reserves in OECD nations have fluctuated somewhat, but they have basically remained the same (Figure 35 and Table 19). Estimates for the non-OECD

Figure 35. OECD and Non-OECD Natural Gas Proven Reserves, 1972-1995

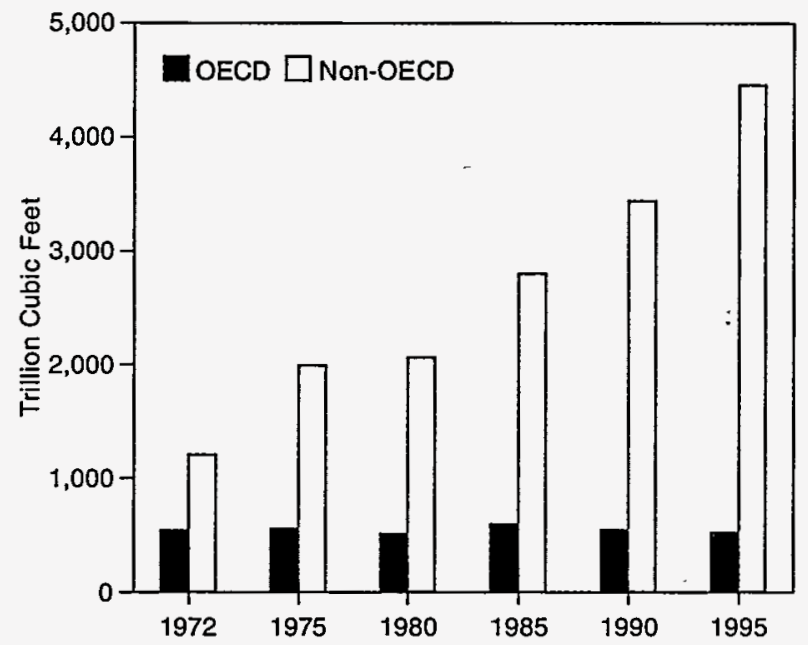

Sources: 1972-1990: International Petroleum Encyclopedia: Worldwide Oil and Gas at a Glance (Tulsa, OK: PennWell Publishing Co.), various issues. 1995: "Worldwide Look at Reserves and Production," Oil and Gas Journal, Vol. 92, No. 52 (December 26, 1994), pp. 42-43.

${ }^{6}$ Proven reserves are the estimated quantities that analysis of geological and engineering data demonstrate with reasonable certainty to be recoverable in future years from known reservoirs under existing economic and operating conditions. 
Table 19. Historical Estimates of Natural Gas Proven Reserves by Region, 1975-1995 (Trillion Cubic Feet)

\begin{tabular}{|c|c|c|c|c|c|}
\hline Region & 1975 & 1980 & 1985 & 1990 & 1995 \\
\hline$\ldots \ldots \ldots \ldots$ & 554 & 510 & 598 & 547 & 526 \\
\hline 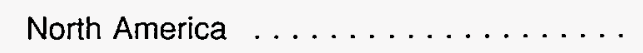 & 309 & 338 & 367 & 333 & 311 \\
\hline Europe $\ldots \ldots \ldots \ldots \ldots \ldots \ldots$ & 201 & 134 & 207 & 192 & 191 \\
\hline Pacific ........ & 45 & 38 & 24 & 23 & 24 \\
\hline Non-OECD . . . & 1,991 & 2,063 & 2,804 & 3,442 & 4,454 \\
\hline EE/FSU $\ldots \ldots$ & 823 & 911 & 1,467 & 1,528 & 2,002 \\
\hline Non-OECD Asia & 96 & 116 & 173 & 261 & 327 \\
\hline Middle East $\ldots$ & 671 & 740 & 869 & 1,226 & 1,594 \\
\hline Africa $\ldots \ldots \ldots \ldots \ldots \ldots \ldots$ & 315 & 210 & 187 & 267 & 342 \\
\hline Central and South America ......... & 85 & 86 & 108 & 160 & 189 \\
\hline Total World & 2,545 & 2,573 & 3,402 & 3,989 & 4,980 \\
\hline
\end{tabular}

Notes: OECD = Organization for Economic Cooperation and Development. EE/FSU = Eastern Europe/Former Soviet Union. Sources: 1975-1990: International Petroleum Encyclopedia: Worldwide Oil and Gas at a Glance (Tulsa, OK: PennWell Publishing Co.), various issues. 1995: "Worldwide Look at Reserves and Production," Oil and Gas Journal, Vol. 92 , No. 52 (December 26, 1994), pp. 42-43.

region have increased by nearly 125 percent, with dramatic increases in reserve estimates for the EE/FSU and Middle East regions.

In North America, potential access to an expanded resource base is one advantage of free trade. The United States has a relatively large economically recoverable resource base, ${ }^{7}$ estimated at 852 trillion cubic feet using 1990 technology [1, p. 40], including 317 trillion cubic feet of unconventional resources (gas from tight sand formations, Devonian shale, and coalbed methane). Canadian undiscovered marketable gas resources are estimated at 130 trillion cubic feet, including 20 trillion cubic feet from coalbed methane [2, p. 6-6]. Mexico also has large undiscovered and unexploited gas resources from conventional sources, estimated at 180 trillion cubic feet [3, p. 180]. But, unlike Canada, Mexico has not developed the infrastructure needed to get its gas resources from the field to the market.

\section{Natural Gas Transportation}

As the name implies, natural gas is extracted in a gaseous state, as opposed to a liquid or solid state like oil and coal. Transportation of natural gas is therefore relatively difficult, since the gas must be kept in a completely closed unit for transportation. Pipelines are the most common means of moving gas. But because of geographic situations, not all gas suppliers can be linked with consumers via pipeline. In such situations, the gas must be converted to a liquid state, known as liquefied natural gas (LNG), and shipped to its destination.

Once natural gas has been converted at low temperature to a liquid state, it can be loaded onto specially designed, refrigerated ships and delivered to ports anywhere in the world that are equipped with the necessary receiving facilities, then regasified and distributed further by pipeline as required. The drawback to LNG is that the conversion process, the ships themselves, the handling, and the specialized facilities needed add considerably to the fuel's delivered cost, reducing its economic attractiveness.

Most of the world's LNG trade occurs in Southeast Asia. There is also a substantial amount of LNG activity in and around Europe. Both North America and Europe have well-developed pipeline systems, and a large amount of international pipeline trade occurs in those areas. Overall, about three-quarters of worldwide gas trade is by pipeline and one-quarter by LNG. This split could tilt more in favor of pipelines if some of the major pipeline projects discussed in this chapter are completed as planned.

\footnotetext{
${ }^{7}$ Economically recoverable resources are those volumes considered to be of sufficient size and quality for their production to be commercially profitable by current conventional technologies, under specified economic assumptions. They include proven reserves, inferred reserves, and undiscovered and other unproven reserves. These resources may be recoverable by techniques considered either conventional or unconventional.
} 


\section{Regional Activity}

\section{North America}

Recent natural gas trade in North America reflects the increasingly integrated and competitive nature of the gas market on this continent. The North American natural gas industry is moving toward a much less regulated operating environment, and that trend is reflected in the natural gas market outlook. The North American Free Trade Agreement (NAFTA) is expected to enhance the economic efficiency of the North American markets; however, given Mexico's inclusion of reservations and exceptions to the energy-related provisions of NAFTA, the uncertainty surrounding trade with Mexico has not been reduced significantly.

\section{United States}

Natural gas demand in the United States is expected to increase over the next two decades. U.S. consumption of natural gas is projected to reach 22.1 trillion cubic feet in 2000, increasing at an average annual rate of 1.1 percent, to 24.6 trillion cubic feet by 2010 . The projected increase results, in part, from technology developments that increase the usefulness of natural gas for power generation, and also from environmental initiatives, such as the 1990 Clean Air Act Amendments, which encourage the move toward cleaner burning fuels. To meet the expected increase, gas supplies from all sources (pipeline imports, LNG imports, and domestic production) are expected to rise.

Total net imports accounted for 11 percent of U.S. consumption of natural gas in 1993; in 2010, they are expected to provide 15 percent of the total U.S. supply. Natural gas pipeline imports come from two sources, Canada and Mexico. Imports from Canada are expected to increase from 2.2 trillion cubic feet in 1993 to roughly 3 trillion cubic feet in 2010. Currently, the level of imports from Canada is constrained by pipeline capacity across the border, but with the completion of proposed expansion projects, an increase in the current level can be achieved. Mexico has the potential to be another significant source of supply, although large investments in gas transportation and distribution infrastructures will be required. Low oil prices have resulted in reduced funding for gas projects, making the timing of future import flows uncertain.

LNG imports also are expected to increase over the next two decades. LNG remains a relatively small portion of national supply, accounting for only 3 percent of consumption by 2010 , although it is a significant factor in the outlook for certain regional markets. Of the four existing regasification plants in the United States, only those at Everett, Massachusetts, and Lake Charles, Louisiana, are currently in operation. The regasification facility at Cove Point, Maryland, with a sustainable vaporization capacity of 365 billion cubic feet per year, is the largest in the United States. It is projected to reopen by 2007. With market prices for gas remaining relatively low throughout the forecast, the plant at Elba Island, Georgia, is not expected to reopen within the projection horizon.

In addition to the growing market share of gas imports, domestic gas production is expected to increase at an average annual rate of 0.8 percent between 1993 and 2010. The majority of the domestic supply is projected to come from onshore nonassociated gas from conventional sources, increasing from 8.7 trillion cubic feet in 1993 to 11.1 trillion cubic feet in 2010. Production from unconventional sources is also expected to increase significantly, from 2.1 trillion cubic feet in 1993 to 3.0 trillion cubic feet in 2010.

\section{Canada}

Canada's natural gas consumption is projected to increase at a rate of 2 percent per year throughout the forecast period, with production growing faster than domestic demand as exports to the United States rise. Canadian domestic gas production is expected to increase from 4.7 trillion cubic feet in 1993 to 5.8 trillion cubic feet in 2010. Prior to 2010, no significant production is expected from the frontier areas or from unconventional sources. Imports from the United States begin at 0.05 trillion cubic feet in 1993 and are expected to rise to 0.24 trillion cubic feet by 2010 .

\section{Mexico}

Consumption of natural gas is also expected to rise in Mexico. Pollution is an increasing concern in Mexico, and natural gas is an attractive alternative to the use of high-sulfur heavy fuel oil for power generation and other industrial applications. Current government policy requires that all domestically produced high-sulfur heavy fuel oil be consumed domestically, and changes to that policy will be needed if natural gas is to penetrate the market in a substantial way.

Although Mexican reserves of natural gas are relatively abundant, the long-term supply from domestic sources is expected to fall short of meeting domestic demand at the going market price for some years to come. Because existing transportation networks are not sufficient to permit the exploitation of Mexico's known reserves, imports from the United States and Canada will continue 
to meet market growth. As the market price for natural gas increases, the Mexican government will most likely increase domestic production. However, increased production requires prior investment in infrastructure development, and the potential for and timing of significant increases in production will depend on the government's ability to make the needed investments.

\section{Central and South America}

The natural gas industry in Central and South America has great potential. With the exception of Venezuela and Argentina, the South American gas infrastructure is underdeveloped. With reserves equivalent to those of North America, Central and South American countries are expected to start exploiting more of their natural gas production potential, aided by current favorable economic trends. Almost all the countries of South America are becoming involved with gas in some way. Bolivia, Argentina, Peru, Venezuela, Trinidad and Tobago, and Colombia are likely to become important gas producers, not only able to satisfy their own domestic needs, but also becoming exporters to countries such as Brazil, Chile, Uruguay, and Paraguay.

Numerous international pipeline projects are either currently underway or scheduled for completion over the next 10 years. The two most notable projects are the Bolivia-Brazil and Argentina-Chile pipelines. The Bolivia-Brazil pipeline is the most ambitious project in South America, with a planned route running from Bolivia to Sao Paulo, Brazil, scheduled for completion by the turn of the century. The completion date appears likely, since most points of negotiation have been resolved, although some remaining financial issues still could delay the project. Construction of an ArgentinaChile pipeline also appears likely, with two rival consortia competing for the project with similar pipeline proposals. Both proposed pipelines terminate in Santiago, Chile.

Other pipeline projects include a Bolivia-Northern Chile pipeline, a Bolivia-Paraguay pipeline, a Peruvian stem of the Bolivia-Brazil pipeline, an Argentina-Brazil pipeline, and a domestic pipeline network in Colombia linking all major cities to a national grid $[4$, p. 10; 5, pp. 5, $22-23 ; 6$, p. 23$]$.

\section{Europe}

The natural gas industry is well established in most of Europe. Current projects are meant either to increase the amount of gas available or to connect the European grid to countries with less established gas systems. Within Europe itself, the two main suppliers are expect- ed to be Norway and the Netherlands, both of which have sizable gas reserves. Just outside Europe there are many current and probable future suppliers, including Russia, Algeria, Nigeria, Iran, Oman, and Qatar. LNG will also be available from more distant regions, such as the Caribbean and Southeast Asia. With so many possible suppliers, it is unlikely that Europe as a whole will experience any substantial and protracted gas supply disruptions.

In Northern Europe, Norway should play an increasingly important role in gas supply during the next decade. Contractual obligations have Norway challenging Russia as the dominant gas supplier to France just after the turn of the century [7, p. 67]. Germany and Belgium will also rely heavily on Norwegian gas, which is expected to cover close to one-third of the total demand in each country [8, p. x]. Norway is also exploring export options in Central and Eastern Europe as countries in that region try to diversify gas suppliers. If the Russian Yamal pipeline project (due for completion in 2010) is successful, Russia will probably once again be the primary gas supplier to many countries in Northern and Eastern Europe.

Two recent pipeline projects, both terminating in Spain, have the potential to play an important role in the future supply of gas to the western part of Europe. The first, which is already complete, links northern Spain to the rest of Europe through a connection to the French grid at Lacq, France. This new link has already been used by Spain to import gas from Norway [9, p. 38]. The second project, the Maghreb-Spain pipeline, is scheduled for completion within the next 2 years. The pipeline will run from Algeria, through Morocco, across the Straits of Gibraltar, and into Spain. Projects to link it to a Portuguese grid are also underway, and Portugal expects to begin importing Algerian gas in 1997 [8, p. ii]. The next step will be to link the Maghreb-Spain pipeline to the French pipeline grid, thereby giving Algeria pipeline access to markets in Northern Europe.

In addition to the existing LNG import facilities in many European countries, new LNG facilities in Greece and Turkey are planned. Gas demand is expected to rise in both countries, and both are looking to strengthen supply options by investing in LNG facilities and pipeline connections [8, p. vi]. Pipeline connections, both those in place and those under construction, link the two countries with Russian and/or Iranian suppliers.

Gas should play an increasingly important role in Eastern Europe as many countries try to shift from coal to gas, especially in the electric power generation sec- 
tor. Russia is likely to remain the primary supplier of natural gas to the region, although other gas-rich countries in and around the region, such as Norway, the Netherlands, Algeria, and Iran, may try to get involved. As demand increases, there could be difficulties caused by financial problems and the current lack of gas infrastructure in the region $[10$, p. 18].

\section{Former Soviet Union}

The former Soviet Union (FSU) continues to experience economic and political instability. Although these difficulties will probably slow growth in natural gas supply for the short term, the industry will almost certainly grow significantly over the long term. Norway will probably be the most important supplier of gas to many countries in Europe over the next decade or two, but beyond this time frame the countries of the FSUprimarily Russia-will likely become the biggest suppliers of gas. The Yamal pipeline project, if successful, will play a major role in Russian gas exports to Europe. Scheduled for completion in 2010, it calls for a 4,000kilometer pipeline that would connect northern Siberia with Western Europe [8, p. xii]. The pipeline would run through Poland and avoid the Ukraine, which has had recent disagreements with Russia over pipeline usage and fees.

Russia is also making plans to take advantage of its gas resources in the Pacific region, especially those around Sakhalin Island. Potential importers of Russian gas include North Korea, South Korea, Japan, and China. Pipelines would connect Russia to South Korea, North Korea, and China, while trade with Japan would be conducted by either undersea pipeline or LNG shipments [11, p. 54]. Additional markets in Southeast Asia will also be accessible if the pan-Asian pipeline project works out (see Asia/Pacific below). Kazakhstan and Turkmenistan also have significant gas reserves, and both could play important roles in future European plans for gas imports [8, p. xiii].

\section{Africa}

In Africa, Algeria has clearly been the leader in natural gas production, exports, and infrastructure. It has the largest gas reserves in Africa, although only by a small margin over Nigeria. The Trans-Mediterranean Pipeline has transported Algerian gas to Italy for many years, and construction is already underway on a twin pipeline that will double export capacity to Italy. A second major pipeline project, also underway, will connect Algeria to Spain, running through Morocco and across the Straits of Gibraltar [8, p. x]. As noted earlier, this pipeline will allow Algeria acçess to gas markets in most of Europe. Algerian LNG facilities have been shipping gas throughout the world for years, and projects are also underway to increase the country's LNG export capacity. With new pipeline and LNG projects already underway, it is likely that Algeria will remain at the forefront of African natural gas activity. Political instability resulting from the conflict between the government and Islamic fundamentalists is the largest threat to a reliable and continuous supply of gas from Algeria.

With the exception of Algeria, most African countries have been slow to take advantage of their natural gas resources. That now appears to be changing in some countries. The Nigerian LNG export project once again appears to be headed in the right direction, with an expected startup date of 1999 [8, p. iv]. With new discoveries in Egypt, gas has recently become that country's most important fossil fuel for domestic consumption. Egypt may eventually be able to begin gas export projects, with Israel, Jordan, Lebanon, and Turkey as potential customers [8, p. iv]. In the southern part of Africa, an area not known for natural gas, plans are being made to build a pipeline from the Pande gas field in Mozambique to near Johannesburg, South Africa. Sponsors expect the project to meet local demand for approximately 20 years $[12, \mathrm{p} .1]$.

\section{Middle East}

The Middle East region is not only well endowed with oil resources, it also has a large portion of the world's natural gas resources. Some of the emerging players in the region are Iran, Oman, Qatar, and Abu Dhabi. Iran, with the world's second largest gas reserves, has the most potential in the region. Iran will have access to markets in Southern and Eastern Europe through a new Balkans pipeline [10, p. 20]. Although Iran has the largest production potential in the region, countries such as Qatar and especially Oman have been more ambitious in their development efforts.

LNG projects in both Qatar and Oman are focused on exporting to Southeast Asia and Europe, with deliveries expected by the end of the century [8, p. iv]. Oman is in the first stages of a project to build an undersea pipeline to India. The primary obstacle for the project is the depth of water, which is four times deeper than any existing undersea pipeline. Recent advances have made this project technologically and financially possible. The completion date is set for 1999. If the project is successful, many similar projects could emerge [11, p. 18]. 


\section{Asia/Pacific}

Most of the world's LNG trade has centered in the Asia/Pacific region, which accounts for about threequarters of all LNG trade [9, p. 39]. Indonesia, Malaysia, and Australia are the primary exporters, and Japan, South Korea, and Taiwan are the main consumers. These six countries will most likely remain the centerpiece of LNG trade, joined by a few Middle Eastern countries such as Oman and Qatar.

Although neither country will operate at a level comparable to those above, both Burma (Myanmar) and Thailand have the potential for significant growth in natural gas production. Plans to increase gas consumption in Thailand have been spurred by the recent flow of gas from a domestic field. Burma, with even larger gas reserves, could develop them if a strong enough market can be found. Thailand is one of the possible markets $[9$, p. 39; 13, p. 22].

Coal has been the major source of energy in China for many years, and it is extremely unlikely that gas will be a threat to coal's dominance any time in the near future. However, China has substantial gas reserves, and its clean-burning qualities make it an attractive alternative to relatively dirty coal. Recent activity in China indicates possible interest in developing the country's natural gas industry. A project to upgrade and expand the gas industry in Sichuan province, sponsored by the World Bank, recently got underway. By the end of the century, this project could expand regional production by more than 20 percent. Another part of the project includes upgrading a pipeline system that is ". . 12-20 years old and prone to breakdowns, accidents, and leaks due to corrosion" [14, pp. 33-34].

China could also play a role in the highly ambitious pan-Asian pipeline project, which would link a large portion of Southeast Asia. The project is still in the discussion stages, and no firm commitments have been made. If the 27,000-kilometer pipeline project does take place, many of the gas-rich nations of the region will be connected to potential markets via pipeline. Among the possible countries involved are Japan, China, South Korea, Taiwan, Hong Kong, Thailand, Malaysia, Indonesia, Brunei, the Philippines, Australia, and Russia (Sakhalin Island) [9, p. 39].

\section{References}

1. Energy Information Administration. Annual Energy Outlook 1995. DOE/EIA-0383(95). Washington, DC, January 1995.

2. National Energy Board. Canadian Energy: Supply and Demand. Ottawa, Ontario: Minister of Supply and Services Canada, August 1994.

3. National Petroleum Council. The Potential for Natural Gas in the United States. Washington, DC, 1992.

4. "Latin American Gas Industry Poised for Enormous Growth." Gas World International, Vol. 199, No. 4906. August 1994. p. 10.

5. V. Thomas. "Massive Potential for Gas Development Highlighted." Gas World International, Vol. 199, No. 4907. September 1994. pp. 5, 22-23.

6. "New Network for South America." Petroleum Economist, Vol. 61, No. 11. November 1994. p. 23.

7. "France Signs Up for More Gas." Petroleum Economist, Vol. 61, No. 7. July 1994. p. 67.

8. N. Potter and V. Thomas. "Gas in Europe." Petroleum Economist, Vol. 61, No. 10. October 1994. pp. ixiii.

9. V. Thomas. "Global Industry Back on Track for Strong Growth." Petroleum Economist, Vol. 61, No. 9. September 1994. pp. 36-39.

10. T. Land. "Economic Restructuring Gives Gas a Boost." Gas World International, Vol. 199, No. 4905. July 1994. pp. 18-20.

11. Pipeline \& Gas Journal. August 1994. pp. 18-23, 5054.

12. Pipeline \& Gas Journal. June 1994. pp. 1-2.

13. "Offshore Developments Lean Towards Natural Gas." Petroleum Economist, Vol. 61, No. 8. August 1994. p. 22.

14. "Additional Details Spelled Out on Large Sichuan Gas Project." Oil and Gas Journal, Vol. 92, No. 24. June 13, 1994. pp. 33-34. 


\section{Coal}

\section{Environmental issues notwithstanding, coal remains a major energy source for electricity generation. Coal use is projected to grow worldwide, but its share of total energy consumption declines slightly.}

Between 1990 and 2010, coal ranks second-after oilamong all energy sources in terms of primary energy consumption. The amount of coal consumed is expected to increase by 27 percent during the projection period, from 5,172 million short tons in 1990 to 6,551 million short tons in 2010. Increased coal use in China alone is expected to account for more than three-fourths of the projected increase. Coal consumption worldwide in 2010 could be as high as 7,379 million tons or as low as 5,840 million tons under alternate assumptions about economic growth rates and trends in energy intensity (Figure 36). Its share of total energy consumption rose slightly throughout the 1980s-from 26 to 27 percentbut is projected to decline to 25 percent in 2010 (Figure 37).

Figure 36. World Coal Consumption, 1970-2010

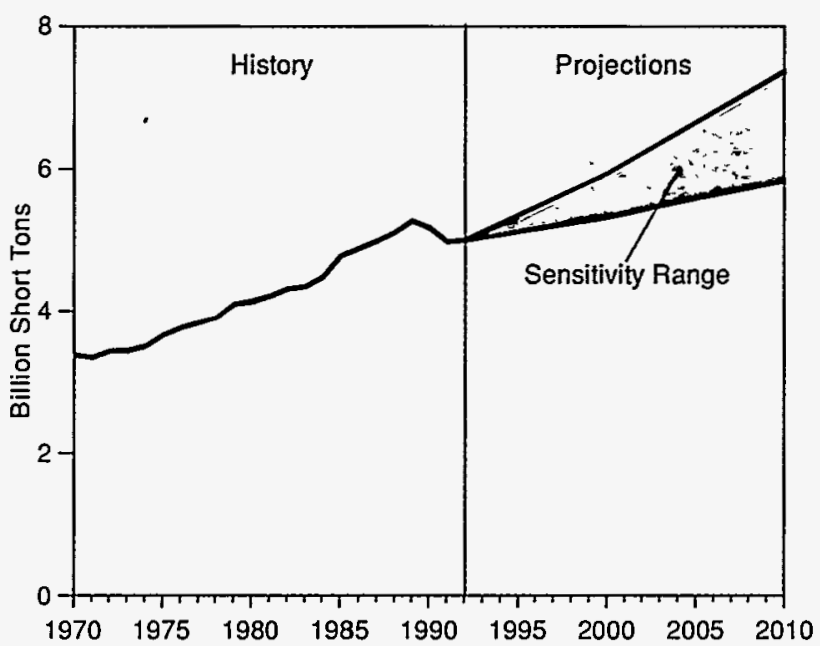

Sources: History: 1970-1979: Energy Information Administration (EIA), Office of Energy Markets and End Use, International Statistics Database. 1980-1992: EIA, International Energy Annual 1992, DOEI EIA-0219(92) (Washington, DC, January 1994). Projections: EIA, World Energy Projection System (1995).

\section{Consumption}

Coal is an economical energy resource that has been used intensively worldwide in the past and is expected to continue to play a strong role in the future. However, the combustion of coal produces several air pollutants that adversely affect ground-level air quality. In addition, coal has the highest carbon content of all
Figure 37. World Consumption of Coal Relative to All Other Energy Sources, 1970-2010

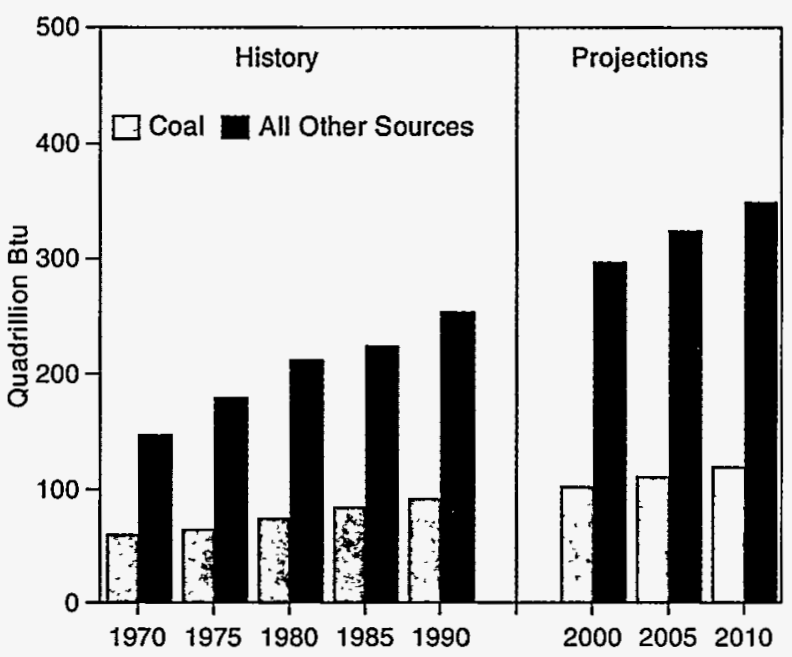

Sources: History: 1970-1979: Energy Information Administration (EIA), Office of Energy Markets and End Use, International Statistics Database. 1980-1992: EIA, International Energy Annual 1992, DOE/ EIA-0219(92) (Washington, DC, January 1994). Projections: EIA, World Energy Projection System (1995).

the fossil fuels, and its use is a major source of greenhouse gases. Thus, environmental concerns contribute to an expectation that coal's share of total energy consumption will decline slightly in the future. Before environmental regulations became a prominent issue, coal was seen as the leading source of fuel for future electricity generation. Since the 1970 s coal consumption has grown consistently (Table A5). In response to oil embargoes and price shocks, consumers began substituting more economical and secure supplies of coal for petroleum products.

Environmental issues notwithstanding, coal will remain a major energy source for baseload electric power generation in the future-particularly as oil and gas prices rise and "clean coal technology" advances. The use of coal to generate electricity will account for most of the projected growth in coal consumption worldwide, which grows by a little more than 1 percent annually over the projection period. Since 1990, however, world coal consumption has declined by just under 2 percent annually-primarily as a result of economic difficulties in Eastern Europe (EE) and the former Soviet Union 
(FSU) - in contrast to the 2-percent annual growth throughout the previous decade (Figure 36$)[1$, p. 28; 2 , p. 28].

Coal consumption is expected to grow most rapidly in the non-OECD Asia region, almost doubling from 30 to 53 quadrillion Btu between 1990 and 2010 (Figure 38). China alone accounts for more than 80 percent of the growth in the region. In the EE/FSU, on the other hand, as a result of the economic turmoil in the region, coal consumption is projected to decline by slightly more than 5 quadrillion Btu, with consumption in 2010 at only 15 quadrillion Btu. For the remaining regions of the world, including OECD North America and OECD Europe, slow growth in coal consumption is projected.

\section{Figure 38. World Coal Consumption by Region, 1970-2010}

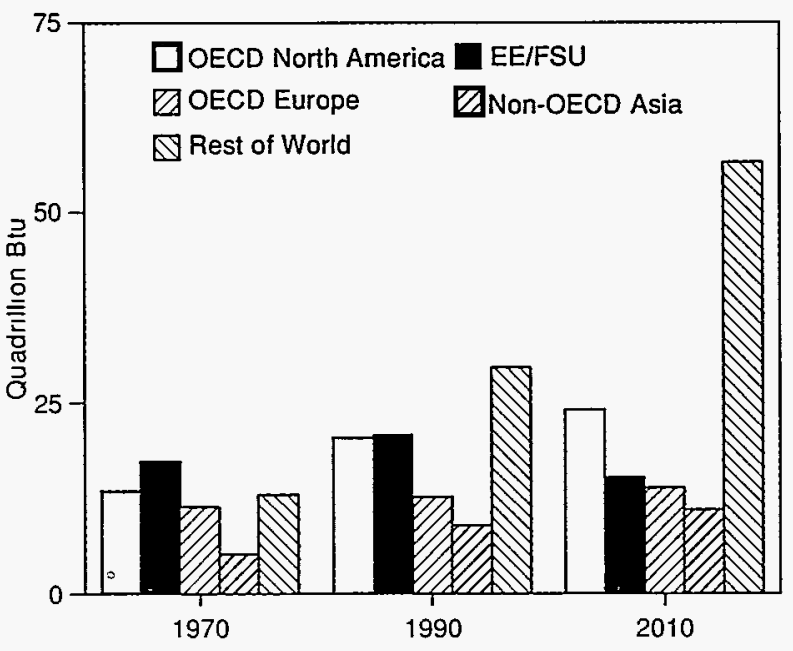

Sources: History: 1970-1979: Energy Information Administration (EIA), Office of Energy Markets and End Use, International Statistics Database. 1980-1992: EIA, International Energy Annual 1992, DOEI EIA-0219(92) (Washington, DC, January 1994). Projections: EIA, World Energy Projection System (1995).

\section{Reserves}

Coal resources are abundant in many parts of the world. The United States contains more than 90 percent of all North American reserves. Worldwide, the U.S. share is a substantial 23 percent (Figure 39). The FSU is another country with large endowments of coal reserves, which also represent 23 percent of the world total. China's reserves are less than half those of the leaders (11 percent of the world total), but China continues to lead the world in coal production $[1, \mathrm{pp} .106-$ 107]. At 1992 levels of consumption, world proven
Figure 39. World Coal Reserves

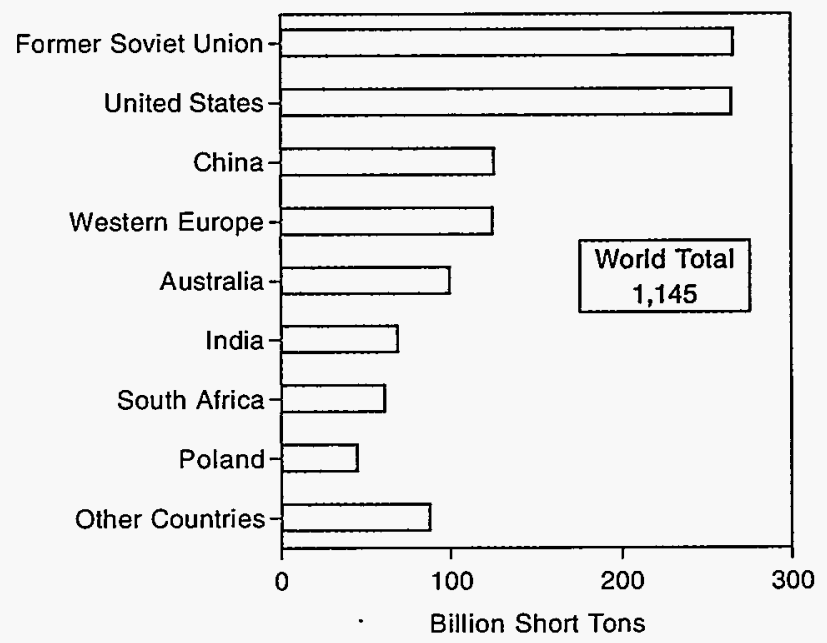

Note: Data shown for the United States represent recoverable reserves as of December 31, 1991. Data for all other countries are as of December 31, 1990.

Source: Energy Information Administration (EIA), International Energy Annual 1992, DOE/EIA-0219(92) (Washington, DC, January 1994.), Table 37.

reserves of coal would last for another 200 years [1, p. 104]. ${ }^{8}$ In contrast, current proved oil reserves correspond to 100 years of production, and natural gas reserves would sustain 65 years of production (although gas reserves have increased so dramatically in the past few decades that this number is most likely conservative).

\section{Trade}

In the past few years, several events have affected world coal production and consumption and, consequently, trade (Table 20). The dramatic decline in coal production in the EE/FSU region, caused mainly by the breakup of the FSU, led to a substantial decline in exports from those countries. While the market for coal has deteriorated in the EE/FSU, it has begun to expand and is projected to continue to grow in Asia, where consumption, production, and trade all are projected to increase.

Rapidly emerging low-cost producers will be the primary beneficiaries of the expanding international trading arena. Increased emphasis on cleaner coals gives new producers a significant marketing advantage, since their reserves include coal with very low sulfur content. Indonesia, which had almost no coal production or exports at the beginning of the 1980s and

\footnotetext{
${ }^{8}$ Proven reserves are those quantities of coal which geological and engineering information indicates with reasonable certainty can be recovered in the future from known deposits under existing economic and operating conditions.
} 
Table 20. World Coal Flows by Importing and Exporting Regions, Reference Case (Million Short Tons)

\begin{tabular}{|c|c|c|c|c|c|c|c|c|c|c|c|c|}
\hline \multirow[b]{3}{*}{ Exporters } & \multicolumn{12}{|c|}{ Importers } \\
\hline & \multicolumn{4}{|c|}{ Steam } & \multicolumn{4}{|c|}{ Metallurgical } & \multicolumn{4}{|c|}{ Total } \\
\hline & Europe & Asia & Other & Total & Europe & Asia & Other & Total & Europe & Asia & Other & Total \\
\hline & \multicolumn{12}{|c|}{1990} \\
\hline Australia . & 11 & 41 & 0 & 54 & 14 & 48 & 2 & 63 & 24 & 89 & 2 & 117 \\
\hline United States $\ldots \ldots \ldots$ & 24 & 6 & 11 & 42 & 35 & 14 & 12 & 63 & 59 & 21 & 23 & 106 \\
\hline South Africa $\ldots \ldots \ldots$ & 31 & 18 & 1 & 50 & 0 & 4 & 0 & 4 & 32 & 22 & 1 & 54 \\
\hline Former Soviet Union . . . & 14 & 3 & 0 & 18 & 13 & 6 & 0 & 25 & 27 & 9 & 0 & 43 \\
\hline Poland $\ldots \ldots \ldots \ldots$ & 23 & 0 & 0 & 19 & 4 & 0 & 3 & 12 & 27 & 0 & 3 & 31 \\
\hline Canada $\ldots \ldots \ldots \ldots$ & 1 & 3 & 1 & 5 & 3 & 26 & 2 & 30 & 4 & 28 & 3 & 34 \\
\hline China $\ldots \ldots \ldots \ldots$ & 3 & 8 & 0 & 17 & 0 & 1 & 0 & 2 & 3 & 9 & 0 & 19 \\
\hline South America . . . . . . . & 11 & 1 & 2 & 16 & 0 & 0 & 0 & 1 & 11 & 1 & 2 & 17 \\
\hline Other $^{\mathrm{a}} \ldots \ldots \ldots \ldots$ & 11 & 5 & 0 & 14 & 5 & 0 & 0 & 6 & 16 & 5 & 0 & 20 \\
\hline \multirow[t]{2}{*}{ Total } & 130 & 84 & 15 & 236 & 74 & 100 & 18 & 205 & 204 & 184 & 33 & 441 \\
\hline & \multicolumn{12}{|c|}{2000} \\
\hline Australia $\ldots \ldots \ldots \ldots$ & 0 & 89 & 0 & 89 & 9 & 68 & 5 & 82 & 9 & 156 & 5 & 171 \\
\hline United States $\ldots \ldots \ldots$ & 34 & 4 & 7 & 45 & 23 & 5 & 14 & 42 & 57 & 10 & 20 & 87 \\
\hline South Africa $\ldots \ldots \ldots$ & 39 & 22 & 4 & 65 & 0 & 4 & 0 & 4 & 39 & 26 & 4 & 69 \\
\hline Former Soviet Union ... & 8 & 6 & 0 & 14 & 4 & 5 & 0 & 8 & 11 & 11 & 0 & 22 \\
\hline Poland $\ldots \ldots \ldots \ldots$ & 13 & 0 & 0 & 13 & 9 & 0 & 0 & 9 & 21 & 0 & 0 & 21 \\
\hline Canada $\ldots \ldots \ldots \ldots$ & 5 & 3 & 1 & 8 & 6 & 21 & 1 & 28 & 11 & 24 & 2 & 36 \\
\hline China $\ldots \ldots \ldots \ldots$ & 0 & 20 & 0 & 20 & 0 & 3 & 0 & 3 & 0 & 24 & 0 & 24 \\
\hline South America . . . . . . & 25 & 0 & 18 & 43 & 0 & 0 & 0 & 0 & 25 & 0 & 18 & 43 \\
\hline Other $^{b} \ldots \ldots \ldots \ldots$ & 4 & 21 & 4 & 33 & 0 & 0 & 0 & 0 & 4 & 29 & 0 & 33 \\
\hline \multirow[t]{2}{*}{ Total $\ldots \ldots \ldots \ldots$} & 128 & 173 & 30 & 331 & 51 & 107 & 19 & 177 & 179 & 279 & 49 & 508 \\
\hline & \multicolumn{12}{|c|}{2010} \\
\hline Australia $\ldots \ldots \ldots \ldots$ & 13 & 147 & 0 & 160 & 12 & 66 & 5 & 82 & 25 & 212 & 5 & 242 \\
\hline United States $\ldots \ldots \ldots$ & 44 & 9 & 8 & 61 & 26 & 15 & 12 & 53 & 70 & 24 & 20 & 114 \\
\hline South Africa $\ldots \ldots \ldots$ & 29 & 52 & 7 & 88 & 0 & 4 & 0 & 4 & 29 & 56 & 7 & 92 \\
\hline Former Soviet Union . . . & 9 & 6 & 0 & 15 & 4 & 5 & 0 & 9 & 13 & 11 & 0 & 24 \\
\hline Poland $\ldots \ldots \ldots \ldots$ & 15 & 0 & 0 & 15 & 9 & 0 & 0 & 9 & 23 & 0 & 0 & 23 \\
\hline Canada $\ldots \ldots \ldots \ldots$ & 7 & 8 & 1 & 16 & 6 & 9 & 1 & 16 & 13 & 16 & 2 & 31 \\
\hline China $\ldots \ldots \ldots \ldots$ & 0 & 28 & 0 & 28 & 0 & 3 & 0 & 3 & 0 & 31 & 0 & 31 \\
\hline South America . . . . . & 53 & 0 & 22 & 75 & 0 & 0 & 0 & 0 & 53 & 0 & 22 & 75 \\
\hline Other $^{b} \ldots \ldots \ldots \ldots$ & 11 & 34 & 0 & 45 & 0 & 0 & 0 & 0 & 11 & 34 & 0 & 45 \\
\hline Total $\ldots \ldots \ldots \ldots$ & 181 & 283 & 38 & 502 & 56 & 102 & 18 & 176 & 237 & 385 & 56 & 678 \\
\hline
\end{tabular}

ancludes principally Indonesia's trade within Asia, as well as the United Kingdom and Germany's trade within Europe.

'Does not include the United Kingdom and Germany's trade within Europe.

Note: Totals may not equal sum of components due to independent rounding. The sum of the columns may not equal the total, because the total includes a balancing item between importers' and exporters' data. In the case of China and the former Soviet Union, the balancing item for 1990 amounted to between 5 and 7 million short tons.

Sources: History-Energy Information Administration (EIA), Office of Integrated Analysis and Forecasting estimates. Projections-EIA, Annual Energy Outlook 1995, National Energy Modeling System run AEO95B.D1103942. 
exported only 5 million tons in 1990, exported 25 million tons in 1992 [1, p. 12]. Indonesia is projected to supply 45 million tons to international markets by 2010 . Venezuelan and Colombian production is also climbing steadily. South American producers are expected to export approximately 75 million tons by 2010 .

Both India and China are expected to build new electric power generating plants in the future, probably using imported coal as their fuel source. (China will import coal because doing so will be more economical than mining and shipping its own coal to the sites of the new generating units.) The planned increases in coal trading markets contribute to a projected increase in coal trade in the future [3, p. 116]. Already in position to benefit from the plans for expanded consumption in the Asian market, Asia's own export suppliersIndonesia and China-are making considerable advances in the export market. They are projected to supply 76 million tons by 2010 . There is speculation that prices will rise as the market tightens; however, China is expected to seek a higher level of market penetration, and the resulting expansion of supply could moderate any price increases.

The Pacific Rim countries are expected to be the fastest growing markets for coal over the projection period, and the countries supplying the region should benefit from its growth. For example, Australia's exports should more than double by 2010 as Asian import supply continues to be dominated by Australian coal, which is projected to supply 55 percent of the region's total imports in 2010. Australia's exports to Japan should grow by about 30 percent over the projection period, but its market share there will fall slightly as Japan continues to diversify its sources of supply. To compensate, Australia is expected to expand its exports to other Asian markets. Meanwhile, U.S. producers' share of the Asian coal market is projected to decline, garnering only 6 percent in 2010. North American suppliers, physically distant from the major areas of growth, are projected to supply only 10 percent of total Asian import demand in 2010.

The major factors influencing coal consumption have different impacts on steam coal (used primarily for electricity generation) than on metallurgical coal (used mostly for steelmaking). There is world coal trade in both types of coal. Historically, metallurgical coal was the predominant type traded in international markets. While metallurgical coal continues to play a significant role in international coal trade, by 2010 it is projected to account for only 26 percent of the total, down from 46 percent in 1990 (Figure 40).
Figure 40. World Coal Trade, 1980-2010

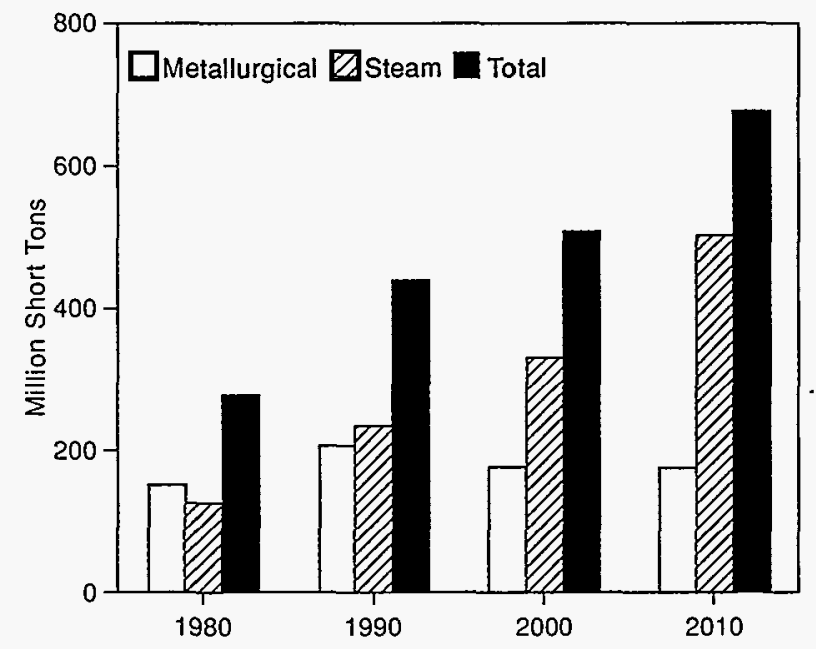

Sources: History: Energy Information Administration (EIA), estimates from the Office of Integrated Analysis and Forecasting. Projections: EIA, Annual Energy Outlook 1995, National Energy Modeling System run AEO95B.D1103942.

Electricity markets are projected to dominate the future of world coal trade, as electricity consumption grows in importance in most countries with developing economies. The amount of coal required for electric power generation is influenced by factors such as weather, levels of generation from alternative sources (such as nuclear and hydro), economic growth, and the penetration of a wide range of electrical services in all economic sectors. Coal is the leading fuel source for electric power generation in the OECD [3, p. 34], but most of the growth in trade will be in non-OECD areas, where high rates of electrification are occurring, fueled increasingly by coal. New technologies for other traditional coal uses are also affecting coal trade. In steelmaking, for example, the increasingly popular pulverized coal injection ( $\mathrm{PCI}$ ) technology, in which steam coal displaces some of the coal coke in blast furnace charges, is making inroads.

\section{Regional Activity}

As a result of fast-paced economic growth in the region, coal consumption is expected to grow most rapidly in non-OECD Asia (Figure 38), which is projected to account for 44 percent of total world coal consumption by 2010, compared with 31 percent in 1990. Consumption in the region grows by 84 percent, from 1,581 to 2,904 million tons (Table A5). China, alone, is expected to increase its coal consumption by 1,103 million tons, nearly doubling the current level of 
domestic consumption. Assuming no change in environmental policies in China, coal should continue to provide close to three-quarters of all energy consumed there in 2010.

In the world as a whole, on the other hand, the consumption of coal relative to other fuels will drop slightly, to 25 percent of total energy consumption. European markets have sagged in the past few years, contributing to the recent downward trend in world coal consumption, but they are projected to turn around as early as the mid-1990s. While European markets are projected to improve in the future, they are not expected to return to their previous dominance in the world market. Environmental concerns in Western Europe play an important role in the competition among coal, natural gas, and nuclear power and have favored increased use of fuels other than coal in recent years. Nonetheless, European imports are projected to increase by 33 million tons over the forecast period. European imports seem destined to rise, even with strong support for new and more stringent antipollution regulations. Most Western European countries plan to reduce coal production subsidies, eliminate unprofitable mines, and replace their production with imported steam coal. In Eastern Europe the competition among energy sources will be primarily on economic grounds. Political and economic turmoil in Poland and Russia has sharply reduced coal exports since 1990. By 2010, Poland and Russia are projected to regain only about half of their pre-1990 export levels. As their economies recover, their own coal use should also rise.

The Japanese demand for coal imports over the forecast horizon is expected to remain the largest of any country. Coal imports will have to remain high to supply the coal needed for projected increases in electricity production. The International Energy Agency estimates that coal use for electricity generation in Japan will increase by more than 4 percent annually through 2000 [3, p. 47].

The exceptional economic growth in such newly industrialized countries as South Korea and Taiwan will give rise to large coal imports for those countries. The Pacific Rim countries, in general, are planning to add substantial amounts of coal-fired generating capacity, an important factor in giving Asia the largest share of projected coal import demand. In Asia overall, coal imports are projected to rise during the next two decades, from 184 million tons in 1990 to 385 million tons in 2010 (Table 20).

Currently, relatively small amounts of coal are traded between the countries of North America-the trade principally is between the United States and Canada. Historically, the United States has supplied nearly 100 percent of the coal imported by Canada-38 percent of its total coal consumption. U.S. producers should continue to meet most of Canada's coal import needs. However, as Canada develops other forms of electricity generation, steam coal import requirements have halved in the past few years, and they are likely to continue their decline. Meanwhile, U.S. coal imports, which are reaching historic highs, are projected to total 15 million tons by 2010 (1 percent of total U.S. coal consumption). Imported coals are high-quality, low-sulfur fuels, mostly from South America.

U.S. suppliers in past years have exported 10 percent of their annual production, and that share is projected to continue through 2010. Total U.S. exports of coal are projected to grow from 106 million tons in 1990 to 114 million tons in 2010. World trade will grow more rapidly. The United States should nevertheless retain its position as the world's second largest exporter-albeit with a declining market share. Asia is expected to provide the greatest opportunities for coal exports, and because of transportation costs, North American exporters will find it more difficult to compete with the coal-producing countries located near Asia-notably, Australia, China, and Indonesia.

Mexico is expected to become a coal importer in the future. New and currently planned Mexican power plants are to be fueled by oil, but a larger proportion of future plants will be coal-burning, because Mexico would prefer to export its oil. Based on the expectation that political roadblocks related to the construction of coal import facilities will be overcome, steam coal imports of 7 million tons are projected by 2010. U.S. and Canadian suppliers are projected to provide nearly 60 percent of Mexico's coal imports, with the remainder originating from South America.

Overall, the changes in regional coal market activities over the past decade have been significant. In physical terms, the growth in the Asian market has overshadowed the setbacks in European markets. However, environmental regulation is a major challenge to coal's future. In addition, competitive pressure from other fuels, particularly oil and natural gas, has intensified, in part because of low oil and gas prices and in part because of new technologies that favor the use of natural gas for electricity generation. Nevertheless, coal use is still projected to grow by 1.4 billion tons ( 28 percent) worldwide between 1992 and 2010, even as its share of total energy consumption declines by 1 percentage point. 


\section{References}

1. Energy Information Administration. International Energy Annual 1992. DOE/EIA-0219(92). Washington, DC, January 1994.
2. Energy Information Administration. International Energy Annual 1989. DOE/EIA-0219(89). Washington, DC, February 1991.

3. International Energy Agency. Coal Information 1992. Paris France, 1993. 


\title{
Nuclear Power
}

\begin{abstract}
Very little growth in nuclear electricity is projected through 2010. Rising costs, safety concerns, and waste management issues continue to plague the nuclear power industry around the world.
\end{abstract}

The first commercial nuclear power units came online in the 1960s. In the 1970s and early 1980s, electricity generation from nuclear power plants grew rapidly worldwide, as early programs were expanded and more countries developed nuclear technology. Nuclear power provided 3 percent of the total electricity generated in countries with nuclear power programs in 1970,12 percent in 1980, and 25 percent in 1985, but its share has remained fairly constant during the late 1980s and early 1990s [1]. The leveling off of nuclear power development can be attributed to several factors, including economic concerns, safety issues, and the problem of spent fuel and radioactive waste disposal.

Economic concerns stem from both the capital-intensive nature of nuclear power projects and the highly variable operating and maintenance costs across plants. Recent trends toward deregulation and privatization of electricity supply systems have put nuclear power plants under increasing pressure to be economically competitive with other generating technologies. Accidents at Three Mile Island in the United States in 1979 and at Chernobyl in the Ukraine in 1986 increased public concern about the safety of nuclear power plants in general. Along with technological safety enhancements, public confidence in the safety of nuclear power must increase before any growth in the industry can be expected. Additionally, spent fuel management and waste storage are creating problems that have yet to be solved. In the United States, for example, temporary onsite spent fuel storage pools are filling up with as yet no outlet for permanent storage. Theoretically, many options exist for either temporary storage or permanent disposal of the waste; however, they require significant funds that may not have been planned for, as well as significant time for research, construction, and regulatory approval.

Given these uncertainties, two scenarios were developed for projections in this report. The Lower Reference Case reflects a continuation of the present trends in the nuclear power industry, resulting in minimal growth. The Upper Reference Case reflects a moderate revival in nuclear orders. The Lower Reference Case projects growth in nuclear capacity of only 0.2 percent per year through 2010 (Figure 41). Half of the countries with nuclear power programs are projected to experience net
Figure 41. World Nuclear Capacity, 1980-2010

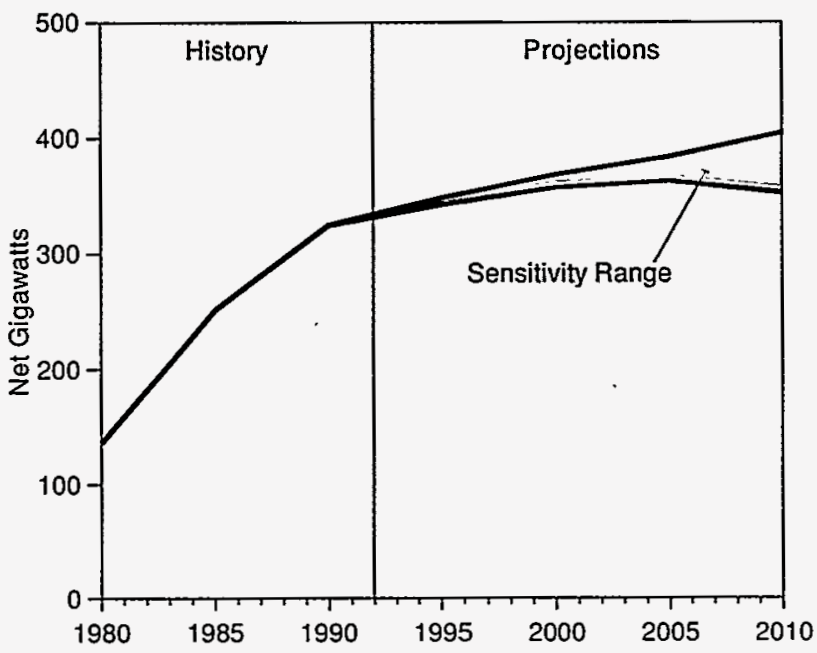

Sources: History: International Atomic Energy Agency, Nuclear Power Reactors in the World (Vienna, Austria, April 1993). Projections: Energy Information Administration, Office of Integrated Analysis and Forecasting, staff projections (1995); and World Nuclear Outlook 1994, DOE/EIA-0436(94) (Washington, DC, December 1994), p. 8.

growth in capacity between 1993 and 2010 (Table 21). Growth is projected mainly in developing countries-in particular, non-OECD Asia-which are just beginning their nuclear power programs (Figure 42). The Upper Reference Case projects net growth of 1 percent per year and a net increase in nuclear capacity by 2010 in 29 of the 36 countries with nuclear programs.

\section{Major Trends in World Nuclear Capacity}

Total electricity generation from nuclear power increased slightly in 1993, with production of 2,093 net terawatthours worldwide. The United States, France, Germany, Russia, Ukraine, and Japan accounted for more than 70 percent of the total. At the end of 1993 there were 430 operable units in 30 countries, with total net capacity of 338 gigawatts [2, pp. 4-5]. Worldwide consumption of electricity from nuclear power saw its greatest growth between 1970 and 1990 but is projected to remain fairly level through 2010 (Figure 43). Nuclear consumption is projected to grow at only 0.2 percent 
Table 21. Historical and Projected Operable Nuclear Capacities (Net Gigawatts)

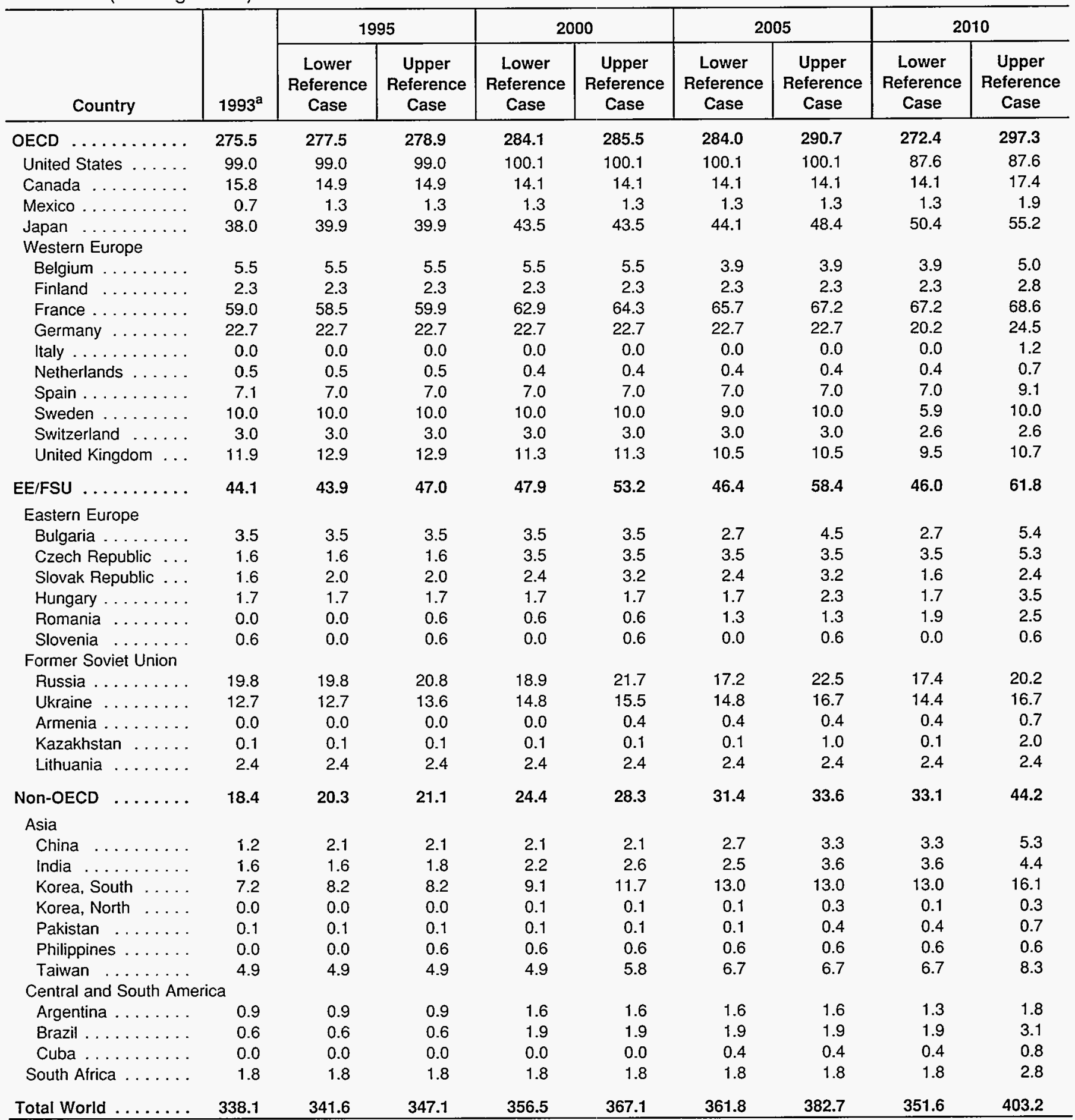

aStatus as of December 31, 1993.

Notes: OECD = Organization for Economic Cooperation and Development. EE/FSU = Eastern Europe/Former Soviet Union. Totals may not equal sum of components due to independent rounding. The Lower and Upper Reference Cases reflect varying degrees of optimism regarding nuclear power.

Sources: United States: Energy Information Administration, Annual Energy Outlook 1995, DOE/EIA-0383(95) (Washington, DC, January 1995), updated by staff projections, Office of Integrated Analysis and Forecasting, based on new information about units under construction (March 1995). Foreign: Energy Information Administration, World Nuclear Outlook 1994, DOE/EIA-0436(94) (Washington, DC, December 1994). 
Figure 42. World Nuclear Capacity by Region, 1970-2010

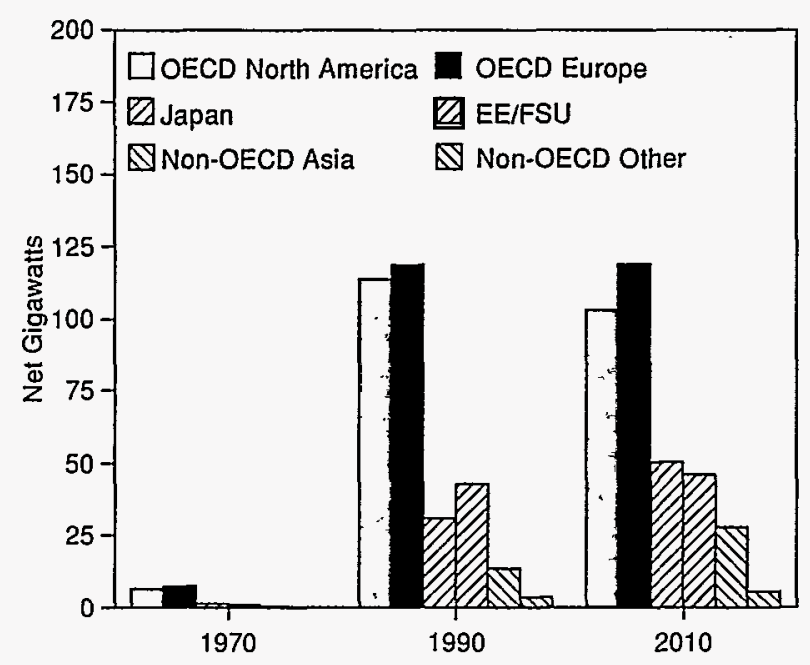

Sources: History: International Atomic Energy Agency, Nuclear Power Reactors in the World (Vienna, Austria, April 1993). Projections: Energy Information Administration, Office of Integrated Analysis and Forecasting, staff projections (1995); and World Nuclear Outlook 1994, DOE/EIA-0436(94) (Washington, DC, December 1994), p. 3.

per year from 1990 through 2010, while overall electricity consumption grows at 2.0 percent annually. Nuclear power was initially promoted as an improved alternative to traditional baseload electricity generation, without the carbon emissions produced by coal plants and cheaper than oil or natural gas. However, safety concerns have shifted public opinion against nuclear power, and few countries have been able consistently to build and operate the plants at the low costs promised. With the trend in electricity moving towards deregulation and privatization, the economic competitiveness of various generating technologies has become the overriding issue in decisions about future capacity.

A recent study from the OECD energy agencies compares projected costs to build new generation capacity to be licensed around 2000, using data provided by specific countries (16 of the OECD countries, 6 nonOECD countries) [3]. In comparing nuclear, coal, and gas-fired combined-cycle plants for baseload power, the ranking of nuclear power depends mainly on the discount rate used, because of its higher capital cost and longer construction time. At a five percent discount rate, nuclear power was projected to be cheaper than coal in all countries or regions except the United Kingdom, western Canada, and the western United States; and cheaper than gas in all countries except the United Kingdom. At a higher discount rate of 10 per-
Figure 43. World Consumption of Electricity From Nuclear Power Relative to All Other Fuels, 1970-2010

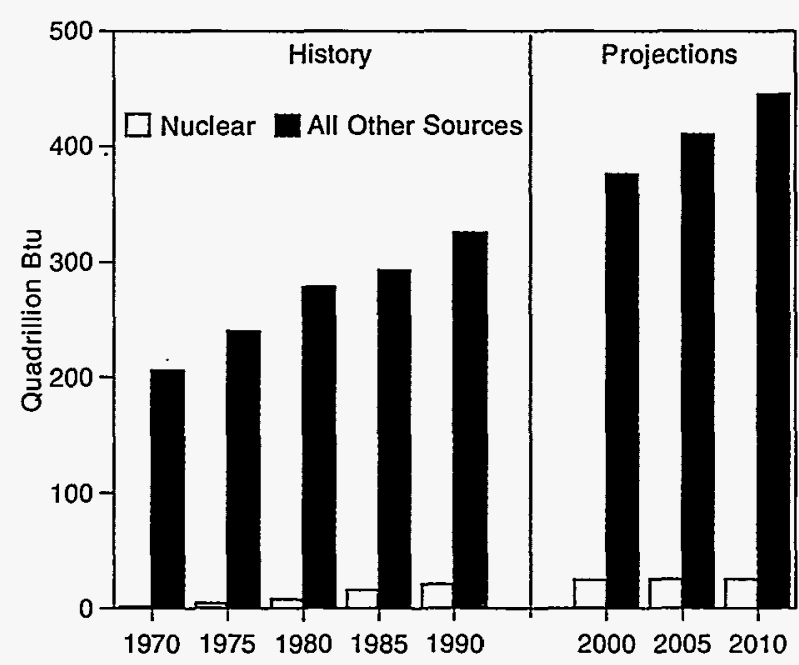

Sources: History: 1970-1979: Energy Information Administration (EIA), Office of Energy Markets and End Use, International Statistics Database. 1980-1992: EIA, International Energy Annual 1992, DOE/EIA-0219(92) (Washington, DC, January 1994). Projections: EIA, World Energy Projection System (1995).

cent, however, nuclear power was projected as the cheapest technology only in France and Japan. Investment costs were identified as the largest single component of nuclear generating costs, therefore, the results are sensitive to variations in this expense. Slight increases in capital costs or construction times will decrease the competitiveness of a nuclear power plant. Operating and maintenance costs are a less important factor, but they are still significant, especially in the United States, where they account for a larger percentage of total generation costs than in other countries.

In France, where nuclear power currently supplies almost 80 percent of total electricity generation, government studies continue to project nuclear power to be the cheapest source of baseload power. An indepth study by the French government integrates all costs applicable to nuclear power, including waste disposal, decommissioning, and research and development, and still finds nuclear power cheaper than fossilfuel alternatives [4, p. 1]. The French claim that the competitiveness of their program is due to economies achieved from building like plants rather than separate, isolated units. Other countries are hoping to follow a similar plan with future designs, with a joint European effort developing common regulatory standards for future designs and the United States creating one-step licensing for preapproved designs. 


\section{Regional Analysis}

\section{OECD Europe}

Western Europe relies heavily on nuclear power to satisfy its electricity demand, much more than any other region. At the end of 1993, Western Europe generated 43 percent of its electricity from nuclear power, with France and Belgium supplying 78 and 59 percent, respectively, of their country's demand from nuclear power [2, p. 4]. However, the trend in Western Europe is no longer toward increasing nuclear power builds. In the Lower Reference Case, only France is projected to see a net increase in nuclear capacity between 1993 and 2010, while seven other West European countries experience a decrease due to retirements and the lack of new orders. The Upper Reference Case projects overall growth of 13 gigawatts in the region, while the Lower Reference Case projects a decrease of 3 gigawatts.

In 1993, only one new unit was brought online in the OECD Europe region, as France began operation of Golfech 2, a 1,310-megawatt pressurized-water reactor (PWR). Two units were retired, the two Trawsfynydd units in the United Kingdom, which had been offline since 1991. At the end of 1993, France had eight units in the construction pipeline, and the United Kingdom had two units planned or under construction [2, p. 6].

The bleak outlook for nuclear power in Western Europe can be explained by different factors. Spain and Switzerland currently have a moratorium on nuclear plant construction, both continuing until at least 2000 . In Germany, despite successful operation of nuclear plants, public safety concerns remain strong, discouraging further expansion of nuclear capacity. Even France is cutting back on the rate of new nuclear builds; Electricite de France recently announced that no new nuclear units will be ordered before 2000 , because the country currently has excess generating capacity [5, p. 1].

\section{OECD Pacific}

Only Japan in the OECD Pacific region has a wellestablished nuclear program, with 48 units totaling 38 gigawatts operable at the end of 1993. Japan's nuclear share of total electricity generation was 31 percent in 1993. Japan has ambitious plans for further nuclear expansion, mainly to help achieve energy independence. In the Lower Reference Case, Japan is projected to increase its nuclear capacity by 12.4 gigawatts-to a total of 50.4 gigawatts in 2010. The Upper Reference
Case projects an increase in capacity to 55.2 gigawatts in 2010.

Four new nuclear units came online in Japan during 1992. Three boiling-water reactors (BWRs)-Hamaoka 4, Shika 1, and Kashiwazaki Kariwa 4-were connected to the grid, as well as one PWR-Genkai 3. The aggressive expansion plan for Japan's nuclear power industry listed 19 units totaling 20.1 gigawatts in the construction pipeline at the end of 1993 [2, p. 6]. In early 1994, one new unit had already been connected to the gridIkata 3, an 846-megawatt PWR [6, p. 19]. Japan's expansion includes plans to build reprocessing and recycling facilities to handle nuclear waste domestically.

\section{Non-OECD Asia}

Countries in Asia currently operating nuclear power plants include China, South Korea, Taiwan, India, and Pakistan. With the exception of South Korea, these programs are small, but all expect growth in the future. At the end of 1993 these five countries had 15.0 gigawatts of nuclear capacity online. By 2010, additional programs are expected to be operating in the Philippines and North Korea, and nuclear capacity for the region is projected to be between 27.7 and 35.7 gigawatts. South Korea, currently the largest operator of nuclear power in the region with nine units operable, totaling 7.2 gigawatts, projects a doubling of capacity, to between 13.0 and 16.1 gigawatts by 2010 .

During 1993 one new unit became operable in the nonOECD Asia region, Guangdong 1, a 906-megawatt PWR located in China. At mid-year 1994, China brought another new unit on line, the 906-megawatt PWR, Guangdong 2 [7, pp. 58-59]. At the end of 199324 units were under construction or on order in non-OECD Asia countries, including 7 in South Korea $[2$, p. 6]. China has announced aggressive plans to build additional nuclear power plants to meet rapid growth in electricity demand. It recently agreed to purchase two Candu heavy-water reactors from Canada $[8$, p. 1$]$.

\section{North America}

The nuclear program in the United States is much larger than those of the two other countries in the region, however, reliance on nuclear power is very similar in the United States and in Canada. In 1993, the nuclear share of electricity in the United States was 19 percent; in Canada it was 17 percent. Mexico operates only one small nuclear unit, which provided 3 percent of the country's electricity during 1993. Little or no growth is expected in this region. In the United States, nuclear capacity is projected to increase slightly 


\section{Nuclear Waste Issues}

Electricity is generated in nuclear power reactors by a series of controlled chain reactions, which alter the chemical makeup of the nuclear fuel. Eventually, changes occur so that a reaction will no longer take place, and the plant is shut down for refueling, which involves discharging the spent fuel and replacing it with fresh nuclear fuel. The spent fuel, which is highly radioactive, is then typically stored on site, initially in pools that provide both cooling and shielding of the environment. Other interim storage options include dry, aboveground facilities either at the reactor site or at a common facility for multiple reactors. An alternative to storage of the spent fuel is chemical reprocessing. Reprocessing separates out materials that can be recycled into nuclear fuel, leaving a smaller amount of radioactive waste for disposal. Reprocessing is a controversial option, however, because plutonium, which is among the materials recovered, can be converted for weapons use as well as for electricity generation. Ultimately, either the spent fuel or the reprocessing waste must be isolated from the environment until radioactivity is diminished to safe levels. Finding the proper sites and facilities for this purpose has proved difficult.

The majority of European countries, as, well as China and Japan, have identified reprocessing as their strategy for spent fuel management [9]. Reprocessing facilities are in operation in France, the United Kingdom,
Russia, and Japan. However, plants in France are now generating spent fuel faster than it can be reprocessed. Therefore, France is looking into the construction of an off-site spent fuel storage facility [10, p. 9]. In Russia, a law passed in 1994 prohibits imports of foreign nuclear waste into Russia. This is causing significant problems in countries such as Finland, Bulgaria, and the Ukraine, which had contracts with Russia to reprocess their spent fuel. Those countries are now forced to develop additional on-site storage, and to rethink their plans for future waste management.

The less developed countries are mainly developing interim storage options as a means to delay the spent fuel decision. Interim storage leaves the fuel above the ground, either in pools or in dry storage, but it is not a permanent solution. The United States, Canada, and Sweden have committed to permanent disposal of all waste, with no reprocessing. However, difficulties in finding appropriate sites and completing the necessary research for construction of the actual facilities have forced these countries also to develop additional interim storage. In the United States, a number of utilities have been successful in construction of independent spent fuel storage installations (aboveground dry storage facilities on site), and others hope to follow; however, problems are likely to stem from political issues and public opposition [11, p. 35]. through 2005 (as one unit under construction is completed), then to decrease by 13 percent because of retirements and the lack of new orders. In Canada, the Lower Reference Case projects no new orders, with capacity decreasing by 2010 due to retirements, whereas the Upper Reference Case projects a slight revival in nuclear orders and an increase in capacity of 1.6 gigawatts over the forecast period.

During 1993 two new nuclear units were connected to the grid in North America. In the United States, Comanche Peak 2, a 1,150-megawatt PWR, began operation in April. In Canada, Darlington 4, an 881-megawatt pressurized heavy-water-moderated and cooled reactor (PHWR) was brought online. One nuclear unit was retired during 1993, the Trojan unit, a 1,104-megawatt PWR in the United States. The owners chose to retire the unit 19 years before its operating license expired, rather than incur costs necessary to replace the plant's steam generators. The construction pipeline at the end of 1993 included seven units under construction or planned in the United States; however, all but oneWatts Bar 1, in Tennessee-are indefinitely deferred or have since been canceled. Canada has no units under construction, and Mexico has only one new unit planned [2, p. 6].

In the United States, the Tennessee Valley Authority has stopped construction on three nuclear units-Watts Bar 2 and the two Bellefonte units [12, p. 5]. The units may still be completed if a financial partner can be found, but conversion of the units to operate with a different fuel is also under consideration.

\section{Eastern Europe/Former Soviet Union}

In the EE/FSU region, 18 percent of the total electricity supply was generated from nuclear plants during 1993, with nearly 80 percent of the nuclear generation produced in the FSU $[2$, p. 4]. Reliance on nuclear power 
varies in this region, with Lithuania supplying almost 90 percent of its electricity from nuclear power, while Russia's nuclear share is only 13 percent. Several countries in the region have ambitious plans for additional nuclear capacity; however, the many challenges now facing the region will likely limit new nuclear builds before 2010. The Lower Reference Case projects a net increase of only 1.9 gigawatts throughout the region between 1993 and 2010, with decreases in nuclear capacity in Bulgaria, Slovenia, and Russia. The Upper Reference Case projects an increase of 17.7 gigawatts, implying that financial and safety concerns will be resolved, allowing planned additions to be completed on schedule.

In 1993, Balakovo 4, a 950-megawatt PWR, entered service in Russia, the first unit to do so since the collapse of the Soviet Union. Eastern Europe and the FSU have aggressive plans to build new capacity, with 28 units in the pipeline, but the ability to complete those units may depend both on obtaining financial support and on improving safety at existing units. Since the accident at the Chernobyl plant in the Ukraine in 1986, the safety of East European reactors has been a worldwide concern. The Chernobyl plant is a lightwater-cooled, graphite-moderated reactor (known as an RBMK), which most experts agree is an intrinsically unsafe design. There are currently 15 RBMK reactors in operation in Russia, Ukraine, and Lithuania (excluding four research reactors in Russia). Short-term safety improvements have been made, but most Westerners agree that the goal should be to shut down the plants. There are also concerns that any aid money given to $\mathrm{EE} / \mathrm{FSU}$ countries to improve safety may simply extend the operation of the unsafe reactors. In fact, a recent report from the U.S. General Accounting Office questions the value of aid to these high-risk reactors, saying that money is being given without assurance that reactors that are unable to be upgraded will be shut down. Currently, the G-7 nations have pledged more than $\$ 785$ million to the former Soviet states to improve nuclear plant safety, and $\$ 57$ million has been spent so far with no clear sign of improvements in the reactors [13, p. 1].

Eastern Europe faces several problems in trying to shut down unsafe plants. In most cases, the power generated by such plants cannot be supplied by any currently available alternatives. In Lithuania, two RBMK reactors provide almost 90 percent of the country's electricity as well as a portion for export. The Ukrainian parliament originally voted to shut down permanently the two remaining reactors at the Chernobyl site by the end of 1993, but the units are still operating to alleviate energy shortages in the area. The issue is further complicated by the fact that little is known about the cost and procedure of decommissioning, including what will be done with the radioactive waste. In Russia, reactors will not be shut down until alternative power sources are available. One possible option-increased use of natural gas-is not feasible from an economic standpoint because of the need for hard currency, which is obtained when natural gas is exported.

Much of the money pledged to improve safety in Eastern Europe has gone to studies and reports of the situation, rather than to actual safety equipment or training. At issue is the concern by the United States and other nations that they will be held liable for damages, if an accident occurs at a plant where they have supplied equipment or performed repair work. There are also concerns on both sides that the goals of the East and West with respect to the Eastern Europe nuclear power industry are quite different. The West fears that the reactors will continue to be run without meeting Western safety standards until another accident occurs and is, therefore, pursuing the shutdown of old reactors and replacement with new nuclear units. The East has suggested that this proposal may be an attempt by the nuclear industry to increase business when orders have declined elsewhere, and would prefer to continue operation of existing units by retrofitting them with the necessary safety enhancements. They are also reluctant to increase their dependency on Western technology.

\section{References}

1. International Energy Agency/Organization for Economic Development. IEA Statistics: World Energy Statistics and Balances. Paris, France: June 1991.

2. Energy Information Administration. World Nuclear Outlook 1994. DOE/EIA-0436(94). Washington, DC, December 1994.

3. Nuclear Energy Agency/International Energy Agency. Projected Costs of Generating Electricity. Washington, DC, December 1992.

4. "Nuclear Stays France's Cheapest Power Even With Backend Costs." Nucleonics Week, Vol. 34, No. 21. May 27, 1993.

5. "No More Nuclear Plant Orders for EdF Before End of Century." Nucleonics Week, Vol. 35, No. 25. June 23, 1994.

6. "World Survey." Nuclear Engineering International. June 1994. 
7. "World List of Nuclear Power Plants." Nuclear News. September 1994.

8. "AECL Closes in on China Reactor Sale." The Energy Daily, Vol. 22, No. 215. November 9, 1994.

9. "Spent Fuel Management and Transport 1994." Supplement to Nuclear Engineering International. December 1994.

10. "EdF Postpones Spent Fuel Storage Project, Will Use LaHague Pools." Nuclear Fuel, Vol. 18, No. 21. October 11, 1993.
11. "Onsite Dry Spent-Fuel Storage: Becoming More of a Reality." Nuclear News. December 1993.

12. "TVA Drops Watts Bar-2, Bellefonte as Nuclear Construction Projects." Nucleonics Week, Vol. 35, No. 50. December 15, 1994.

13. "GAO Questions Value of Aid to High-Risk Soviet Reactors." Nucleonics Week, Vol. 35, No. 44. November 3, 1994. 



\title{
Hydroelectric and Other Renewable Energy
}

\author{
Hydroelectricity is only a small part of overall world energy consumption, despite \\ its importance in some regions. Fast-paced growth is projected for hydroelectric \\ and other renewable fuels, but their share of total energy use remains low.
}

Electricity generated from hydroelectric dams and other renewable energy sources-primarily geothermal and wind, biomass, and solar power-is expected to continue fast-paced growth throughout the projection period. Consumption of renewable energy sources grows by 2.3 percent per year between 1990 and 2010, compared with 1.6-percent annual growth in overall energy consumption. Consumption of hydroelectricity and other renewables combined is expected to be between 37 and 46 quadrillion Btu in 2010 (Figure 44). The renewable share of total primary energy consumption, however, remains small relative to the shares of other energy sources. In 2010, renewable energy sources are projected to account for 9 percent of the total world energy consumption, with fairly steady increases expected for most regions where they are currently exploited (Figure 45 and Table A7). More than half of the energy derived worldwide from these sources should continue to be utilized by the OECD countries (Figure 46).

The projections in this report do not include noncommercial fuels from plant and animal sources. While

Figure 44. World Consumption of Hydroelectricity and Other Renewables, 1970-2010

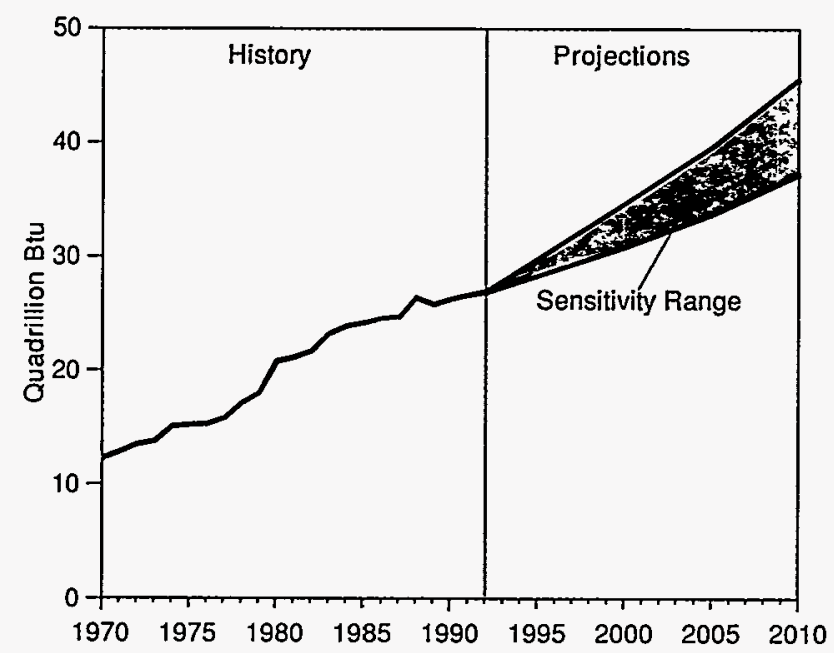

Sources: History: 1970-1979: Energy Information Administration (EIA), Office of Energy Markets and End Use, International Statistics Database. 1980-1992: EIA, International Energy Annual 1992, DOE/ EIA-0219(92) (Washington, DC, January 1994). Projections: EIA, World Energy Projection System (1995).
Figure 45. World Consumption of Hydroelectricity and Other Renewables Relative to All Other Fuels, 1970-2010

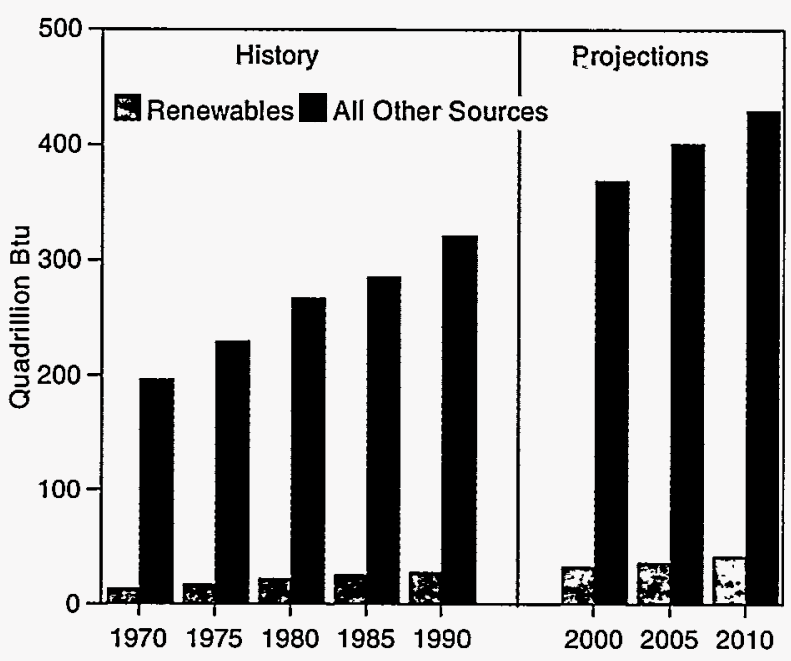

Sources: History: 1970-1979: Energy Information Administration (EIA), Office of Energy Markets and End Use, International Statistics Database. 1980-1992: EIA, International Energy Annual 1992, DOEI EIA-0219(92) (Washington, DC, January 1994). Projections: EIA, World Energy Projection System (1995).

the noncommercial fuels are important energy sources, particularly in developing countries, there are no comprehensive data available on their use. In addition, there are few comprehensive international data available on the use of dispersed renewables-renewable energy consumed on the site of its production (e.g., solar panels used for hot water heating). Dispersed renewables, therefore, are not considered in the projections.

Growth of renewable energy sources is expected to be particularly strong in non-OECD Asia (both China and Other Asia) and in the North American countries of Canada and Mexico. Between 1990 and 2010, consumption of renewable energy is expected to increase by more than 6 percent per year in China, and by 3 percent per year in Other Asia, Canada, and Mexico. In the United States, consumption of renewables is expected to grow more slowly (2 percent per year over the projection period), and most of the U.S. growth is attributable to renewable sources other than hydroelectricity [1, p. 94]. 
Figure 46. World Consumption of Hydroelectricity and Other Renewables by Region, 1970-2010

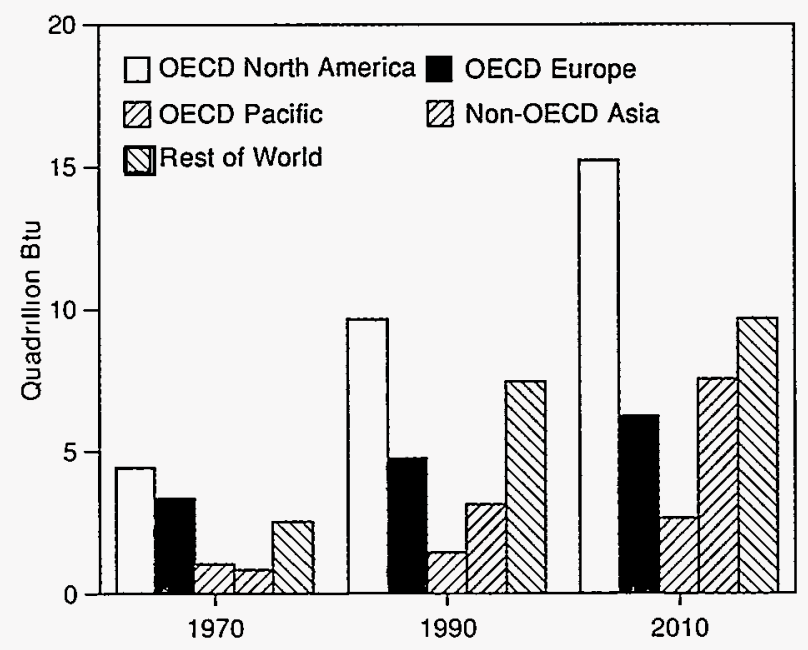

Sources: History: 1970-1979: Energy Information Administration (EIA), Office of Energy Markets and End Use, International Statistics Database. 1980-1992: EIA, International Energy Annual 1992, DOE/EIA-0219(92) (Washington, DC, January 1994). Projections: EIA, World Energy Projection System (1995).

Hydroelectricity remains a small factor in terms of world energy consumption, but it is important regionally. For example, in Canada, in the developing countries of non-OECD Asia, and in Central and South America, hydroelectricity is the dominant source of renewable energy. Renewable energy sources such as geothermal, wind, biomass, and solar power are the object of continued research, especially in the European countries of the OECD. These renewables have only been used on a small scale so far, and they currently represent only 1.5 percent of the installed generating capacity from hydroelectric and other renewable energy sources [2, p. 95]. Growth in the development of renewable resources other than hydroelectricity has been slowed because of the abundant supply and competitive cost of fossil fuels. Realistically, they cannot be expected to contribute much to the worldwide energy balance through 2010 .

\section{North America}

In the three countries of OECD North America (Canada, Mexico, and the United States), consumption of hydroelectricity and other renewables is projected to grow from about 10 quadrillion Btu in 1990 to 15 quadrillion Btu in 2010 in the Reference Case (Figure 46). This represents a growth rate of 2.4 percent per year over the 20-year period. Growth is expected to be particularly strong in Canada, where hydroelectric development is planned in most of the country's provinces. An increase of almost 74 percent is projected for Canada between 1990 and 2010, from 3 quadrillion Btu to 5 quadrillion Btu.

Hydroelectricity is well established in North America. In 1992, the region accounted for 26 percent (579 billion kilowatthours) of total world hydroelectricity consumption [2, p. 30]. The bulk of hydroelectricity in the region is attributed to Canada and the United States: Canada consumed 284 billion kilowatthours in 1992 and the United States 271 billion kilowatthours. In contrast, Mexico's hydroelectric consumption amounted to only 24 billion kilowatthours.

Geothermal and other renewable resources (including wind, solar, and biomass) have also been more extensively developed in North America than in other parts of the world. While the region consumed only about 15 billion kilowatthours of renewables other than hydroelectricity in 1992, that was 41 percent of the total world consumption of such resources [3]. The United States and Mexico are the major consumers of these "other" renewable resources, consuming 10 and 5 billion kilowatthours, respectively, in 1992.

\section{Canada}

\section{Hydroelectricity}

Since the 1970s, Canada has pursued extensive development of hydroelectric power. Hydroelectricity ensures Canada a secure source of energy for its consumers. Nearly two-thirds of the homes in the province of Quebec are all-electric, and most of their electricity supply is provided by hydropower [4, p. 72]. This energy resource allows Canada to generate electricity without greenhouse gas emissions and to maintain an important export commodity.

The development of hydroelectricity has been accompanied by fast-paced development of electricity-intensive industries. The 1979 startup of the Hydro-Quebec generating substation, Radisson, was followed by the introduction of several aluminum and magnesium smelters along the St. Lawrence River Valley, which require the energy equivalent of an entire large-scale hydroelectric complex to meet their electricity demands [4, p. 73].

All of the Canadian provinces, with the exception of Prince Edward Island, generate some hydroelectricity. The largest provincial generator of hydroelectricity is Quebec, and utilities in four other provinces generated more than 15 gigawatthours hydroelectricity each in 1991. Five of the ten provinces (and the Yukon and 
Northwest Territories) generated over 70 percent of their 1991 electricity supplies from hydropower (Table 22).

Many provincial utilities have plans for future hydroelectric development. In Newfoundland and Labrador, two hydroelectric generating stations are expected to be completed by 2006-Gull Island (2,264 megawatts) and Muskrat Falls (824 megawatts) [5, p. 40]. Manitoba Hydro expects to complete the 352-megawatt Wukswatim hydroelectric plant by 2000 [5, p. 41] and the 1,290-megawatt Conawapa station in 2008. Manitoba has dams, diversions, and altered flows on the Churchill and Nelson Rivers and wants to develop the Gods, Hayes, and Seal Rivers as well. During the 20052010 time frame, British Columbia Hydro plans to develop hydroelectric projects including the Waneta Expansion, Keenleyside, and Peace Site C [5, p. 42]. Although Ontario Hydro's excess capacity is expected to last for another 25 years because of lower-thananticipated domestic demand, plans have been made to refurbish several older hydroelectric power plants between 2005 and 2007.

Quebec Province has the most extensive hydroelectric development. The provincial utility, Hydro Quebec, is the second largest provider of electricity in Canada, with a generating capacity of 27 gigawatts, and 96 percent of that generating capacity is hydroelectric. The utility is committed to completing the 290-megawatt Laforge 2 plant by 1996 and the 880-megawatt Sainte Marguerite project by 2002 [6, p. B1]. The utility also has government approval to build a 485-megawatt hydroelectric facility on the Eastman River.
Development of Hydro Quebec's first large hydroelectric system - the James Bay River Project-began in 1972 [7, p. 130]. The project originally consisted of two phases. The first power plant of phase 1, the La Grande River project, was completed in 1982. It is the largest underground generating station in the world. Three others have since been commissioned, and work has begun on four others. When finished, the project will consist of 30 major dams and 500 separate dikes [4, p. 67]. The second phase, James Bay II, first proposed in 1975 , included a proposal to dam the Grande Rivière de la Baleine (the Great Whale River). Plans for the 3-gigawatt "Great Whale Project" were suspended on November 18, 1994, as a result of continuing environmental concerns and a substantial decline in the projected demand for electricity in North America [8, p. A8].

Hydro Quebec projects 1.8-percent annual growth in electricity demand over the next two decades, representing a total growth of 525 to 600 megawatts per year $[4$, p. $73 ; 9$, p. 12]. Overall, Canada has projected a 1.5percent annual growth rate for electricity demand between 1990 and 2020 [5, p. 38]. Annual electricity sales in Quebec increased on average by 7 percent per year between 1983 and 1989, but the growth rate has fallen to 1.4 percent annually since then [9, p. 12]. Complicating the utility's supply and demand picture are plans for an aggressive demand-side management program to reduce Quebec's energy demand by 5.4 percent by 2000 [9, p. 12]. Hydro Quebec projects that energy conservation measures could reduce demand by 3 gigawatts by 2010 [9, p. 12].

Table 22. Electricity Generation in Canada by Province, 1991

\begin{tabular}{|c|c|c|c|}
\hline Province & $\begin{array}{l}\text { Total Generation } \\
\text { (Gigawatthours) }\end{array}$ & \multicolumn{2}{|c|}{ Hydroelectric Generation } \\
\hline$\ldots \ldots \ldots \ldots \ldots \ldots \ldots \ldots \ldots$ & 121,455 & 117,040 & 96 \\
\hline British Columbia $\ldots \ldots \ldots \ldots \ldots \ldots \ldots \ldots \ldots$ & 48,633 & 47,880 & 98 \\
\hline Newfoundland and Labrador $\ldots \ldots \ldots \ldots \ldots$ & 35,640 & 34,107 & 96 \\
\hline$\ldots \ldots \ldots \ldots \ldots \ldots \ldots \ldots \ldots$ & 134,894 & 33,937 & 25 \\
\hline Saskatchewan $\ldots \ldots \ldots \ldots \ldots \ldots \ldots$ & 13,176 & 4,213 & 32 \\
\hline New Brunswick $\ldots \ldots \ldots \ldots \ldots \ldots \ldots \ldots$ & 14,999 & 2,935 & 20 \\
\hline 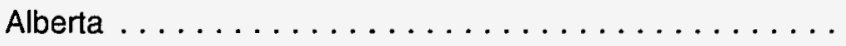 & 40,961 & 2,020 & 5 \\
\hline Nova Scotia . . . . . . . . . . . . . . . . & 9,016 & 1,030 & 11 \\
\hline Yukon .......... & 461 & 405 & 88 \\
\hline
\end{tabular}

Source: National Energy Board of Canada, Canadian Energy: Supply and Demand 1990-2010 (Calgary, Alberta: Minister of Public Works and Government Services Canada, December 1994), pp. 5-9 - 5-25. 


\section{Hydroelectric Trade and Canada}

One important function of hydropower in Canada is its use as an export commodity to the United States. Since the 1970s, many of Canada's utilities have found themselves with a substantial surplus of hydroelectricity [10, p. 84-5]. Firm long-term electricity exports have been established from Manitoba to Minnesota and from Quebec to New York and Vermont [10, p. 76]. Interruptible exports have been established from Ontario to New York, Michigan, and Ohio and from Alberta and British Columbia to the U.S. Northwest and California [10, p. 85]. In 1993, Quebec's electricity exports to the United States amounted to about $\$ 385$ million. While coal- and nuclear-generated electricity contribute to the exports, a substantial amount is supplied by hydropower.

The Canadian utility Hydro Quebec has a stated goal to export 3.5 gigawatts of electricity a year to markets in the northeastern United States by 2003. However, a recent environmental impact statement analysis prepared by Hydro Quebec suggests that the export market will probably reach only 1.5 gigawatts by 2005 [9, p. 12]. Hydro Quebec provides electricity to consumers in New York and New England (especially, Massachusetts, New Hampshire, and Vermont), as well as various Canadian residents and commercial and industrial concerns. In the future, the utility would like to penetrate the electricity markets of Japan and Europe by producing and exporting (by tanker) electricity-based hydrogen, should that prove technologically and economically feasible [11, pp. 1517].

Contracts in place with customers in the northeastern United States presently draw off 6 percent of the installed hydroelectric capacity of Quebec province [9, p. 73]. In recent years, however, it has become more difficult for Canadian utilities to arrange electric power export contracts with the United States. In
1992, the New York Power Authority (NYPA) canceled an important contract to purchase an additional gigawatt from Hydro Quebec's grid, worth about $\$ 13$ billion [12, p. 15], mostly because of slumping energy demand caused by demand-side management, energy conservation, and a recession in the United States. Pressure from the Cree Indians and various international environmental groups probably contributed to the cancellation.

In March 1994, the NYPA opposed a 20-year, $\$ 5$ billion contract with Hydro Quebec, citing lack of demand for power in New York, high prices, and unresolved environmental concerns in Canada [12, p. 14]. The agreement between NYPA and Hydro Quebec would have provided for the transmission through the NYPA power grid of 780 megawatts of electricity every summer between 1999 and 2018 from Hydro Quebec's facilities to those of New York City's Consolidated Edison (Con Ed), and would have required New York to buy 3 billion kilowatthours of power per year from Quebec [12, p. 15]. In the revised contract agreement, Hydro Quebec will supply 800 megawatts of peak capacity at a rate of 1.5 billion kilowatthours annually, and Con Ed is no longer required to buy the power [13, p. 8].

Beyond the dealings with various New York entities, Hydro Quebec has been faced with additional U.S. controversies related to hydroelectricity. For instance, uncler pressure from environmentalists, both Dartmouth College (Hanover, New Hampshire) and Tufts University (Medford, Massachusetts) have divested their bond holdings in Hydro Quebec-worth a combined $\$ 8$ million [12, p. 15]. In Massachusetts, moreover, support is growing to introduce a bill in the State legislature that would apply State environmental laws to any power projects involved in supplying the State with electricity.

\section{Other Renewable Sources}

Beyond hydroelectricity, only modest development of renewable resources has occurred in Canada. In fact, in 1992 Canada consumed less that 30 million kilowatthours of the other renewable resources [3], compared with 15 billion kilowatthours consumed by the remainder of North America.

Within the past decade, some progress has been made in the development of Canadian wind resources. The

first Canadian wind farm was built in 1987 in Cambridge Bay (Northwest Territories) [14, p. 12]. More recently, a second 25-tower wind farm in Alberta was constructed in December 1993 as a joint effort between the Canadian company Wind Power, Inc., and U.S. Windpower [14, p. 12]. A neighboring $\$ 15$ million (Canadian dollars), 27-tower Alberta project-the PeKun-Nee wind farm-was expected to begin operation in 1994. The Pe-Kun-Nee wind farm is expected to supply almost 10 megawatts to the Alberta Province electric power grid [14, p. 12]. 
In an effort to encourage further development of wind power in Canada, the Alberta Energy Resources Conservation Board in 1984 devised a scheme whereby private wind power producers would channel excess electricity to the provincial power grid and draw equivalent amounts back, as needed [14, p. 12]. This gave the wind power producers a steady flow of electricity, even when the wind towers could not generate electricity because of calm weather. In 1988, the Small Power Research and Development Act was passed. The legislation acknowledged a formal role for wind power by giving renewable energy producers the right to contribute 125 megawatts to the 7,200-megawatt Alberta Interconnected System.

\section{Mexico}

In 1989, the installed electric capacity mix in Mexico included 32 percent from hydroelectricity and 3 percent from geothermal energy [15, p. 24]. Efforts to develop other renewable resources in Mexico include a World Bank plan to finance wind projects [16, p. 99], as well as the installation of photovoltaic technology throughout the most rural parts of the country.

Geothermal power has been developed in Mexico to the point that the Comision Federal de Electricidad (CFEMexico's government-owned electric utility) sells 70 megawatts of electricity generated at geothermal fields near Mexicali to Southern California Edison. This contract, signed in 1986, marked the first international sale of geothermal energy in North America [17, p. 51].

The United Nations Conference on Environment and Development (UNCED) has assisted in the implementation of photovoltaic programs in Mexico, which have resulted in the installation of photovoltaic technology in 60,000 Mexican villages, accounting for the greatest share of U.S. exports of photovoltaic equipment [18, p. 34].

\section{United States}

Consumption of hydroelectricity and other renewables is expected to increase by 2 percent per year in the United States between 1990 and 2010, and much of the growth will be in renewables other than hydroelectricity. Hydropower is expected to grow by only 0.6 percent through the end of the projection period [1, p. 94]. In May 1994, the U.S. Supreme Court held that States may impose conditions on hydroelectric operations, such as minimum stream flow requirements, as part of their authority under the Clean Water Act of 1977 [1, p. 32]. This ruling could limit hydroelectric generation at both existing and proposed projects as States ask the Federal
Energy Regulatory Commission to impose license conditions requiring operators to release water through spillways instead of through turbines.

Wind is expected to be the fastest-growing renewable energy source in the United States, at 13.2 percent annually through 2010 . This strong growth is attributed to technological improvements, higher prices for competing fuels, increased capacity needs, and environmental externality costs associated with conventional fossil-fired generating stations [1, p. 32]. Wind farms in California have a capacity of 1,500 megawatts and produce about 1.5 percent of the entire State's electricity $[19$, p. 41]. Combined, the three California wind farms generate enough power to meet the residential energy needs of a city the size of San Francisco. More than 16,000 wind turbines have been installed between the mountains east of San Francisco and Los Angeles, providing electricity-through a power grid-to over half a million homes [20, pp. 28-29].

Development of geothermal energy sources is limited geographically to the western United States, where about 1.5 gigawatts of new capacity is expected by 2010. Most solar development is limited to the Southwest, where growth of between 5 and 10 megawatts is projected through the end of the century [1, pp. 32-33].

\section{Central and South America}

In Central and South America, consumption of hydroelectricity and other renewable resources is expected to reach just over 4 quadrillion Btu by 2010 in the Reference Case (Table A7). The projected growth is less than 1 quadrillion Btu, mainly because hydroelectric resources in the region have already been extensively developed.

In Central and South America, hydroelectricity is the second largest contributor to the energy supply of the region (exceeding natural gas, coal, and nuclear power). In fact, 27 percent of all primary energy consumed in the region is hydroelectricity [2, pp. 118-124]. The development potential for hydroelectricity is greatest in Brazil, Colombia, Venezuela, and Argentina, which have strategic policies to increase the already significant share of total electricity output provided by hydropower.

Before 2000, Brazil expects to complete the expansion of two major hydroelectric plants, including the Itaipu station (a joint effort with Paraguay) which is already the largest hydroelectric dam project in the world [21, pp. 140-141]. The project's two plants will have a combined capacity of 20,000 megawatts. At present, 96 per- 
cent of Brazil's electricity is generated from its rivers . [22, p. 62].

\section{Asia}

Asia is projected to experience fast-paced growth in consumption of hydroelectricity and other renewable resources. In non-OECD Asia, consumption of these resources is expected to more than double between 1990 and 2010, from 3 quadrillion Btu to 8 quadrillion Btu (Table A7). In particular, China's consumption of renewable resources in 2010 is expected to be more than three times its 1990 level. Most of the increase in renewables consumption in non-OECD Asia is attributable to hydroelectricity. In Japan, however, geothermal energy is the major component of an increase from 1 quadrillion Btu of consumption in 1990 to 2 quadrillion Btu in 2010.

Several hydroelectric power projects are currently under development throughout the non-OECD countries of Asia. China, in particular, has large hydroelectric development potential-by some estimates, more than 350 gigawatts [23, p. 168]-although much of the potential capacity is located away from populated, urban areas. A large portion of the current hydroelectric plants are very small scale. About 60 percent of the 2,000 counties in China have their own small-scale hydro schemes, and more than half are dependent on hydropower for electricity.

Many of the new hydroelectric projects planned in China are large scale. The Three Gorges Project, a \$20 billion, 18-gigawatt project, has been approved [23, p. 168]. While the Three Gorges Project would contribute substantially to meeting China's electricity needs, the project is very expensive, and it is no longer clear that it can be completed before 2010, as planned [23, p. 168].

Wind power development is also planned in China. Whereas in 1992 China had only about 15 megawatts of generating capacity from wind power, official government plans call for 1 gigawatt by 2000 [23, p. 168]. The high costs associated with importing the necessary technology may, however, be prohibitive to such development.

Several countries in the non-OECD Asia regionincluding Indonesia, Malaysia, Nepal, the Philippines, and Pakistan-are at various stages in developing hydroelectric facilities. The major constraint for these relatively poor nations appears to be in securing finances for development, although another difficulty is the potential impact on local populations and the environment. Wind and solar projects are-with financing from the World Bank-also planned for India and Indonesia [16, p. 99]. In some island nations, such as Indonesia and Malaysia, hydroelectric development is possible, but primarily on sparsely populated islands where additional power is not needed [21, p. 104].

Appropriate natural conditions are prerequisite to developing geothermal power, and even then the potential output is limited so long as geothermal steam and naturally occurring geothermal hot water are the only sources that can be tapped economically. Japan, for one, has benefitted from an abundance of geothermal energy; and-beginning in 1973 with the start of the Arab oil embargo-the Japanese government has continued to invest in geothermal development [24, p. 42]. Current plans are to double the present installed capacity of 270 megawatts in Japan within the next few years.

\section{OE:CD Europe}

In OECD Europe, consumption of hydroelectricity and other renewables is expected to grow to 6.2 quadrillion Btu in 2010 in the Reference Case (Table A7). Hydroelectric development in OECD Europe is well established in the countries where conditions are suitable. Three countries-Norway, Sweden, and Franceaccount for one-half of the region's hydroelectric consumption [2, p. 123]. The most favorable sites in those countries have already been developed, and the potential for future expansion is limited.

Greece has fairly ambitious plans for hydroelectric development. Nine hydropower projects currently operate there, with a combined installed capacity of about 2 gigawatts [25]. Three more plants are currently under construction, scheduled to begin operation between 1996 and 1999, and there are plans for five additional plants [25, pp. 40-42].

Between 1982 and 1992, the supply of energy from wind power grew from 37 megawatts to 1,000 megawatts in the European Community (EC) [26, p. 81]. The EC currently expects to install more than 3,000 megawatts of new wind energy capacity by 2000 [19, p. 45], and by 2005 the EC hopes to have 8 gigawatts of wind capacity, supplying 1 percent of its total electricity [27, p. 94]. Germany, the Netherlands, and Denmark boast the world's largest wind development programs [28, p. 586]. Large wind projects are also planned for Italy, Spain, and the United Kingdom [29, p. 37].

Denmark currently has the most substantial wind power program in the world, generating half of all the 
EC's wind-developed electricity [19, p. 45]. In 1990, wind power supplied 2 percent of Denmark's power needs [30], and by 2000 the country hopes to generate 10 percent of its electricity from wind power.

Eight of the 19 wind farms in the United Kingdom are installed in Wales, making that country's share of wind power capacity second only to Denmark's worldwide $[31$, p. 60]. Two more wind farms are currently under construction in Wales, and another 20 are planned. The Netherlands hopes to have 1,000 megawatts of wind capacity by 2000 [30], and Germany hopes to have between 100 and 150 megawatts by 2000 .

\section{Eastern Europe/Former Soviet Union}

Further development of hydroelectricity in the EE/FSU region seems unlikely at the present time. There is an increasing recognition that hydroelectric projects are accompanied by environmental costs, which must be considered along with the energy benefits [23, p. 214]. Although there is substantial hydroelectric capacity in the former Yugoslavia, civil war there has diminished its use [21, pp. 127-128]. When the region attains political stability, electricity supply from hydropower may well return to previous levels [23, p. 214].

There have been some efforts to develop wind power in the FSU. In 1992, the American company, U.S. Windpower, formed a partnership with Krimenergo, a Ukrainian utility, to build a 500-megawatt wind farm on the Crimean peninsula [27, p. 94].

\section{Remainder of the World}

In Africa, almost two-thirds of the hydroelectricity produced in 1989 could be attributed to only five countries: Egypt, Ghana, Mozambique, Zaire, and Zambia [21, p. 93]. Development projects for Africa include joint development by Zaire and Zambia along the Zambezi River. Kenya expects to add 140 megawatts of capacity by 1995 [21, p. 93]. Physical conditions in the Middle East make hydroelectric development and current supply insignificant. Operable hydroelectric capacity in that region currently exists only in Iran, Iraq, Syria, and Lebanon [21, p. 149].

\section{References}

1. Energy Information Administration. Annual Energy Outlook 1995. DOE/EIA-0383(95). Washington, DC, January 1995.
2. Energy Information Administration. International Energy Annual 1992. DOE/EIA-0219(92). Washington, DC, January 1994.

3. Energy Information Administration, Office of Energy Markets and End Use. International Statistics Database.

4. J.G. Mitchell. "James Bay: Where Two Worlds Collide." National Geographic, Vol. 184, No. 5A. November 1993. pp. 66-75.

5. Energy and Fiscal Analysis Division, Natural Resources Canada. Canada's Energy Outlook, 1992-2020. Ottawa, Ontario: Minister of Supply and Services Canada, September 1993.

6. A. Derfel. "Power to the People: Can Quebec Survive Without Great Whale?" The Montreal Gazette. November 26, 1994. p. B1.

7. "Native Garden of the North." Sierra, Vol. 79, No. 2. March 1994. p. 130.

8. C. Trueheart. "Canada Drops Giant Hydroelectric Project." The Houston Chronicle. November 21, 1994. p. A8.

9. J. Simpson. "Hydro-Quebec's Whale of a Project Could Be a Tad Much." Public Utilities Fortnightly, Vol. 131, No. 22. December 1, 1993. p. 12.

10. National Energy Board. Canadian Energy: Supply and Demand, 1990-2010. Ottawa, Ontario: Minister of Supply and Services Canada, June 1991.

11. M.L. Barker and D. Soyez. "Think Locally, Act Globally?: The Transnationalization of Canadian Resource-Use Conflicts." Environment, Vol. 36, No. 5. June 1994. pp. 12-36.

12. B. Came. "Cowboy Capitalist: An American Energy Czar Confounds Quebec Authorities." MacLean's, Vol. 107, No. 18. May 2, 1994. pp. 14-16.

13. J. Simpson. "Hydro-Quebec, Con Ed Agree to New Contract." Public Utilities Fortnightly, Vol. 132, No. 8. April 15, 1994. p. 8.

14. A. Tulley. "The Age of Wind Power Dawns in Alberta." Canadian Geographic, Vol. 114, No. 2. March/ April 1994. p. 12.

15. I. Rodriguez and D. Wolcott. "Growth Through Conservation: DSM in Mexico." Public Utilities Fortnightly, Vol. 131, No. 15. August 1, 1993. pp. 23-26.

16. "The Quixotic Technology." The Economist, Vol. 325, No. 7785. November 14, 1992. pp. 99-100. 
17. V. Budhraja. "Geothermal Energy Market in Southern California: Past, Present \& Future." Executive Speeches, Vol. 7, No. 4. February-March 1993. pp. 51-53.

18. "A Global View of Photovoltaics." Public Utilities Fortnightly, Vol. 131, No. 21. November 15, 1993. p. 34.

19. J.G. McGowan. "Tilting Toward Windmills." Technology Review, Vol. 95, No. 5. July 1993. pp. 39-46.

20. R.C. MacKenzie. "Alternative Energy: It's a Question of Cost." Canada and the World, Vol. 57, No. 5. January 1992. pp. 26-31.

21. International Energy Agency. Global Energy: The Changing Outlook. Paris, France, 1992.

22. "Brazilian Energy Policy: Pass the Rum." The Economist, Vol. 324, No. 7766. July 4, 1992. p. 62.

23. International Energy Agency. World Energy Outlook: 1994 Edition. Paris, France, 1994.

24. H. Hase. "Geothermal Programs Contributing to the Earth's Environment." Japan 21st, Vol. 38, No. 3. March 1993. pp. 42-43.
25. E.C. Kalkani, J. Stefanakos, and N.J. Moutafis. "Hydro Development of Greece's Acheloos and Aliakmon Rivers." Power Engineering, Vol. 98, No. 7. July 1994. pp. 40-43.

26. "Renewable Energy: Clean Profits." The Economist, Vol. 38, No. 7830. September 25, 1993. p. 81.

27. M.B. Regan. "The Sun Shines Brighter on Alternative Energy." Business Week, No. 3345. November 8, 1993. pp. $94-95$.

28. R.D. Griffin. "Alternative Energy." $C Q$ Researcher, Vol. 2, No. 25. July 10, 1992. pp. 575-595.

29. H.L. Chum, R. Overend, and J.A. Phillips. "The Great Energy Harvest." The Futurist, Vol. 27, No. 3. May-June 1993. pp. 34-40.

30. S. Stern. "The Way the Wind Blows." International Management, Vol. 49, No. 2. March 1994. pp. 33-35.

31. "A New Way To Rape the Countryside." The Economist, Vol. 330, No. 7847. January 22, 1994. p. 60. 


\section{Electricity}

\section{Electricity is the fastest growing form of end-use energy worldwide. Continued growth in electricity demand is projected, accompanied by increasing competition among suppliers in many countries.}

Through the end of the 1990s and the first decade of the 21st century, as the world becomes increasingly dependent on electricity, the electric power industry is expected to undergo significant change. Three major trends characterize the industry on a worldwide basis: growth in demand; changes in structure, creating more competition and greater incentives for efficiency; and shifts in the generation fuel mix, favoring natural gas and renewables. These trends-with some variationscan already be seen in most regions of the world.

Electricity is expected to remain the fastest growing form of end-use energy worldwide through 2010 [1, p. 19]. Indeed, about 42 percent of the increase in total worldwide fuel consumption projected for the 19922010 period is expected to be for electricity generation (see Tables 24 and A1). From 1990 to 1992, electricity consumption grew more than six times as rapidly as total end-use energy consumption ( 3.9 percent and 0.6 percent, respectively). The growth in electricity consumption worldwide is expected to continue at an annual rate of 2.0 percent from 1990 through 2010 (Figure 47), varying on a regional basis. A study per-

Figure 47. World Electricity Consumption, 1970-2010

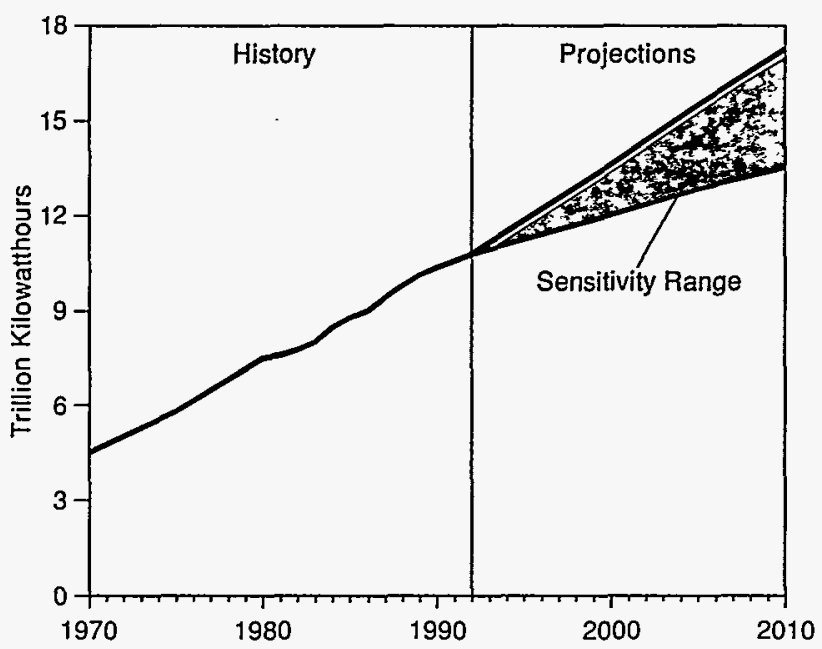

Sources: History: 1970-1979: Energy Information Administration (EIA), Office of Energy Markets and End Use, International Statistics Database. 1980-1992: EIA, International Energy Annual 1992, DOE/ ElA-0219(92) (Washington, DC, January 1994). Projections: ElA, World Energy Projection System (1995). formed in 1993 found 453 projects being developed around the world to build and operate electric generating plants and transmission systems [2, p. D1]. In general, growth in OECD countries, where electricity markets are becoming saturated, will be slower than in non-OECD countries, where a large amount of demand remains unsatisfied. In 1990, most of the OECD population was served by electricity, while in the developing countries about 50 percent of the population still did not have access to electricity.

Non-OECD countries, with 75 percent of the world's population, consume less than 40 percent of the overall world electricity output. On a per capita basis, the divergence between the OECD and non-OECD regions is significant. Average electricity generation per person in developing countries is 660 kilowatthours, compared with 10,500 kilowatthours in the United States and about 6,000 kilowatthours in OECD Europe and Japan (Table 23) [3, p. 51]. Thus, there is great potential for growth as non-OECD countries seek to expand the availability of electricity to their populations, especially in those countries showing signs of sustainable economic expansion. Industry estimates place the size of the power market in the developing world in the next 20 years "as high as one trillion dollars" [2, p. D1].

Electricity demand growth in OECD countries in general will be moderate, at an annual rate of 1.7 percent between 1990 and 2010, with Japan and Other OECD (Australia, New Zealand, and U.S. Territories) experiencing the greatest increases within OECD (Table A8). The non-OECD country group will experience the largest increase in electricity consumption, at an estimated annual rate of 2.3 percent for the period. The world's slowest growth is expected in the EE/FSU region, at an annual rate of only 0.5 percent. Within the non-OECD Asia group, China and the Other Asia region, which includes several countries with expanding economies (such as South Korea, Indonesia, Singapore, Thailand, Philippines, and Taiwan), will experience the strongest increase in electricity consumption between 1990 and 2010. China, in particular, is expected to almost triple its electricity consumption. In the Other Asia region, consumption will jump from 706 to about 1,324 billion kilowatthours over the 1990-2010 period. Despite the impressive growth rates in the non-OECD 
Table 23. Electricity Generation per Capita by Region, 1990

\begin{tabular}{|c|c|}
\hline Region/Country & $\begin{array}{c}\text { Kilowatthours } \\
\text { per Person }\end{array}$ \\
\hline United States . . . . . . . . . . & 10,500 \\
\hline Japan . . . . . . . . . . . . & 6,000 \\
\hline Western Europe $\ldots \ldots \ldots \ldots \ldots$ & 6,000 \\
\hline France ........... & 5,500 \\
\hline Taiwan ................. & 4,455 \\
\hline Spain . . . . . . . . . . . . . & 3,000 \\
\hline South Korea & 2,687 \\
\hline Argentina $\ldots \ldots \ldots \ldots \ldots$ & 1,579 \\
\hline Central and South America ...... & 1,034 \\
\hline China . . . . . . . . & 550 \\
\hline India $\ldots \ldots \ldots \ldots \ldots \ldots$ & 340 \\
\hline Indonesia . . . . . . . . . . . & 275 \\
\hline
\end{tabular}

Sources: "World Energy Outlook," Economic Review, Vol. 22, No. 3 (March 1991), p. 51; S. Meyers, N. Goldman, N. Martin, and R. Friedman, "Prospects for the Power Sector in Nine Developing Countries," Energy Policy (November 1993), pp. 1123-1132.

country group, however, their share of overall world electricity consumption will remain disproportionately small-relative to their share of the world populationincreasing from about 39 percent in 1990 to only a little more than 42 percent in 2010.

With growing dependence on electricity, dramatic changes are expected in the electric power industry around the globe. Many countries are currently working to create more competitive market environments for electricity sales, with incentives to ensure greater efficiency. These efforts are producing significant changes in three key areas: regulation, structure, and ownership. In addition, changes in each of these areas often are associated with movement toward greater internationalization of the electric power industry, as countries become net exporters or net importers of electricity. At the same time, private companies compete in global markets for opportunities in power generation, equipment supply, and services.

Regulatory changes often lead to the elimination of monopolies and reduction of governmental intervention in the electric power industry. Reforms include the reduction of price controls and tariff restrictions and the elimination of subsidies. Structural changes are characterized by the division of the industry into its three major functions-generation, transmission, and distribution-and a commitment from governments to ensure that independent producers and other powerrelated enterprises will have full and fair participation in each of the functions. Ownership trends include an emphasis on privatization and commercialization to attract private capital from foreign and domestic sources.

Many non-OECD countries facing high electricity demand growth favor privatizing their electric power sectors and opening their markets to foreign firms. This approach can free up large amounts of public capital, which can be used instead for social programs. In addition, private ownership allows managerial accountability, market efficiency, and better customer service while reducing government deficits and international debt [4, p. 211].

Changes in the fuel mix for world electricity generation are also expected in the next 15 years. For example, natural gas use is expected to increase as several new gas generating plants being planned or under construction start operation (Table 24 and Figure 48): the natural gas share of total electricity generation is expected to increase from 13 percent in 1990 to about 17 percent in 2010. Conversely, nuclear generation will slow down as the number of nuclear reactors retired surpasses the number of new units being commissioned. As a result, the nuclear share of power generation is expected to decline from its highest point of 17 percent in 1992 to 14 percent in 2010. Coal will remain the primary fuel for generating electricity with a share of more than 35 percent; however, both the coal and oil shares will decline as natural gas and other fuels (such as hydroelectricity and renewables) penetrate the market.

Figure 48. World Electricity Consumption by Generating Fuel Type, 1990 and 2010

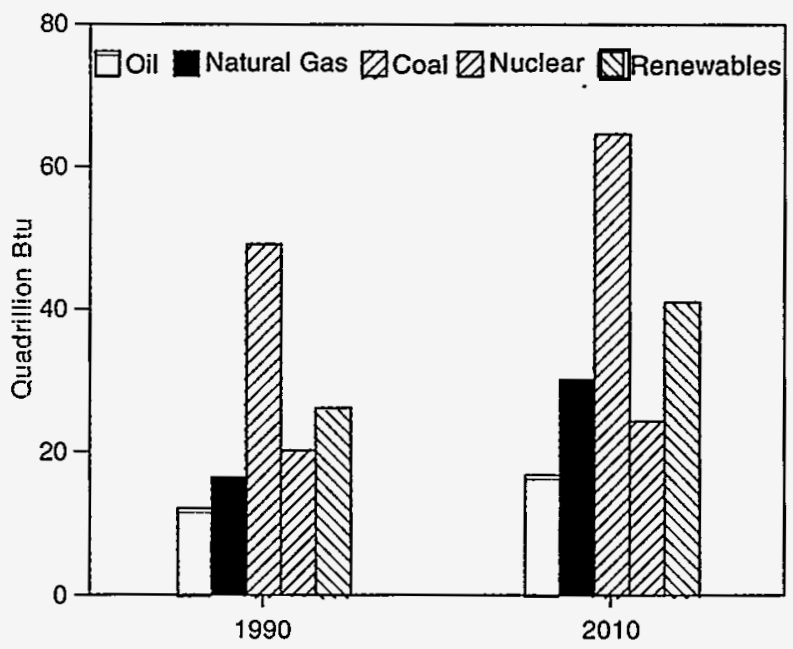

Sources: History: Energy Information Administration (EIA), International Energy Annual 1992, DOE/EIA-0219(92) (Washington, DC, January 1994). Projections: EIA, World Energy Projection System (1995). 
Table 24. World Energy Consumption for Electricity Generation by Region and Fuel, 1990-2010 (Quadrillion Btu)

\begin{tabular}{|c|c|c|c|c|c|}
\hline \multirow[b]{2}{*}{ Region/Fuel } & \multicolumn{2}{|c|}{ History } & \multicolumn{3}{|c|}{ Projections } \\
\hline & 1990 & 1992 & 2000 & 2005 & 2010 \\
\hline OECD & 71.7 & 73.9 & 85.2 & 91.2 & 97.3 \\
\hline Oil $\ldots \ldots \ldots \ldots \ldots \ldots \ldots \ldots \ldots$ & 5.7 & 5.7 & 5.9 & 6.2 & 6.2 \\
\hline Natural Gas $\ldots \ldots \ldots \ldots \ldots \ldots \ldots$ & 6.0 & 6.4 & 10.1 & 12.5 & 15.0 \\
\hline Coal ...... & 28.0 & 28.3 & 30.6 & 31.9 & 33.4 \\
\hline Nuclear . . & 16.2 & 17.4 & 18.8 & 19.2 & 18.7 \\
\hline Renewables & 15.7 & 16.1 & 19.8 & 21.5 & 24.0 \\
\hline Non-OECD $\ldots \ldots \ldots \ldots \ldots \ldots \ldots$ & 52.6 & 51.0 & 64.4 & 72.3 & 79.7 \\
\hline Oil $\ldots \ldots \ldots \ldots \ldots \ldots \ldots \ldots \ldots$ & 6.4 & 6.2 & 8.6 & 9.6 & 10.6 \\
\hline Natural Gas . & 10.4 & 10.3 & 12.3 & 13.9 & 15.1 \\
\hline Coal ...... & 21.2 & 19.7 & 25.7 & 28.5 & 31.3 \\
\hline Nuclear & 4.1 & 4.0 & 5.0 & 5.4 & 5.6 \\
\hline Renewables & 10.5 & 10.7 & 12.8 & 14.9 & 17.1 \\
\hline Total World ................... & 124.2 & 124.9 & 149.7 & 163.6 & 177.0 \\
\hline Oil $\ldots \ldots \ldots \ldots \ldots \ldots \ldots \ldots \ldots$ & 12.1 & 11.9 & 14.5 & 15.8 & 16.8 \\
\hline Natural Gas & 16.4 & 16.8 & 22.5 & 26.4 & 30.2 \\
\hline Coal ...... & 49.2 & 48.0 & 56.3 & 60.4 & 64.6 \\
\hline Nuclear ... & 20.3 & 21.4 & 23.7 & 24.6 & 24.4 \\
\hline$\ldots \ldots \ldots \ldots \ldots \ldots \ldots$ & 26.2 & 26.8 & 32.6 & 36.4 & 41.1 \\
\hline
\end{tabular}

Note: $\mathrm{OECD}=$ Organization for Economic Cooperation and Development.

Sources: History: Energy Information Administration (EIA), International Energy Annual 1992, DOE/EIA-0219(92) (Washington, DC, January 1994). Projections: International Energy Agency (IEA), Energy Balances of OECD Countries, 1991-1992 (Paris, France, 1994); IEA, Energy Statistics and Balances of Non-OECD Countries, 1991-1992 (Paris, France, 1994); and EIA, World Energy Projection System (1995).

\section{OECD North America}

Electricity demand in North America is expected to grow moderately from 1990 to 2010 -by about 1.4 percent per year, slightly less than the 2.0-percent annual growth rate for worldwide electricity consumption (Table A8). Mexico leads the growth in electricity demand in North America at 2.6 percent per year, and Canada follows at 1.7 percent per year. U.S. electricity demand is expected to increase less rapidly, at 1.3 percent annually.

Conflicting forces are affecting the growth of North American electricity demand. Demand is stimulated by the introduction of new technologies that consume electricity, and increased use of equipment powered by electricity is expected in both the work and home environments as North Americans rely increasingly on personal computers, laser printers, security systems, and facsimile machines. In Canada, electricity demand in the industrial sector is expected to grow more rapidly over the next 20 years than it has over the past two decades, with electricity's share of total energy use increasing from 27 percent in 1991 to 31 percent by 2010 [5, p. 16]. This growth reflects the increasing use of electrical processes in the pulp and paper, smelting and refining, and iron and steel industries. On the other hand, the higher efficiency of new equipment and technologies, brought about by consumer purchases of energy-efficient replacement appliances and greater utility investment in demand-side management programs, will tend to moderate the growth in electricity demand over the forecast horizon in both Canada and the United States.

North America is expected to rely increasingly on natural gas to generate electricity, although coal will remain the dominant fuel source. The natural gas share of total fuel use for electricity production is expected to rise from 8 percent to over 10 percent, while coal's share declines from 44 percent in 1990 to 40 percent in 2010. The use of natural gas has expanded in North America largely because of its favorable environmental qualities and because combined-cycle gas generation technologies provide efficient generating units with relatively short leadtimes for construction. Low prices 


\section{Restructuring of the Electric Power Industry in North America}

Change in the North American electric power industry was set in motion in the mid-1970s, primarily by economic factors. Rising fossil fuel prices induced by oil price shocks caused electricity prices to increase substantially, and high levels of inflation raised the cost of constructing and financing power generation facilities. Moreover, many major construction projects, especially nuclear power plants, experienced large cost overruns due to design problems and changing environmental and safety requirements.

\section{United States}

The United States reacted to the changing economics of energy production by enacting the Public Utility Regulatory Policies Act of 1978 (PURPA, Public Law 96-617), which encourages efficient use of fossil fuels in electricity production through cogeneration and the use of renewable resources. The key provision of PURPA requires utilities to purchase power from facilities meeting criteria outlined in the legislation at the utility's incremental cost of production. In 1986, the Federal Energy Regulatory Commission (FERC) was proactive in introducing more competition into electricity supply by issuing a rule on competitive bidding for new generation supply. Many States developed bidding procedures that encouraged participation by nonutilities and placed greater emphasis on demand-side conservation options.

Despite the success of PURPA, some analysts contend that it did not go far enough. The Energy Policy Act of 1992 (EPACT, Public Law 102-486) created a new category of power producers-exempt wholesale generators (EWGs). EPACT eliminated a major barrier to the construction of new non-rate-based power plants by utility-affiliated and nonaffiliated power producers competing in the electricity market. In order to facilitate the marketing of EWG power, transmission provisions were included in the law, giving FERC the authority to order utilities to provide access to customers through their transmission systems.

Because of the many technical and site-specific issues involved in transmission service, FERC has encouraged self-regulation of transmission systems, acting as an arbitrator of last resort when the industry is unable to resolve disputes. FERC has issued a series of rules promoting the formation of Regional Transmission Groups (RTGs), whose mission is to coordinate and facilitate transmission planning and operation for utilities and nonutilities.
A number of States have taken aggressive steps toward opening both wholesale and retail markets, while others are waiting to see how the restructured industry unfolds. For example, a bill to allow retail competition in New Mexico was voted down by the State legislature in 1993. Conversely, in Michigan, regulators have decided to test open retail competition in a small experiment, allowing the customers of the State's two largest utilities to purchase power from other utilities or nonutilities for up to 60 megawatts of capacity. In California, reform proposals have been more radical. Starting on January 1, 1996, the State's largest industrial customers may no longer be required to purchase electricity from their local utilities. Medium-sized and small businesses will be allowed to follow suit in 1998 and 1999, respectively, and residential customers in 2002. Thus, by 2002, all electricity customers in California may be able to purchase power in competitive markets. Debate continues on the proper implementation of these proposals, including the need for coordination and system support for the competitive markets.

\section{Canada}

The Canadian electric power industry is also undergoing change in reaction to external forces and the restructuring of the U.S. market. At the request of Natural Resources Canada, the Canadian National Energy Board (NEB) conducted a study to determine how the government could eliminate barriers to interprovincial trade and promote cooperation. Subsequently, the NEB released reports that outlined the potential for increased cooperation between utilities with regard to transmission access and wheeling and estimated significant potential savings from increased interprovincial and international transactions. The NEB developed four options to encourage cooperation among utilities and initiated public comment and evaluation. Most involved agreed that increased wheeling and cooperation among utilities would be beneficial, but preferences as to the manner in which it would be promoted and regulated differed. In general, those entities without access to external markets tended to favor federally mandated solutions to disputes that might arise, while those with transmission access tended to favor voluntary access and wheeling policies [6, pp. 10-14].

In reaction to the changing U.S. market, the NEB also granted authorization for "unconventional" applications to export power. Ontario Hydro was given 


\section{Restructuring of the Electric Power Industry in North America (Continued)}

permission to trade with purchasers in the United States not directly connected with their system, and B.C. Hydro and Manitoba Hydro were authorized to enter short-term transactions (up to 3 years) without prior NEB approval [6, p. 19]. The Canadian government is also examining guidelines for utilities in Canada regarding memberships in RTGs. In the United States, the FERC issued a rule of reciprocity under which RTG members have the right to wheel power over other members in the RTG lines but, in turn, must provide the same service. The Canadian government is considering rules for Canadian utilities to participate in these groups, subject to similar performance requirements.

\section{Mexico}

The Mexican electric power industry is also changing the way it operates by allowing private companies to invest in the electricity sector. Historically, private companies could only produce electricity for their own use, with surplus power sold to the public utility, CFE. Recently, new legislation-“"Regulations of the Public Service of Electric Law"-has been passed, which allows private companies to invest in power production facilities and to import power as long as the power is supplied as a private service to the private sector. Any surplus power from projects must be sold to the CFE. resulting from abundant supplies of natural gas in Canada and Mexico also contribute to the expected increase in gas consumption. Consumption of other fuels-predominantly hydroelectric-also increases significantly over the projection period, at a 2.4-percent annual rate (Table A7), as the development of hydroelectric potential in Canada, particularly in Labrador and Manitoba, continues. Increasing hydroelectric capability may also result in a reduction of coal-fired generation in Manitoba and its neighboring Canadian provinces [5, p. 33].

\section{North American Free Trade Agreement}

Energy trade between the North American countries is dominated by natural gas and petroleum. Electricity accounts for only a minor portion of the overall North American energy trade, and it has historically been fairly open between the nations. The North American Free Trade Agreement (NAFTA) is expected to have little impact on international electricity trade, except as it affects the pricing of international transactions and provides slightly improved access to California markets by utilities in western Canada. However, the NAFTA provisions regarding government procurement and investment may offer significant opportunities for U.S. and Canadian investment in the Mexican electricity market. NAFTA allows foreign investors to compete on equal footing with domestic bidders for government procurement opportunities, including equipment and other supplies for the Mexican National electric utility, the Comision Federal de Electricidad (CFE-The Federal Electricity Commission). NAFTA also allows foreign ownership of certain electricity generating facilities in Mexico, which could represent a significant opportunity for Canadian and U.S. investors, particular- ly in light of the expected strong growth in their demand.

\section{OECD Europe}

Compared with other regions, OECD Europe is expected to experience low electricity growth through 2010. The power industry in this region is expected to expand at a moderate annual rate of 1.8 percent over the 1990-2010 period. The International Energy Agency expects this growth to keep pace with projections of Europe's GDP growth. Expansion of the region's generating capacity will result mainly from the construction of new natural gas plants and further penetration of renewable technologies [1, p. 48].

Some countries in OECD Europe have taken steps to introduce elements of competition in their power industries. Others are in the process of formulating regulatory changes that will ensure a move toward privatization and an overall restructuring of the electricity markets. These countries, including the United Kingdom, the Netherlands, Norway, Sweden, Finland, and Portugal, are for the most part still in a transitional phase that prevents evaluation of the final impacts of such changes. Nevertheless, "preliminary indications are that competitive markets for electricity generation and supply, with proper regulation of competition and natural monopoly elements, can work efficiently" [7, p. 49].

The United Kingdom privatized its power industry in 1990. Nuclear electricity is the only generating activity that remains in the public sector. The country has two major private generators, twelve regional electricity companies that supply and distribute the electricity, 
and a national company that operates the transmission system and coordinates power dispatch. Independent power producers are developing several projects around the country, primarily natural gas plants.

In the Netherlands, electricity production and distribution activities were disaggregated in 1989 with the implementation of a new electricity law. The restructuring included vertical disintegration and an overall reorganization of the industry, promoting diverse environmental and conservation programs. Four public electric companies now compete to satisfy the country's electricity demand, and distributors have the freedom to buy power from any producer or to generate their own electricity. The Netherlands imports about 15 percent of its electricity from France and Germany; imports from Norway are expected at the beginning of the next decade, when a new undersea cable between the two countries will be completed.

Norway deregulated its electricity markets in 1991 and 1992. The 1990 Norwegian Energy Act, which became effective in January 1991, calls for increased competition in the production and sale of electricity. Statkraft, the state power company, was divided into two independent government-owned companies: a production company (Statkraft SF) and a grid company (Statnett SF). Initial impacts of the industry restructuring include the reduction of industrial rates and stabilization of residential rates.

Sweden is moving toward competitive generating and distribution markets at local, regional, and national networks by 1995 . Under legislation still being debated, Swedish consumers would be allowed to buy power from any producer, primarily on the basis of prices. The legislation also would open regional monopolies to competition by 1995 [7, p. 51].

Other European countries considering the restructuring of power industries are Italy, Ireland, and France. Italy is preparing for the privatization of its state-owned electric utility, ENEL, but the plans do not include the splitting of ENEL into separate companies. ENEL will retain monopoly rights over transmission and distribution activities. The Irish government has decided to restructure the state-owned Electricity Supply Board into five business units: power generation, national grid, customer service, commercial enterprises, and business services. In France, the reforms being considered for the electricity sector include the removal of monopoly rights of the state-owned electric utility, Electricité de France (EDF), over generation and import and export activities. However, EDF will retain control over the management and planning of transmission and distribution systems.

In 1993, the Commission of the European Communities ${ }^{9}$ presented a draft proposal that calls for negotiations to ensure access to the electricity and gas grids within the European common market. The proposal favors "access to grids by large consumers and distributors, the institution of competitive bidding for development of new generating capacity and accounting separation of generation, transmission, and distribution" [7, p. 53].

Another trend of growing importance in Europe is international electricity trade among OECD countries. France, the leading exporter of electricity in the OECD, is likely to remain a net exporter. The International Energy Agency (IEA) expects France to export about 16 percent of its net electricity generation by 2010 [7, p. 239]. Gross electricity exports by France in 1993 totaled 61.4 terawatthours $[8$, p. 6]. Some countries, such as Italy and the Netherlands, are expected to continue to be net importers of electricity through 2010. An example of successful electricity trading and integration among OECD Europe countries is the joint power system of Norway, Sweden, Finland, and Denmark. By allowing the balancing of surpluses and shortages across country borders, these countries realize savings in installed capacity without compromising reliability.

Environmental concerns limit capacity expansion plans in some countries. In particular, the siting of new facilities is becoming increasingly difficult. In response to the Global Climate Change initiative, some European countries-including Denmark, Finland, the Netherlands, Norway, and Sweden-have enacted carbon taxes. The taxes range from $\$ 3$ per metric ton of carbon emitted in the Netherlands, to about $\$ 166$ per metric ton in Sweden and Norway [9, pp. 6-9]. Denmark imposed carbon taxes in the residential sector in May 1992 and in the industrial and commercial sectors in January 1993 [7, p. 67]. Both Sweden and Norway established carbon taxes in 1991. In Sweden the carbon tax system was modified in 1993 to differentiate the treatment of different fuels and economic sectors.

\section{OECD Pacific}

Demand for electricity is expected to grow faster in the OECD Pacific region than in Europe and North Ameri$\mathrm{Ca}$, in association with the economic growth anticipated for the region. Expected changes in the fuel mix used for generation are similar to those expected in other OECD countries, with emphasis on natural gas and

\footnotetext{
'The European Communities include Belgium, Denmark, France, Germany, Greece, Ireland, Italy, Luxembourg, the Netherlands, Portugal, Spain, and the United Kingdom.
} 
coal. However, the OECD Pacific region will experience an increase-instead of a reduction-in the use of nuclear power. All nuclear capacity expansion will take place in Japan, where about 25 percent of electricity generation is from nuclear power.

The Japanese government plans to expand its nuclear capacity to allow a nuclear generation share of 40 percent by 2010 . Overall electricity consumption is expected to grow at an annual rate of 2.9 percent between 1990 and 2010. Although the Japanese government has not initiated reforms in the electric power industry, deregulation is expected in the future. This process may include the promotion of nonutility generation for sale to major utilities.

The Australian government is committed to a completely competitive power market by 1999, through a reform process that was initiated in 1991, encompassing the development of independent interstate transmission networks and competitive generation. In the state of Victoria, the integrated utility has already been divided into separate generation, transmission, and distribution companies. Coal is the predominant fuel used for electricity generation in the country, and its share will continue growing through 2010.

New Zealand started reforms in the electricity sector in 1987 with the creation of the Electricity Corporation of New Zealand (ECNZ). The industry is still in a transitional state as the government continues industry deregulation. The ECNZ generates most of the country's electricity, which is sold to 40 power companies at the wholesale level [10, p. 24]. A transmission corporation was created in 1993, and monopolies in local distribution and retailing have been eliminated. Hydropower is expected to keep its dominant share of generation at over 70 percent, but the government is recognizing the need to diversify.

\section{Non-OECD ,}

Overall electricity demand is expected to remain strong in non-OECD countries through 2010 as a result of continued economic development characterized by aggressive industrialization and urbanization programs in some developing countries (Table A8). Electricity consumption is expected to grow by 57 percent in the 19902010 period, at an annual rate of 2.3 percent. Leading the growth in electricity demand are China and the countries of the Pacific Rim region. Strong electricity consumption is also expected in Other Asia countries, such as India and Pakistan, and in Central and South America.
Changes in the structure of power industries in several non-OECD countries are expected as governments implement reforms to attract foreign and international private investments. Secure electricity supplies are essential to the continued economic development being experienced in these countries, and large amounts of capital will be needed to expand their generating capacity. International finance organizations, such as the World Bank, are promoting commercialization and privatization of the power industry to reduce the inefficiency and mismanagement that have characterized a number of state-owned power utilities in the past. The World Bank, the largest single investor in electric power in developing countries, in 1993 summarized its guiding principles for power sector loans as follows [11, p. 14]:

- Transparent regulatory processes that are clearly independent of power suppliers and that avoid government interference in day-to-day power company operations

- Financing of power service imports to improve efficiency

- Commercialization and corporatization of, and private sector participation in, the power sectors of developing countries

- Lending for electric power projects in countries with a clear commitment to improving power sector performance.

\section{Eastern Europe/Former Soviet Union}

The EE/FSU region will experience relatively slow growth in electricity consumption over the forecast period. Total electricity consumption is expected to increase by only 10 percent, at an annual rate of 0.5 percent, between 1990 and 2010. Given the recent political upheaval in the region, it is difficult to estimate the prospects for electricity. What seems clear is that the electric power sector needs complete upgrading to ensure acceptable environmental, reliability, and efficiency levels [9, pp. 6-9]. In particular, the nuclear reactors operating in the region must be improved to meet international standards, or they will face the risk of permanent retirement. Pressures to operate even unsafe reactors persist, because the ability to develop alternative generation capacity is limited by a shortage of capital.

Reduced economic growth rates and, in particular, the slowdown of production in the industrial sector have caused a reduction in EE/FSU electricity consumption since 1990. Declines are expected to continue through 
1995, but thereafter the beginning of economic recovery is anticipated in the context of significant policy reforms favoring the freeing up of market regulation. Reform of energy prices has begun in most of the region. As electricity prices are adjusted to reflect the true production costs, more efficient use of electricity is anticipated. In that context, electricity consumption in residential and commercial sectors is expected to rise while the industrial share declines.

The traditional electricity industries in this region are vertically integrated monopolies controlled by central governments, but reforms have started in some countries with respect to structure, ownership, and regulation. Examples of countries where reform has been initiated include Poland, Russia, and the Czech Republic. Reforms are considered necessary by some nations to ensure the availability of foreign funds needed to upgrade and expand the power industry. For example, Poland has disaggregated its power sector, and independent generation companies now compete, even though the power generation market is still subject to a variety of regulatory requirements. Also, independent transmission and distribution companies have been created that operate separately from generating companies. Privatization of electricity generation and distribution companies is also being considered, although the government plans to maintain 51 percent ownership of the transmission grid. Russia began a decentralization program in 1993 that will allow 75 percent of its generating capacity to be under the responsibility of regional power companies and their regulatory bodies. The Czech Republic is privatizing its national generating and transmission company, and plans have been made to privatize regional distribution companies [12, p. 12].

Changes in the electricity production fuel mix in the $\mathrm{EE} / \mathrm{FSU}$ region include increases in the use of natural gas and nuclear power, with the natural gas share projected to grow from 29 percent in 1990 to almost 36 percent in 2010. Natural gas is favored by some countries in the region because of its expected availability and the relatively low investment associated with combinedcycle gas turbine plants. Nuclear electricity generation is also expected to grow in the region, although the nuclear share of total generation will remain at about 13 percent. The governments of Ukraine, Romania, and the Czech Republic have plans to expand nuclear capacity. Conversely, Bulgaria has decided to shut down some of the nuclear generating units because of safety and environmental concerns.

\section{China}

Electricity consumption in China is expected to more than double over the forecast period, from 562 billion kilowatthours in 1990 to 1,593 billion kilowatthours in 2010. China's annual growth rate in electricity consumption during the $1990-2010$ period is estimated at 5.4 percent, which is higher than the already robust growth rate of 2.3 percent per year projected for the non-OECD country group. Demand for electricity in China has been growing rapidly for several decades, and electricity generation grew by almost 10 percent per year between 1985 and 1992. Yet, even that dramatic increase was not enough to avert serious electricity shortages that created frequent blackouts and kept factories closed for long periods of time in some parts of the country. The current shortage in electricity supply has been estimated at around 10 to 15 gigawatts of peak capacity [1, p. 188].

The Chinese government has aggressively expanded electric generating capacity in the past few years. China's 1992 generating capacity was 165 gigawatts, almost 70 percent coal-fired, about 35 percent of which was built between 1988 and 1992. China is now the world's fourth largest power consumer, even though per capita consumption is only 5 percent of that in the United States and only 13 percent of that in Hong Kong [13, p. 17]. The government's target for the rest of the decade is to add at least 15 gigawatts of generating capacity annually [14, p. 30]. Plans include expansion of traditional power supplies, including coal and hydroelectricity, and the development of nuclear capacity. In 1994, 906 megawatts of new nuclear capacity came online, and the Chinese government signed an agreement to buy two new 700-megawatt nuclear units from Canada [15, p. 1].

Opportunities for international energy investments in China have resulted from the government's decision to open the power sector to foreign investment. Several joint ventures have already been established for the construction of electric generating units, and the nation's legal framework is being modified to allow the possibility of full foreign ownership of power plants [16, pp. 12-13]. In at least one project (the Shajiao B power plant in Guangdon), the concept of buildoperate-transfer (BOT) is being tested. In this case, a foreign company is allowed to finance, build, and then operate the project for a specified period of time before turning it over to the local authority [17, p. 63]. 


\section{Other Asia}

Within the non-OECD country group, the Other Asia subgroup has the highest projected electricity growth-an increase of 88 percent between 1990 and 2010, at an annual rate of 3.2 percent. This subgroup includes a number of countries in the Pacific Rim region with rapidly growing economies and strong industrialization programs, notably, South Korea, Taiwan, Thailand, the Philippines, and Indonesia. Most of these countries have experienced tremendous growth in electricity consumption, and their governments generally have aggressive plans to continue expanding their generating capacities. Some have embraced reforms in their power sectors, allowing privatization, deregulation, and independent producer participation.

Thailand has defined criteria for the privatization of its power industry in the past few years and is allowing the creation of wholly owned power generating subsidiaries. Three projects designated for privatization are Rayong (1,200-megawatt combined-cycle), Khanom (600-megawatt combined-cycle), and Aoi Pai (1,400megawatt coal-fired). In addition, the government endorses the purchasing of electricity from individual private power generators by the Electricity Generating Authority of Thailand (EGAT) [18, p. 2]. The possibility of developing nuclear power in Thailand is presently under consideration.

Electricity generation grew by about 15.3 percent annually in Indonesia during the 1980-1990 period, among the highest growth rates in the region, reflecting the accelerated expansion of capacity. Nevertheless, the country's per capita generation in 1990 remained among the world lowest at 275 kilowatthours per person, and only 33 percent of the population had access to electricity [19, pp. 1123-1132]. Although coal's share is expected to grow in Indonesia's power generating mix, capacity expansion plans also include the construction of nuclear power plants. The government of Indonesia has implemented reforms in the power sector aimed at attracting private investments, and as a result, privately funded projects are being negotiated for the construction of new power plants.

South Korea and Taiwan are the leaders in industrialization and electricity generation in the Other Asia region. Per capita generation of electricity in South Korea, at 2,687 kilowatthours, and Taiwan, at 4,455 kilowatthours, far exceeds the levels in most non-OECD countries (Table 23). Both South Korea and Taiwan have had substantial growth in nuclear power generation over the past few years, and South Korea has the largest installed nuclear capacity among the non-OECD countries. The use of nuclear power, as well as natural gas, is expected to continue growing in these two nations through 2010 . With relatively healthy financial situations in their power sectors, South Korea and Taiwan will be able to attract the private investments necessary for continued capacity expansion.

In the Philippines, the power sector is characterized by continuous outages due to insufficient electricity supply. The situation has worsened since 1986 with the retirement of a 600-megawatt nuclear reactor. Geothermal resources are available, and the government hopes to add 1,600 megawatts of geothermal capacity between 1991 and 2000. The Philippines plans to rely heavily on private investment through $\mathrm{BOT}$ agreements. By the end of 1993, a total of 27 contracts had been awarded to the power sector for the construction of power plants [14, p. 30]. The Philippines is planning to restructure and to privatize the National Power Corporation, the country's main state-owned utility [18, p. 2].

Pakistan and India, also in the Other Asia subgroup, are also expected to experience accelerated growth in electricity demand. Pakistan is benefitting from World Bank financing through a BOT scheme to develop the Hab River oil-fired power project, which will include four 323-megawatt units. The Pakistani government is encouraging more BOT agreements, both for new power projects and for some of the thermal power stations managed by the country's major utility [18, p. 2].

India's power sector is moving toward allowing 100 percent foreign ownership of generating plants. About 5 percent of the country's power comes from four private companies, which are reporting profits. The other 95 percent is from 18 state-owned utilities, most of which operate at a loss. It is expected that the private sector will add about 24 gigawatts of new capacity in India by the year 2000 [18, p. 2]. The Indian government is counting on independent producers to expand electricity capacity to meet targets set by the end of the century. Annual growth in electricity demand in India is expected to average about 8 to 10 percent for the rest of the 1990s [20, p. v].

\section{Central and South America}

The Central and South America region represents one of the most promising markets for electricity investment worldwide. The region's generation is primarily from hydroelectric plants. Coinciding with a trend away from authoritarian regimes toward democracies, the countries in the region have experienced a trend in the electric power industry shifting from nationalization 
schemes implemented in the 1960 s to privatization and more competitive structures, similar to those taking place in the markets in OECD countries in the 1990s. Reform mechanisms include full participation of the private sector, elimination of subsidies and price controls, and reduction of tariffs and import restrictions.

In the 1950s, only 30 percent of the population of Central and South America was served by electricity. The region experienced strong economic growth during the 1960s and 1970s, which was matched by rapid expansion of the electrical infrastructure. Today, approximately 70 percent of the population has access to electricity as a result of large investments in generation, transmission, and distribution facilities in the 1960s and 1970s. During the 1980s, however, most of the nations in the region were affected by economic slowdowns, which led to a lack of capacity additions and deterioration of the existing infrastructure. By 1988, per capita electricity consumption in Central and South America was estimated at about 1,034 kilowatthours, compared with about 10,500 kilowatthours in the United States, 5,500 kilowatthours in France, and 3,000 kilowatthours in Spain [21, p. PR4]. Additional capacity is needed to accommodate an expected 2.2-percent annual population growth rate, to satisfy increasing per capita consumption, and to expand the percentage of the population served by electricity. Furthermore, many facilities will need upgrading within the next few years. Electricity consumption in the region is expected to grow at an annual rate of 2.6 percent for the 1990-2010 period.

The scarcity of capital that characterizes nations in this region and the pressing need for investment in the power sector are forcing governments to consider domestic and international private financing. This is one of the most desirable mechanisms considered by governments to ensure that increasing electricity demand will be met and that economic development will continue. In the next 10 years, financing will be needed to add an estimated 66 gigawatts of additional generating capacity in Central and South Americaincluding more than 57 gigawatts of new capacity needed in the 11 countries of South America, at an estimated cost of $\$ 61.6$ billion [22, p. 11]. Overall estimates of capital needed in the Central and South American power sector vary from $\$ 120$ to $\$ 150$ billion [21, p. PR4; 23, p. 12].

International finance institutions, such as the World Bank, the InterAmerican Development Bank, and the Japanese Export-Import Bank, will provide some of the capital needed for the power sector expansion. The rest may be covered by the private sector. The private power market in South America by 1999 has been estimated at about 21 gigawatts capacity, with Chile and Argentina representing almost 95 percent of the potential [22, p. 11].

Chile, Argentina, and Peru have followed the lead of the United Kingdom in restructuring their power industries, including the separation of the three most important industry activities-generation, transmission, and distribution. The restructuring is being followed by strong efforts to ensure competition and privatization [24, p. S18]. Chile, the leading country in the region's privatization process, adopted a progressive pricing mechanism during the $1980 \mathrm{~s}$, similar to the long-term - marginal cost pricing schemes implemented by some developed countries. A new tariff system allows market forces to determine location, construction type, and efficient operation of new power generating plants. Argentina follows a privatization program similar to the one developed by Chile. In addition, both countries have approved legislation to provide open access to power transmission lines.

Although Brazil is considering privatization of its electric power sector, the necessary steps to initiate the process have not been taken. Nevertheless, the Brazilian government is developing a variety of alternative energy projects that imply collaboration and agreements with the private sector. These projects include generating plants powered with biomass, sugar cane residues, solar, and wind. About 97 percent of Brazil's electricity is generated by hydroelectric power plants. Government officials recognize that diversification of the electricity production is an important issue and that private investment will be necessary [25, p. 11].

\section{References}

1. International Energy Agency. World Energy Outlook: 1994 Edition. Paris, France, 1994.

2. T. Lippman. "An Electrifying Opportunity: U.S. Utilities Join Charge to Power International Markets." The Washington Post. April 20, 1994. p. D1.

3. "World Energy Outlook." Economic Review, Vol. 22, No. 3. March 1991. p. 51.

4. R. Skinner. "Economics and Financing of Future Power: Is There a Case for Nuclear?" Energy Study Review, Vol. 5, No. 3. 1993. pp. 211-224.

5. National Energy Board. Canadian Energy Supply and Demand 1993-2010. Appendix to the Technical Report. Calgary, Alberta, 1994. 
6. National Energy Board. Review of Inter-utility Trade in Electricity. Calgary, Alberta, January 1994.

7. International Energy Agency. Energy Policies of IEA Countries: 1993 Review. Paris, France, 1994.

8. V. Baum. "Growth in Asian Power Switches Fócus to Financing: Growing Electricity Demand in Asia." Petroleum Economist, Vol. 61, No. 2. February 1994. p. 6.

9. V. Baum. "Glowing in the Gloom." Petroleum Economist, Vol. 60, No. 2. February 1993. pp. 6-9.

10. M. Kennedy. "Electricity Is New Zealand's Power Hitter." Public Utilities Fortnightly, Vol. 131, No. 16. September 1, 1993. p. 24.

11. World Bank. The World Bank's Role in the Electric Power Sector: Policies for Effective Institutional, Regulatory, and Financial Reform. Washington, DC, 1993.

12. International Energy Agency. Electricity in European Economies in Transition. Paris, France, 1994. p. 12.

13. "Hopwell's Success in China Power." Privatization International. December 1993. p. 17.

14. F. Gray. "Asia Doubles Electricity Generating Capacity." Petroleum Economist, Vol. 60, No. 12. December 1993. p. 30.

15. "AEOCL Closes in on China Reactor Sale." The Energy Daily, Vol. 22, No. 215. November 9, 1994. p. 1.

16. C. Brogan. "Tantalizing Tarim To See Foreign Explorers." Petroleum Economist, Vol. 60, No. 4. April 1993. pp. 12-13.
17. C. Goldstein. "Charged Up: Foreign Firms Plan Chinese Power Ventures." Far Eastern Economic Review. April 15, 1993. p. 63.

18. F. Gray. "Survey of World Electricity." Financial Times. May 14, 1992. p. 2.

19. S. Meyers, N. Goldman, N. Martin, and R. Friedman. "Prospects for the Power Sector in Nine Developing Countries." Energy Policy. November 1993. pp. 1123-1132.

20. G. Doyle. "Survey of World Electricity." Financial Times. May 14, 1992. p. v.

21. E. Santos. "The Push To Privatize: Developing Essential Infrastructure in Latin America." Latin Finance, No. 44. January 1993. p. PR4.

22. "Study Sees 20,876-MW Private Power Potential in South America by 1999." Independent Power Report. July 31, 1992. p. 11.

23. R. Hunt, P. Moore, and L. Zeiger-Hatfield. "Changing Energy Policies in South America Create Opportunities for U.S. Suppliers and Investors." Business America, Vol. 114, No. 10. March 17, 1993. p. 12.

24. D. DePinto and R. McWhinney, Jr. "Conducting Business: Privatization of Peru's Electric Sector; Privatization in Latin America 1994." Latin Finance, No. 55. March 1994. p. S18.

25. "Looming Electricity Shortages Lead Brazil to Alternative Energy Sources." Environment Watch Latin America, Vol. 3, No. 12. December 1993. p. 11. 



\section{Appendix A World Energy Consumption and Carbon Emissions Tables}



Table A1. World Total Energy Consumption by Region and Fuel, 1990-2010 (Quadrillion Btu)

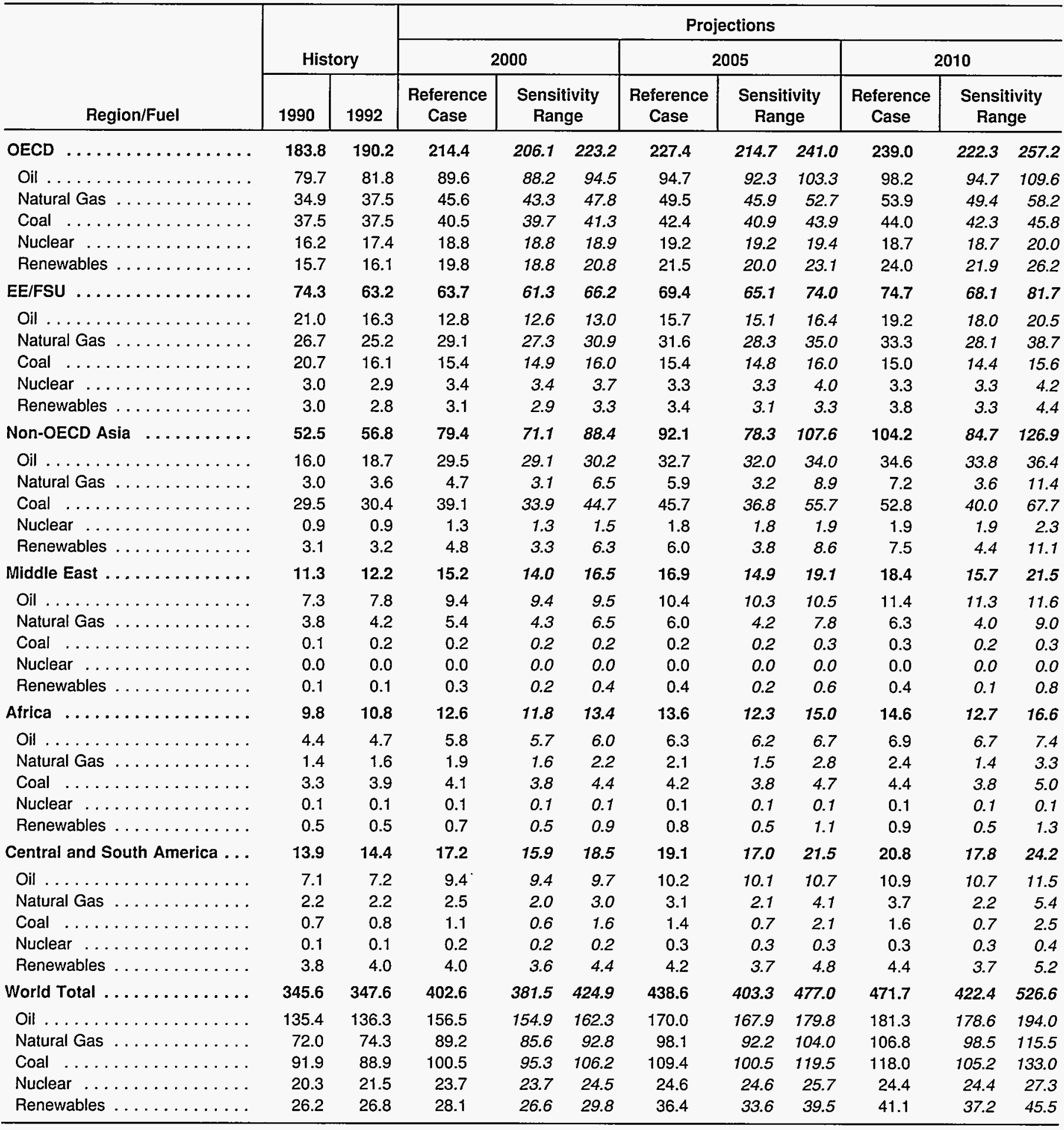

Notes: OECD = Organization for Economic Cooperation and Development. EE/FSU = Eastern Europe/Former Soviet Union. Energy totals include consumption of biofuels in the United States. All sensitivity ranges are derived independently and do not necessarily add to totals. Other totals may not equal sum of components due to independent rounding. The electricity portion of the national fuel consumption values consists of generation for domestic use plus an adjustment for electricity trade based on a fuel's share of total generation in the exporting country.

Sources: History: Energy Information Administration (ElA), International Energy Annual 1992, DOE/EIA-0219(92) (Washington, DC, January 1994). Projections: EIA, World Energy Projection System (1995). 
Table A2. World Total Energy Consumption by Region, 1990-2010 (Quadrillion Btu)

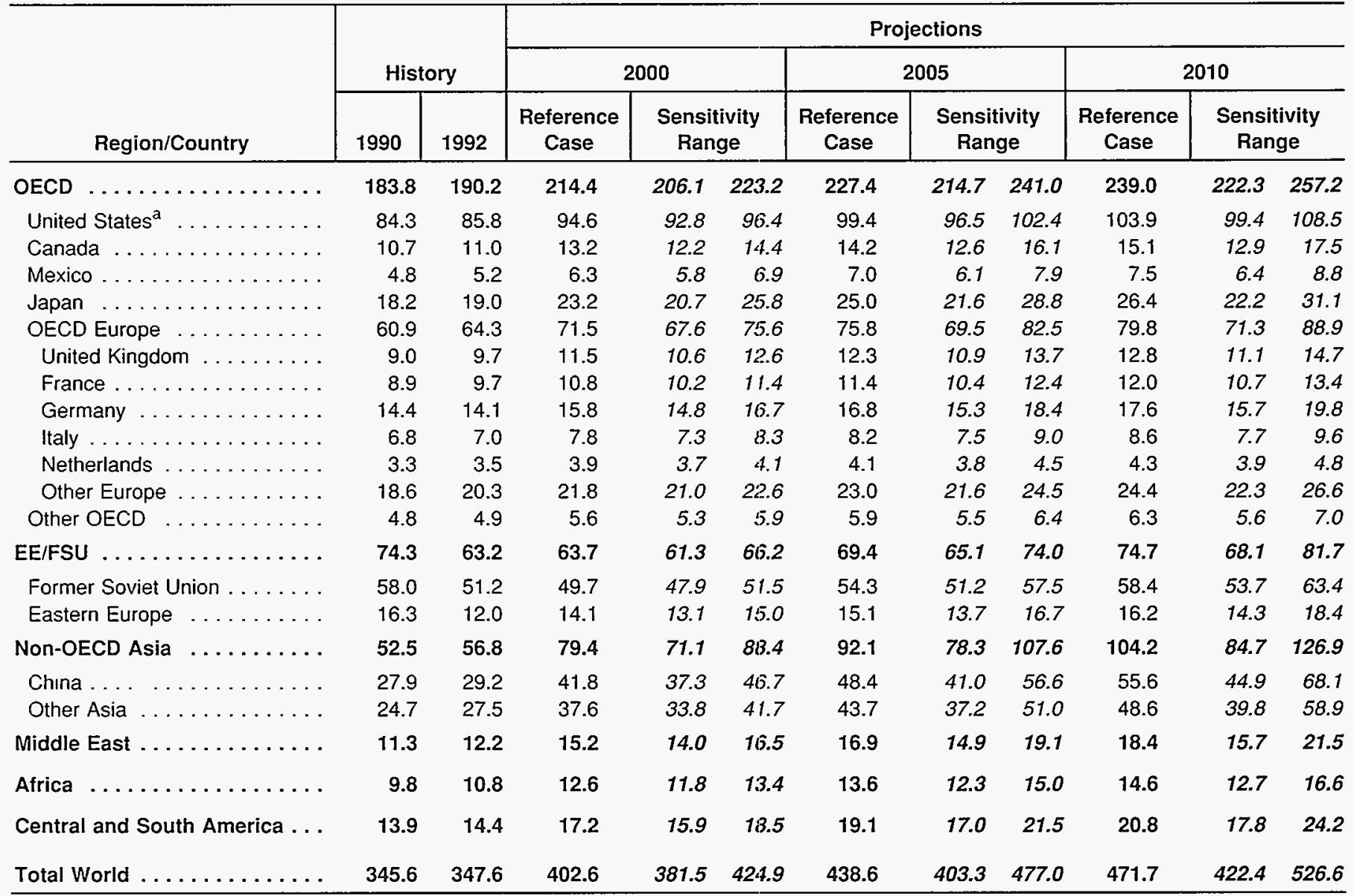

ancludes the 50 States and the District of Columbia. U.S. Territories are included in "Other OECD."

Notes: OECD = Organization for Economic Cooperation and Development. EE/FSU = Eastern Europe/Former Soviet Union. Energy totals include consumption of biofuels in the United States. All sensitivity ranges are derived independently and do not necessarily add to totals. Other totals may not equal sum of components due to independent rounding. The electricity portion of the national fuel consumption values consists of generation for domestic use plus an adjustment for electricity trade based on a fuel's share of total generation in the exporting country.

Sources: History: Energy Information Administration (EIA), International Energy Annual 1992, DOE/EIA-0219(92) (Washington, DC, January 1994). Projections: EIA, Annual Energy Outlook 1995, DOE/EIA-0383(95) (Washington, DC, January 1995), Table B1; and World Energy Projection System (1995). 
Table A3. World Total Oil Consumption by Region, 1990-2010 (Million Barrels per Day)

\begin{tabular}{|c|c|c|c|c|c|c|c|c|c|c|c|}
\hline \multirow[b]{2}{*}{ Region/Country } & & & \multicolumn{9}{|c|}{ Projections } \\
\hline & 1990 & 1992 & $\begin{array}{c}\text { Reference } \\
\text { Case }\end{array}$ & $\begin{array}{r}\text { Sensit } \\
\text { Ran }\end{array}$ & & $\begin{array}{c}\text { Reference } \\
\text { Case }\end{array}$ & $\begin{array}{r}\text { Sensit } \\
\text { Ran }\end{array}$ & iity & $\begin{array}{c}\text { Reference } \\
\text { Case }\end{array}$ & $\begin{array}{r}\text { Sensi } \\
\text { Ran }\end{array}$ & \\
\hline OECD $\ldots \ldots \ldots \ldots \ldots \ldots$ & 39.5 & 40.6 & 44.7 & 43.9 & 47.1 & 47.2 & 46.0 & 51.5 & 48.9 & 47.2 & 54.6 \\
\hline United States $^{\mathrm{a}} \ldots \ldots \ldots \ldots$ & 17.0 & 17.0 & 18.9 & 18.7 & 19.5 & 20.1 & 19.8 & 21.3 & 20.9 & 20.4 & 22.5 \\
\hline Japan $\ldots \ldots \ldots \ldots \ldots$ & 5.1 & 5.5 & 6.0 & 5.8 & 6.5 & 6.3 & 6.0 & 7.2 & 6.6 & 6.2 & 7.9 \\
\hline OECD Europe $\ldots \ldots \ldots \ldots$ & 12.9 & 13.6 & 14.3 & 14.1 & 15.3 & 15.0 & 14.5 & 16.4 & 15.4 & 14.8 & 17.2 \\
\hline United Kingdom . . . . . . . . & 1.8 & 1.8 & 1.9 & 1.9 & 2.0 & 2.0 & 1.9 & 2.2 & 2.0 & 2.0 & 2.3 \\
\hline France $\ldots \ldots \ldots \ldots$ & 1.8 & 1.9 & 2.0 & 2.0 & 2.2 & 2.1 & 2.1 & 2.3 & 2.2 & 2.1 & 2.4 \\
\hline Germany . & 2.7 & 2.8 & 3.0 & 2.9 & 3.2 & 3.1 & 3.0 & 3.4 & 3.2 & 3.1 & 3.6 \\
\hline EE/FSU $\ldots \ldots \ldots \ldots \ldots \ldots$ & 10.0 & 7.8 & 6.1 & 6.0 & 6.2 & 7.5 & 7.2 & 7.8 & 9.2 & 8.6 & 9.8 \\
\hline Former Soviet Union . . . . . . . & 8.4 & 6.7 & 4.7 & 4.6 & 4.7 & 5.9 & 5.8 & 6.2 & 7.5 & 7.1 & 8.0 \\
\hline Eastern Europe $\ldots \ldots \ldots \ldots$ & 1.6 & 1.1 & 1.4 & 1.4 & 1.5 & 1.6 & 1.5 & 1.6 & 1.7 & 1.5 & 1.8 \\
\hline Non-OECD Asia $\ldots \ldots \ldots \ldots$ & 7.6 & 8.8 & 14.0 & 13.8 & 14.3 & 15.5 & 15.2 & 16.1 & 16.4 & 16.0 & 17.3 \\
\hline China . . . . . . . . . . & 2.3 & 2.6 & 3.7 & 3.6 & 3.8 & 3.9 & 3.6 & 4.1 & 4.0 & 3.7 & 4.3 \\
\hline Other Asia $\ldots \ldots \ldots \ldots$ & 5.3 & 6.2 & 10.3 & 10.2 & 10.6 & 11.6 & 11.4 & 12.2 & 12.4 & 12.2 & 13.2 \\
\hline Middle East $\ldots \ldots \ldots \ldots \ldots$ & 3.5 & 3.7 & 4.5 & 4.5 & 4.5 & 5.0 & 4.9 & 5.0 & 5.4 & 5.4 & 5.6 \\
\hline Africa $\ldots \ldots \ldots \ldots \ldots \ldots$ & 2.1 & 2.2 & 2.8 & 2.7 & 2.9 & 3.1 & 3.0 & 3.2 & 3.3 & 3.2 & 3.6 \\
\hline Central and South America ... & 3.5 & 3.5 & 4.6 & 4.5 & 4.7 & 5.0 & 4.9 & 5.2 & 5.3 & 5.2 & 5.6 \\
\hline
\end{tabular}

ancludes the 50 States and the District of Columbia. U.S. Territories are included in "Other OECD."

Notes: OECD = Organization for Economic Cooperation and Development. EE/FSU = Eastern Europe/Former Soviet Union. All sensitivity ranges are derived independently and do not necessarily add to totals. Other totals may not equal sum of components due to independent rounding. The electricity portion of the national fuel consumption values consists of generation for domestic use plus an adjustment for electricity trade based on a fuel's share of total generation in the exporting country.

Sources: History: Energy Information Administration (EIA), International Energy Annual 1992, DOE/EIA-0219(92) (Washington, DC, January 1994). Projections: ElA, Annual Energy Outlook 1995, DOE/EIA-0383(95) (Washington, DC, January 1995), Table C20; and World Energy Projection System (1995). 
Table A4. World Total Natural Gas Consumption by Region, 1990-2010 (Trillion Cubic Feet)

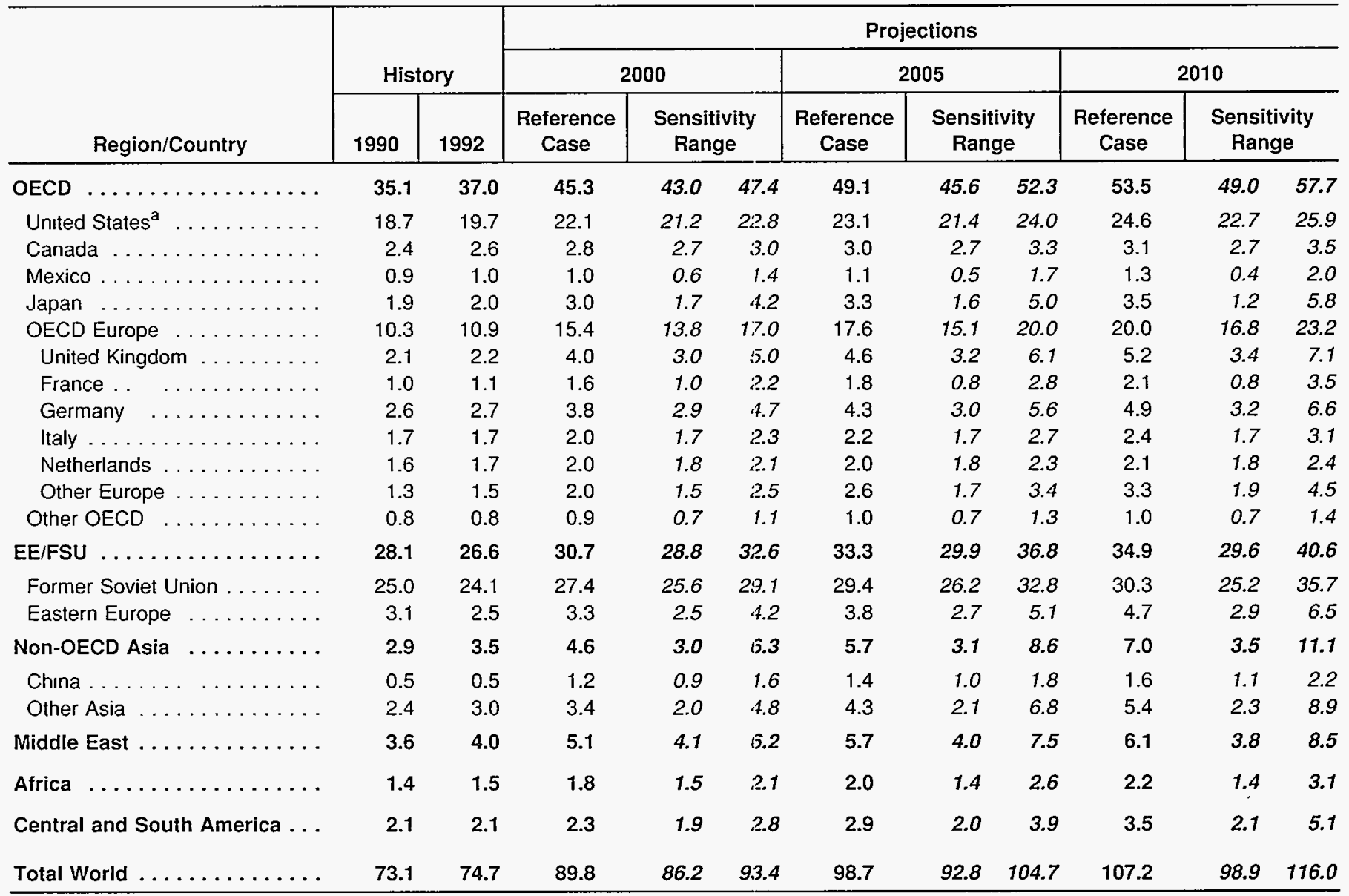

ancludes the 50 States and the District of Columbia. U.S. Territories are included in "Other OECD."

Notes: OECD = Organization for Economic Cooperation and Development. EE/FSU = Eastern Europe/Former Soviet Union. Range values for OECD Europe and the four regional totals are not equal to the sum of the component countries or country groups but consist of the base value adjusted by the quantity: the square root of the sum of the squared deviations of the respective component countries or country groups from their base value. Other totals may not equal sum of components due to independent rounding. The electricity portion of the national fuel consumption values consists of generation for domestic use plus an adjustment for electricity trade based on a fuel's share of total generation in the exporting country. To convert cubic feet to cubic meters, divide each number in the table by 35.315 .

Sources: History: Energy Information Administration (EIA), International Energy Annual 1992, DOE/EIA-0219(92) (Washington, DC, January 1994). Projections: EIA, Annual Energy Outlook 1995, DOE/EIA-0383(95) (Washington, DC, January 1995), Tables B13 and C13; and World Energy Projection System (1995). 
Table A5. World Total Coal Consumption by Region, 1990-2010 (Million Short Tons)

\begin{tabular}{|c|c|c|c|c|c|c|c|c|c|c|c|}
\hline \multirow[b]{2}{*}{ Region/Country } & & & \multicolumn{9}{|c|}{ Projections } \\
\hline & 1990 & 1992 & $\begin{array}{l}\text { Reference } \\
\text { Case }\end{array}$ & $\begin{array}{r}\text { Sensit } \\
\text { Rang }\end{array}$ & $\begin{array}{l}\text { ivity } \\
\text { ge }\end{array}$ & $\begin{array}{c}\text { Reference } \\
\text { Case }\end{array}$ & $\begin{array}{r}\text { Sensit } \\
\text { Ran }\end{array}$ & $\begin{array}{l}\text { ivity } \\
\text { ge }\end{array}$ & $\begin{array}{c}\text { Reference } \\
\text { Case }\end{array}$ & $\begin{array}{r}\text { Sensi } \\
\text { Ran }\end{array}$ & $\begin{array}{l}\text { ivity } \\
\text { ge }\end{array}$ \\
\hline OECD $\ldots \ldots \ldots \ldots \ldots \ldots$ & 2,124 & 2,006 & 2,163 & 2,118 & 2,205 & 2,163 & 2,084 & 2,238 & 2,342 & 2,249 & 2,436 \\
\hline United States $^{\mathrm{a}} \ldots \ldots \ldots \ldots$ & 895 & 892 & 954 & 943 & 962 & 992 & 976 & 1,004 & 1,039 & 1,010 & 1,078 \\
\hline Japan $\ldots \ldots \ldots \ldots \ldots$ & 125 & 125 & 158 & 124 & 192 & 178 & 115 & 238 & 179 & 112 & 244 \\
\hline OECD Europe $\ldots \ldots \ldots \ldots$ & 930 & 804 & 843 & 821 & 863 & 871 & 831 & 909 & 901 & 848 & 952 \\
\hline United Kingdom . . . . . . . & 110 & 119 & 119 & 118 & 120 & 116 & 113 & 119 & 116 & 113 & 119 \\
\hline France $\ldots \ldots \ldots \ldots \ldots$ & 39 & 37 & 33 & 29 & 37 & 32 & 25 & 39 & 29 & 19 & 39 \\
\hline Germany . . . . . . . . . . & 509 & 363 & 343 & 329 & 356 & 342 & 313 & 372 & 336 & 298 & 374 \\
\hline EE/FSU $\ldots \ldots \ldots \ldots \ldots$ & 1,271 & 1,130 & 1,090 & 1,051 & 1,127 & 1,090 & 1,049 & 1,130 & 1,057 & 1,011 & 1,101 \\
\hline Former Soviet Union . . . . . . . & 744 & 643 & 596 & 559 & 633 & 592 & 553 & 631 & 590 & 546 & 632 \\
\hline Eastern Europe $\ldots \ldots \ldots \ldots$ & 527 & 487 & 494 & 485 & 502 & 498 & 486 & 508 & 467 & 453 & 479 \\
\hline Non-OECD Asia $\ldots \ldots \ldots \ldots$ & 1,581 & 1,670 & 2,151 & 1,866 & 2,459 & 2,512 & 2,023 & 3,064 & 2,904 & 2,201 & 3,724 \\
\hline China $\ldots \ldots \ldots \ldots \ldots$ & 1,145 & 1,204 & 1,656 & 1,456 & 1,872 & 1,939 & 1,608 & 2,312 & 2,248 & 1,767 & 2,812 \\
\hline Other Asia . . . . . . . . & 436 & 466 & 495 & 407 & 588 & 574 & 411 & 753 & 656 & 429 & 914 \\
\hline Middle East $\ldots \ldots \ldots \ldots \ldots$ & 7 & 8 & 8 & 8 & 9 & 10 & 8 & 12 & 10 & 8 & 14 \\
\hline Africa $\ldots \ldots \ldots \ldots \ldots$ & 155 & 151 & 160 & 149 & 172 & 165 & 148 & 183 & 169 & 146 & 194 \\
\hline Central and South America ... & 33 & 37 & 48 & 28 & 69 & 60 & 30 & 92 & 69 & 31 & 109 \\
\hline
\end{tabular}

ancludes the $\mathbf{5 0}$ States and the District of Columbia. U.S. Territories are included in "Other OECD."

Notes: $\mathrm{OECD}=$ Organization for Economic Cooperation and Development. EE/FSU $=$ Eastern Europe/Former Soviet Union. Range values for OECD Europe and the four regional totals are not equal to the sum of the component countries or country groups but consist of the base value adjusted by the quantity: the square root of the sum of the squared deviations of the respective component countries or country groups from their base value. Other totals may not equal sum of components due to independent rounding. The electricity portion of the national fuel consumption values consists of generation for domestic use plus an adjustment for electricity trade based on a fuel's share of total generation in the exporting country. To convert short tons to metric tons, divide each number in the table by 1.102.

Sources: History: Energy Information Administration (EIA), International Energy Annual 1992, DOE/ElA-0219(92) (Washington, DC, January 1994). Projections: EIA, Annual Energy Outlook 1995, DOE/EIA-0383(95) (Washington, DC, January 1995), Table B16; and World Energy Projection System (1995). 
Table A6. World Net Nuclear Energy Consumption by Region, 1990-2010 (Billion Kilowatthours)

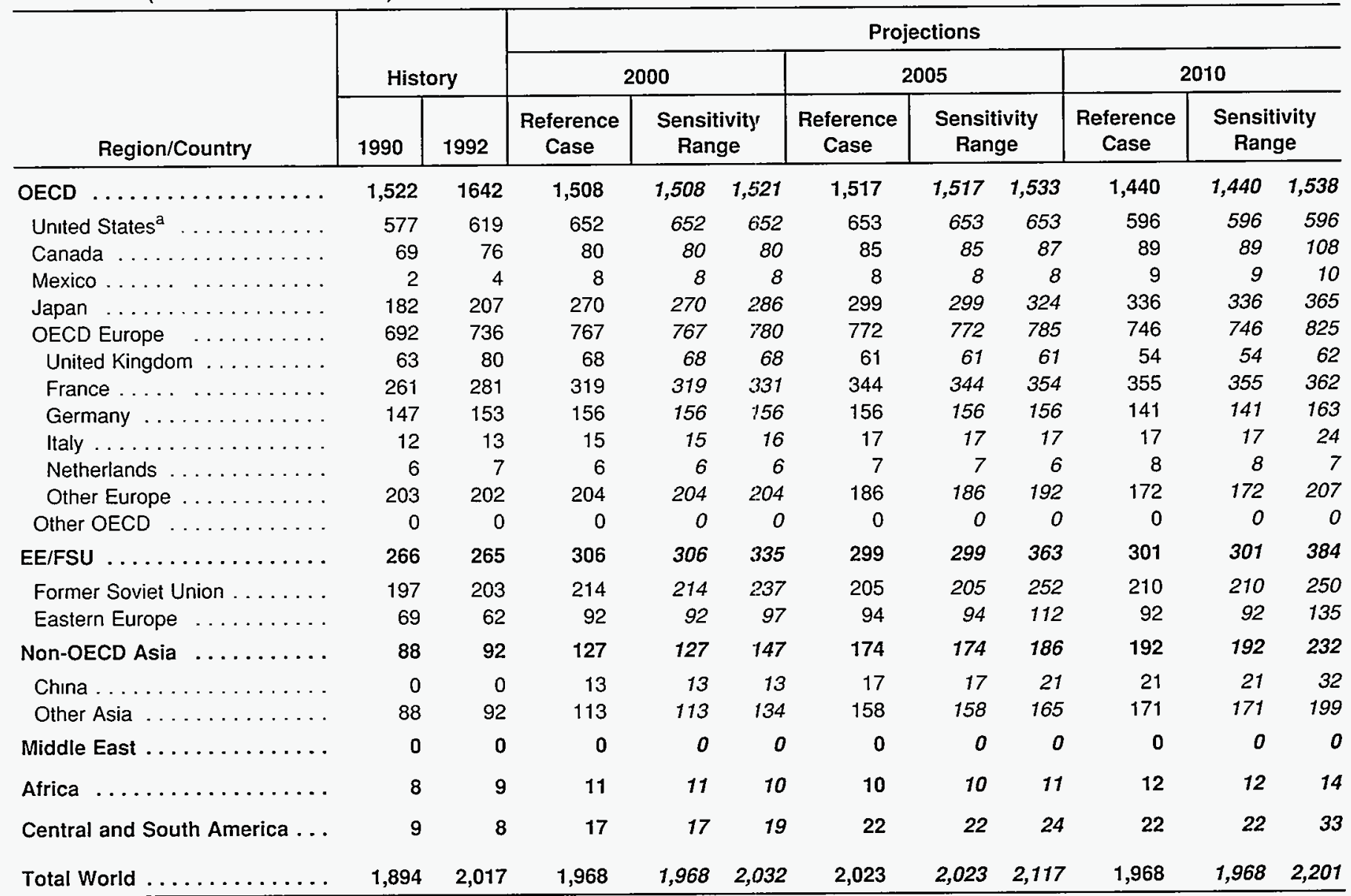

ancludes the 50 States and the District of Columbia. U.S. Territories are included in "Other OECD."

Notes: OECD = Organization for Economic Cooperation and Development. EE/FSU = Eastern Europe/Former Soviet Union. Totals may not equal sum of components due to independent rounding. The electricity portion of the national fuel consumption values consists of generation for domestic use plus an adjustment for electricity trade based on a fuel's share of total generation in the exporting country.

Sources: History: Energy Information Administration (EIA), International Energy Annual 1992, DOE/EIA-0219(92) (Washington, DC, January 1994). Projections: EIA, Annual Energy Outlook 1995, DOE/EIA-0383(95) (Washington, DC, January 1995), Table B8; and World Energy Projection System (1995). 
Table A7. World Consumption of Hydroelectricity and Other Renewable Energy by Region, 1990-2010 (Quadrillion Btu)

\begin{tabular}{|c|c|c|c|c|c|c|c|c|c|c|c|}
\hline \multirow[b]{2}{*}{ Region/Country } & & & \multicolumn{9}{|c|}{ Projections } \\
\hline & 1990 & 1992 & $\begin{array}{l}\text { Reference } \\
\text { Case }\end{array}$ & $\begin{array}{c}\text { Sensitiv } \\
\text { Rang }\end{array}$ & ity & $\begin{array}{l}\text { Reference } \\
\text { Case }\end{array}$ & $\begin{array}{r}\text { Sensiti } \\
\text { Rang }\end{array}$ & $\begin{array}{l}\text { vity } \\
e\end{array}$ & $\begin{array}{l}\text { Reference } \\
\text { Case }\end{array}$ & $\begin{array}{r}\text { Sensi } \\
\text { Ran }\end{array}$ & ity \\
\hline$\ldots \ldots \ldots \ldots \ldots \ldots$ & 15.7 & 16.1 & 19.8 & 18.8 & 20.8 & 21.5 & 20.0 & 23.1 & 24.0 & 21.9 & 26.2 \\
\hline United States $^{\mathrm{a}} \ldots \ldots \ldots \ldots$ & 6.2 & 6.4 & 7.8 & 7.7 & 7.9 & 8.3 & 8.1 & 8.8 & 9.4 & 8.8 & 10.0 \\
\hline Japan $\ldots \ldots \ldots \ldots \ldots$ & 1.0 & 1.0 & 1.8 & 1.1 & 2.4 & 1.9 & 1.0 & 2.6 & 2.0 & 0.8 & 3.0 \\
\hline OECD Europe $\ldots \ldots \ldots \ldots$ & 4.7 & 5.0 & 5.3 & 5.2 & 5.5 & 5.7 & 5.4 & 5.9 & 6.2 & 5.7 & 6.7 \\
\hline United Kingdom . . . . . . . . & 0.1 & 0.1 & 0.2 & 0.1 & 0.2 & 0.2 & 0.1 & 0.2 & 0.2 & 0.1 & 0.3 \\
\hline France $\ldots \ldots \ldots \ldots \ldots$ & 0.5 & 0.7 & 0.7 & 0.7 & 0.7 & 0.7 & 0.7 & 0.7 & 0.7 & 0.7 & 0.8 \\
\hline Germany $\ldots . . \ldots \ldots \ldots$ & 0.4 & 0.3 & 0.3 & 0.3 & 0.3 & 0.4 & 0.3 & 0.4 & 0.4 & 0.3 & 0.5 \\
\hline EE/FSU $\ldots \ldots \ldots \ldots \ldots \ldots$ & 3.0 & 2.8 & 3.1 & 2.9 & 3.3 & 3.4 & 3.1 & 3.3 & 3.8 & 3.3 & 4.4 \\
\hline Former Soviet Union . . . . . . & 2.4 & 2.3 & 2.6 & 2.5 & 2.8 & 2.8 & 2.5 & 3.2 & 2.9 & 2.5 & 3.3 \\
\hline Eastern Europe $\ldots \ldots \ldots \ldots$ & 0.6 & 0.5 & 0.5 & 0.4 & 0.5 & 0.6 & 0.5 & 0.6 & 1.0 & 0.6 & 1.3 \\
\hline Non-OECD Asia $\ldots .$. & 3.1 & 3.2 & 4.8 & 3.3 & 6.3 & 6.0 & 3.8 & 8.6 & 7.5 & 4.4 & 11.1 \\
\hline China ........ & 1.3 & 1.4 & 2.6 & 2.1 & 3.2 & 3.5 & 2.5 & 4.6 & 4.5 & 3.0 & 6.2 \\
\hline Other Asia & 1.8 & 1.8 & 2.1 & 1.2 & 3.1 & 2.6 & 1.3 & 4.0 & 3.0 & 1.4 & 4.9 \\
\hline Middle East $\ldots \ldots \ldots \ldots \ldots$ & 0.1 & 0.1 & 0.3 & 0.2 & 0.4 & 0.4 & 0.2 & 0.6 & 0.4 & 0.1 & 0.8 \\
\hline Africa $\ldots \ldots \ldots \ldots \ldots$ & 0.5 & 0.5 & 0.7 & 0.5 & 0.9 & 0.8 & 0.5 & 1.1 & 0.9 & 0.5 & 1.3 \\
\hline Central and South America ... & 3.8 & 4.0 & 4.0 & 3.6 & 4.4 & 4.2 & 3.7 & 4.8 & 4.4 & 3.7 & 5.2 \\
\hline
\end{tabular}

Includes the 50 States and the District of Columbia. U.S. Territories are included in "Other OECD."

Notes: OECD = Organization for Economic Cooperation and Development. EE/FSU = Eastern Europe/Former Soviet Union. Range values for OECD Europe and the four regional totals are not equal to the sum of the component countries or country groups but consist of the base value adjusted by the quantity: the square root of the sum of the squared deviations of the respective component countries or country groups from their base value. Other totals may not equal sum of components due to independent rounding. The electricity portion of the national fuel consumption values consists of generation for domestic use plus an adjustment for electricity trade based on a fuel's share of total generation in the exporting country.

Sources: History: Energy Information Administration (EIA), International Energy Annual 1992, DOE/EIA-0219(92) (Washington, DC, January 1994). Projections: EIA, Annual Energy Outlook 1995, DOE/EIA-0383(95) (Washington, DC, January 1995), Table B1; and World Energy Projection System (1995). 
Table A8. World Total Net Electricity Consumption by Region, 1990-2010 (Billion Kilowatthours)

\begin{tabular}{|c|c|c|c|c|c|c|c|c|c|c|c|}
\hline \multirow[b]{2}{*}{ Region/Country } & & & \multicolumn{9}{|c|}{ Projections } \\
\hline & 1990 & 1992 & $\begin{array}{l}\text { Reference } \\
\text { Case }\end{array}$ & $\begin{array}{r}\text { Sensi } \\
\text { Ran }\end{array}$ & $\begin{array}{l}\text { tivity } \\
\text { ige }\end{array}$ & $\begin{array}{c}\text { Reference } \\
\text { Case }\end{array}$ & $\begin{array}{c}\text { Sensit } \\
\text { Ran }\end{array}$ & tivity & $\begin{array}{c}\text { Reference } \\
\text { Case }\end{array}$ & $\begin{array}{r}\text { Sensi } \\
\text { Ran }\end{array}$ & tivity \\
\hline OECD $\ldots \ldots \ldots \ldots \ldots \ldots$ & 6,292 & 6,533 & 7,581 & 7,203 & 7,977 & 8,266 & 7,657 & 8,921 & 8,863 & 8,018 & 9,781 \\
\hline United States . . . . . . . . . . & 2,713 & 2,757 & 3,107 & 3,042 & 3,174 & 3,286 & 3,177 & 3,400 & 3,476 & 3,303 & 3,655 \\
\hline Japan $\ldots \ldots \ldots \ldots \ldots$ & 744 & 792 & 946 & 846 & 1,053 & 1,186 & 1,024 & 1,364 & 1,309 & 1,100 & 1,545 \\
\hline OECD Europe $\ldots \ldots \ldots \ldots$ & 2,113 & 2,249 & 2,641 & 2,496 & 2,793 & 2,832 & 2,598 & 3,080 & 3,027 & 2,707 & 3,373 \\
\hline United Kingdom . . . . . . . . & 273 & 298 & 350 & 321 & 381 & 375 & 334 & 421 & 401 & 348 & 460 \\
\hline France $\ldots \ldots \ldots \ldots$ & 327 & 360 & 423 & 399 & 447 & 453 & 415 & 494 & 484 & 432 & 540 \\
\hline Germany ............ & 487 & 520 & 611 & 575 & 648 & 655 & 597 & 717 & 700 & 622 & 784 \\
\hline Italy $\ldots \ldots \ldots \ldots \ldots$ & 225 & 234 & 274 & 258 & 291 & 294 & 268 & 322 & 314 & 280 & 352 \\
\hline Former Soviet Union . . . . . . & 1,488 & 1,437 & 1,493 & 1,439 & 1,550 & 1,573 & 1,485 & 1,666 & 1,630 & 1,499 & 1,769 \\
\hline Eastern Europe $\ldots \ldots \ldots \ldots$ & 418 & 378 & 421 & 394 & 450 & 447 & 405 & 491 & 472 & 416 & 534 \\
\hline Non-OECD Asia $\ldots \ldots \ldots \ldots$ & 1,268 & 1,492 & 2,100 & 1,880 & 2,338 & 2,511 & 2,133 & 2,935 & 2,918 & 2,370 & 3,555 \\
\hline China $\ldots \ldots \ldots \ldots \ldots$ & 562 & 682 & 1,130 & 1,008 & 1,262 & 1,347 & 1,143 & 1,578 & 1,593 & 1,287 & 1,952 \\
\hline Other Asia & 706 & 810 & 971 & 872 & 1,076 & 1,163 & 990 & 1,357 & 1,324 & 1,083 & 1,602 \\
\hline Middle East & 196 & 186 & 237 & 218 & 257 & 269 & 237 & 303 & 293 & 249 & 342 \\
\hline Africa & 285 & 292 & 335 & 313 & 357 & 358 & 323 & 395 & 378 & 330 & 430 \\
\hline Central and South America ... & 444 & 479 & 625 & 579 & 674 & 689 & 611 & 773 & 742 & 634 & 861 \\
\hline Total World & 10,391 & 10,797 & 12,792 & 12,026 & 13,603 & 14,112 & 12,850 & 15,484 & 15,296 & 13,516 & 17,271 \\
\hline
\end{tabular}

Notes: $\mathrm{OECD}=$ Organization for Economic Cooperation and Developmerit. EE/FSU = Eastern Europe/Former Soviet Union. Electricity consumption equals generation plus imports minus exports minus distribution losses.

Sources: History: Derived from Energy Information Administration (EIA), International Energy Annual 1992, DOE/EIA-0219(92) (Washington, DC. January 1994), Table 29. Projections: EIA, Annual Energy Outlook 1995, DOE/EIA-0383(95) (Washington, DC, January 1995), Table B2; and World Energy Projection System (1995). 
Table A9. World Total Carbon Emissions by Region, 1990-2010 (Million Metric Tons)

\begin{tabular}{|c|c|c|c|c|c|c|c|c|c|c|c|}
\hline \multirow[b]{3}{*}{ Region/Country } & & & \multicolumn{9}{|c|}{ Projections } \\
\hline & \multicolumn{2}{|c|}{ History } & \multicolumn{3}{|c|}{2000} & \multicolumn{3}{|c|}{2005} & \multicolumn{3}{|c|}{2010} \\
\hline & 1990 & 1992 & $\begin{array}{c}\text { Reference } \\
\text { Case }\end{array}$ & $\begin{array}{r}\text { Sensi } \\
\text { Ran }\end{array}$ & $\begin{array}{l}\text { ivity } \\
\text { ge }\end{array}$ & $\begin{array}{l}\text { Reference } \\
\text { Case }\end{array}$ & $\begin{array}{r}\text { Sensi } \\
\text { Rar }\end{array}$ & $\begin{array}{l}\text { ivity } \\
\text { ge }\end{array}$ & $\begin{array}{c}\text { Reference } \\
\text { Case }\end{array}$ & $\begin{array}{r}\text { Sensi } \\
\text { Ran }\end{array}$ & $\begin{array}{l}\text { tivity } \\
\text { ge }\end{array}$ \\
\hline OECD $\ldots \ldots \ldots \ldots \ldots \ldots$ & 2,954 & 3,036 & 3,380 & 3,297 & 3,523 & 3,578 & 3,443 & 3,823 & 3,748 & 3,573 & 4,069 \\
\hline United States . & 1,337 & 1,348 & 1,471 & 1,442 & 1,499 & 1,549 & 1,504 & 1,594 & 1,621 & 1,554 & 1,695 \\
\hline Canada $\ldots \ldots \ldots \ldots \ldots$ & 130 & 135 & 157 & 146 & 172 & 163 & 148 & 185 & 168 & 150 & 196 \\
\hline Mexico . . . . . . . . . . & 87 & 92 & 115 & 104 & 129 & 125 & 108 & 149 & 133 & 110 & 169 \\
\hline Japan $\ldots \ldots \ldots \ldots \ldots$ & 312 & 322 & 375 & 331 & 434 & 405 & 334 & 501 & 421 & 334 & 542 \\
\hline OECD Europe . . & 997 & 1,044 & 1,155 & 1,111 & 1,223 & 1,224 & 1,155 & 1,334 & 1,288 & 1,196 & 1,430 \\
\hline United Kingdom . . . . . . . & 164 & 174 & 204 & 187 & 224 & 215 & 191 & 247 & 225 & 195 & 264 \\
\hline France..$\ldots \ldots \ldots \ldots$ & 112 & 120 & 129 & 115 & 147 & 135 & 111 & 164 & 141 & 110 & 181 \\
\hline Germany $\ldots \ldots \ldots \ldots$ & 266 & 255 & 282 & 264 & 306 & 301 & 271 & 340 & 318 & 278 & 370 \\
\hline Italy . . . . & 117 & 120 & 132 & 122 & 146 & 139 & 124 & 160 & 145 & 126 & 171 \\
\hline Netherlands . . . . . . . . & 59 & 62 & 68 & 64 & 73 & 71 & 65 & 79 & 73 & 66 & 82 \\
\hline Other Europe $\ldots \ldots \ldots \ldots$ & 278 & 314 & 339 & 320 & 364 & 362 & 331 & 403 & 385 & 341 & 442 \\
\hline Other OECD $\ldots \ldots \ldots \ldots$ & 92 & 95 & 108 & 102 & 115 & 113 & 105 & 124 & 117 & 107 & 131 \\
\hline EE/FSU $\ldots \ldots \ldots \ldots \ldots \ldots$ & 1,343 & 1,108 & 1,077 & 1,033 & 1,122 & 1,173 & 1,099 & 1,249 & 1,258 & 1,142 & 1,378 \\
\hline Former Soviet Union . . . . . . . & 1,018 & 872 & 810 & 770 & 852 & 890 & 824 & 962 & 968 & 864 & 1,079 \\
\hline Eastern Europe $\ldots . .$. & 325 & 236 & 267 & 249 & 284 & 282 & 255 & 307 & 290 & 250 & 327 \\
\hline Non-OECD Asia $\ldots \ldots \ldots \ldots$ & 1,123 & 1,209 & 1,668 & 1,504 & 1,853 & 1,917 & 1,637 & 2,244 & 2,159 & 1,762 & 2,638 \\
\hline China . . . . . . . . . . & 648 & 678 & 944 & 841 & 1,052 & 1,084 & 915 & 1,271 & 1,237 & 993 & 1,520 \\
\hline Other Asia $\ldots \ldots \ldots \ldots \ldots$ & 475 & 531 & 724 & 658 & 804 & 833 & 715 & 980 & 922 & 758 & 11,31 \\
\hline Middle East $\ldots \ldots \ldots \ldots \ldots$ & 205 & 222 & 273 & 256 & 291 & 302 & 274 & 334 & 329 & 291 & 373 \\
\hline Africa $\ldots \ldots \ldots \ldots \ldots$ & 195 & 217 & 250 & 236 & 266 & 268 & 245 & 297 & 285 & 253 & 326 \\
\hline Central and South America ... & 193 & 199 & 254 & 233 & 279 & 285 & 251 & 328 & 313 & 265 & 373 \\
\hline Total World . & 6,013 & 5,990 & 6,901 & 6,685 & 7,208 & 7,523 & 7,170 & 8,057 & 8,092 & 7,593 & 8,846 \\
\hline
\end{tabular}

Notes: OECD = Organization for Economic Cooperation and Development. EE/FSU = Eastern Europe/Former Soviet Union. The U.S. numbers include carbon emissions attributable to renewable energy sources.

Sources: History: Derived from Energy Information Administration (EIA), International Energy Annual 1992, DOE/EIA-0219(92) (Washington, DC, January 1994). Projections: EIA, Annual Energy Outlook 1995, DOE/EIA-0383(95) (Washington, DC, January 1995), Table B18; and World Energy Projection System (1995). 
Table A10. World Carbon Emissions From Oil Use by Region, 1990-2010 (Million Metric Tons)

\begin{tabular}{|c|c|c|c|c|c|c|c|c|c|c|c|}
\hline \multirow[b]{3}{*}{ Region/Country } & \multirow{2}{*}{\multicolumn{2}{|c|}{ History }} & \multicolumn{9}{|c|}{ Projections } \\
\hline & & & \multicolumn{3}{|c|}{2000} & \multicolumn{3}{|c|}{2005} & \multicolumn{3}{|c|}{2010} \\
\hline & 1990 & 1992 & $\begin{array}{l}\text { Reference } \\
\text { Case }\end{array}$ & $\begin{array}{r}\text { Sensi } \\
\text { Ran }\end{array}$ & $\begin{array}{l}\text { ivity } \\
\text { ge }\end{array}$ & $\begin{array}{l}\text { Reference } \\
\text { Case }\end{array}$ & $\begin{array}{r}\text { Sens } \\
\text { Rar }\end{array}$ & livity & $\begin{array}{l}\text { Reference } \\
\text { Case }\end{array}$ & $\begin{array}{r}\text { Sensi } \\
\text { Ran }\end{array}$ & $\begin{array}{l}\text { ivity } \\
\text { ge }\end{array}$ \\
\hline OECD $\ldots \ldots \ldots \ldots \ldots \ldots$ & 1,505 & 1,548 & 1,690 & 1,663 & 1,782 & 1,784 & 1,740 & 1,946 & 1,849 & 1,784 & 2,064 \\
\hline United States . . . . . . . . & 583 & 583 & 636 & 622 & 661 & 678 & 656 & 727 & 703 & 672 & 770 \\
\hline Canada $\ldots \ldots \ldots \ldots \ldots$ & 67 & 65 & 71 & 70 & 78 & 74 & 71 & 83 & 76 & 72 & 88 \\
\hline$\ldots \ldots \ldots \ldots$ & 71 & 75 & 98 & 96 & 104 & 105 & 101 & 119 & 111 & 104 & 132 \\
\hline Japan ..... & 209 & 222 & 243 & 236 & 264 & 256 & 246 & 293 & 269 & 254 & 319 \\
\hline OECD Europe $\ldots \ldots \ldots \ldots$ & 534 & 563 & 592 & 581 & 630 & 618 & 601 & 678 & 635 & 610 & 710 \\
\hline United Kingdom . . . . . . . & 71 & 73 & 77 & 75 & 82 & 80 & 78 & 88 & 82 & 79 & 92 \\
\hline France ............. & 74 & 79 & 83 & 81 & 88 & 87 & 84 & 95 & 89 & 86 & 100 \\
\hline Germany ........... & 109 & 117 & 123 & 121 & 131 & 128 & 125 & 141 & 132 & 127 & 147 \\
\hline Italy . . . . . . & 79 & 82 & 86 & 84 & 91 & 90 & 87 & 98 & 92 & 88 & 103 \\
\hline Netherlands. & 31 & 32 & 34 & 33 & 36 & 35 & 34 & 38 & 36 & 35 & 40 \\
\hline Other Europe & 170 & 181 & 190 & 186 & 202 & 198 & 193 & 217 & 204 & 196 & 228 \\
\hline Other OECD . & 41 & 41 & 50 & 49 & 52 & 53 & 52 & 57 & 56 & 54 & 62 \\
\hline EE/FSU $\ldots \ldots \ldots \ldots \ldots$ & 426 & 330 & 259 & 256 & 263 & 319 & 307 & 332 & 390 & 365 & 415 \\
\hline $\begin{array}{l}\text { Former Soviet Union } \ldots \ldots \ldots \\
\text { Eastern Europe } \ldots \ldots\end{array}$ & $\begin{array}{r}355 \\
71\end{array}$ & $\begin{array}{r}283 \\
47\end{array}$ & $\begin{array}{r}197 \\
62\end{array}$ & $\begin{array}{r}195 \\
60\end{array}$ & $\begin{array}{r}200 \\
63\end{array}$ & $\begin{array}{r}250 \\
68\end{array}$ & $\begin{array}{r}244 \\
63\end{array}$ & $\begin{array}{r}261 \\
71\end{array}$ & $\begin{array}{r}317 \\
73\end{array}$ & $\begin{array}{r}300 \\
64\end{array}$ & $\begin{array}{r}338 \\
77\end{array}$ \\
\hline Non-OECD Asia & 324 & 378 & 597 & 590 & 6112 & 661 & 648 & 688 & 701 & 684 & 737 \\
\hline Chına .... & 98 & 112 & 158 & 152 & 161 & 166 & 155 & 173 & 171 & 158 & 183 \\
\hline Other Asia & 226 & 265 & 439 & 435 & 454 & 496 & 488 & 521 & 531 & 520 & 564 \\
\hline Middle East $\ldots \ldots \ldots \ldots \ldots$ & 146 & 156 & 189 & 189 & 191 & 209 & 208 & 212 & 230 & 228 & 235 \\
\hline Africa & 88 & 94 & 116 & 115 & 121 & 128 & 126 & 136 & 139 & 136 & 150 \\
\hline Central and South America ... & 142 & 145 & 190 & 188 & 195 & 205 & 203 & 214 & 220 & 216 & 231 \\
\hline Total World & 2,632 & 2,650 & 3,042 & 3,012 & 3,154 & 3,307 & 3,267 & 3,499 & 3,529 & 3,478 & 3,776 \\
\hline
\end{tabular}

Notes: OECD = Organızation for Economic Cooperation and Development. EE/FSU = Eastern Europe/Former Soviet Union.

Sources: History: Derived from Energy Information Administration (ElA), International Energy Annual 1992, DOE/EIA-0219(92) (Washington, DC, January 1994). Projections: EIA, Annual Energy Outlook 1995, DOE/EIA-0383(95) (Washington, DC, January 1995), Table B18; and World Energy Projection System (1995). 
Table A11. World Carbon Emissions From Natural Gas Use by Region, 1990-2010 (Million Metric Tons)

\begin{tabular}{|c|c|c|c|c|c|c|c|c|c|c|c|}
\hline \multirow[b]{2}{*}{ Region/Country } & & & \multicolumn{9}{|c|}{ Projections } \\
\hline & \multirow{2}{*}{$\frac{1990}{499}$} & \multirow{2}{*}{$\frac{1992}{534}$} & \multirow{2}{*}{$\begin{array}{c}\begin{array}{c}\text { Reference } \\
\text { Case }\end{array} \\
656\end{array}$} & \multicolumn{2}{|c|}{$\begin{array}{c}\text { Sensitivity } \\
\text { Range }\end{array}$} & \multirow{2}{*}{$\begin{array}{c}\begin{array}{c}\text { Reference } \\
\text { Case }\end{array} \\
712\end{array}$} & \multicolumn{2}{|c|}{$\begin{array}{l}\text { Sensitivity } \\
\text { Range }\end{array}$} & \multirow{2}{*}{$\begin{array}{c}\begin{array}{c}\text { Reference } \\
\text { Case }\end{array} \\
776\end{array}$} & \multicolumn{2}{|c|}{$\begin{array}{l}\text { Sensitivity } \\
\text { Range }\end{array}$} \\
\hline OECD $\ldots \ldots \ldots \ldots \ldots \ldots$ & & & & 623 & 688 & & 661 & 758 & & 712 & 838 \\
\hline United States & 274 & 287 & 324 & 311 & 334 & 338 & 313 & 351 & 360 & 332 & 379 \\
\hline Japan ............. & 29 & 30 & 45 & 26 & 64 & 50 & 25 & 76 & 53 & 19 & 87 \\
\hline OECD Europe $\ldots \ldots \ldots \ldots$ & 140 & 156 & 221 & 197 & 243 & 253 & 217 & 288 & 288 & 242 & 334 \\
\hline United Kingdom . . . . . . . & 31 & 32 & 58 & 44 & 73 & 68 & 47 & 90 & 75 & 50 & 103 \\
\hline France $\ldots \ldots \ldots \ldots \ldots$ & 15 & 19 & 26 & 16 & 37 & 30 & 12 & 46 & 35 & 12 & 58 \\
\hline Germany ............ & 29 & 35 & 50 & 38 & 61 & 56 & 39 & 72 & 64 & 42 & 85 \\
\hline EE/FSU $\ldots \ldots \ldots \ldots \ldots \ldots$ & 388 & 366 & 423 & 397 & 450 & 459 & 412 & 508 & 484 & 409 & 562 \\
\hline Former Soviet Union . . . . . . . & 338 & 327 & 371 & 347 & 395 & 399 & 355 & 444 & 410 & 341 & 483 \\
\hline Eastern Europe .... & 49 & 39 & 52 & 39 & 65 & 60 & 42 & 80 & 73 & 46 & 101 \\
\hline Non-OECD Asia $\ldots \ldots \ldots \ldots$ & 43 & 52 & 69 & 44 & 95 & 86 & 46 & 129 & 105 & 52 & 166 \\
\hline China..$\ldots \ldots \ldots \ldots$ & 8 & 8 & 19 & 14 & 24 & 21 & 15 & 27 & 25 & 17 & 33 \\
\hline Other Asia $\ldots \ldots \ldots \ldots \ldots$ & 36 & 45 & 50 & 30 & 71 & 65 & 31 & 102 & 80 & 34 & 132 \\
\hline Middle East $\ldots \ldots \ldots \ldots \ldots$ & 55 & 60 & 78 & 62 & 95 & 87 & 61 & 114 & 92 & 58 & 130 \\
\hline Africa $\ldots \ldots \ldots \ldots \ldots$ & 21 & 24 & 27 & 23 & 32 & 31 & 22 & 40 & 34 & 21 & 48 \\
\hline Central and South America ... & 32 & 32 & 36 & 29 & 43 & 45 & 30 & 60 & 54 & 32 & 78 \\
\hline
\end{tabular}

Notes: OECD = Organization for Economic Cooperation and Development. EE/FSU = Eastern Europe/Former Soviet Union.

Sources: History: Derived from Energy Information Administration (EIA), International Energy Annual 1992, DOE/EIA-0219(92) (Washington, DC, January 1994). Projections: EIA, Annual Energy Outlook 1995, DOE/EIA-0383(95) (Washington, DC, January 1995), Table B18; and World Energy Projection System (1995). 
Table A12. World Carbon Emissions From Coal Use by Region, 1990-2010 (Million Metric Tons)

\begin{tabular}{|c|c|c|c|c|c|c|c|c|c|c|c|}
\hline \multirow[b]{2}{*}{ Region/Country } & & & \multicolumn{9}{|c|}{ Projections } \\
\hline & 1990 & 1992 & $\begin{array}{l}\text { Reference } \\
\text { Case }\end{array}$ & $\begin{array}{r}\text { Sensi } \\
\text { Ran }\end{array}$ & $\begin{array}{l}\text { ivity } \\
\text { ge }\end{array}$ & $\begin{array}{c}\text { Reference } \\
\text { Case }\end{array}$ & $\begin{array}{r}\text { Sensit } \\
\text { Ran }\end{array}$ & $\begin{array}{l}\text { ivity } \\
\text { ge }\end{array}$ & $\begin{array}{l}\text { Reference } \\
\text { Case }\end{array}$ & $\begin{array}{r}\text { Sensi } \\
\text { Rar }\end{array}$ & $\begin{array}{l}\text { ivity } \\
\text { ge }\end{array}$ \\
\hline OECD $\ldots \ldots \ldots \ldots \ldots \ldots$ & 950 & 955 & 1,033 & 1,012 & 1,053 & 1,082 & 1,042 & 1,119 & 1,122 & 1,078 & 1,167 \\
\hline United States . . . . . . . . . & 480 & 479 & 511 & 504 & 516 & 533 & 523 & 540 & 557 & 542 & 579 \\
\hline Japan $\ldots \ldots \ldots \ldots \ldots$ & 74 & 69 & 88 & 68 & 106 & 98 & 63 & 132 & 99 & 62 & 135 \\
\hline OECD Europe $\ldots \ldots \ldots \ldots$ & 322 & 326 & 342 & 333 & 350 & 353 & 337 & 369 & 365 & 344 & 386 \\
\hline United Kingdom.$\ldots \ldots \ldots$ & 61 & 70 & 69 & 69 & 70 & 68 & 66 & 69 & 68 & 66 & 69 \\
\hline France $\ldots \ldots \ldots \ldots \ldots$ & 23 & 22 & 20 & 17 & 22 & 19 & 15 & 23 & 17 & 11 & 23 \\
\hline Germany & 127 & 103 & 110 & 105 & 114 & 117 & 107 & 127 & 123 & 109 & 137 \\
\hline Italy ....... & 13 & 13 & 17 & 12 & 21 & 17 & 12 & 21 & 18 & 12 & 23 \\
\hline EE/FSU $\ldots \ldots \ldots \ldots \ldots$ & 529 & 412 & 395 & 381 & 409 & 395 & 380 & 409 & 384 & 368 & 400 \\
\hline Former Soviet Union . . . . . . . & 325 & 262 & 243 & 228 & 258 & 241 & 225 & 257 & 240 & 222 & 257 \\
\hline Eastern Europe .... & 204 & 150 & 153 & 150 & 155 & 154 & 150 & 157 & 144 & 140 & 148 \\
\hline Non-OECD Asia $\ldots \ldots \ldots \ldots$ & 755 & 779 & 1,002 & 869 & 1,146 & 1,170 & 943 & 1,427 & 1,353 & 1,026 & 1,735 \\
\hline Chına...$\ldots \ldots \ldots$ & 542 & 558 & 767 & 675 & 867 & 898 & 745 & 1,071 & 1,041 & 819 & 1,303 \\
\hline Other Asıa . . . . . . . . . . & 213 & 221 & 235 & 193 & 279 & 272 & 195 & 357 & 311 & 204 & 434 \\
\hline Middle East $\ldots \ldots \ldots \ldots \ldots$ & 4 & 5 & 5 & 5 & 6 & 6 & 5 & 8 & 7 & 5 & 9 \\
\hline Africa $\ldots \ldots$ & 85 & 99 & 106 & 98 & 114 & 109 & 97 & 121 & 112 & 96 & 128 \\
\hline Central and South America ... & 19 & 22 & 28 & 16 & 40 & 35 & 17 & 54 & 40 & 18 & 64 \\
\hline Total World . & 2,343 & 2,272 & 2,569 & 2,436 & 2,713 & 2,797 & 2,568 & 3,054 & 3,018 & 2,690 & 3,399 \\
\hline
\end{tabular}

Notes: OECD = Organization for Economic Cooperation and Development. EE/FSU = Eastern Europe/Former Soviet Union.

Sources: History: Derived from Energy Information Administration (EIA), International Energy Annual 1992, DOE/EIA-0219(92) (Washington, DC. January 1994). Projections: EIA, Annual Energy Outlook 1995, DOE/EIA-0383(95) (Washington, DC, January 1995), Table B18; and World Energy Projection System (1995). 
Table A13. World Total Energy Consumption by Region and Fuel, 1990-2010 (Exajoules)

\begin{tabular}{|c|c|c|c|c|c|c|c|c|c|c|c|}
\hline \multirow[b]{3}{*}{ Region/Fuel } & \multirow{2}{*}{\multicolumn{2}{|c|}{ History }} & \multicolumn{9}{|c|}{ Projections } \\
\hline & & & \multicolumn{3}{|c|}{2000} & \multicolumn{3}{|c|}{2005} & \multicolumn{3}{|c|}{2010} \\
\hline & 1990 & 1992 & $\begin{array}{c}\text { Reference } \\
\text { Case }\end{array}$ & $\begin{array}{r}\text { Sensi } \\
\text { Ran }\end{array}$ & $\begin{array}{l}\text { ivity } \\
\text { ge }\end{array}$ & $\begin{array}{c}\text { Reference } \\
\text { Case }\end{array}$ & $\begin{array}{r}\text { Sensit } \\
\text { Ran }\end{array}$ & ivity & $\begin{array}{c}\text { Reference } \\
\text { Case }\end{array}$ & $\begin{array}{r}\text { Sensit } \\
\text { Ran }\end{array}$ & $\begin{array}{l}\text { ivity } \\
\text { ge }\end{array}$ \\
\hline OECD $\ldots \ldots \ldots \ldots \ldots \ldots$ & 193.9 & 200.7 & 226.2 & 217.5 & 235.4 & 239.9 & 226.5 & 254.3 & 252.1 & 234.6 & 271.4 \\
\hline Oil $\ldots \ldots \ldots \ldots \ldots$ & 84.1 & 86.3 & 94.6 & 93.0 & 99.7 & 99.9 & 97.4 & 108.9 & 103.6 & 99.9 & 115.6 \\
\hline Natural Gas . . . . . . . . & 36.8 & 39.6 & 48.2 & 45.7 & 50.5 & 52.2 & 48.5 & 55.6 & 56.9 & 52.2 & 61.4 \\
\hline Coal $\ldots \ldots \ldots \ldots \ldots$ & 39.5 & 39.5 & 42.8 & 41.9 & 43.6 & 44.8 & 43.2 & 46.3 & 46.5 & 44.6 & 48.3 \\
\hline Nuclear $\ldots \ldots \ldots \ldots \ldots$ & 17.0 & 18.4 & 19.8 & 19.8 & 20.0 & 20.2 & 20.2 & 20.4 & 19.8 & 19.8 & 21.1 \\
\hline Renewables .......... & 16.6 & 17.0 & 20.9 & 19.8 & 21.9 & 22.7 & 21.1 & 24.4 & 25.4 & 23.1 & 27.6 \\
\hline EE/FSU $\ldots \ldots \ldots \ldots \ldots \ldots$ & 78.4 & 66.7 & 67.2 & 64.7 & 69.9 & 73.3 & 68.7 & 78.1 & 78.8 & 71.8 & 86.2 \\
\hline Oil $\ldots \ldots \ldots \ldots \ldots \ldots$ & 22.1 & 17.1 & 13.5 & 13.3 & 13.7 & 16.6 & 16.0 & 17.3 & 20.3 & 19.0 & 21.6 \\
\hline Natural Gas . . . . . . . . & 28.1 & 26.5 & 30.7 & 28.8 & 32.7 & 33.3 & 29.9 & 36.9 & 35.1 & 29.7 & 40.8 \\
\hline Coal $\ldots \ldots \ldots \ldots \ldots$ & 21.8 & 17.0 & 16.3 & 15.7 & 16.8 & 16.3 & 15.7 & 16.9 & 15.8 & 15.2 & 16.5 \\
\hline Nuclear $\ldots \ldots \ldots \ldots \ldots$ & 3.2 & 3.1 & 3.6 & 3.6 & 3.9 & 3.5 & 3.5 & 4.2 & 3.5 & 3.5 & 4.5 \\
\hline$\ldots \ldots \ldots \ldots$ & 3.1 & 3.0 & 3.3 & 3.1 & 3.4 & 3.6 & 3.3 & 3.4 & 4.1 & 3.5 & 4.6 \\
\hline Non-OECD Asia $\ldots \ldots \ldots \ldots$ & 55.4 & 59.9 & 83.8 & 75.0 & 93.2 & 97.2 & 82.6 & 113.6 & 110.0 & 89.4 & 133.9 \\
\hline Oil $\ldots \ldots \ldots \ldots \ldots \ldots$ & 16.9 & 19.7 & 31.1 & 30.7 & 31.9 & 34.5 & 33.8 & 35.8 & 36.6 & 35.7 & 38.4 \\
\hline Natural Gas ............ & 3.2 & 3.8 & 5.0 & 3.2 & 6.9 & 6.2 & 3.4 & 9.4 & 7.6 & 3.7 & 12.0 \\
\hline Coal $\ldots \ldots \ldots \ldots \ldots$ & 31.1 & 32.1 & 41.3 & 35.8 & 47.2 & 48.2 & 38.8 & 58.8 & 55.7 & 42.2 & 71.5 \\
\hline Nuclear $\ldots \ldots \ldots \ldots \ldots$ & 1.0 & 1.0 & 1.4 & 1.4 & 1.6 & 1.9 & 1.9 & 2.0 & 2.1 & 2.1 & 2.5 \\
\hline Renewables $\ldots \ldots \ldots \ldots$ & 3.3 & 3.3 & 5.0 & 3.5 & 6.7 & 6.4 & 4.0 & 9.0 & 8.0 & 4.7 & 11.7 \\
\hline Middle East $\ldots \ldots \ldots \ldots \ldots$ & 11.9 & 12.9 & 16.1 & 14.8 & 17.4 & 17.9 & 15.8 & 20.2 & 19.5 & 16.5 & 22.7 \\
\hline Oil $\ldots \ldots \ldots \ldots \ldots$ & 7.7 & 8.2 & 9.9 & 9.9 & 10.0 & 10.9 & 10.9 & 11.1 & 12.0 & 11.9 & 12.3 \\
\hline Natural Gas ............ & 4.0 & 4.4 & 5.6 & 4.5 & 6.9 & 6.3 & 4.5 & 8.3 & 6.7 & 4.2 & 9.5 \\
\hline Coal $\ldots \ldots \ldots \ldots \ldots$ & 0.2 & 0.2 & 0.2 & 0.2 & 0.2 & 0.3 & 0.2 & 0.3 & 0.3 & 0.2 & 0.4 \\
\hline Nuclear $\ldots \ldots \ldots \ldots \ldots$ & 0.0 & 0.0 & 0.0 & 0.0 & 0.0 & 0.0 & 0.0 & 0.0 & 0.0 & 0.0 & 0.0 \\
\hline Renewables $\ldots \ldots \ldots \ldots$ & 0.1 & 0.2 & 0.3 & 0.2 & 0.4 & 0.4 & 0.2 & 0.7 & 0.5 & 0.1 & 0.9 \\
\hline Africa $\ldots \ldots \ldots \ldots \ldots \ldots$ & 10.3 & 11.4 & 13.3 & 12.4 & 14.2 & 14.4 & 13.0 & 15.9 & 15.4 & 13.4 & 17.5 \\
\hline Oil $\ldots \ldots \ldots \ldots \ldots$ & 4.6 & 4.9 & 6.1 & 6.0 & 6.3 & 6.7 & 6.6 & 7.1 & 7.3 & 7.1 & 7.8 \\
\hline Natural Gas . . . . . . . . & 1.5 & 1.7 & 2.0 & 1.7 & 2.3 & 2.3 & 1.6 & 2.9 & 2.5 & 1.5 & 3.5 \\
\hline Coal $\ldots \ldots \ldots \ldots \ldots$ & 3.5 & 4.1 & 4.4 & 4.0 & 4.7 & 4.5 & 4.0 & 5.0 & 4.6 & 4.0 & 5.3 \\
\hline Nuclear $\ldots \ldots \ldots \ldots \ldots$ & 0.1 & 0.1 & 0.1 & 0.1 & 0.1 & 0.1 & 0.1 & 0.1 & 0.1 & 0.1 & 0.1 \\
\hline Renewables $\ldots \ldots \ldots \ldots$ & 0.6 & 0.6 & 0.8 & 0.5 & 1.0 & 0.8 & 0.5 & 1.2 & 0.9 & 0.5 & 1.4 \\
\hline Central and South America... & 14.7 & 15.2 & 18.2 & 16.8 & 19.6 & 20.2 & 17.9 & 22.7 & 22.0 & 18.8 & 25.5 \\
\hline Oil .............. & 7.4 & 7.6 & 10.0 & 9.9 & 10.3 & 10.8 & 10.7 & 11.2 & 11.5 & 11.3 & 12.1 \\
\hline Natural Gas ........... & 2.3 & 2.4 & 2.6 & 2.1 & 3.1 & 3.2 & 2.2 & 4.3 & 3.9 & 2.3 & 5.7 \\
\hline Coal $\ldots \ldots \ldots \ldots \ldots$ & 0.8 & 0.9 & 1.2 & 0.7 & 1.7 & 1.4 & 0.7 & 2.2 & 1.7 & 0.7 & 2.6 \\
\hline Nuclear $\ldots \ldots \ldots \ldots \ldots$ & 0.1 & 0.1 & 0.2 & 0.2 & 0.2 & 0.3 & 0.3 & 0.3 & 0.3 & 0.3 & 0.4 \\
\hline Renewables $\ldots \ldots \ldots \ldots$ & 4.0 & 4.2 & 4.2 & 3.8 & 4.6 & 4.5 & 3.9 & 5.1 & 4.6 & 3.9 & 5.4 \\
\hline World Total $\ldots \ldots \ldots \ldots$ & 364.6 & 366.7 & 424.8 & 402.5 & 448.3 & 462.8 & 425.5 & 503.3 & 497.7 & 445.7 & 555.6 \\
\hline Oil $\ldots \ldots \ldots \ldots \ldots$ & 142.8 & 143.8 & 165.1 & 163.5 & 171.2 & 179.3 & 177.2 & 189.7 & 191.3 & 188.5 & 204.6 \\
\hline Natural Gas . . . . . . . . & 76.0 & 78.4 & 94.1 & 90.3 & 97.9 & 103.5 & 97.3 & 109.8 & 112.7 & 103.9 & 121.8 \\
\hline Coal $\ldots \ldots \ldots \ldots \ldots$ & 96.9 & 93.8 & 106.1 & 100.6 & 112.0 & 115.5 & 106.0 & 126.1 & 124.6 & 111.0 & 140.3 \\
\hline Nuclear $\ldots \ldots \ldots \ldots \ldots$ & 21.4 & 22.7 & 25.0 & 25.0 & 25.9 & 26.0 & 26.0 & 27.2 & 25.7 & 25.7 & 28.8 \\
\hline Renewables . . . . . . . . . & 27.6 & 28.3 & 29.7 & 28.0 & 31.4 & 38.4 & 35.5 & 41.6 & 43.4 & 39.2 & 48.0 \\
\hline
\end{tabular}

Notes: OECD = Organization for Economic Cooperation and Development. EE/FSU = Eastern Europe/Former Soviet Union. Energy totals include consumption of biofuels in the United States. All sensitivity ranges are derived independently and do not necessarily add to totals. Other totals may not equal sum of components due to independent rounding. The electricity portion of the national fuel consumption values consists of generation for domestic use plus an adjustment for electricity trade based on a fuel's share of total generation in the exporting country.

Sources: History: Energy Information Administration (EIA), International Energy Annual 1992, DOE/EIA-0219(92) (Washington, DC, January 1994). Projections: EIA, World Energy Projection System (1995). 
Table A14. World Total Energy Consumption by Region, 1990-2010 (Exajoules)

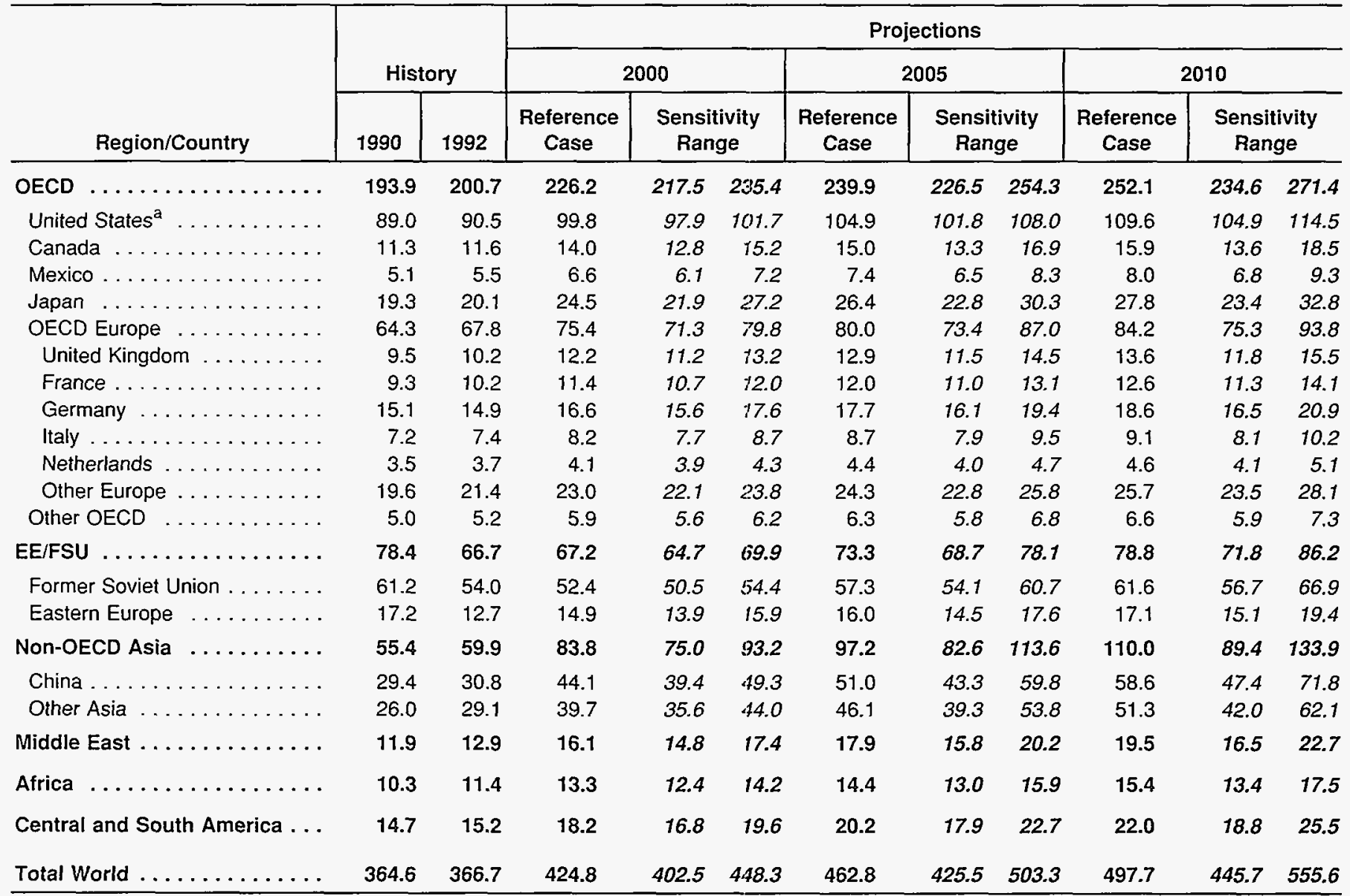

ancludes the 50 States and the District of Columbia. U.S. Territories are included in "Other OECD."

Notes: OECD = Organization for Economic Cooperation and Development. EE/FSU = Eastern Europe/Former Soviet Union. Energy totals Include consumption of biofuels in the United States. All sensitivity ranges are derived independently and do not necessarily add to totals. Other totals may not equal sum of components due to independent rounding. The electricity portion of the national fuel consumption values consists of generation for domestic use plus an adjustment for electricity trade based on a fuel's share of total generation in the exporting country.

Sources: History: Energy Information Administration (EIA), International Energy Annual 1992, DOE/EIA-0219(92) (Washington, DC, January 1994). Projections: EIA, Annual Energy Outlook 1995, DOE/EIA-0383(95) (Washington, DC, January 1995), Table B1; and World Energy Projection System (1995). 


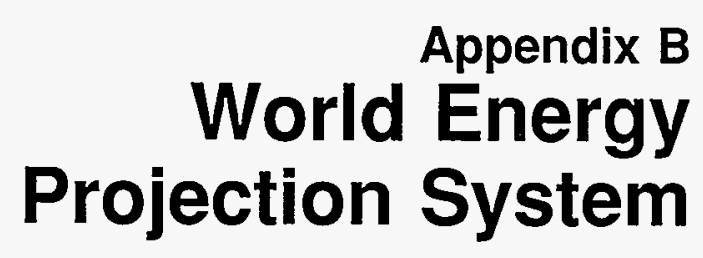




\section{World Energy Projection System}

The projections of world energy consumption published annually by the Energy Information Administration (EIA) in the International Energy Outlook (IEO) are derived from the World Energy Projection System (WEPS). WEPS is an integrated set of personal-computer-based spreadsheets containing data compilations, assumption specifications, descriptive analysis procedures, and projection models. The WEPS accounting framework incorporates projections from independently documented models and assumptions about the future energy intensity of economic activity (ratios of total energy consumption divided by gross domestic product [GDP]) and about the rate of incremental energy requirements met by natural gas, coal, and renewable energy sources (hydroelectricity, geothermal, solar, wind, biomass, and other renewable sources).

WEPS provides projections of total world primary energy consumption, as well as projections of energy consumption by primary energy type (oil, natural gas, coal, nuclear, and hydroelectric and other renewable resources), and projections of net electricity consumption. Carbon emissions resulting from fossil fuel use are derived from the energy consumption projections. All projections are computed in 5-year intervals through the year 2010. For both historical series and projection series, WEPS provides analytical computations of energy intensity and energy elasticity (the percentage change in energy consumption per percentage change in GDP).

WEPS projections are provided for regions and selected countries. Projections are made for 10 individual countries, 9 of which-United States, Canada, Mexico, Japan, United Kingdom, France, Germany, Italy, and the Netherlands-are members of the Organization for Economic Cooperation and Development (OECD). China is the only non-OECD country for which individual projections are made. Beyond these individual countries, the rest of the world is divided into regions. Regions in the OECD include North America (Canada, Mexico, and the United States), Europe (France, Germany, Italy, Netherlands, United Kingdom, and Other Europe), and Pacific (Japan and Other OECD, which includes Australia, New Zealand, and the U.S. Territories). Regions in the non-OECD grouping include
Eastern Europe (EE), the former Soviet Union (FSU), non-OECD Asia (China and Other Asia), Middle East, Africa, and Central and South America.

The process of creating the projections begins with the calculation of a Reference Case total energy consumption projection for each country or region for each 5year interval in the forecast period. The total energy consumption projection for each forecast year is the product of an assumed GDP growth rate, an assumed energy elasticity, and the total energy consumption for the prior forecast year. For the first year of the forecast, the prior year consumption is based on historical data. Subsequent calculations are based on the energy consumption projections for the preceding years.

Projections of world oil supply are provided to WEPS from EIA's International Energy Module, which is a submodule of the National Energy Modeling System (NEMS). Projections of world nuclear energy consumption are derived from nuclear power electricity generation projections from EIA's International Nuclear Model (INM), PC Version (PC-INM). All U.S. projections are taken from EIA's Annual Energy Outlook (AEO).

A full description of the WEPS is provided in a model documentation report: Energy Information Administration, World Energy Projection System Model Documentation, DOE/EIA-M050(92) (Washington, DC, June 1992). The report presents a thorough description of each of the spreadsheets associated with the WEPS, along with descriptions of the methodologies and assumptions used to produce the projections. It is available from the National Energy Information Center (202/586-8800).

The WEPS is archived annually after publication of the IEO. The IEO95 WEPS archive package will be available for purchase from the National Technical Information Service (703/487-4650) in summer 1995. The archive package will allow users to replicate the projections that appear in IEO95. It is coded in Lotus 1-2-3, Version 2.2, and can be executed on any IBM-compatible personal computer. The package requires about 3 megabytes of hard disk space and about 640 kilobytes of random access memory (RAM). 